UNIVERSIDADE DE SÃO PAULO

FACULDADE DE FILOSOFIA, LETRAS E CIÊNCIAS HUMANAS

DEPARTAMENTO DE LETRAS CLÁSSICAS E VERNÁCULAS

PROGRAMA DE PÓS-GRADUAÇÃO EM LITERATURA

PORTUGUESA

De bordadeira a escritora: a construção da identidade feminina nos quatro primeiros romances de Lídia Jorge

Elisangela Fátima Nogueira Godêncio

Versão Corrigida

São Paulo

2015 
UNIVERSIDADE DE SÃO PAULO

FACULDADE DE FILOSOFIA, LETRAS E CIÊNCIAS HUMANAS

DEPARTAMENTO DE LETRAS CLÁSSICAS E VERNÁCULAS

PROGRAMA DE PÓS-GRADUAÇÃO EM LITERATURA

PORTUGUESA

\title{
De bordadeira a escritora: a construção da identidade feminina nos quatro primeiros romances de Lídia Jorge
}

Elisangela Fátima Nogueira Godêncio

\begin{abstract}
Tese apresentada ao Programa de Pós-Graduação em Literatura Portuguesa, do Departamento de Letras Clássicas e Vernáculas da Faculdade de Filosofia, Letras e Ciências Humanas da Universidade de São Paulo, para obtenção do título de Doutor em Letras.
\end{abstract}

Orientadora: Prof ${ }^{\mathrm{a}}$. Dr ${ }^{\mathrm{a}}$. Marlise Vaz Bridi

Versão Corrigida

São Paulo

2015 
O que reside atrás de nós e o que reside à nossa frente são de minúscula importância comparados ao que reside dentro de nós.

Oliver Wendell Holmes

A verdadeira profissão do homem é encontrar seu caminho para si mesmo.

Hermann Hesse 
A minha querida mãe Luzia, sempre disposta em ajudar e companheira de todas as horas; ao meu marido Rogério e ao meu filho Luís Fernando pela cooperação, paciência e compreensão. Alicerces de minha vida! 


\section{Agradecimentos}

A Deus por dar-me força, coragem e determinação para persistir sempre.

À Prof ${ }^{\mathrm{a}}$. Dr ${ }^{\mathrm{a}}$. Lilian Lopondo (in memoriam), por todos os seus ensinamentos que contribuíram para despertar em mim a paixão pelo estudo da literatura.

Às professoras que compuseram a Banca de Qualificação, Prof ${ }^{a}$. Dr ${ }^{a}$. Flávia Maria Ferraz Sampaio Corradin e Prof ${ }^{a}$. Dr ${ }^{a}$. Susana Ramos Ventura, pelas valiosas contribuições.

Ao Geraldo Barbosa, grande amigo, por estar sempre pronto a, de alguma forma, cooperar.

Ao Cristiano Miranda, amigo querido, pela colaboração, apoio e frequentes palavras de estímulo.

Àqueles que, compreendendo a necessidade da ausência, esperaram pelo retorno. 
Agradeço especialmente à $\operatorname{Prof}^{\mathrm{a}}$. Dr ${ }^{\mathrm{a}}$. Marlise Vaz Bridi, minha orientadora, exemplo de profissionalismo e competência; presença fundamental e sempre estimuladora para o desenvolvimento deste estudo e para minha formação acadêmica; símbolo de dedicação e amizade. 


\section{RESUMO}

Este trabalho constitui um estudo a cerca da construção da identidade feminina tal como se apresenta nos quatro primeiros romances da autora portuguesa Lídia Jorge. Para tanto, foram selecionadas as seguintes obras: O Dia dos Prodígios (1980), O cais das merendas (1982), Notícia da Cidade Silvestre (1984) e A Costa dos murmúrios (1988). A análise dessas obras busca revelar a trajetória percorrida pelas personagens femininas nos romances, observando seus comportamentos, suas angústias, seus medos e suas paixões, para que se possa examinar como se processa a construção identitária da mulher que se insere na época ditatorial vivida por Portugal (como no primeiro romance) e daquelas que vivem no contexto pós-Revolução de 74 (como as mulheres dos outros três romances). Propõe-se identificar, neste estudo, de que maneira se desenvolve a busca do autoconhecimento das personagens, no sentido de, pelo menos, se investigar como se inicia o processo de construção da identidade da mulher portuguesa, que ficou esquecida no período que antecedeu e marcou a experiência de Abril de 1974 (destacada na obra $O$ dia dos prodígios); como ocorre a busca pelo autoconhecimento no contexto de colonização cultural que Portugal vive nos tempos subsequentes ao 25 de Abril de 1974 (como se vê em $O$ cais das merendas); como se processa a luta da mulher pela sobrevivência na Lisboa do final dos anos setenta (destacada em Notícia da cidade silvestre); e de que modo se desenvolve a ação entre os finais dos anos sessenta e princípio dos anos setenta, em pleno ambiente de Guerra Colonial (tal como é ficcionalizado no romance A Costa dos Murmúrios). Estas obras representam uma incursão pela vida das mulheres portuguesas da segunda metade do século XX. Esta investigação se desenvolve por meio da observação detalhada de personagens femininas que buscavam um lugar seu, um espaço próprio, tentando revelar e compreender o mundo.

Palavras-chave: Lídia Jorge, identidade feminina, autoconhecimento, interação. 


\section{ABSTRACT}

This thesis is a study about how female identity has been built up in the first four novels written by the Portuguese woman writer Lídia Jorge. So, O Dia dos Prodígios (1980), O cais das merendas (1982), Notícia da Cidade Silvestre (1984) and A Costa dos murmúrios (1988) form the corpus of this study. Analysing such works searches to reveal the route covered by the female characters in such novels, having in view their behaviours, anguishes, fears and passions, in order that, by such means, one can examine the way of construction of identity of women during Salazar dictatorship, as it can be seen in the first novel, as opposed to the identity of those women living after 1974 April Revolution, as shown in the other novels of this corpus. Thus, this work aims at identifying the manner in which the search for self-knowledge happens and develops in each female character, in the sense that one can at least investigate the beginning of Portuguese woman's identitary construction process (this woman remained forgotten and apart from Portuguese society before and shortly after Carnation Revolution, experience which has been detached in the first novel, $O$ dia dos prodígios. Another aim of this study is to investigate women's search for self-knowledge in the context of cultural colonization experienced by Portugal in the years ahead of April 74 (as it is shown in the second work, $O$ cais das merendas) and also the struggle for woman's survival in the Lisbon after the seventies (shown in Notícia da cidade silvestre) and finally the way the action occurs in the period between the final years of the sixties and the first years of the seventies, when the Colonial War was taking place (as it is fictionalized in A costa dos murmúrios). Such works represent an incursion into the Portuguese women's lives in the second half of the $20^{\text {th }}$ century. This investigation is developed by means of a detailed observation of female characters who searched for a place for themselves in the world an also ried to reveal and understand the world around them.

Key-words: Lídia Jorge, female identity; self-knowledge; interaction. 


\section{SUMÁRIO}

INTRODUÇÃO 10

CAPÍTULO I - O DIA DOS PRODÍGIOS: IDENTIDADE (FEMININA)

GERMINAL 30

CAPÍTULO II -A BUSCA DA IDENTIDADE PERDIDA EM $O$ CAIS DAS MERENDAS

2.1 - O percurso identitário das personagens 82

2.2 - Da Redonda a Devícias: momento de transição. 86

2.3 - Sebastião Guerreiro: a representação masculina 98

2.4 - Rosária: o sentimento de "não-pertencer" 102

CAPÍTULO III - A PERMANÊNCIA NA IMPERMANÊNCIA: A CONSTRUÇÃO DA IDENTIDADE FEMININA EM NOTÍCIA DA CIDADE SILVESTRE

CAPÍTULO IV - A COSTA DOS MURMÚRIOS: VESTÍGIOS DE GUERRA E CONSTRUÇÃO DA IDENTIDADE FEMININA ............................................... 148

CONSIDERAÇÕES FINAIS ......................................................................... 182

OBRAS DE LÍDIA JORGE .......................................................................... 196

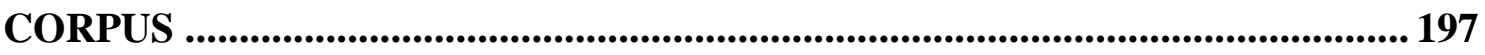

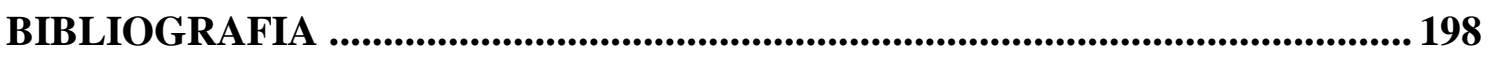


INTRODUÇÃO 
Pela relevância desde o surgimento, em 1980, a obra de Lídia Jorge vem ocupando lugar de merecido destaque por parte da crítica e do público leitor: ao apresentar as vivências de diferentes gerações em cenários ora rurais, ora urbanos, a autora dá voz a uma pluralidade de perspectivas, além de, ao mesmo tempo, tecer uma reflexão sobre os desafios que afetam os vários setores da sociedade portuguesa contemporânea.

De fato, a capacidade da autora de renovar a sua escrita ficcional de obra para obra, quer em termos temáticos, quer também em termos de propostas estruturais sempre inovadoras, permite situá-la entre as mais significativas ficcionistas surgidas em Portugal a partir do último quartel do século XX. Prova disso são os muitos prêmios que lhe vêm sendo concedidos ao longo de seu percurso como ficcionista: $O$ cais das merendas, seu segundo romance, datado de 1982, e, posteriormente, Notícia da cidade silvestre, de 1984, mereceram ambos o Prêmio Literário de Lisboa. Embora $O$ dia dos prodígios, o primeiro romance, de 1980, não tenha sido galardoado com nenhum prêmio, a crítica de imediato o consagrou. Isso se deve às inovações formais no tratamento de um tema complexo como o que discutiu: a condição de atraso a que a administração ditatorial de Salazar havia relegado a sociedade e a cultura portuguesas como um todo. Os temas retratados no primeiro romance acabam iluminando especialmente a condição da mulher, cuja identidade, como se pode ver ao longo da narrativa, existe apenas em seu estado latente (e em apenas algumas personagens, como as duas Carminhas, Branca Volante e, de certa forma, Macário) ou, dito de outro modo, em estado de "desejo".

Por ocasião do $30^{\circ}$ aniversário da publicação de $O$ dia dos prodígios e comemorando o agraciamento da escritora Lídia Jorge com o título de Doutora Honoris Causa pela Universidade do Algarve, o ensaísta Eduardo Lourenço, na conferência de abertura proferida em Loulé, entre outras distinções feitas a Lídia Jorge enquanto escritora, diz o seguinte acerca de $O$ dia dos Prodígios:

... a escritora [Lídia Jorge] adquiriu uma dimensão universal logo a partir da publicação da sua primeira obra - O Dia dos Prodígios. Um livro de grande criação de escrita, uma visão das coisas que passa através de um conhecimento quase físico das palavras, das vivências, 
dos comportamentos, inclusive da maneira de se exprimir de uma província [Algarve], esta em que estamos. ${ }^{1}$

As afirmações feitas por Lourenço ao remeter-se à obra em si mesma revelam uma avaliação que parece desconsiderar o tempo da recepção, mas, em seguida, o ensaísta ressalta a atualidade de $O$ dia dos prodígios:

Não há nada que tenha envelhecido. Das estórias que se conta da aldeia - Vilamaninhos - descobre-se uma maneira poética e ao mesmo tempo emocionada e emocionante de anunciar a chegada da liberdade, com o 25 de Abril. ${ }^{2}$

Em resposta aos elogios feitos pelo crítico, a amiga e escritora acrescenta a sua visão da escritura da obra: "Tenho a ideia que este livro não foi escrito por mim, foi escrito por uma espécie de multidão anónima da qual eu fui uma espécie de transmissor involuntário". ${ }^{3}$

Na obra de Lídia Jorge, encontram-se ressonâncias de sua história de vida, de sua visão de mundo e da sua vivência, desde o Algarve, lugar em que nasceu e que é o espaço da primeira obra $O$ dia dos prodígios, até as colônias de Moçambique e Angola, para onde acompanhou o marido no período da guerra, até, finalmente, o período em que se fixou em Portugal, onde, inclusive, exerceu a função de professora. $O$ experimentalismo linguístico que permeia o conjunto de sua obra também traz ecos dos autores que leu durante seu percurso de vida, valem destacar: Dostoiévski, Faulkner, Virgínia Woolf, T. S. Elliot.

Já na segunda metade do século $\mathrm{XX}$ - e antes de seu surgimento no cenário literário - se dá, em território lusitano, uma irrupção de mulheres escritoras, com um conjunto de obras importantes, não apenas pela quantidade como também pela qualidade. De fato, apesar de, sobretudo nos séculos XVIII e XIX, já existirem, no campo da narrativa de ficção, algumas obras de autoria feminina, foi somente no século passado, especialmente a partir dos anos 50, que a narrativa ficcional feminina emergiu como algo particularmente significativo. A escrita, nesse contexto, ganha contornos que transcendem o que se considera o escrever como somente o que se faz sobre o papel.

\footnotetext{
${ }^{1}$ Palavras de Eduardo Lourenço por ocasião da abertura do ciclo de conferências em torno da primeira obra de Lídia Jorge. Disponível em: http://www.ipsilon.publico.pt/cultura/noticia/universidade-doalgarve-homenageia-lidia-jorge-1470941 Acessado em 31 de julho de 2013.

${ }^{2}$ Ibidem.

${ }^{3}$ Ibidem.
} 
Maria Alzira Seixo afirma que esse conceito de escrita pode estender-se a tudo o que, "sendo ação, se inscreve no meu papel social, no meu estar no mundo." 4

Segundo ela, a referência à escrita feminina não se resume àquilo que está diretamente ligado ao ato de escrever (transpor palavras para o papel). Essas palavras, pelo que se nota, estão carregadas de significado. Desse modo, o que acaba refletindo-se no texto é a alma feminina. Embora o conceito de escrita proposto por Seixo possa ser enquadrado em textos produzidos por homens ou mulheres, ele acaba se adequando melhor à escrita de autoria feminina. Isso ocorre porque, ao praticar o ato de escrever, a mulher acaba externando aquilo que antes pertencia exclusivamente a um universo muito íntimo, ao privado. Ao que tudo indica, por meio da linguagem utilizada nesse contexto (a oralidade, os monólogos, os diálogos banais), é que se compõem as marcas dos textos de autoria feminina. O domínio desse campo de conhecimento dá às mulheres a vantagem da particularização da escrita feminina, pois se trata de um ambiente que lhe é familiar - mais do que isso, é o espaço de sua vivência.

Vale ressaltar que se trata aqui de verificar que a hipótese de a escrita produzida por mulheres apresenta, sob a perspectiva da crítica Isabel Magalhães 5 , "qualidades" (em sentido neutro) próprias, tão diversificadas quanto as que se encontram em narrativas escritas por homens. Isso mostra que em textos literários de autoria feminina existem, simultaneamente, alguns traços que se pretendem universais (ou seja, que discutem temas comuns às narrativas de autoria feminina e masculina), e outros que se revelam específicos do contexto feminino por inscreverem elementos referentes à opressão e repressão das mulheres e sua reação a elas. Nesse sentido, as críticas Castelo Branco e Brandão concordam que as narrativas produzidas por mulheres constroem-se em torno de minúcias, de banalidades, de desvios, de multiplicação de sentidos minúsculos (do corpo, do gozo, das paixões). ${ }^{6}$

Cria-se, pelo que se percebe, um estilo diferenciado de escrita (com características físicas, culturais e psíquicas), um discurso próprio que pretende questionar, de certa forma, os lugares das mulheres na sociedade. São essas especificidades apresentadas no texto que se mostram relevantes para se classificar um texto como escrita feminina. Acredita-se que o gênero do autor (masculino ou feminino)

\footnotetext{
${ }^{4}$ SEIXO, Maria Alzira. Discursos do texto. Portugal: Livraria Bertrand, 1977.

${ }^{5}$ MAGALHÃES, Isabel Allegro de. O sexo dos textos: traços da ficção narrativa de autoria feminina. Lisboa: Caminho, 1995, p. 17.

${ }^{6}$ CASTELO BRANCO, Lúcia \& BRANDÃO, Ruth Silviano. A mulher escrita. Rio de Janeiro: Lamparina, 2004.
} 
não é o que realmente importa, mas sim os temas discutidos no texto. É provável que um texto de autoria feminina tenha maior tendência a apresentar em seu corpo temas que se enquadram com mais intensidade no cotidiano feminino. Isso se constata naquelas narrativas nas quais as experiências vividas pelas autoras constituem o principal suporte para os textos, o que, evidentemente, não se pode tomar como regra, mas apenas como uma tendência.

Destaque-se que, ao se enfatizarem os aspectos inerentes à criação literária produzida pelas mulheres e os valores femininos aí expressos, não se pretende identificar uma especificidade restrita a esse grupo; para tanto, tornar-se-ia necessário evocar textos de autoria masculina com traços idênticos. Interessa, então, detectar

\begin{abstract}
características que possam ser reconhecidas como predominantemente femininas pela sua sintonia com dominantes da vida das mulheres [...] identificar indicadores de uma outra sensibilidade, de uma outra percepção do real, de uma outra lógica, expressos literariamente nos textos e afins à experiência das mulheres: à sua experiência corporal, interior, social, cultural. Mas é claro que estas não possuem em exclusivo esses elementos: muitos homens comungam deles também. [...] Poderemos é eventualmente falar de um sexo dos textos, ou seja, falar de tendências predominantes na escrita. ${ }^{7}$
\end{abstract}

Essas tendências predominantes na escrita feminina, esse "modo feminino" de narrar parece remeter a um autoconhecimento e, consequentemente, à busca de uma identidade que talvez pudesse estar preservada em um universo antes considerado exclusivamente de dentro, mas que agora pode vir a público. Nessa direção, a publicação das Novas Cartas Portuguesas, em 1972, adquire dupla relevância: se, por um lado, configura-se como um marco na trajetória das autoras portuguesas, por outro, ilustra bem essa nova categoria de textos, cuja temática extrapola a categoria de "privado".

O texto, escrito por Maria Isabel Barreno, Maria Teresa Horta e Maria Velho da Costa, destacou-se como feminista no sentido de sua constituição como uma escrita intencionalmente preocupada com as questões das mulheres e suas posturas em relação àquela sociedade. E, por estar inserida no sistema patriarcal e ditatorial que regia Portugal naquele momento, teve destino previsível: foi imediatamente retirada de circulação, e as autoras, condenadas a um processo judicial. Após a absolvição das "três marias", o livro teve uma boa recepção internacional, foi traduzido para outros idiomas

\footnotetext{
${ }^{7}$ MAGALHÃES, Isabel Allegro de. O sexo dos textos: traços da ficção narrativa de autoria feminina. Lisboa: Caminho, 1995, p. 23.
} 
e considerado ponto de destaque no pensamento e na criação literária das mulheres feministas.

No tecido do texto das Novas Cartas, encontra-se um tom de "denúncia da opressão e do domínio privado, vivida no corpo das mulheres, e a opressão no domínio público, palpável na sua inserção social e na sociedade em geral". ${ }^{8}$ As autoras expuseram desafiadoramente a fragilidade masculina, fizeram questionamentos sobre a sexualidade feminina e mostraram que o corpo das mulheres funciona como metáfora de formas de opressão escondidas e ainda não vencidas. Além desse teor inovador no que se refere à temática, Novas Cartas Portuguesas ainda manifesta um registro literário de grande qualidade.

Dois anos após a publicação das Novas Cartas Portuguesas, eclode em Portugal

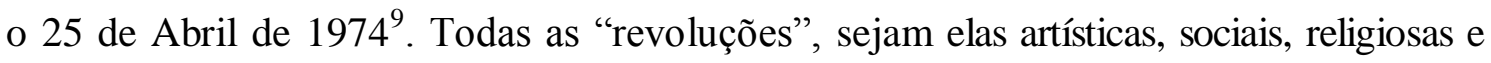
políticas, têm-se caracterizado, ao longo de toda a história humana, por deixarem atrás de si rastros transformadores de variada ordem, alcance e intensidade, e, não diferentemente, a Revolução dos Cravos (como também foi nomeado o 25 de abril de 1974) representa, depois da instalação da República, em 1910, o segundo acontecimento mais importante da História portuguesa do século XX e, talvez, um dos mais importantes de todo o processo histórico português, por causa dos desdobramentos e caminhos que suscitou e tem, ainda hoje, suscitado.

Foi um acontecimento histórico de longo alcance, pois transformou a vida dos portugueses, modificando as instituições sociais e, sobretudo, influenciando o âmbito artístico lusitano. A abordagem da produção literária portuguesa dos 30 anos que se seguiram ao 25 de Abril não pode deixar de sondar o modo como aquele movimento revolucionáro influenciou a atividade escritural dos autores lusitanos. Tal sondagem mostra-se instigante, no caso da

\footnotetext{
${ }^{8}$ MAGALHÃES, Isabel Allegro de. O sexo dos textos: traços da ficção narrativa de autoria feminina. Lisboa: Caminho, 1995, p. 22.

${ }^{9}$ Foi o movimento revolucionário que derrubou o regime salazarista português, em 1974, de forma a estabelecer as liberdades democráticas, promovendo transformações sociais em Portugal e simbolizando ilusões ou projetos de futuro para um país em ebulição. Esse regime foi preparado após o golpe militar de 1926, com o estabelecimento de uma ditadura no País. Posteriormente, em 1932, Antônio de Oliveira Salazar tornou-se primeiro-ministro das finanças e virtual ditador. Salazar instalou um regime inspirado no fascismo italiano e suprimiu, com a Constituição de 1933, as liberdades de reunião, de organização e de expressão. Em 1968, o ditador sofreu um derrame cerebral e foi substituído por seu ex-ministro Marcelo Caetano, que prosseguiu com sua política. A recusa em conceder independência às colônias africanas estimulou movimentos guerrilheiros de libertação em Moçambique, Guiné-Bissau e Angola. A decadência econômica e o desgaste com a guerra colonial provocaram descontentamento na população e nas forças armadas. Isso favoreceu a aparição de um movimento contra o regime ditatorial salazarista. No dia 25 de abril de 1974, explode a revolução, a dos Cravos, que põe fim aos 46 anos de ditadura. Com isso, "assistiu-se a um golpe de Estado sem grandes violências, mas que alterou radicalmente as estruturas políticas e econômicas." (SECCO, Lincoln, A Revolução dos Cravos e a crise do império colonial português. São Paulo: Alameda, 2004, p. 119).
} 
ficção portuguesa contemporânea, pois permite que seja demonstrada uma estreita vinculação das alterações sociais com a renovação do próprio percurso artístico dos escritores portugueses anteriores e subsequentes a 1974. Embora isso não reduza a literatura portuguesa contemporânea a uma mera consequência das mudanças políticas ocorridas sob a atmosfera libertária da Revolução, é inegável que a produção literária foi intensificada, tanto qualitativa quanto quantitativamente, com a eliminação dos mecanismos repressores que coibiam a produção artística lusitana. Consequentemente, o advento desse novo tempo criou, nos escritores, a necessidade de repensar os caminhos da expressão literária portuguesa.

O cenário literário que avulta a partir das últimas décadas do século XX caracteriza-se por narrativas revolucionárias não somente quanto à temática, mas sobretudo quanto à linguagem, especialmente no que se refere aos textos de autoria feminina. Será importante notar o surgimento, naquelas últimas décadas, de um número considerável de escritoras - e tantas delas de valor incontestável - e um vasto corpo de obras de ficção narrativa. A menção às autoras Maria Velho da Costa, Teolinda Gersão, Maria Gabriela Lhansol, Lídia Jorge, somente para citar algumas, sublinha a preocupação com a engenhosidade discursiva, remetendo a uma inovação formal operadora de diluições na conformação habitual dos gêneros literários. Para Magalhães, a escrita feminina tem uma identidade própria e

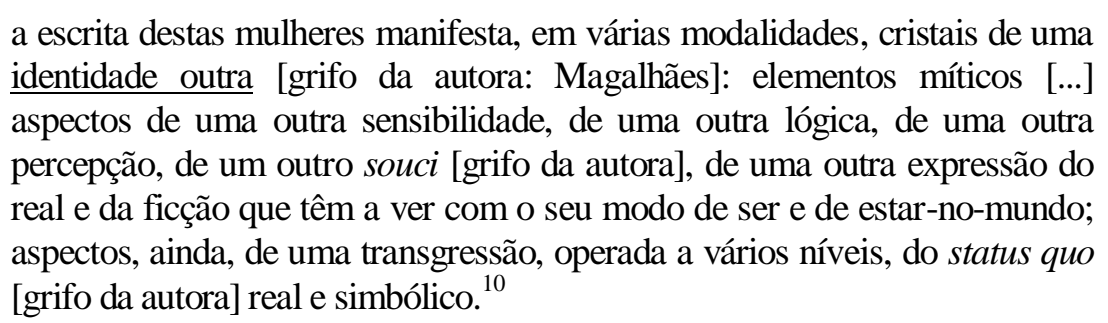

As vozes emergentes dessas produções revelam-se assumidamente femininas, traduzindo a revolta e a denúncia contra a globalidade de um sistema no qual as mulheres figuraram num plano assinalado pela submissão. Dentro desse panorama, a posição adotada por Lídia Jorge converge para a imagem da mulher mediterrânea. Numa entrevista concedida a Stephanie d'Orey, a autora declarou que, em seus romances, "A força da mulher é poderosa e subversiva, mas invisível socialmente." 11 Adepta dos que pretendem desvelar em seus romances temas que façam referência à sociedade, à vida para além do espaço restrito do lar e dos problemas privados, Jorge pretende privilegiar

\footnotetext{
${ }^{10}$ MAGALHÃES, Isabel Allegro de. O sexo dos textos: traços da ficção narrativa de autoria feminina. Lisboa: Caminho, 1995, p. 49.

${ }^{11}$ JORGE, Lídia. Interview with Lídia Jorge. Lídia Jorge: in other words. Massachusetts: 1999, p. 168. Entrevista concedida a Stephanie d'Orey. [tradução nossa]
} 
uma visão do mundo tal como é concebida pelas suas personagens femininas e acaba traçando um retrato inesquecível de numerosas mulheres.

Desde a publicação de $O$ dia dos prodígios, em 1980, poucos anos após a eclosão da Revolução dos Cravos em Portugal, é possível que grande parte da ficção de Lídia Jorge tenha sido elaborada com o intuito de ressaltar temas relacionados com a história, a memória e a identidade (quer pessoal, quer coletiva). Sua atividade literária, na qual se incluem outras narrativas objeto deste trabalho - o Cais das merendas (1982), Notícia da Cidade Silvestre (1984) e A Costa dos Murmúrios (1988), permitem situá-la como um marco inaugural de uma nova fase da narrativa na Literatura Portuguesa contemporânea.

Embora cada uma das narrativas mencionadas apresente características diferentes da anterior, parece que Lídia Jorge tem-se mantido ligada à ideia do empenhamento social do escritor, constituindo-se assim como autora de uma obra singular e de considerável importância para o momento atual da literatura portuguesa. De acordo com Santos, Lídia Jorge pode ser "considerada uma das inovadoras da narrativa portuguesa contemporânea, uma das mais representativas criadoras na ficção em língua portuguesa após o 25 de abril." 12

O seu primeiro romance mostra-se como um texto narrativo que pretende figuratizar a dinâmica de uma sociedade evocativa das realidades do Portugal rural. Como pano de fundo do lento decorrer da vida das personagens, das suas limitadas vivências, aliadas, porém, a fugas para o domínio da fantasia, Lídia Jorge coloca um acontecimento histórico de alcance significativo, a Revolução de Abril de 1974. Sendo assim, o romance foi publicado em 1980, porém o tempo da ação narrada é 1974. Seria legítimo afirmar que esse acontecimento, com seu alto grau de importância, afeta a composição do romance e, possivelmente, toda a produção literária posterior da autora. De fato, o tema da luta contra a opressão atravessa, de diversas formas, toda a obra da escritora. Neste romance especificamente, Lídia revisita sob uma perspectiva irônica, esse "dia maravilhoso": os soldados, ao final do romance, tentam, sem sucesso, anunciar de forma compreensível a notícia da revolução a camponeses semianalfabetos.

O exame do segundo livro, O cais das merendas, de 1982, permite identificar uma crise de identidade que, em última instância, sugere aquela vivida pelos portugueses após a Revolução dos Cravos, cindida entre o atraso a que os relegara a

\footnotetext{
${ }^{12}$ SANTOS, Rui Assis. Viagem pela cultura portuguesa - III. São Paulo: Seara Nova, 1993, p. 211-212.
} 
ditadura salazarista e o novo universo globalizado. A ação descreve um povo composto por imigrantes e estrangeiros, no limiar do esquecimento de si próprio, que procura sua identidade ao mesmo tempo em que a perde. A construção de um grande hotel (o Alguergue) e o desejo de melhorar a qualidade de vida colocam as personagens da Redonda (lugar de origem dos camponeses) na situação de terem de assimilar o modelo de sucesso representado pelo hotel. Na realidade, eles desejam construir uma ligação com o mundo no mesmo local onde se refugiam, traçando, assim, um possível retrato de um país à procura da sua identidade e não a adoção de modelos de comportamento e pensamento que não estabelecem relação com suas legítimas raízes.

No romance seguinte, Notícia da cidade silvestre, de 1984, o período que se segue ao 25 de Abril continua a ser objeto de análise, porém sob um ponto de vista diferente. Não só porque a ação, neste caso, se passa no ambiente urbano de Lisboa, mas ainda porque a narração se processa em primeira pessoa, destacando um ponto de vista feminino. O romance apresenta um ponto de vista feminino, porém - importa ressaltar - a comunidade que circunda a protagonista (Júlia Grei) não deixa de participar na constituição do seu processo identitário; mesmo porque, a identidade da cultura portuguesa também vai se constituindo em paralelo com a de Júlia. O dispositivo narrativo inaugurado com este romance parece manter-se em grande parte das obras posteriores.

Nele há uma voz feminina potencializada pelo tom confessional da narrativa e em busca da afirmação da sua própria individualidade. Júlia Grei, a personagem narradora, foi casada com um homem vinte e cinco anos mais velho e, desse casamento, deu à luz ao menino João Mário, apelidado de Joia. Júlia apresenta-se como uma figura desamparada e frágil, que, na verdade, não sabe como encontrar seu espaço no mundo, seu verdadeiro eu. Em função da sua insegurança, que se evidencia ainda mais com a morte do marido, a protagonista começa a seguir os passos de sua amiga, a datilógrafa Anabela, que exerce sobre Júlia uma espécie de poder e, desse modo, acaba se tornando um modelo para a protagonista.

A trajetória dessas duas personagens mostra a luta pela sobrevivência na Lisboa do final dos anos setenta. Após ter testemunhado passivamente as implacáveis estratégias usadas pela amiga no seu processo de ascensão social, Júlia tenta imitá-la, mas acaba por se dar conta de que esse modo de atuar põe em risco os seus entes mais queridos, por exemplo, o seu filho. 
Enquanto as duas obras anteriores apontavam para as falhas do novo regime em relação aos camponeses do Portugal rural, em Notícia da cidade silvestre parece que a autora pretende discutir a situação das mulheres em geral, especialmente as sozinhas com filhos para criar, como é o caso de Júlia. Focaliza também o ambiente e os valores artístico-culturais do final da década de 60 e início de setenta, incluindo os movimentos populares de Maio de 68, a primeira viagem do homem à Lua e o desencanto que se sucede a esse período.

Este romance trata dos problemas de uma mulher confrontada com transformações e mudanças numa época histórica turbulenta, e o mesmo se pode dizer d'A costa dos murmúrios, de 1988. A temática feminina continua, mas acrescida de uma outra questão. Os acontecimentos evocados neste romance se passam em Moçambique durante a Guerra Colonial, que levaria, eventualmente, ao colapso do Estado Novo, em Abril de 1974. A obra divide-se em duas partes: o conto Os gafanhotos (narrado em terceira pessoa, que não só coloca em segundo plano a guerra em cujo contexto decorre o feliz acontecimento - a festa de casamento de Evita e Luís Alex, os protagonistas do romance - como também apresenta uma perspectiva aparentemente otimista, mesmo quando faz referência a mortes sucessivas); a segunda parte, em que aparece a protagonista já em sua fase adulta: Evita passa a protagonizar com o nome de Eva Lopo. A todo o tempo a narradora faz referências à primeira parte, numa superposição de planos - presente e passado - e de espaços - o da Guerra Colonial e o do pós-guerra. A narradora recorda, nessa segunda fase, uma visão bem mais crítica da realidade, o que põe em evidência o vazio e a falta de objetivos no cotidiano das mulheres dos oficiais durante as longas ausências dos maridos.

Evita/Eva Lopo era diferente e tinha, em relação às outras mulheres que se apresentam na narrativa, uma visão mais ampla da realidade, a ponto de querer desvendar o crime cometido contra os negros encontrados mortos na praia.

As demais obras da autora, ainda que não integrem o corpus deste trabalho, indicam trilhas que apontam para questões relativas não somente à sondagem do universo feminino, mas também à psicologia masculina (como ocorre no romance posterior a Notícia da cidade silvestre, intitulado A última dona (1992). Na sequência apresentam-se os seguintes textos: A instrumentalina e $O$ conto do nadador (1992 contos), O jardim sem limites (1995 - romance), Marido e outros contos (1997 antologia de contos), A maçon (1997 - peça teatral), O vale da paixão (1998 romance), O vento assobiando nas gruas (2002 - romance), A manta do soldado (2003 
- romance), O belo adormecido (2004 - antologia de contos), Combateremos a sombra (2007 - romance), O grande vôo do pardal (2007 - literatura infantil), Praça de Londres (2008 - antologia de contos), Contrato sentimental (2009 - ensaio), Romance do grande gatão (2010 - literatura infantil), A noite das mulheres cantoras (2011) e seu mais recente romance, Os memoráveis (2014).

Dentre os múltiplos ângulos observados pela crítica, os que apontam para a singularidade de Lídia Jorge estão ligados à variedade do topos espacial característico dos romances da autora. A dimensão espacial, enquadrada histórica, física e culturalmente, afeta as personagens, seus destinos e altera-lhes também o cotidiano. À preocupação com a diversidade dos ambientes somam-se outras características, dentre as quais se destacam as reflexões acerca da escrita, o tema da mulher oprimida e os questionamentos relativos à identidade. Nas narrativas apresentadas como corpus $(O$ dia dos prodígios (1980), O cais da merendas (1982), Notícia da cidade silvestre (1984) e A costa dos murmúrios (1988) o percurso de vida (externo e psicológico) das protagonistas possibilita o delineamento da trajetória percorrida para o conhecimento de si mesmas rumo à construção da identidade da mulher portuguesa, tema que constituirá a prioridade deste estudo. Ressalte-se, contudo, que não será possível desvincular essas figuras femininas (Carminha e Branca Volante; Rosária, Júlia Grei e Evita/Eva Lopo) das demais personagens, especialmente as masculinas, pois é por meio do contato e confronto entre elas que se dá, não apenas o processo de tomada de consciência, mas também o da construção da identidade ${ }^{13}$.

A identidade, na concepção pautada em Stuart Hall ${ }^{14}$, encontra-se na mira da teoria social. A identidade do homem na sociedade moderna era bem definida e localizada no mundo social e cultural. Mas, no espaço contemporâneo, as constituições identitárias sofrem mudanças estruturais que, no final do século $\mathrm{XX}$, transformam as sociedades modernas. Essas transformações fragmentam as paisagens culturais de classe, gênero, sexualidade, etnia, raça e nacionalidade, que, no passado, forneciam aos indivíduos sólidas localizações como seres sociais. Isso também acaba desestabilizando "nossas identidades pessoais", abalando a ideia que temos de nós próprios como sujeitos

\footnotetext{
${ }^{13}$ A identidade foi mencionada como característica da narrativa produzida nos anos que precedem imediatamente o 25 abril de 1974 pelos críticos Álvaro Cardoso Gomes, Antônio José Saraiva, Eduardo Lourenço, Massaud Moisés, entre outros, muito embora nenhum deles se tenha detido no tratamento dessa questão, na análise e interpretação do processo de construção da identidade feminina colhido no interior da escrita de Lídia Jorge, como é o nosso interesse.

${ }^{14}$ HALL, Stuart. A identidade cultural na pós-modernidade. Trad. Tomaz Tadeu da Silva. 11. ed. Rio de Janeiro: DP\&A, 2006.
} 
integrados. Esta perda de um "sentido de si" estável é chamada, algumas vezes, de deslocamento ou descentração do sujeito. "15

Para os propósitos da exposição que se refere a identidade, Hall distingue três concepções bem diferentes: a do sujeito do Iluminismo, a do sujeito sociológico e a do sujeito pós-moderno. A primeira traz em sua essência a noção de um indivíduo totalmente centrado, dotado das capacidades de razão. A segunda, noção de sujeito sociológico, anuncia as transformações sofridas pelo sujeito a partir do seu contato com a complexidade do mundo moderno. Na terceira concepção apresenta-se o sujeito pósmoderno como um indivíduo não dotado de uma identidade fixa, essencial ou permanente. Nesse terceiro momento a identidade torna-se uma "celebração móvel" 16

De acordo com Hall (2006), um dos grandes marcos da modernidade tardia, que podem trazer alguma luz à compreensão do tema enfocado neste trabalho, remete ao impacto dos movimentos sociais que emergiram na década de sessenta, o feminismo fazendo parte desse grupo. Esse movimento teve uma relação mais direta com o descentramento do sujeito cartesiano e sociológico, na medida em que questiona a distinção entre o "dentro" e o "fora"; o "público" e o "privado". Além disso, o feminismo politizou a subjetividade, a identidade e o processo de identificação, promovendo discussões acerca de questões como a família, o trabalho doméstico, a sexualidade, o cuidado com as crianças etc. Sendo assim, aquilo que começou como um movimento dirigido à contestação da posição social das mulheres contribuiu para a formação das identidades sexual e de gênero.

Interessa, aqui, identificar e apontar os mecanismos que colaboram para a expressão de um tipo específico de identidade de gênero - o feminino - no contexto da produção romanesca de Lídia Jorge, especificamente nos quatro primeiros romances da autora, examinando como se desenvolve o processo de formação da consciência rumo à construção da identidade feminina. A identidade como processo, observada em numerosos momentos, enforma a ficção de Lídia Jorge e parece estar presente como indicadora interna da leitura que o próprio texto se propõe. Além disso, pode-se encontrar a identidade atravessando todos os níveis da construção ficcional presentes nos elementos estruturais da narrativa (de personagens a foco narrativo, até na própria linguagem). Assim, é nossa intenção examinar como se constrói e articula, tanto em

\footnotetext{
${ }^{15}$ HALL, Stuart. A identidade cultural na pós-modernidade. Trad. Tomaz Tadeu da Silva. 11. ed. Rio de Janeiro: DP\&A, 2006, p. 9.

${ }^{16}$ Ibidem, p. 13.
} 
cada uma quanto no conjunto das quatro obras que compõem o corpus deste trabalho, na proposta significativa das obras, quer tomadas individualmente, quer como um todo, o processo de conscientização e construção da identidade feminina.

Será igualmente importante examinar o contexto histórico-cultural, tanto o textual quanto o extratextual, razão pela qual serão enfocadas também as categorias de tempo e espaço, através das quais emergirão os sistemas de valores e a "visão de mundo" específicos do universo rural, de cariz arcaico, de $O$ dia dos prodígios e $O$ cais das merendas, e os urbanos, que emergem pelos olhos de personagens que, talvez, se pretendam dotadas de alguma consciência histórica, como se vê em Notícia da cidade silvestre e A costa dos murmúrios.

Quanto à categoria do tempo, em termos de elemento romanesco, Massaud Moisés ${ }^{17}$ o distingue em duas concepções: cronológico, ou histórico, e psicológico, ou metafísico. O primeiro denomina-se “empiricamente perceptível” e corresponde à marcação das horas no relógio. Apresenta-se linearmente, como se os acontecimentos transcorressem numa linha reta, seguindo um "antes" e um "depois" rigorosamente materializados. Inversamente, o tempo psicológico, ou metafísico, porque interior, se desenvolve infenso a qualquer ordem, exceto a emprestada pelos próprios fluxos emocionais que lhe estão por natureza vinculados; além do mais, flui dentro das personagens como um tempo-duração, sem começo, nem meio, nem fim. Pode ser considerado, ainda sob o ponto de vista de Moisés (1995), como tempo relativo, sendo, por isso, também chamado de "tempo ontológico". Vale ressaltar, ainda, que o tempo metafísico pode manifestar-se a partir do fluxo de consciência das personagens, do monólogo interior, da memória etc, recursos bastante presentes nas quatro obras sob análise.

O exame desse tempo metafísico possibilitará a compreensão do processo de conscientização das personagens femininas, pois ele está presente orientando a visualização da embrionária identidade feminina nas obras sob análise. Mas é importante ressaltar que é do confronto entre o tempo histórico (da ditadura, da pósditadura e da Guerra Colonial em Moçambique) e os demais aspectos do tempo, inclusive o psicológico, que se poderá examinar o processo de construção da identidade feminina dentro desses contextos.

\footnotetext{
${ }^{17}$ MOISES, Massaud. A criação Literária: prosa. 15. ed. São Paulo: Cultrix, 1995, p. 185.
} 
A referência ao espaço, outra categoria também de significativa importância para o texto ficcional, pode remeter, de acordo com Moisés ${ }^{18}$, ao campo ou à cidade, mas depende de seu caráter linear ou vertical a maior ou menor importância assumida pelo cenário. $\mathrm{O}$ espaço referido em $O$ dia dos prodígios e $O$ cais das merendas remete ao campo: o primeiro apresenta uma sociedade rural e arcaica que vive num vilarejo chamado Vila Maninhos, o segundo trata de uma comunidade eminentemente agrária e a ação do romance desenrola-se à beira-mar, numa praia do Sul de Portugal. Nos outros dois romances, Notícia da cidade silvestre e A costa dos murmúrios, há referência ao espaço citadino, a saber, respectivamente, uma narrativa se desenvolve no grande centro urbano de Portugal, Lisboa, exatamente após o Abril de 1974 e a outra se desenrola no espaço da guerra colonial em Moçambique, e também no contexto urbano português após a Revolução dos Cravos.

Esses espaços, na paisagem dos romances, parecem ter a função de desencadear, no íntimo das personagens, especialmente das femininas, uma viagem ao interior do "eu", porque o comportamento das personagens, tanto das que vivem no campo quanto daquelas que habitam os centros urbanos, reflete o ambiente em que se situam. Daí a pretensão de examinar a possibilidade de esses espaços influenciarem o processo de formação da consciência e da construção da identidade feminina.

Nesta pesquisa, a escolha dessa temática se deveu primeiramente ao modo como, em suas obras, a autora constrói suas personagens femininas em evidente tensão, não apenas com seu contexto imediato, mas também com o passado que as moldou de forma tão conflituosa. Nelas, chama a atenção não seu retrato físico, mas o estado processual de sua consciência, em estado de evolução. Assim, interessa examinar o contexto histórico-social da segunda metade do século $\mathrm{XX}$, que germinou o espírito revolucionário propulsionador da Revolução dos Cravos, que pôs fim à ditadura de Salazar e de outras grandes revoluções e guerras posteriores à disseminação dos movimentos socialistas da década de 60, e que ajudou a criar a mulher com uma nova consciência de si e grande potencialidade de seus papéis sociais. Mas interessa também examinar a contribuição oferecida pelo passado mítico e por certas figuras femininas míticas, como Eva, Penélope e Helena de Troia, para a construção da consciência das personagens femininas focalizadas neste estudo. Vale afirmar ainda a importância do

\footnotetext{
${ }^{18}$ MOISÉS, Massaud. A análise literária. 15. ed. São Paulo: Cultrix, 2005, p. 107.
} 
estudo acerca da ironia e da paródia, pois as figuras míticas relacionadas acima vêm à luz na leitura por meio de reverberações paródicas e irônicas.

A maneira irônica de construir as personagens e de, assim, questionar os conflitos sociais postos em cena chama atenção nas obras de Lídia Jorge. Isso pode ser mostrado por meio das ações de algumas personagens e pelo efeito parodístico que se forma em torno dessas ações. A paródia aponta para duas posições principais: por um lado, para a riqueza simbólica de que se reveste um discurso, por outro, para conduzir a decodificações que levam ao que se pode chamar de "avesso do texto". Pelo que se nota, trata-se, no que se refere à paródia, de uma nova possibilidade de interpretação do convencional com uma tomada de consciência crítica. Considera-se a paródia, então, um ato crítico de reavaliação e acomodação, pois recusa e esvazia um modelo original para recriar e preencher um modelo preexistente.

Pode, ainda, a paródia, apresentar-se como canto paralelo, como diálogo intertextual ou como simples retomada de um texto preexistente. Considerada como a linguagem da inversão, a paródia inscreve o "mesmo", mas obliquamente, ao revés, revirado, e o reconduz ao novo texto como crítico. Como linguagem de ruptura, este recurso procura um corte com o convencional realizando uma inversão e um deslocamento. Em outras palavras, a paródia apresenta-se como uma escrita autocrítica, a voz social ou individual reprimida, que é preciso desentranhar para que se conheça o outro lado da "verdade".

Para Hutcheon ${ }^{19}$ a ideia que se tem a respeito do conceito de paródia se amplia e se completa como "uma sobreposição de textos que incorporam o antigo no novo" 20 . Sua retomada inclui a insistência de que se trata de um recurso metafórico, já que um segundo sentido é construído, mas que mantêm uma distância fundamentalmente crítica e irônica entre os dois textos. Hutcheon também considera a interdição negativa que a paródia carrega por ser incluído, dentro de sua definição, o "ridículo", mas, ainda assim, acentua que "a paródia, em especial na forma reverente, torna-se[...] uma forma de preservar a continuidade na descontinuidade". ${ }^{21}$ Além disso, reforça a possibilidade de considerar a fundamental importância da ironia para a existência do sentido paródico, uma vez que, do ponto de vista da autora, a ironia implica a paródia e vice-versa. Com

\footnotetext{
${ }^{19}$ HUTCHEON, Linda. Uma teoria da paródia. Trad. Teresa Louro Pérez. Rio de Janeiro: Edições 70, 1985.

${ }^{20}$ Ibidem, p. 50.

${ }^{21}$ Ibidem, p. 123.
} 
base no exame mais detalhado desses recursos, paródia e ironia, se torna possível pensar com cautela a construção da identidade feminina nos romances sem correr o risco de ficarem as figuras femininas mal compreendidas.

Pelas evidências, como já mencionado, este enfoque da figura feminina não poderá prescindir do estudo de seu contraponto masculino. Sendo assim, é possível verificar que a consciência se forma no contato com o outro e, segundo Foucault, num contato que envolve, na maioria das vezes, o poder. Assim, torna-se justificável observar os mecanismos pelos quais o regime salazarista (discurso masculino, dotado de poder) pode ser considerado como um elemento dificultador (no sentido de colaborar para o estabelecimento de uma relação de dependência e subalternidade da mulher perante o homem) para o desenvolvimento da construção da identidade feminina.

O campo de atuação da mulher nesse contexto social vigente durante o período acirrado da ditadura portuguesa governado por Oliveira Salazar, se mostra limitado, restringindo-se ao lar e à família. Consequentemente, ao que tudo indica, neste espaço serão educadas as mães para prepararem seus filhos. Neste sentido, e para reforçar esta ideologia, tomam-se em conta os condicionantes biológicos típicos de uma mulher, a reprodução da espécie, justificando, assim, todo o sistema legislativo e o enquadramento social dado a ela. Atribui-se, então, à mulher, no contexto da ditadura salazarista, os papéis sociais de mãe, esposa, educadora dos filhos e religiosa.

Esses papéis sociais atribuídos à mulher pela sociedade podem contribuir para o não desenvolvimento da consciência de si mesma. Porém, de acordo com Clark e Holquist ${ }^{22}$, o ser humano se pretende respondível por suas atitudes e essas estão em constante mutação. Desse modo, "Eu calibro o tempo e o lugar de minha própria posição, que está sempre mudando, pela existência de outros seres humanos e o meio natural por meio dos valores que articulo em atos." ${ }^{\mathbf{2 3}}$.

Para Bakhtin (1998) o outro se torna fundamento de toda existência, pois a constituição de um ser não se dá sem a relação com o outro. A isso Bakhtin dá o nome de "outridade", e o diálogo se mostra como a estrutura que favorece a existência particular por propiciar uma constante troca entre o que já é e o que não é ainda. A relação que se desenvolve entre "eu" e "outro", de acordo com o teórico, forma a

\footnotetext{
${ }^{22}$ CLARK, Katerine; HOLQUIST, Michael. Mikhail Bakhtin. Trad. J. Guinsburg. São Paulo: Perspectiva, 1998.

${ }^{23}$ Ibidem, p. 90.
} 
consciência humana e essa consciência estabelece um intercâmbio contínuo entre as atividades do "eu" e tudo o que é "não-eu-para-mim".

$\mathrm{Na}$ realidade, a consciência não se forma porque há, nas relações, um movimento de constante transformação que não permite que haja uma consciência pronta, acabada, estática. Portanto, seria pouco provável considerar uma ideia de permanência porque, na medida em que há esse contato com o outro, uma nova consciência se forma para, em seguida, se transformar, dando a ideia de um ciclo que não tem fim, e que pode remeter a um processo pelo qual se passa a construção da identidade.

Assim, segundo Bakhtin, a identidade pode ser explicitada como uma síntese dialética, o sujeito enquanto indivíduo (Eu) na relação com o outro. Desta maneira, a identidade para outrem, ou atribuída, se constitui num processo relacional consigo mesmo no curso do tempo ou com o outro no plano grupal. A articulação do "se reconhecer" e "não se reconhecer" ocorre por intermédio da atividade e da consciência, ou seja, as identidades, nos seus traços comuns, refletem a estrutura social, ao mesmo tempo em que reagem sobre ela, conservando-a ou transformado-a, dando a ideia de tensão entre a permanência e as mudanças na definição da identidade. Sendo assim, a identidade pode ser entendida como algo que não pode ser adquirida de forma definitiva e exterior, pois se constitui num processo de construção, desconstrução e reconstrução constantes.

No caso das obras de Lídia |Jorge, ao trazer à luz determinadas figuras femininas dos romances $O$ dia dos prodígios (1980), O cais das merendas (1982), Notícia da cidade silvestre (1984) e A costa dos murmúrios (1988) objetiva-se examinar quais estratégias discursivas auxiliam no desenvolvimento do processo de construção da identidade dessas personagens femininas (entendendo que tal processo pode estar relacionado à condição feminina nos contextos socioculturais e históricos portugueses no período que antecede e sucede a Revolução de Abril de 74). Evidentemente, a par dessas estratégias, pretende-se verificar quais efeitos de sentido tais estratégias permitem alcançar. Para além do ambiente em que as personagens femininas estão inseridas, pretende-se promover uma reflexão acerca das relações entre elas e o contexto espaço-temporal, podendo, assim, propor uma investigação da relação entre o presente da ação narrada e o passado mítico.

A escolha, nessa pesquisa, recaiu sobre as quatro obras mencionadas, porque, ao que parece, o tema do processo de construção da identidade feminina perpassa a maioria 
dos textos de Lídia Jorge. Especificamente, nos quatro primeiros romances (objetos de estudo neste trabalho), sua recorrência se evidencia, possibilitando um exame simultâneo desse processo de construção da identidade da mulher e da cultura portuguesas.

Pelo que se percebe nas obras que compõem o corpus, há atividades praticadas por certas personagens que as distinguem das demais do grupo ou que permitem confrontá-las com outras que diferem delas. N'O dia dos prodígios, este estudo recorta o "bordar" de Branca Volante, o "limpar as vidraças", de Carminha Parda e o compor quadras de Macário, tão acima das ações corriqueiras dos demais habitantes da comunidade. De fato, num estudo mais aprofundado, poder-se-á ver que estas personagens se distinguirão por um tipo diferente de prodígios, benéficos para a constituição da identidade, e resultantes, em grande medida, das atividades que praticam.

Também em grande medida pode-se conjeturar que os movimentos internos das personagens, em $O$ dia dos prodígios, ao bordarem, limparem e comporem quadras podem proporcionar a essas personagens um mergulho no seu interior. No segundo livro, O cais das Merendas, é possível perceber que há uma inserção, por meio da escrita, no interior da personagem Rosária. Além disso, por meio da memória coletiva, é provável que se tenha uma ausência toda feita de presença, quando as personagens querem esquecer o passado sofrido das merendas e, ao mesmo tempo, não conseguem se desvencilhar da lembrança de Rosária (personagem que representa a identidade daquele povo).

Se, no primeiro romance, as ações da comunidade se pautam na presença ameaçadora da cobra (que é preciso matar), nesta é Rosária a presença/ausência que é preciso esquecer. Neste segundo texto, será esta personagem uma alegoria? De quê? Que leitura se poderá fazer dela? Em que medida ela impede ou auxilia a comunidade a encontrar (ou reencontrar?) sua identidade?

Nos dois romances seguintes (Notícia da cidade silvestre e A costa dos murmúrios), a atividade recortada é o escrever. No caso de Júlia, personagem do terceiro texto, trata-se de indagar e examinar o papel e a contribuição oferecidos pela escrita entre o epistolar e o memorialístico, do tipo diário, no processo de autoconhecimento da protagonista. Neste mesmo romance também desperta nosso interesse a contribuição oferecida pela Literatura e o sentido desta Revolução para a construção da identidade das personagens (não apenas de Júlia). Enfim, na quarto 
romance, A costa dos murmúrios, o foco recai sobre a personagem Evita e, posteriormente, sobre Eva Lopo, então uma historiadora. A indagação de agora remete à contribuição da História no processo de constituição das personagens femininas e, simultaneamente, do contexto sociocultural do qual participam.

Enfim, a nosso ver, há uma evolução tanto no processo de autoconsciência das personagens quanto no contexto em que se inserem, que implica um trânsito do mito para a História, e que envolve, inclusive, a estrutura das narrativas enfocadas, que acompanha tal evolução.

As narrativas de Lídia Jorge se direcionam para uma tendência à análise do comportamento das personagens no que se refere às posturas contrastantes adotadas por algumas em relação àquelas esperadas da mulher portuguesa tradicional (educada no seio da família católica e situada num contexto patriarcal e falocêntrico, em que, durante séculos, seu papel ficou restrito ao de mãe e esposa absolutamente resignada ao marido, entendido, inclusive do ponto de vista legal, como "chefe de família"). As posturas referidas sinalizam as mudanças reivindicadas por feministas desde as primeiras décadas do século XX, embora contrastem com a condição social e política da mulher portuguesa dos anos do regime.

A posição adotada por Virgínia Ferreira ${ }^{24}$ que enfatiza a condição social das mulheres em numerosos domínios (como por exemplo, ser-lhes aberto o acesso a todas as carreiras profissionais) mostra que, durante o período de consolidação e instauração da democracia portuguesa, entre 1974 e 1979, altera-se a condição social feminina. A saber, nesse período alarga-se o direito ao voto; retiram-se aos maridos os direitos de lhes violar a correspondência e não autorizar a saída da mulher do país; estende-se a licença-maternidade para noventa dias; reconhece-se constitucionalmente a igualdade entre homens e mulheres em todas as áreas. Com isso, de acordo com as conquistas alcançadas no âmbito do universo feminino, foi possível visualizar que as amarras envolvendo a livre expressão da feminilidade na sociedade portuguesa abrangem fatores de ordem moral, política, econômica, social e religiosa e que esses fatores contribuíram, uns muito significativamente outros nem tanto, para um avanço paulatino das conquistas relativas aos direitos da mulher.

Os acontecimentos importantes que acometeram a sociedade portuguesa do século XX e contribuíram para a construção de um novo olhar em relação aos direitos

24 FERREIRA, Virgínia. As mulheres em Portugal: situações e paradoxos. Disponível em: http://www.ces.uc.pt/publicacoes/oficina/ficheiros/119.pdf. Acessado em: 09/07/2012. 
da mulher - Revolução de 74 e Movimentos feministas - se mostram como força propulsora para o início de uma discussão acerca dos direitos das mulheres, mas não apresentam uma solução definitiva, pois ainda há muitas questões que precisam ser pensadas. Em outras palavras, mesmo com o advento do Abril de 74, que colocou fim à ditadura e proporcionou à figura feminina certa liberdade se comparada à coação que sofria em função da repressão forjada pela estrutura dominante, e com a emergência dos movimentos feministas que contribuíram com muitas transformações para o universo feminino, as mulheres ainda se pretendem inseguras e propícias à submissão.

Pode ser que a incidência desses fatos (tendência à submissão e à servidão) recaia nos papéis que a sociedade ainda impõe às mulheres, considerados como exclusivamente femininos (aqueles que se relacionam aos afazeres domésticos, por exemplo); ou por estarem vinculadas à estrutura patriarcal que evidencia a relação de subalternidade entre homem e mulher; ou, ainda, o que parece mais conveniente, iniciase, com esses acontecimentos, um projeto de transformação da consciência feminina, ou seja, há indícios de que a mulher comece a formar consciência de si mesma e isso não se processará instantânea e isoladamente, mas se constituirá gradualmente e na relação com o outro.

Esse movimento torna-se cíclico na medida em que a consciência de si se desenvolve para se transformar e se recriar novamente. Para isso, uma incursão na teoria acerca da consciência e da identidade, especificamente a de gênero, o feminino, pode favorecer o encaminhamento de muitas interpretações ao longo da análise das personagens, em especial das femininas, para que se possa examinar a possibilidade de investigação da noção de identidade feminina pelo viés sociológico. 
CAPÍTULO I

O DIA DOS PRODÍGIOS: IDENTIDADE (FEMININA) GERMINAL 
Pensar os processos identitários envolve não apenas a identificação de um indivíduo pelos outros (a atribuição externa de uma identidade), mas também os processos através dos quais esse mesmo indivíduo constrói uma concepção singular e distintiva de si próprio. Com isso, acredita-se no surgimento da possibilidade de criação de um "self" nos diferentes contextos.

Assim, refletir sobre a identidade feminina pressupõe usar como ponto de partida essa concepção de reconhecimento de um "self"; no entanto, pode-se considerar ainda que "a identidade da mulher constrói-se na relação familiar com os outros - o marido e os filhos - e, nesse território privado que é a casa, ela "governa a vida". Ser esposa e depois tornar-se mãe é percorrer e completar as etapas de uma carreira familiar já prevista." ${ }^{25}$ Nessa carreira, ao lado de um marido ou de outra figura masculina, se a mulher não estiver em matrimônio (situação em que está implícito um "arrumar-se" na vida), ela provavelmente estará submetida a uma autoridade que pode aparecer concentrada na figura masculina. Isso sugere uma relação de subalternidade, proibição, repressão e castigo da mulher em relação ao homem e, diante das circunstâncias, a mulher acaba aceitando passivamente essa situação.

Dentro desse espaço doméstico, mesmo que inconscientemente (e a despeito dessa repressão em razão da imposição masculina), a mulher constroi certo poder. De acordo com Almeida:
A mulher adquire, pela prática, uma autoridade permanente, regular e contínua sobre o funcionamento da unidade doméstica e os comportamentos familiares; através de conselhos, sugestões e uma vigilância discreta, orienta e estimula modelos de conduta dos filhos - atuando menos pela repressão direta (como o marido) do que pela sugestão; é de certa maneira um poder que não se sente, porque constantemente atua na discrição dos meandros de uma tomada de decisão. É sobretudo um poder de que não se fala, silenciado e invisível no discurso comum. ${ }^{26}$

O trecho descrito nos mostra que há uma disparidade entre os dois níveis de realidade. Enquanto a mulher representa a figura passiva perante o homem, ou seja, obedece às ordens impostas pelo masculino, ela também exerce a função de administradora das práticas domésticas (tudo que se refere a manter a ordem do lar e daqueles que o habitam) e essas práticas "a colocam numa posição-chave de

\footnotetext{
${ }^{25}$ ALMEIDA, Ana Margarida Nunes de. Entre o dizer e o fazer: a construção da identidade feminina. Análise Social, v. XXII (92-93), 1986, $3^{\circ}$ e 4ํ, p. 493-520, p. 499.

${ }^{26}$ Ibidem, p. 503.
} 
funcionamento da unidade doméstica - não só material, como também afetiva"27. Na medida em que a afetividade começa a aflorar, acredita-se que a mulher possa iniciar um processo de reconhecimento interno, de busca de uma identidade feminina, para que, consequentemente, possa encontrar o seu lugar no mundo.

Tendo em mente esses pressupostos, descobrir e explorar as representações com que as mulheres constroem a sua identidade, ou seja, pensar a identidade feminina levando em consideração a maneira pela qual a mulher fala de si própria, é a principal intenção desta investigação. E o corpus que auxiliará nesta tarefa é constituído pelas quatro primeiras obras de Lídia Jorge.

O primeiro romance, O dia dos prodígios (1980), suscita uma série de questões de interesse no sentido de, por meio da análise das personagens, não somente das femininas, mas também, e não menos importantes, das masculinas, investigar como ocorre o processo de construção da identidade feminina. Acredita-se que, já a partir do título do romance, a autora pode sugerir como transcorre a vida no vilarejo fictício de Vilamaninhos onde a ação se passa e como se desenvolvem as relações naquele lugar.

Em primeira instância, convém reportar-se ao sentido denotativo do vocábulo "prodígio", presente no título da obra. De acordo com Houaiss, a palavra possui quatro definições: "1. Acontecimento que é ou parece estar em contradição com as leis da natureza; 2. Coisa ou fato extraordinário; maravilha, milagre; 3. Pessoa que apresenta alguma habilidade ou talento; 4. Que ou o que possui excepcional inteligência ou talento para a sua idade." 28

Ao observar o ambiente de Vilamaninhos, é pouco provável que a definição de número quatro se enquadre entre as características dos aldeões, já que não se trata de uma comunidade de pessoas com algum grau de esperteza, safas. Já a acepção de número dois parece se adequar mais às características do povo da aldeia, que, em dois momentos, se depara com fatos que, do ponto de vista deles, são extraordinários: o primeiro quando ocorre o episódio da cobra, que no imaginário daquele povo, se transforma em dragão, alça voo e desaparece misteriosamente; o segundo, quando surgem no vilarejo soldados fardados num carro de guerra, sem darem nenhuma explicação plausível, do ponto de vista dos aldeões, sobre quem eles, esses soldados, eram e de onde vinham.

\footnotetext{
${ }^{27}$ ALMEIDA, Ana Margarida Nunes de. Entre o dizer e o fazer: a construção da identidade feminina. Análise Social, v. XXII (92-93), 1986, 3ํ e 4º p. 493-520, p. 504.

${ }^{28}$ HOUAISS, Antônio. Dicionário da Língua Portuguesa. Rio de Janeiro: Objetiva, 2001, p. 2304.
} 
A palavra "prodígio" tem ainda um significado bíblico e, nesse viés, significa a ocorrência de experiências sobrenaturais que nos fazem maravilhar com o tremendo poder de Deus. De fato, em alguns capítulos do "Livro de Salmos", a palavra "prodígio" é traduzida por "maravilhas". Maravilhas geram temor a Deus. Nesse caso, temor não tem conotação de medo, mas de respeito, reverência.

O episódio da cobra que aparece no vilarejo e desaparece sem deixar rastros pode ser um exemplo de acontecimento extraordinário. Aparentemente, trata-se de uma simples cobra, mas, quando os aldeões mencionam o desaparecimento dela, criam em torno desse fato uma atmosfera sobrenatural, capaz de transformar a serpente numa espécie de mito. Eles ainda criam uma expectativa de que, em algum determinado momento, alguém virá para explicar o desaparecimento dessa estranha cobra alada, e esse sentimento vai sendo cada vez mais alimentado ao longo da narrativa.

O termo "mito" pode ser utilizado, de acordo com estudiosos, de forma pejorativa para se referir às crenças comuns (consideradas sem fundamento objetivo ou científico, e vistas apenas como histórias de um universo puramente maravilhoso) de diversas comunidades, porém no imaginário dos vilamaninhenses, esse episódio parece ter proporções reais. De acordo com Eliade, "o mito é considerado uma história sagrada e, portanto, uma 'história verdadeira', porque sempre se refere a realidades" ${ }^{29}$. No caso de Vilamaninhos a história da cobra voadora incorpora-se à realidade daquele povo, de tal modo que as personagens do vilarejo parecem viver o mito no sentido de algo que é impregnado pelo poder sagrado.

Viver o mito, para Mircea Eliade, constitui "uma experiência verdadeiramente "religiosa" ${ }^{30}$, pois ela se distingue da experiência ordinária da vida quotidiana", assim como a realidade em que vivem os aldeões parece não condizer com o mundo cotidiano real. Ainda sob o ponto de vista de Eliade,

a "religiosidade" dessa experiência deve-se ao fato de que, ao reatualizar os eventos fabulosos, exaltantes, significativos, assiste-se novamente às obras criadoras dos Entes Sobrenaturais; deixa-se de existir no mundo de todos os dias e penetra-se num mundo transfigurado, autoral, impregnado da presença dos Entes Sobrenaturais. [...] Isso implica igualmente que ele deixa de viver no tempo cronológico, passando a viver no Tempo primordial, no Tempo em que o evento teve lugar pela primeira vez. É por isso que se pode falar no "tempo forte" do mito: é o Tempo prodigioso, "sagrado", em

${ }^{29}$ ELIADE, Mircea. Mito e Realidade. 6. ed. São Paulo: Martins Fontes, 2004, p. 12
${ }^{30}$ Ibidem, p. 12. 
que algo de novo, de forte $e$ de significativo se manifestou plenamente. $^{31}$

A aparição da cobra como ente sobrenatural se mostra bastante oportuna para os aldeões mergulharem neste "mundo transfigurado" e ainda proporciona uma vivência nesse "Tempo prodigioso", marcado pela circularidade, no sentido de não apresentar projeção de passado e futuro, e pela estaticidade, de maneira que revivem aquele mesmo evento, no mesmo tempo. Por outras palavras, o povo do vilarejo revive o episódio da cobra (algo que para eles se tornou forte e significativo) como se fosse a primeira vez, como se fosse um fato possível de acontecer somente naquele espaço, com aquelas pessoas, num tempo que parece existir somente no imaginário dos aldeões. E esse acontecimento parece não dar vazão a que ocorram outros fatos e, consequentemente, a que não haja uma continuidade. Como se os camponeses estivessem inseridos num tempo estático, numa espécie de vivência interna, no tempo interior.

Além disso, Vilamaninhos parece se situar num mundo arcaico e, de acordo com Eliade $^{32}$, "para o mundo arcaico, o mito é real porque ele relata as manifestações da verdadeira realidade: o sagrado." A cobra parece ter-se transformado, para os aldeões, em algo sagrado, pois, pelo que mostra a narrativa, eles atribuem a esse réptil características que não são verossímeis (ela tem asas cintilantes, escamas brilhantes e é capaz de alçar voo) e, por isso, referem-se a ele com certo respeito, como se fosse algo divino ou até mesmo sagrado. Além disso, parece que há, inserido naquele vilarejo, certo grau de primitivismo, que pode contribuir para que as pessoas que ali habitam fiquem alheias aos acontecimentos históricos.

Isso se pode notar pelo comportamento dos aldeões, que parecem não se orientar pela racionalidade e ainda viver numa espécie de mundo delimitado, que talvez possa ser caracterizado como arcaico. Nesse tipo de sociedade (e mentalidade) "arcaica", de "pensamento selvagem" 33 as práticas da escrita e das técnicas modernas não são cumpridas, por isso, na maioria das vezes, essas sociedades baseiam suas atividades e suas tradições na oralidade. De fato, na comunidade de Vilamaninhos a comunicação se estabelece basicamente de forma oral, pois grande parte dos aldeões são semianalfabetos.

\footnotetext{
${ }_{32}^{31}$ ELIADE, Mircea. Mito e Realidade. 6. ed. São Paulo: Martins Fontes, 2004, p. 22.

${ }^{32}$ Ibidem, p. 36.

${ }^{33}$ LEVI-STRAUSS, Claude. O pensamento selvagem. São Paulo: Nacional, 1976.
} 
Esse tipo de sociedade "concebe o mundo que a cerca como um microcosmo. Nos limites desse mundo fechado começa o domínio do desconhecido, do não formado." ${ }^{34}$ No caso do texto de Lídia Jorge, ele oferece ao leitor pistas de que há, na aldeia, um desconhecimento no que se refere ao que está externo à vila, o que pode contribuir para o não desenvolvimento da consciência daqueles aldeões. Trata-se de uma aldeia em condições precárias em vários aspectos (cultural, político, social) e isso já pode ser observado na forma como ela é descrita geograficamente: "no meio do redondo mais íntimo sempre fica Vilamaninhos, colado às esferas pelas bordas da terra, cozida de quietude. Mansidão." ${ }^{35}$

Eliade também admite que há relações íntimas existentes entre o mito em si e o tempo, porque o mito é capaz de fornecer revelações sobre a estrutura do tempo. Sendo assim,

um mito narra acontecimentos que se sucederam in principio, ou seja, "no começo", em um instante primordial e atemporal, num lapso de tempo sagrado. Esse tempo mítico ou sagrado é qualitativamente diferente do tempo profano, da contínua e irreversível duração na qual está inserida nossa existência cotidiana e dessacralizada. ${ }^{36}$

Em outras palavras, pode-se supor, então, que o mito acontece em um tempo que transita por um espaço infinito de tempo, um tempo incapaz de ser medido. Nesse caso, como observou Eliade,

um mito retira o homem de seu próprio tempo, de seu tempo individual, cronológico, "histórico" - e o projeta, pelo menos simbolicamente, no Grande Tempo, num instante paradoxal que não pode ser medido por não ser constituído por uma duração. O que significa que o mito implica uma ruptura do Tempo e do mundo que o cerca; ele realiza uma abertura para o Grande Tempo, para o Tempo Sagrado. ${ }^{37}$

Há indícios de que o episódio da cobra, que constitui o foco da trama de O Dia dos Prodígios, contribui significativamente para que ocorra essa "ruptura do Tempo e do mundo que o cerca", pois essa serpente prodigiosa (capaz até de voar), produto da imaginação do povo do vilarejo, reveste-se de sobrenatural e pode ser considerada,

\footnotetext{
${ }^{34}$ ELIADE, Mircea. Imagens e símbolos. Ensaios sobre o simbolismo mágico-religioso . São Paulo: Martins Fontes, 1991, p. 34

${ }^{35}$ JORGE, Lídia. O dia dos prodígios. Rio de Janeiro: Nórdica, 1984, p. 35.

${ }^{36}$ ELIADE, Mircea. Op. cit. p. 54

${ }^{37}$ Ibidem.
} 
nesse sentido, a responsável por introduzir o "mistério no quadro da vida real" ${ }^{38}$ A partir do que se lê no romance, antes do aparecimento dessa serpente nada de interessante acontecia e a população da vila "ia ficando um ovo emurchecido. Que fede, gorado, e não gera" ${ }^{\text {39 }}$. Porém, vale dizer que, nos aldeões, havia, provavelmente, uma predisposição para habitarem esse "Tempo Sagrado", pois viviam alheios ao contexto da história real.

A serpente surge no vilarejo como um "fantasma palpável", mas escorrega por entre os dedos de Jesuína Palha, como se deslizasse através do tempo. Esse súbito desaparecimento causa certo pavor no povo do vilarejo, "A gente agora vai andando, e vê a bicha. Pranta-se o pé e acha-se a bicha. Toca-se a cara e sente-se a bicha. E eu?

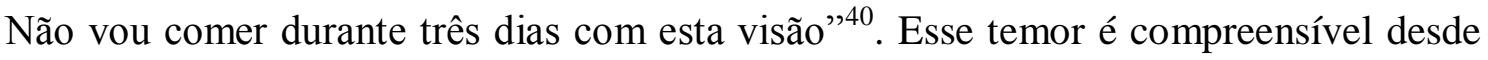
que se leve em consideração a descrição que Chevalier e Gheerbrant ${ }^{41}$ fazem da cobra: "Grande Serpente Invisível, causal e atemporal, senhora do princípio vital e de todas as forças da natureza". Há fortes evidências de que se trata de um acontecimento extraordinário, que muda completamente a vida daquele pequeno e muito peculiar grupo de pessoas.

O aparecimento da cobra parece causar, também, nos habitantes da vila uma sensação de que estão em perigo, como se ela anunciasse a eventual irrupção, a qualquer instante, de algo ameaçador. É essa expectativa que faz criar um ambiente ficcional com as características do fantástico:

Carminha Rosa acordou várias vezes durante a noite. Era um leve bater de postigo. Depois uma telha tinindo na outra. Um conhecimento imperfeito, mas autêntico, de que alguma coisa andava às apalpadelas pela casa. Sem ser gente. Nem vento, nem chuva ${ }^{42}$.

A imagem da serpente, considerada um arquétipo fundamental ligado às fontes da imaginação e da vida, funde-se agora no dragão: "saíram-lhe duas asas dos flanquinhos, como uma fantasia de circo. Só que aquilo era tudo vardade o que a gente víamos. Com os nossos próprios olhos" ${ }^{\text {43 }}$. Cria-se uma atmosfera de suspense em torno

\footnotetext{
${ }^{38}$ TODOROV, T. Introdução à literatura fantástica. São Paulo: Perspectiva, 2004, p. 32.

39 JORGE, Lídia. O dia dos prodígios. Rio de Janeiro: Nórdica, 1984, p. 21.

${ }^{40}$ Ibidem, p. 27

${ }^{41}$ CHEVALIER, Jean; GHEERBRANT, Alain. Dicionário de símbolos: mitos, sonhos, costumes, gestos, formas, figuras, cores, números. 19. ed. Rio de Janeiro: José Olympio, 2005, p. 815.

42 JORGE, Lídia. Op. cit. p. 95.

${ }^{43}$ Ibidem, p. 25.
} 
desse episódio da cobra, e esta atmosfera, como afirma Todorov ${ }^{44}$, era o que havia de mais importante, pois o critério definitivo de autenticidade do fantástico não é a estrutura da intriga, mas a criação de uma impressão específica em função da intensidade emocional que esse elemento fantástico provoca.

Observa-se que o momento da transformação da cobra em um dragão alado pode remeter a uma experiência desse tipo, pois se trata de um acontecimento inusitado, que desperta, nos habitantes daquele vilarejo, reverência e uma mescla de temor e respeito por algo que se mostra superior a eles (divindades e forças sobrenaturais) e ao seu entendimento. Isso pode ser percebido na atitude de Jesuína Palha: "Quando vi a víbora cegui os olhos. Alavanti a saia, brandi a cana, uma, duas, três, sete e vinte vezes sobre a cabeça da bicha" 45 .

Por todos esses aspectos destacados, é possível considerar o episódio da cobra como significativo da presença, nos aldeões, de uma mentalidade mítica, em que o tempo é regido pela natureza, pelas sensações, acompanhando as estações do ano, num movimento cíclico, implicando, também, um constante retorno. De acordo com Scholes, esse movimento lembra o ritual da fertilidade das sociedades primitivas, em que

o tempo é encarado antes que tudo como uma maneira de dividir o ano individual em lugar de um acúmulo de anos sucessivos. O ano é dividido pelos equinócios e solstícios que marcam a evolução anual do sol através dos céus e servem como indicadores de variações sazonais na chuva, temperatura e outros fenômenos naturais associados ao ciclo da vida vegetativa. ${ }^{46}$

De fato, a ação no romance, ocorre no verão (na Europa, esta estação corresponde aos meses de junho, julho e agosto), quando Jesuína se empenha em matar a cobra. O outono é anunciado quando o narrador diz: "Finalmente alguém sentiu que setembro estava a chegar. [...] Sente-se um sopro de outono"47. A primavera foi anunciada quando Maria Rebôla, a dona do bar, abriu a porta da igreja "E deus fez vir o sol para aquecer o piolho da gente. As terras, vizinhos que se danem. Cresça o restolho. E isto é pela primavera" ${ }^{\prime 4}$.

Trata-se do tempo natural, em que o mundo é regido pelas forças da natureza. Os fenômenos naturais exercem, então, uma influência sobre as personagens: "O sargento.

\footnotetext{
${ }^{44}$ TODOROV, T. Introdução à literatura fantástica. São Paulo: Perspectiva, 2004.

${ }^{45}$ JORGE, Lídia. Rio de Janeiro: Nórdica, 1984, p. 22

${ }^{46}$ SCHOLES, Robert \& KELLOG, R. A natureza da narrativa. São Paulo: McGraw-Hill, 1977, p.155

${ }^{47}$ JORGE, Lídia. Op. cit. p. 48

${ }^{48}$ Ibidem, p. 114.
} 
Teria sido anunciado pelas chuvas. E as chuvas anunciadas pelas moscas e pelo soldado. Mas as moscas, o soldado, a chuva, o vento e o sargento, [...] Tudo foi anunciado pela cobra". 49

Esse caráter cíclico do tempo acompanha a ambientação mítica e é tratado por Massaud Moisés ${ }^{50}$ como tempo metafísico ou mítico, estando ligado a um tempo ontológico, no qual o importante é refletir sobre o ser. Trata-se, ainda de acordo com Moisés, do "tempo de todos, não de um indivíduo, tempo da Humanidade, quando era só corpo fundido às coisas do Mundo, tempo reversível em circularidade perene, tempo primordial, [...] tempo sacro, tempo eterno, sem começo nem fim". 51

Assim, constata-se que a ação se passa num passado remoto. E isto é o que parece dar sentido à vida dos que habitam em Vilamaninhos, pois, de certa forma, estão alheios ao mundo, perdidos num ponto do passado, afastados, cada vez mais, do presente histórico. O episódio em que os soldados adentram o vilarejo a fim de colocar os aldeões a par da Revolução dos Cravos pode evidenciar quão afastados estavam do presente histórico.

Sob o ponto de vista histórico, a Revolução causou em Portugal uma grande transformação nos diversos setores políticos, econômicos e sociais. No que concerne a Vilamaninhos, observa-se que a revolução não teve o mesmo efeito, pois se trata de uma vila do interior do Algarve que parece não ter evoluído na mesma proporção em que as transformações ocorreram em Portugal; ao contrário, permaneceu estagnada e sem perspectiva de progresso. Em síntese, a maneira como o povo de Vilamaninhos percebeu a revolução mostra que estão alheios ao mundo que os cerca.

A notícia acerca da revolução chega primeiramente através do único meio de comunicação disponível na vila, o rádio de Pássaro Volante (um dos personagens mais velhos do vilarejo) e, também, através das palavras de Maria Rebôla, dona do bar, ao comentar: "em Lisboa os soldados fizeram uma revolução para melhorarem a vida de toda aquela gente? Uma re vo lu ção?"52.

No final do romance, os soldados chegam à aldeia e anunciam aos habitantes que havia acontecido uma revolução. Ao receberem a notícia, com pouca capacidade para compreender o quanto aquele fato contribuía para o progresso de toda a sociedade, os vilamaninhenses acreditaram que os soldados estavam ali por qualquer razão menos

\footnotetext{
${ }^{49}$ JORGE, Lídia. . Rio de Janeiro: Nórdica, 1984, p. 124.

${ }^{50}$ MOISÉS, Massaud. A criação literária. Prosa. São Paulo: Cultrix, 1985.

51 Ibidem, p. 109.

${ }^{52}$ JORGE, Lídia. Op. cit. p.133.
} 
para anunciar uma revolução. Desse modo, enquanto toda a nação portuguesa lutava pelos seus ideais, os camponeses "dormiam e faziam baracinha como se nada fosse"

Para os habitantes do vilarejo, os soldados ali presentes eram seres de outro planeta, enviados do céu. Tanto que Jesuína diz: "Vem ai um carro. Um carro celestial. Celestial. Olhem todos. Traz os anjos e os arcanjos [...] Vamos ser visitados por seres saídos do céu, e vindos de outras esferas. Onde os séculos têm outra idade". ${ }^{4}$

Neste caso, os aldeões acreditam que os soldados estão ali para talvez explicar o desaparecimento da cobra-dragão e para colocar fim em todas as aflições pelas quais haviam passado por conta do desaparecimento do réptil. Desse modo, a ideia de Revolução, para os habitantes daquela vila, era apenas "assombração" ou "ilusão de sentidos",55.

Ao que parece, a autora coloca o leitor diante de uma história aparentemente comum, mas que se origina no seio de uma cultura mítica. Nesta história há um momento de ruptura, que chama as personagens desta narrativa para a realidade: a Revolução dos Cravos. Mas, frente à revolução, Lídia Jorge promove a mitologização da história, ou seja, cria, a partir de um fato histórico, sua própria mitologia e isto provoca o exagero da experiência cotidiana alicerçada na imaginação mítica. Por conta disso, os aldeões não chegaram a reconhecer o momento histórico em que supostamente estavam inseridos e acabam vivenciando um tempo mítico.

Nunes afirma que não há um tempo mítico, pois "o mito, história sagrada do cosmos, do homem, das coisas e da cultura, abole a sucessão temporal" ${ }^{156}$. Por outras palavras, a ausência dessa sucessão temporal sugere um tempo único, e, no que se refere à obra de Lídia Jorge, independentemente do que ocorre com os habitantes do vilarejo e das ações que eles praticam, o que se conta será sempre produzido neste tempo único, que pode remeter à circularidade, como se não tivesse marcação de início ou tampouco de fim.

Pelo que se percebe, o surgimento e desaparecimento da cobra; a chegada dos soldados ao vilarejo para anunciar a Revolução são acontecimentos que, provavelmente, deram grande contribuição para reforçar ainda mais o pensamento mítico que já se instalava na mentalidade dos vilamaninhenses. Evidentemente, o tempo presente na

\footnotetext{
53 JORGE, Lídia. . Rio de Janeiro: Nórdica, 1984, p. 141.

${ }^{54}$ Ibidem, p. 152.

55 Ibidem, p. 162.

${ }^{56}$ NUNES, Benedito. O tempo na narrativa. 2. ed. São Paulo: Ática, 1995, p. 66 (Série Fundamentos).
} 
narrativa parece ser um grande aliado para reforçar com mais ênfase o primitivismo e o arcaísmo que se fazem presentes naquele espaço.

Nesse ambiente propício à estagnação, ao pouco desenvolvimento no que se refere ao conhecimento do mundo exterior ao vilarejo e, possivelmente, à formação de uma identidade, as personagens se mostram propensas ao não reconhecimento de si. Pelo que a narrativa nos mostra, acredita-se que isso se dá com toda a comunidade de Vilamaninhos, mas, com as personagens femininas, essa falta de consciência de si parece se evidenciar ainda mais. Talvez isso se deva ao fato de a mulher ser considerada, de acordo com a visão da sociedade patriarcal (sociedade vigente na época em que se passa o romance), inferior em relação à figura masculina, o que pode ser observado pelo modo como a narrativa se apresenta e, prioritariamente, pelo comportamento das personagens.

As linhas de $O$ dia dos prodígios são habitadas por certas personagens que merecem destaque na narrativa. Há indícios de que se trata de personagens estereotipadas, que podem vir caracterizadas pela posição em que se encontram relativamente aos eventos narrados e também pelas suas relações recíprocas, concordantes ou conflitantes.

Pelos elementos que são apresentados na narrativa, o leitor, ao mergulhar na leitura do romance, se depara com personagens que talvez possam ser consideradas autênticas representantes das classes oprimidas portuguesas. Essa impressão se instala a partir do reconhecimento de que se trata de um universo formado essencialmente por mulheres, e também pela época em que se passa a narrativa (época da ditadura salazarista, em que as mulheres eram classificadas como seres menores estabelecendo uma relação de dependência com a figura masculina e, consequentemente, vivendo momentos intensos de opressão).

Além de mulheres oprimidas, Vilamaninhos também é habitada por idosos e crianças, vivendo isolados no vilarejo, espaço situado imaginariamente na região do Algarve. Dedicando seu tempo aos afazeres domésticos e aos trabalhos rurais, grande número dessas personagens pode representar, e isso é perceptível na ação narrada, o retrato da opressão. As mulheres não tinham nenhum poder de decisão e os idosos que ali habitavam eram como que inválidos, já que não desenvolviam nenhuma função nem apresentavam condições físicas para servirem à pátria participando dos combates nas colônias portuguesas. 
Trata-se de um período em que Portugal estava vivendo a Guerra Colonial e, sobre essa questão (período que durou de 1961 a 1975), vale ressaltar que grande parte, senão todos, dos homens jovens estavam lutando na Guerra em prol da pátria portuguesa. Na realidade, de acordo com Pinto ${ }^{57}$, desde o século XIX, as guerras coloniais, para a recriação e a manutenção do Império Ultramarino, exigiram a constante presença militar portuguesa na África, ampliando em muito essa condição histórica que ligou os jovens da nação, por longo período de suas vidas, às armas portuguesas. Sendo assim, só não participavam da guerra aqueles que não tinham realmente condições, por serem idosos ou por apresentarem algum tipo de problema.

Em função da Guerra Colonial, Portugal, naquele momento, tornou-se basicamente um país constituído por mulheres. Naquele período, como afirma Tavares, "o sofrimento dessas mulheres ia-se apaziguando com as cartas que chegavam por correio, mas o tempo de espera era demasiado $[\ldots]^{58} \mathrm{O}$ regresso era aguardado com muita ansiedade, mas as tensões acentuavam-se no retomar da vida em comum."59 Diante dessa situação, as mulheres, sem alternativa, acabavam exercendo não somente as funções dentro do lar, mas também fora dele.

Em se tratando de $O$ dia dos prodígios, grande parte das mulheres que habitavam a aldeia exerciam também trabalhos braçais, nos campos, para garantirem o sustento próprio e também o da família. Cada uma desenvolvia, a sua moda, as suas funções dentro e/ou fora do espaço doméstico. Umas eram mais comedidas e centradas nas tarefas do interior da casa, outras, mais proativas, responsabilizavam-se pelos trabalhos externos, plantio e colheita, para garantir o abastecimento da vila. Importante dizer que, pelo que mostra a narrativa, todo tipo de trabalho era desenvolvido basicamente pelas mulheres, porque os homens que ali estavam não tinham condições para desenvolvê-lo.

No que se refere às personagens, pode-se considerar, em primeira instância, que parece possível dividi-las em dois núcleos. O primeiro grupo parece estar caracterizado por um nível de consciência inferior. Neste se podem incluir as personagens Jesuína Palha, o casal Esperancinha Tereza e José Jorge Junior, e os demais personagens que

\footnotetext{
57 PINTO, Antonio Costa. O fim do império português: a cena internacional, a guerra colonial, a descolonialização (1961-1975). Lisboa: Livros Horizonte, 2001.

${ }^{58}$ TAVARES, Manuela. Anos 60, os ventos para uma nova vaga dos feminismos não chegam a Portugal. In: Feminismos: percursos e desafios (1947-2007), p. 131.

${ }^{59}$ Ibidem.
} 
habitam no vilarejo, divisão baseada nas atitudes e posicionamentos que essas personagens tomam diante dos acontecimentos sucedidos no vilarejo.

O segundo grupo se compõe de personagens que se mostram num estágio de consciência um pouco mais elevado em relação ao primeiro grupo, no qual se podem incluir as personagens Branca Volante, Carminha Parda e Carminha Rosa, e Macário. Esse indício de elevação no nível de consciência parece estar associado a ações específicas praticadas por essas personagens - o bordar e o limpar, respectivamente, ações consideradas tipicamente femininas e ainda constituem atividades essencialmente intuitivas, que convidam ao mergulho na interioridade e, consequentemente, a um desenvolvimento, mesmo que involuntário, de uma consciência de si. Acredita-se que, talvez, Carminha Rosa (mãe de Carminha Parda) possa ser inserida neste grupo porque convive com o drama de ter se relacionado com o padre da cidade (Carminha Parda é fruto desse relacionamento) e, pelo que se nota, não sente vergonha por isso.

Macário, embora não esteja inserido no rol das personagens femininas, merece atenção especial porque, assim como Branca e Carminha Parda, exerce uma atividade manual, toca violão e, além disso, canta e compõe. Macário se mostra, na narrativa, como um artista, poeta e, por meio da composição de poesias, acredita-se que há possibilidade de um mergulho no seu íntimo e um provável reconhecimento de si. Pelo que parece, essa personagem se apresenta dotada de uma inquietude que seria própria daqueles que, ainda que vivendo num universo indiferenciado, se destacam por um olhar iluminado.

No primeiro grupo de personagens, José Jorge Junior e Esperancinha Tereza formam um casal que parece simbolizar a estagnação e o arcaísmo que no vilarejo se instala. Isso pode ser notado pelo comportamento dessas personagens e pela forma como são descritos na narrativa.

José Jorge Junior, entre as personagens mais antigas da narrativa, "Contava oitenta e sete e vinha do outro século. Muitos anos mais velho do que sua mulher. E, no entanto, tinha ele forças e memória."60 A força de José Jorge é tão posta em evidência na narrativa que o significado de seu nome faz alusão ao Santo Guerreiro, São Jorge:

Ao avô do avô desse meu avô, que comigo andou no colo, [...] um dia dizem que ele estava a comer uma alfarrobinha seca, [...] e alguém lhe disse. Está ali uma cobra [...] Nessa altura esse José pegou numa varinha que ali se encontrava arrumada à parede, foi ao buraco donde

\footnotetext{
${ }^{60}$ JORGE, Lídia. O dia dos prodígios. Rio de Janeiro: Nórdica, 1984, p. 28.
} 
a diaba espreitava os passantes, e desencantou a bicha, [...] Ora a velha. Que tinha idade para ser trisavô dele. Vendo que o rapaz que ela tinha criado com caldinhos de leite, tinha morto o animal, dizem que disse. Ah José. Tu és parente do São Jorge, meu filho. E eu te pranto esse nome. E assim José Jorge [...] gerou a Manuel Jorge. E Manuel Jorge gerou a José Jorge. E José Jorge a Manuel Jorge que foi meu avô, e meu avô, Esperancinha, gerou a José Jorge que foi meu pai, que me gerou a mim, e me botou o seu nome, igual, mas pôs Júnior também, que significa menino. ${ }^{61}$

A semelhança existe porque tanto a personagem quando o santo guerreiro têm natural índole combativa, e essa coragem foi atribuída a José Jorge Junior porque herdou o nome - e também a valentia - de seu bisavô. Mas, para José Jorge Junior, restara apenas a memória, porque, na condição de idoso, a força lhe faltava.

Lídia Jorge parece querer mostrar os traços do heroísmo português, perceptíveis em alguns personagens masculinos que, apesar de fragilizados pela velhice, ainda estão revestidos por certo heroísmo. Isso ocorre com José Jorge e também com Pássaro Volante, personagem que será apresentada oportunamente. Esse heroísmo vem atrelado à religiosidade; no caso de José Jorge, primeiramente por conta do nome dado a seu bisavô, que por consequência acabou sendo batizado pelo mesmo nome, aludindo a São Jorge guerreiro. O bisavô, ao destruir corajosamente a cobra, personificada na figura de um dragão, ganha não somente méritos de herói, mas do arcanjo salvador que destruiu a serpente. Com isso, a narrativa oferece indícios de que elementos do fantástico e do religioso se misturam.

Nota-se ainda, na história dos antepassados de José Jorge e, consequentemente, na sua própria trajetória, outro traço do religioso, quando a narradora cita que seu bisavô foi encontrado dentro de um cesto pela senhora que o criou, assim como Moisés também é encontrado dentro de um cesto. Como Jesus, José também é batizado quando se torna adulto, mas neste caso trata-se de um segundo batismo: "Ah José. Tu és parente

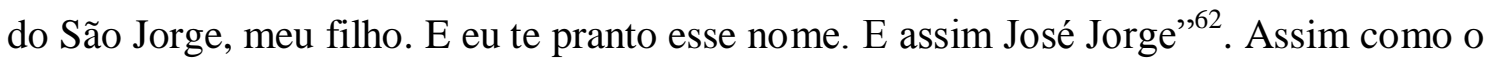
santo guerreiro, o antepassado de José Jorge destruiu o mal, a cobra. Aliás, na Bíblia a serpente e o dragão são dois animais que têm conotação negativa, ou seja, representam a crueldade, a destruição e, muitas vezes, são fundidos em um só, tornando-se serpentes aladas.

Em Vilamaninhos, parece que a serpente voadora incide enquanto arquétipo do mal correlacionado com as representações do bem, não somente no tempo como no

\footnotetext{
${ }^{61}$ JORGE, Lídia. Rio de Janeiro: Nórdica, 1984, p. 29-31.

${ }^{62}$ Ibidem, p. 30.
} 
espaço míticos da narrativa, "atrasado e telúrico"63. De acordo com Bidermann ${ }^{64}$, a serpente pode representar o mundo infernal, por construir "seu habitat" nas profundezas da terra e, por decorrência, no reino dos mortos; paradoxalmente, liga-se à ideia de rejuvenescimento, indiciado pela periódica "troca de pele". ${ }^{65}$ Essa dicotomia Bem x Mal se faz presente no vilarejo, e a serpente tem uma conotação negativa quando é exterminada heroicamente, primeiro pelo bisavô de José Jorge e segundo por Jesuína Palha. Quando se transforma em dragão, a conotação negativa perdura porque a simbologia cristã, como registra Chevalier ${ }^{66}$, considera o dragão como escarnação do demônio, ou de Lúcifer, vencido pelo arcanjo Miguel e lançado ao Inferno. Por esse motivo, os dragões são muitas vezes associados ao elemento fogo. Diz a Bíblia Sagrada que, por causas celestes, "Miguel e seus anjos tiveram de combater o Dragão. O Dragão e seus anjos travaram combate, mas não prevaleceram. E já não houve lugar no céu para eles." 67

Em $O$ dia dos prodígios o arcanjo Miguel, assim como São Jorge, podem estar representados também na figura do bisavô de José Jorge e, por extensão, no marido de Esperança Tereza. Quando Lídia Jorge faz alusão a esses heróis bíblicos, ícones da coragem, da força e do bom exemplo, ela, metaforicamente, parece atribuir as mesmas características a José Jorge e a seus antepassados. De fato, a narrativa aponta que José Jorge é ex-combatente da Guerra Colonial e deve ter enfrentado muitos "dragões" nos combates de que participou, o que acaba revestindo-o de uma aura de valentia e força, que, pela sua forma física e idade, já não existem mais. Mesmo assim, José Jorge ainda se sente encorajado e atribui a si mesmo qualidades que possuía na sua mocidade.

Além disso, outro traço de religiosidade presente na personagem José Jorge se apresenta quando revela, num determinado momento da narrativa, seu interesse por escrever parábolas do evangelho. Isso é mostrado no texto no momento em que é mencionada a falta de água no vilarejo e José Jorge usa a parábola dos talentos e o exemplo dos lírios do campo, que não precisam fazer nada para serem providos pelo senhor. No texto bíblico do livro de Matheus, consta a seguinte passagem: "Olhai as

\footnotetext{
63 JORGE, Lídia. Rio de Janeiro: Nórdica, 1984, p. 16.

${ }^{64}$ BIDERMANN, Hans. Dicionário ilustrado de símbolos. São Paulo: Melhoramentos, 1993.

${ }^{65}$ Ibidem, p. 344-345.

${ }^{66}$ CHEVALIER, J. \& GHEERBRANT, A. Dicionário de simbolos. Mitos, sonhos, costumes, gestos, formas, figuras, cores, números. 19. ed. Rio de Janeiro: José Olympio, 2005, p. 815.

${ }^{67}$ Apocalipse, 12, 7-8. In: Bíblia Sagrada.
} 
aves do céu; não semeiam nem ceifam, não recolhem nos celeiros e vosso Pai celeste as alimenta. [...] Considerai como crescem os lírios do campo; não trabalham nem fiam" ${ }^{68}$

José Jorge, ao fazer alusão à parábola, mostra que não é preciso preocupar-se com os problemas. Como diz no livro de Matheus, "são os pagãos que se preocupam". ${ }^{6}$ Sendo assim, ele não se afligia porque se considerava também um homem de fé e credor nas palavras do Senhor. Mostrava-se religioso, frágil fisicamente devido à idade já avançada, mas não hesitava em colocar sua esposa Esperança Tereza sempre em uma condição menor:

Havia mais de dez anos que ela se decompunha em vida pela casa. Se transformava em poeira antes da morte. Cheirava a isso por toda a parte. Tão forte que só tapando o nariz. Custa a crer, Esperancinha. E fazia o gesto. Alguma vez ouvira ela falar do alfabeto e das orações? Tinha esquecido tudo o que deveria estar guardado na casa da memória. Mas eu. Oh eu. José Jorge Júnior continuava a escrever. ${ }^{70}$

Para José Jorge, Esperancinha praticamente não existia; já ele, na sua própria visão, era ainda dotado de boas qualidades. Há, portanto, uma contradição, porque um homem religioso e seguidor dos preceitos do Senhor jamais poderia sentir-se superior ao outro, fosse ele quem fosse. Além disso, não deveria maltratar a esposa, pois essa ação não se enquadra numa conduta religiosa. Esperancinha Tereza, sim, parece ter uma boa conduta religiosa. Trata-se de uma mulher idosa que, ao que parece, dedicou-se desde sempre aos filhos e ao marido.

Esperança Teresa falava punhões e caragos, levantava objecto do chão. Ela própria na hora achada oportuna, tinha sabido desistir. Muda e lenta como um caracol, aquecia água pela manhã, deslizando uma mão pela parede. Mas as manobras de alcançar, poisar, desembrulhar o pão. Ainda parti-lo e migá-lo. Ocupavam-lhe o tempo. Muito e todo. Chegava a dar de café à hora em que os demais comiam o almoço. ${ }^{71}$

Esperança pode simbolizar a mulher oprimida, que não consegue, em nenhuma hipótese, afastar seus pensamentos das atividades domésticas. Mesmo diante do sumiço da cobra, acontecimento que abalou grande parte dos habitantes do vilarejo, Esperança permanece envolta em suas lembranças:

Esperança Teresa limpou as mãos no avental sem participar dos espantos. Ah gente, porca e calhandreira, nem escapam os bichos do monte. Verificou se a tampa da cisterna estaria baixada sobre a boca, não fosse a pobre ter a ideia de vir apodrecer na pouca água do seu

\footnotetext{
${ }^{68}$ MATHEUS: 6: 26-29, p. 1290 In: Bíblia Sagrada.

${ }^{69}$ Ibidem.

${ }^{70}$ JORGE, Lídia. O dia dos prodígios. Rio de Janeiro: Nórdica, 1984, p. 28.

${ }^{71}$ Ibidem, p. 28.
} 
depósito. Mil vezes antes mergulhar nas cogitações da sua vida passada. Sempre à Mao da lembrança. Longa e dulcificada. ${ }^{72}$

Esse "mergulho na vida passada" pode sugerir que Esperança talvez se sinta mais à vontade assim porque a realidade em que vive não lhe oferece perspectivas de um futuro melhor. Nota-se que a personagem é apresentada como uma mulher submissa, sem predicados e tampouco utilidades, pois, na visão do marido, seu destino é cuidar da casa e dos filhos. Sendo assim, para ela, relembrar o passado seria a melhor alternativa já que, no presente, suas atitudes e sua própria pessoa parecem ser consideradas desprezíveis.

Na realidade, a maior ocupação de Esperancinha, para não dizer a única, era primeiro parir filhos e depois cuidar deles. A mulher de José Jorge fala sobre os filhos, nomeando um a um, e também fala daquele que nasceu morto, que não é nomeado.

E eu doze vezes di a luz, José. Tu te alembras? Doze vezes. Primeiro foi o Manuel. Depois veio a Engrácia. Depois o Saul. Depois o Eloi. Depois o Bento. Depois do Augusto julgui não poder conceber. Mas eram coisas passadoiras. Mistérios da barriga. Um dia fiqui do Antônio. Depois do Marçal, e do Duarte. E do Simão. Depois do morto. [...] Chegou como os demais, cheiinho de sebo e sangue. Mas morto. [...] deus já o tinha chamado Serafinzinho. Nunca a gente lhe viu os olhinhos abertos. ${ }^{73}$

Mesmo tendo dado a luz a vários filhos, Esperancinha se lamenta da perda de um. Ao que parece, a personagem se sente impotente por ter perdido um filho, como se atribuísse a si própria alguma culpa pelo fato de a criança não ter vingado. Na realidade, a mulher quase sempre era julgada quando algo não saía bem, principalmente, se o fato tivesse ocorrido no âmbito domiciliar. Aos olhos da sociedade, a perda de um filho, fosse qual fosse o motivo, e em grande parte das ocasiões, era culpa da mulher. Além disso, o discurso, a opinião, a voz feminina era sempre ignorada. Em se tratando de Esperancinha, nada que era dito por ela seu marido levava em consideração, ele sequer a ouvia. Mas fazia questão de que ela ouvisse e ficasse atenta ao que ele discursava: "Chega-te aqui Esperancinha, senta-se nessa cadeira e tira o lenço da cabeça para ouvires o que ainda me lembro sobre a gente dos meus passados. Oh Esperancinha o avô do avô desse meu avô, que comigo andou ao colo, nasceu das ervinhas" ${ }^{74}$

\footnotetext{
${ }^{72}$ JORGE, Lídia. Rio de Janeiro: Nórdica, 1984, p. 29. Grifos nossos.

${ }^{73}$ Ibidem, p. 29-32.

${ }^{74}$ Ibidem, p. 29-30.
} 
Na realidade, a mulher de José Jorge não o ouvia. Enquanto ele estava envolto nas lembranças dos seus antepassados, ela voltava sua memória para a lembrança do nascimento dos filhos. Eram verdadeiros monólogos que se caracterizavam como discursos totalmente solitários. Mas, mesmo estando com sua mente ocupada por outros pensamentos, Esperancinha estava ali, diante de seu marido, de corpo presente, supostamente ouvindo as histórias de José Jorge, porque jamais poderia deixar de obedecer a ele.

Isso provavelmente era reflexo da situação da mulher da época (em que as pessoas viviam sob um regime de ditadura e a mulher não tinha voz ativa). Ela representava a obediência, a submissão e a servidão. Além disso, deveria estar sempre atrelada a uma figura masculina que ordenava seu destino; no caso de Esperança, esse papel era desempenhado por José Jorge. Mas este não contribuía somente para Esperança manter-se na opressão.

Pelo que parece, indiretamente, ele contribui também para que ela mergulhe no seu interior e, talvez, faça uma revisão de si, pois de acordo com Holquist ${ }^{75}$, o indivíduo só se constitui na relação com o outro. A relação que se estabelece entre o casal parece não contribuir significativamente para o reconhecimento interior de Esperancinha. Mas somente o fato de essa relação proporcionar a ela a possibilidade de visita no seu íntimo (e isso é mostrado quando ela deixa transparecer suas preferências "Mil vezes antes mergulhar nas cogitações da sua vida passada" (JORGE, 1982, p. 29)), pode ser o indício de que talvez possa haver, não exatamente naquele momento, uma possível conscientização de si. É provável que haja uma esperança de que talvez, num futuro distante, algo possa se transformar em Esperancinha.

$\mathrm{O}$ nome atribuído à personagem sugere uma transformação. $\mathrm{O}$ vocábulo esperança, de acordo com Houaiss apresenta alguns significados, dentre eles: "1. Sentimento de quem vê como possível a realização daquilo que deseja. [...] 3. Expectativa, espera. [...] 5. Algo que não passa de uma ilusão."76 Esses significados talvez possam ter alguma relação com o comportamento da personagem já que a espera e a expectativa de que algum desejo se realize pode ser considerado (tendo em vista a situação pela qual a figura feminina se encontra devido ao contexto em que está inserida) como algo que faz parte daquele universo de repressão. Por outro lado, sabe-se que a palavra "esperança" pode ter também um significado bíblico. Nesse viés, a

\footnotetext{
${ }^{75}$ CLARK, Katerine; HOLQUIST, Michael. Mikhail Bakhtin. São Paulo: Perspectiva, 1998.

${ }^{76}$ HOUAISS, Antônio. Dicionário da Língua Portuguesa. Rio de Janeiro: Objetiva, 2001, p. 1228.
} 
expectativa que compõe o significado da palavra que foi atribuída como o nome da personagem em questão pode expressar confiança, mas esperar requer disciplina.

Isso pode ser notado, ao que tudo indica, na primeira ocorrência da palavra “esperança”, em Gênese 8:14, ligada à vida de Noé: "Soltou também uma pomba, para ver se as águas teriam já diminuído na face da terra. A pomba, porém, não encontrando onde pousar, voltou para junto dele na arca. [...] Esperou mais sete dias, e soltou de novo a pomba fora da arca. E eis que pela tarde ela voltou, trazendo no bico uma folha verde de oliveira. Assim Noé compreendeu que as águas tinham baixado sobre a terra. Esperou ainda sete dias, e soltou a pomba que desta vez não mais voltou".

Noé esperou pacientemente o retorno da pomba trazendo uma folha verdosa em seu bico, simbolizando esperança, até chegar o momento em que o animal não mais retornou e isso pode ser sinal de libertação. A personagem da narrativa, Esperança parece esperar, sem lamúrias relembrando o seu passado. Pode ser que Esperancinha, assim como a pomba de Noé atinja a liberdade, mas essa, pelas linhas que se apresentam na narrativa, parece ser uma possibilidade bastante remota, porque a personagem está diante de um contexto de repressão.

Além disso, carrega também um segundo nome, Tereza, que pode fazer alusão a Santa Terezinha (jovem que desde muito pequena tinha uma incrível fome eucarística e, por isso, aos 16 anos, recebeu o hábito de freira). Assim como Santa Terezinha, Esperança Tereza também passou por muitas provações e suportou a todas calada, sem contestar, aceitando aquilo que lhe fora imposto. Por esse motivo, a personagem, mesmo carregando Esperança em seu nome, parece não alimentar muitas expectativas de que um dia possa se libertar da carga de repressão que a envolve. Seu destino parece mais propenso a aceitar a condição que lhe é imposta, sem margem para revoltas, e permanecer confiante na promessa de salvação, assim como fez Santa Terezinha, mesmo diante das coisas que não gostava, "se precavia para que nada dissesse. Tinha adquirido o bom hábito de nunca se queixar, mesmo quando lhe tiravam o que era seu, ou então quando era acusada injustamente. ${ }^{77}$

Esperancinha Tereza fazia parte da grande maioria das mulheres que se resignavam, mesmo quando ficavam sozinhas em suas casas, sem a presença de uma figura masculina (filho ou marido), porque estes eram convocados a ir para a guerra. Mas, de acordo com Manuela Tavares no seu artigo intitulado: Anos 60, os ventos para

77 Santa Terezinha do menino Jesus e da sagrada face. In: História de uma alma: manuscritos autobiográficos. 30. ed. São Paulo: Paulus, 2013, p. 45. 
uma nova vaga dos feminismos não chegam a Portugal, "O sentimento contra a Guerra Colonial ia crescendo dentro do peito. Nem todas se resignavam. Muitas se empenharam na luta contra a guerra e pelo regresso dos soldados, mesmo quando Abril chegou. Mas muitas outras foram guardando os silêncios." 78 Esperança fazia parte do grupo daquelas que guardavam seus silêncios, sofriam caladas.

Nesse universo, prioritariamente liderado por mulheres, Jesuína Palha se mostra uma líder, cuja função é cuidar e zelar por todos da aldeia. O núcleo liderado por ela abrange a comunidade de modo geral, e Jesuína se vale desse poder para estigmatizar as Carmens por considerá-las pecadoras, a mãe ex-amante de um padre e a filha, fruto desse ato proibido.

Entre as mulheres do romance, essa personagem pode ser considerada como a que remete à valentia e à força; como a porta-voz da comunidade, ela também pode ser vista como a representação da má-língua e de certa audácia. Eliana Berg (1994), em seu ensaio sobre a obra em questão, assinala a superioridade da voz de Jesuína sobre as demais; esta parece fazer questão de propagar o fogo das manifestações coletivas, sempre pronta para reunir o povo em torno de suas crenças de desgraça. Apesar de haver simultaneidade no discurso, em alguns momentos o texto é dividido em colunas, dispondo-se à esquerda a voz de Jesuína e, à direita, fragmentos da voz coletiva, a voz de Jesuína sobrepondo-se. Essa sobreposição está evidenciada no discurso de Jesuína:

Eu andava a dar fogo ao forno quando ouvi estes três desgraçados a pedirem acuda. Mas não deixi que pedissem duas vezes. Pus os tojos de lado, salti por cima da parede, pegui uma cana comprida que ali tinha à mão, e fui-me para onde estes três vai não vai tentavam matála. Sem conseguirem os pobrezinhos. ${ }^{79}$

Da fala de Jesuína pode-se inferir uma relação de dominação dela sobre os aldeões, tal como se vê quando eles pedem ajuda, acreditando que somente uma figura tão poderosa e destemida como ela, assim eleita por eles, seria capaz de resolver todos os problemas. Fica também visível na sua fala a sensação de poder sobre os demais ("os pobrezinhos") e a sua satisfação no desempenho desse papel. Sendo assim, o fato de atender, aparentemente prontamente, ao chamado deles mostra quanto ela subestima a capacidade de ação dos que ali estavam. Essas atitudes de Jesuína Palha são indícios de seu poder de dominação sobre os habitantes do vilarejo e, ao mesmo tempo, conferem-

\footnotetext{
${ }^{78}$ TAVARES, Manuela. Anos 60, os ventos para uma nova vaga dos feminismos não chegam a Portugal. In: Feminismos: percursos e desafios (1947-2007). São Paulo: Leya, 2011. p. 131.

${ }^{79}$ JORGE, Lídia. O dia dos prodígios. 2. ed. Portugal: Dom Quixote, 1982. p. 20.
} 
lhe, ainda nas palavras de Berg, os poderes de uma sibila: "Jesuína aparece como uma sibila, rodeada pelo coro que apoia a sua intervenção". ${ }^{80}$

Acredita-se que, nesse sentido, a palavra "coro" talvez não remeta a um conjunto de cantores apresentando um trecho musical, como se define habitualmente, e, por esse viés, a musicalidade parece ser sinônimo de harmonia. Porém, no romance, esse "coro" pode ser compreendido como uma série de manifestações verbais de várias pessoas ao mesmo tempo e essas não parecem orquestradas, ao contrário, sugerem um grande desentendimento.

Para Oliveira, "o desentendimento existe na multiplicidade de narradores e na mistura de várias pessoas narrativas. Um desentendimento na alternância de discursos e na abundância de diálogos 'desentendidos', semeados sem espaço ou travessão." ${ }^{\text {" Esse }}$ desentendimento pode ser observado ao longo da narrativa, quando os aldeões falam em coro, concomitantemente, sem estabelecerem uma sequência, ocasionando, assim, grande confusão. Isso ocorre também nos "diálogos" entre José Jorge e Esperancinha, em que dialogam sem ouvirem um ao outro.

Apesar das diferentes vozes instauradas no discurso dos aldeões, que remetem à desordem, e à aparente ausência de um líder para gerir esse "coro", as ações de Jesuína mostram a figura da mulher que assume uma posição dominante na comunidade, exercendo autoridade de chefe diante do povo do vilarejo. Além disso, parece dotada de uma energia que pode remeter a uma força telúrica, pois esse tipo de energia que dela emana se assemelha àquela vinda do centro da terra. Uma força capaz de envolver e influenciar aqueles que a cercam. Mas é provável que, fora do ambiente fechado de Vilamaninhos, Jesuína seja considerada socialmente invisível porque, assim como os outros moradores, desconhece os acontecimentos desencadeados no entorno da aldeia.

Embora se mostre líder da comunidade, Jesuína não demonstra ter consciência de seu discurso, portador de certas nuances de incompreensão dos fatores sociais, políticos e culturais condicionantes. Assim como os outros, ela não tomou conhecimento do acontecimento histórico (Revolução de 1974) que deveria envolver toda a sociedade portuguesa. Esse desconhecimento pode manter distanciados da realidade que os cerca, alheios ao exterior da vila, todos os habitantes, não somente

\footnotetext{
${ }^{80}$ BERG, Eliana. $O$ dia dos prodígios: escrita prodigiosa. Revista Colóquio Letras. Ensaio, $n^{\circ}$ 132/133, Abril, 1994, p. 147-156, p. 152.

${ }^{81}$ OLIVEIRA, Anabela B. de. O "desentendimento" do narrador na obra de Lídia Jorge. In: Lídia Jorge Dossier. Letras \& Letras, n. 55, 18 set. 1991, p. 9.
} 
Jesuína. Nesse caso, Jesuína se mostra como uma mulher portuguesa alienada, que se mantém fechada num universo em que talvez nada exterior ao vilarejo penetrará.

Em muitos momentos, Jesuína dirige duras palavras de acusação a Carminha Rosa e Carminha Parda, mãe e filha respectivamente. Carminha Rosa cometeu, aos olhos dos aldeões, um duplo pecado, primeiro porque deu a luz a uma criança sem estar em matrimônio e, segundo, porque essa criança foi fruto de um relacionamento com um padre. Esse acontecimento, na concepção de toda a comunidade, além de ferir os valores da moralidade, desestrutura completamente os pilares daquela sociedade patriarcal, depondo também contra os princípios da igreja católica.

Em razão dos fatos, essas mulheres foram julgadas e condenadas pelos habitantes de Vilamaninhos. Apesar desse mau julgamento, trata-se das personagens, juntamente com Branca Volante e Macário, que aparentam um nível de consciência mais evoluído em relação às outras. Macário acaba sendo enquadrado no rol dessas personagens (mesmo sendo uma personagem masculina) porque deixa transparecer uma alma feminina, pelo seu modo de agir diante de Carminha Parda, deixando transparecer uma mentalidade pouco machista se comparada às outras personagens masculinas.

A respeito de Carminha Parda principalmente, havia rumores e preconceitos, fazendo-a imaginar que, quando algum forasteiro fosse pedi-la em casamento, já prevendo a filiação da moça, diria:

Este dedinho adivinhou. Quando iniciei a caminhada já sabia que o teu pai é incógnito, mas que nesta povoação ninguém ignora quem te gerou. Falam que no baptistério. Aí mesmo, sob as santas imagens e diante da cruz da via sacra. A décima estação dos martírios. Quando nasceste todos quiseram espreitar a tripa do umbigo e a rosinha das coxas, exactamente porque esperava se a mãe natureza pródiga em vinganças. [...] a tua mãe deixou-se assaltar dúzias de vezes ainda sob as figueiras ramudas dos corgos [...] Mas tu sabes [...] que ele abalou de madrugada escarranchado sobre uma mula, levando entre as pernas um baú de paramentos e demais coisas santas. ${ }^{82}$

Para se livrarem desse estigma e pelo desprezo que os aldeões lhes infligem em razão da condição das duas, que consideram pecaminosa, ambas vivem trancadas em casa, mal transitando pelo vilarejo. Carminha, a filha, ocupa-se em limpar constantemente as janelas, como se quisesse limpar de si as impurezas por ser filha de um padre.

${ }^{82}$ JORGE, Lídia. O dia dos prodígios. Rio de Janeiro: Nórdica, 1984, p. 16-17. 
Carminha parecia fazer adeus, mas apenas lavava janelas. Um pano branco na mão. $\mathrm{O}$ braço adejando de encontro ao vidro. Alguidarzinho ajoujado de espuma cremosa. Um alguidar maior de pura água macia. Novelo de saias entre pernas. Cadeira de tabua ajaezada de nódoas, flores vermelhas. Os pés aí juntos no fundo côncavo. As pernas de leve penugem rasinha. Então Carminha empertigava-se de encontro à mancha renitente entre a unha e o vidro. Minúscula, fruto de mosca palhetando asas em tempo vazio, compondo um ovo de esterco redondo. ${ }^{83}$

O movimento da mosca, "palhetando asas em tempo vazio", de certo modo assemelha-se aos movimentos redondos de Carminha ao limpar o vidro, num possível espelhamento que evoca a condição de desnorteio de ambos os "seres" (a mosca e Carminha, que, neste momento, ainda não atingiu o nível mínimo de consciência, de onde a implícita analogia entre ela e a mosca adejando ali perdida). No mesmo fragmento, a referência ao tempo vazio remete à ausência de sentido das ações de ambas - sentido que, se existisse, também projetaria a personagem Carminha no seio da História, mas que, neste momento, não existe.

A referência às moscas permeia o discurso de Carminha e, quando "encontra essas moscas de ventre falido no alto do bordo da janela [...] tira esse lixo imperfeito que lhe macula o rosto da janela" ${ }^{84}$ As moscas, nesse contexto, parecem apresentar uma conotação negativa, pois, se não removesse aquele "lixo imperfeito" dali, sua visão da janela seria atrapalhada. Essa conotação reporta-se às palavras de Chevalier, que trata as moscas como "seres insuportáveis, que se multiplicam sobre o apodrecimento e a decomposição [...] e simbolizam uma busca incessante." ${ }^{~} 85$ Talvez aquilo que, para Carminha, representa algo ruim, incômodo, adjetivos atribuídos às moscas, possa contribuir para que ela comece enxergar para além da vidraça.

Outros animais também são citados quando as características de Carminha Parda são descritas, de maneira que se evidencia uma comparação:

Vê-se no espelho de vidro, Branca e lisa, sem resíduo de fogagem nem impingem. Sobrancelha rala, longe dos olhos escuros, e o escuro dos olhos sobre o azulado do branco, vidrado e transparente como verdadeiro vidro. Cabelo escorrido e pesado como uma cauda de cavalo. Preto, azulado e brilhante, reflexo de uma asa de corvo. ${ }^{86}$

\footnotetext{
${ }^{83}$ JORGE, Lídia. Rio de Janeiro: Nórdica, 1984, p. 11.

${ }^{84}$ Ibidem, p. 12-13.

${ }^{85}$ CHEVALIER, Jean; GHEERBRANT, Alain. Dicionário de símbolos: mitos, sonhos, costumes, gestos, formas, figuras, cores, números. 19. ed. Rio de Janeiro: José Olympio, 2005, p. 623.

${ }^{86}$ JORGE, Lídia. Op.cit. p. 13.
} 
O cavalo, como mostra Chevalier (2005), pode ser associado originalmente às trevas do mundo. "Filho da noite e do mistério, esse cavalo arquetípico é portador de morte e de vida a um só tempo, ligado ao fogo, destruidor e triunfante, como também à água, nutriente e asfixiante." 87 Já o corvo, ainda sob o ponto de vista de Chevalier, seria, dentre outras simbologias, "um símbolo da solidão, ou melhor, do isolamento voluntário [...] Assim, na maior parte das crenças a seu respeito, o corvo aparece como um herói solitário, muita vez demiurgo ou mensageiro divino, guia em todo caso, e, até guia das almas na sua última viagem....

Pelo que se nota na narrativa, voltam-se para Carminha Parda olhares de reprovação, condenação, como se nela estivesse embutido aquilo que remete à treva, a todos os pecados do mundo. Acredita-se que seja um dos motivos que a fazem ser comparada a um cavalo. Por outro lado, essa jovem, estigmatizada por sua filiação e solitária por exclusão, também está equiparada a um corvo. Sob esse prisma, apesar da solidão, Carminha parece tentar reagir a essa situação de reclusa e, por esse motivo, talvez, possa ganhar conotação de heroína porque sobreviver aos insultos e à discriminação impostas a ela e à mãe por Jesuína e o grupo de aldeões, não parece uma tarefa simples.

Acredita-se que, em Carminha Parda, pode haver, mesmo que no subconsciente, uma ânsia por liberdade, com se depreende do fragmento abaixo:

Exactamente por baixo da boca fechada a janela ainda tinha um orifício. Empurrou o pano com o dedo, escarafunchou o desconhecido com a polpa e a unha serrada e trouxe para o rego do peitoril asa e lixo, que sendo de muita cor formavam um todo cinzento e detrital. A frescura da casa, assim preservada pelos batentes da janela clara era um primor. Apetite de andar descalça sobre os ladrilhos vermelhos do chão. Cheiro a coisa lavada no pino do meio dia. Carminha até já viu um casulo donde saiu uma borboleta desenxovalhando as asas e sacudindo o pólen da barriga ainda lagarta. Apetece-lhe estender-se. Mostrar-se e sacudir o pólen da sua meninice. ${ }^{89}$

Assim como a lagarta tem contra si o duplo preconceito desfavorável ligado à larva - que, primitivamente, pode ser um gênio malfazejo - e ao animal rastejante de um modo geral, remetendo de certa forma à imagem da feiura, Carminha também pode ser considerada pelos aldeões como símbolo da feiura, do mau agouro.

\footnotetext{
${ }^{87}$ CHEVALIER, Jean; GHEERBRANT, Alain. Op.cit. p. 203.

${ }^{88}$ Ibidem, p. 295.

${ }^{89}$ JORGE, Lidia. O dia dos prodígios. Rio de Janeiro: Nórdica, 1984, p. 14.
} 
Por outro lado, o metamorfosear-se da lagarta, levando em consideração um dos aspectos do simbolismo da borboleta, se fundamenta nas transformações: "a crisálida é o ovo que contém a potencialidade do ser; a borboleta que sai dele é um símbolo de ressurreição. É ainda se se preferir a saída do túmulo." ${ }^{90}$ Nota-se em Carminha Parda que essa tentativa de ressurreição, de renascimento, de voltar à vida se faz presente.

Além disso, Carminha e a janela formam uma unidade; ela sempre está à janela e isso pode simbolizar uma abertura para algo melhor, uma passagem:

No mais fundo, a transparência põe estrelas e furta-cores na várzea por onde um dedão de pé agigantado parece ter desenhado um rasto e um sulco. E o barrocal de carrasco e tomilho cheiroso e cinzento, fica mais lilás na banda do mar. Esmaecido de fumo brumoso e crepitante como se a terra estremecesse sob o sol. Estrela imponderável. E a janela limpa de toda a poeira e cagadela miúda espelhasse uma cintilação suplementar. Isso na alma de Carminha. ${ }^{91}$

O romance em si parece ser de passagem (de uma condição a outra), de mudança, de metamorfose. Uma das coisas que mostram essa característica é a janela, a ponto de se notar uma personificação:

A janela tem feições de humano transfigurado em transparência, já que a quadrícula esventra dois olhos e uma testa de cantaria abaulada, nariz de batente de auto a baixo e a boca, maior do que a própria transparência só aberta quando de par em par. Então Carminha pousalhe os seios no peitoril, arredondando as costas. ${ }^{92}$

Mas, apesar dessa aparente humanização da janela enquanto abertura para o ar e para a luz (no sentido de sair de um espaço privado - quase uma clausura - para poder transitar em um espaço externo), Carminha, pelo visto, não se sentia com liberdade de ir e vir, porque "Saindo para a rua a sombra do seu pai incógnito paralisa-a, gela-lhe o arquejar [...] Uma condenação" 93 Há indícios de que ambas, mãe e filha, estejam condenadas a viver confinadas em suas casas, fora do convívio com o grupo, "dentro do seu casulo de pedra, de telha, tijolo e uma janela de vidro." 94 Ainda assim, a "janela de vidro" permanecia lá, mostra de que ainda pudesse renascer a esperança, a positividade das coisas e também de que há um jogo entre condenação e prenúncio de libertação.

\footnotetext{
${ }^{90}$ GHEERBRANT, J. \& RESNAIS, A. Dicionário de símbolos. Mitos, sonhos, costumes, gestos, formas, figuras, cores, números. 19. ed. Rio de Janeiro: José Olympio, 2005, p. 138.

${ }^{91}$ JORGE, Lídia. O dia dos prodígios. Rio de Janeiro: Nórdica, 1984, p. 12.

${ }^{92}$ Ibidem, p. 11.

${ }^{93}$ Ibidem, p. 14.

${ }^{94}$ Ibidem, p. 14.
} 
O discurso de Jesuína Palha em relação às Carmens tem um significado especial: “[...] Ah vizinhos. Estas duas aqui metidas em casa como se estivessem a chocar um ovo, e a gente a ver ali tudo." 95 Há indícios de que existe uma ambiguidade, como se elas fossem bichos, galinhas chocando um ovo. Mas esse chocar pode significar a espera por um mundo novo, o renascimento; esperando o novo acontecer.

Ao assumir-se como porta-voz da comunidade, Jesuína protagoniza a oposição entre os bons costumes da aldeia e aquilo que considera como desvio dos padrões da moral. Sendo assim, a seu modo, a porta-voz da comunidade se mostra interessada em querer zelar pela decência no vilarejo e, para isso, coloca mãe e filha à margem do grupo em razão de suas histórias pessoais.

Nessa condição, Jesuína assume, de certo modo, um papel que pode corresponder ao da figura masculina, pois se vale de uma linguagem e de gestos que, na maioria das vezes, se enquadram nos comportamentos masculinos como procedimentos geralmente esperados por homens, como "cuspir no chão" 96 , por exemplo. Além disso, em determinados momentos, Jesuína parece se apropriar de uma linguagem mais agressiva, que também pode ser uma tendência a masculinidade, quando se refere às Carmens: "a quantos tu já deste a pinguinha?" 97 e também quando faz acusações "Mas quem vem nem olha à cara. Nem sequer às pernas. Antes ao fundo delas, para se aviar depressa". 98

A única maneira, na visão de Carminha Rosa e Parda, de se livrarem dessa desonra seria esperar que viesse alguém de fora, um homem, para casar-se com a filha e levá-la para longe dali. Mas acabam percebendo que somente no interior do vilarejo, rodeadas pelos outros habitantes e em comunhão com eles, talvez conseguissem transformar o vilarejo e, consequentemente, os que ali habitavam. Em Carminha, a filha, está presente a intenção de renascimento, quando é comparada à borboleta, e de guia das almas perdidas quando comparada ao corvo. Talvez por carregar consigo essas características, mesmo sem percebê-las claramente, Carminha resolve, ao que indica, inconscientemente, construir sua vida ali mesmo em Vilamaninhos.

\footnotetext{
${ }^{95}$ JORGE, Lídia. O dia dos prodígios. Rio de Janeiro: Nórdica, 1984, p. 28.

${ }^{96}$ Ibidem, p. 145.

${ }^{97}$ Ibidem, p. 144.

${ }^{98}$ Ibidem, p 144.
} 
De acordo com Berg ${ }^{99}$, alguns paralelos podem ser traçados entre Vilamaninhos e a Carminha filha. Em primeira instância: "ambas nasceram fora da lei, sem o beneplácito da igreja e sem a aprovação do rei”. ${ }^{100}$ A ânsia pela espera também se mostra como um dado que têm em comum. Assim como Carminha Parda espera por um forasteiro que venha de longe para propor-lhe casamento, também no vilarejo as personagens (quando se comportam esperando por alguém que venha de fora para anunciar a revolução e para dar uma explicação pelo sumiço da serpente) estão à espera do surgimento de um milagre que possa proporcionar-lhes estímulo ao desenvolvimento.

Carminha Parda acaba descobrindo que a solução não viria de fora; está ali mesmo, dentro do vilarejo, na figura de Macário, o aluado cantor-jogral da vila, que sempre fora apaixonado por ela e, por isso, casa-se com ele. Ela compreende que a mudança de espaço não traria a solução para seus problemas; seria necessário que ocorresse uma transformação interna e cada habitante do vilarejo tem sua parcela de responsabilidade nesse processo.

Manuel Macário está apresentado como um homem simples que, com o seu cantar trovadoresco e seu bandolim, gostava de divertir os camponeses com sua música, proporcionando momentos de distração e apresentando sempre profunda elevação espiritual. Além de ser um artista popular, quando compõe ele próprio os seus poemas, cantando e tocando, Macário talvez possa estabelecer alguma semelhança com os galiardos, aqueles que estavam a meio caminho entre os jograis e os trovadores, compondo eles próprios, recitando e cantando. Nos poemas cantados por ele pode-se perceber que os versos fazem referência ao povo de Vilamaninhos:

Há sempre um ovo chocando.

Uma tristeza na gente $[. .$.

Como se gente pensando, pusesse um ovo no quente. [...]

Ah gente que só pensando.

Põem os ovos no quente ${ }^{101}$

Assim como Jesuína, ao se referir a Carminha Rosa e Carminha Parda comparando-nas com galinhas como se estivessem a "chocar um ovo"102 e assim como

\footnotetext{
${ }^{99}$ BERG, Eliana. O dia dos prodígios: escrita prodigiosa. Revista Colóquio Letras. Ensaio, $n^{\circ}$ 132/133, Abril, 1994, p. 147-156.

${ }^{100}$ Ibidem, p 152.

${ }^{101}$ JORGE, Lídia. O dia dos prodígios. Rio de Janeiro: Nórdica, 1984, p. 86.

${ }^{102}$ Ibidem, p. 22.
} 
na descrição de Carminha Parda o narrador faz referência às moscas "compondo um ovo de esterco redondo"103, Macário faz referência ao "ovo chocando". Nessa menção ao ovo, o cantador parece querer mostrar certa tristeza presente no vilarejo porque, pelo que se mostra, esse "chocar" parece remeter à espera, à estagnação. Pelo visto, os aldeões chocam para esperarem, talvez sem perspectiva, por algo que parecem não saber o que é.

Por outro lado, de acordo com Chevalier (2005), o ovo, "considerado como aquele que contém o germe e a partir do qual se desenvolverá a manifestação, é símbolo universal e explica-se por si mesmo."104 Para Eliade (2002) o símbolo do ovo não se refere exatamente ao nascimento, mas antes a um renascimento: "o ovo confirma e promove a ressurreição que... não é nascimento, mas um retorno, uma repetição" 105 Desses dois pontos de vista, parece ficar claro que o ovo pode ser considerado como um germe, uma realidade primordial. E essa referência ao ovo mencionada por essas personagens, ao que tudo indica, sugere uma possibilidade de renascimento na Vilamaninhos. Macário ainda diz, cantando:

Oh cobrinha do monturo. Já descem aos cagadoiros. Tem a vidinha no duto quem porqui acha tesoiros. Acha tesoiros e tesoiros ${ }^{106}$

Nesse trecho o rapaz refere-se ao desaparecimento da cobra. Ao documentar, cantando, o que se passa na aldeia, Macário mostra que há, em suas composições, traços da poesia lírica, pela maneira como expõe o seu discurso sempre ligado a um acompanhamento musical, no caso o seu bandolim. Ele também explicita que se vale da poesia não somente para expor os seus pensamentos acerca da comunidade, mas, também para expressar os seus sentimentos amorosos em relação a Carminha Parda e, diferentemente dos cancioneiros medievais, não faz questão de preservar a identidade de sua amada.

Macário não é o único representante da lírica trovadoresca que aparece no texto. Há outra figura, definida apenas como o cantador que "apareceu, vindo das bandas da

\footnotetext{
103 JORGE, Lídia. Rio de Janeiro: Nórdica, 1984, p. 11.

104 CHEVALIER, Jean; GHEERBRANT, Alain. Dicionário de símbolos: Mitos, sonhos, costumes, gestos, formas, figuras, cores, números. 19. ed. Rio de Janeiro: José Olymp.io, 2005, p. 672.

${ }_{105}$ ELIADE, Mircea. Mito e realidade. 2. ed. São Paulo: Martins Fontes, 2004.

106 JORGE, Lídia. Op. cit. p. 112.
} 
ponta extrema, nascente de Vilamaninhos" ${ }^{107}$ sendo descrito pelo narrador da seguinte maneira:

Trazia a boca muito aberta de cantar, e os olhos fechados como se fosse cego, tendo o dom de se desviar dos valados e das esquinas, apenas pelo faro, Balançava o bandolim de peito a peito e a mão tremia, fechada em punho sobre a boca da caixa. Como se lhe vibrasse uma verdadeira língua. Vinha sem abrigo nem chapéu, e as botas por atar. Vinha cantando. Apenas as palavras eram tão prolongadas que perdiam o corpo, e alguns sons tão represos na garganta que pareciam sussurros. Cantando ${ }^{108}$

Aluado durante metade de cada mês e apaixonado pela jovem Carminha Parda, Macário sofre por concorrer com estranhos ao amor de Parda, mas, quando finalmente a conquista, está pronto para defendê-la em público, prova de que a condição de figura masculina dominadora parece não fazer parte da sua personalidade. O jovem parece representar uma presença da elevação espiritual e estética da Idade Média.

Ao que parece, a união de Carminha Parda e Macário talvez possa contribuir para iniciar um possível desenvolvimento do vilarejo, já que Carminha Parda, diferentemente dos outros que ali habitam, parece possuir um grau de consciência um pouco mais elevado. É possível comparar o nível de consciência de Carminha a filha em relação à Jesuína Palha, por exemplo, pois a segunda parece ter os pés enraizados no vilarejo (lugar que "parece um ovo emurchecido, que não vinga") e, consequentemente um nível mais primitivo de consciência em relação à primeira.

Provavelmente, a precariedade no que se refere ao grau de consciência dos habitantes se instala em razão de que a relação "eu" e "outro" parece não se aplicar no interior do vilarejo, nem tampouco em relação ao que ocorre fora dali. O processo de formação da consciência, para Bakhtin 109

concebe a outridade como o fundamento de toda a existência e o diálogo como a estrutura primacial de qualquer existência particular, representando uma constante troca entre o que já é e o que não é ainda. O registro e o plasmador dessas transformações é a consciência humana, que modula o intercâmbio contínuo entre as atividades "eu" e tudo o que é "não-eu-em-mim". ${ }^{110}$

Quando se trata de Vilamaninhos, o diálogo parece não se estabelecer e quando falam todos ao mesmo tempo o fazem propositadamente, "para que ficasse bem claro o

\footnotetext{
${ }^{107}$ JORGE, Lídia. O dia dos prodígios. Rio de Janeiro: Nórdica, 1984, p. 94.

${ }^{108}$ Ibidem, p. 94.

${ }^{109}$ CLARK, Katerine; HOLQUIST, Michael. Mikhail Bakhtin. São Paulo: Perspectiva, 1998.

${ }^{110}$ Ibidem, p. 91.
} 
desentendimento" 111 O fato de grande parte das personagens que lá habitam serem semianalfabetas e com pouca instrução pode contribuir para a não interação e para o não desenvolvimento da consciência. Vale ressaltar que, no interior da aldeia, as aparentes trocas conversacionais que ocorrem entre os aldeões não parecem favoráveis ao processo de formação da consciência, porque a falta de contato com aquilo que está fora da vila não somente ocasiona um isolamento, mas também podem condenar os aldeões à marginalização e ao desterro.

Há indícios de que isso talvez propicie a não formação de uma identidade. No que se refere à identidade pessoal, esta pode ser desenvolvida num processo relacional (pessoas com as quais se cultiva trato de cortesia ou de amizade), que envolve a distinção entre uma identidade para si e para outrem. Esse processo relacional, ao que parece, não se processa em $O$ Dia dos Prodígios, pois as personagens não se relacionam entre si, nem com outros que vivem fora do vilarejo: isso pode ocasionar o não reconhecimento talvez pelo contexto em que essas personagens estão inseridas, de repressão, de sofrimento, de exclusão. Isso ocorre na narrativa especialmente com as personagens femininas porque sofrem em razão de maus tratos que lhes são infligidos (pela sociedade, no caso de Carminha Rosa e Carminha Palha; ou pela figura masculina, a exemplo da personagem Branca Volante).

No núcleo das personagens com um nível de consciência um pouco mais elevado apresenta-se Branca Volante, que vive em matrimônio com Pássaro Volante. A dedicação de Branca aos filhos, ao marido e aos trabalhos relativos a esse papel como representante do lar preenche a totalidade de suas horas livres. Branca acaba obedecendo, por imposição do marido, às regras que lhe são fixadas e desenvolve, aparentemente com primor, os papéis de esposa e mãe. Pássaro Volante impunha a sua autoridade e não permitia que ela afastasse os seus pensamentos dos afazeres do lar, e ela obedecia

porque se alguma coisa faltasse fazer, e as escamas do dragão crescessem. Ah dedinhos, Branca estaria a esquecer-se dos seus deveres, e forçoso seria fazê-la lembrar. Cinco dedos estampados na pele. Não era para doer. Era mais a marca e lembrança ${ }^{112}$

Além de ser submetida ao poder masculino e desrespeitada em seus direitos de ser humano e livre, Branca ainda era associada a uma "mula", pois ambas, mula e

\footnotetext{
111 JORGE, Lídia. O dia dos prodígios. Rio de Janeiro: Nórdica, 1984, p. 9.

${ }^{112}$ Ibidem, p. 36.
} 
mulher, são insolentes, loucas e também, perversamente, misteriosas e cínicas. No princípio, Branca não passa de uma substituta da mula do marido; até a descrição de ambas se assemelha: "Branca vista de frente parece uma lagarta, porque "Os olhos fecharam-se de vermelho e inchaço de lágrima. Mas de lado parece uma erva de folha fina" ${ }^{113}$ [...] Contudo, vista de frente e de lado, a mula era "redonda e manteúda, o pêlo ruivo e brilhante". ${ }^{114}$ Novamente vê-se a descrição de uma personagem em relação a animais, desta vez a uma mula.

Como se não bastasse, o ato sexual entre Pássaro e Branca também é descrito como se ela fosse realmente uma mula:

Pássaro cavalga. Branca é um dorso macio de aragem pelada. Pássaro cavalga como se a montada tivesse partido à desfilada pelos caminhos, e ele cego por ver a terra tremer. E então o estremecimento sobre a montada da cama, veloz e horizontal, como se Pássaro se quisesse sacudir de si próprio, despejar o seu interior ai sobre ${ }^{115}$.

Pelo que se pode notar, Pássaro usa sua esposa para "se libertar das forças inúteis do seu corpo" ${ }^{116}$; não só a considera como um objeto, mas também parece querer privá-la de sua própria sexualidade.

Branca não era submetida somente aos abusos que seu marido lhe infligia, mas também era subtraída de seu próprio corpo, de sua própria voz: "E eu mais do que submissa, acobardada. Caladinha" ${ }^{117}$. Diante dessas circunstâncias, Branca parece não ter alternativa, restando-lhe continuar submissa e manter-se numa condição servil. $\mathrm{Na}$ visão de Pássaro, para que isso se perpetuasse, Branca teria que ocupar todo e qualquer tempo que lhe restasse livre: por isso Pássaro impôs-lhe o bordado. Desse modo, "Branca Volante passaria as tardes com o espírito além das parreiras"118, sem ter tempo de afastar os seus pensamentos dos afazeres do lar. Mesmo assim, Pássaro temia o que se passava no espírito, pois era certo que isto ele "nunca poderia medir nem calcular" 119 .

Branca limita-se a sofrer o mau tratamento que recebe do marido, mas o faz enquanto borda um dragão no centro de uma colcha de linho cru, à semelhança de Penélope na longa espera do marido Ulisses, que tinha ido guerrear em Troia. No mito,

\footnotetext{
${ }^{113}$ JORGE, Lídia. O dia dos prodígios. Rio de Janeiro: Nórdica, 1984, p. 36.

${ }^{114}$ Ibidem, p. 39.

${ }^{115}$ Ibidem, p. 48.

${ }^{116}$ Ibidem, p. 128.

${ }^{117}$ Ibidem, p. 35

${ }^{118}$ Ibidem, p. 35 .

${ }^{119}$ Ibidem, p. 35.
} 
Penélope era apaixonada por Ulisses e, para não ter que casar-se com outro, lança mão de um artifício, o bordado, para ganhar tempo, ainda esperançosa do regresso de Ulisses. Penélope alegou que estava empenhada em tecer uma tela comprometendo-se em fazer sua escolha entre os pretendentes que já estavam a postos quando a obra estivesse pronta. Para Penélope o bordado era uma escolha; já para Branca uma imposição.

Durante o dia, aos olhos de todos, Penélope trabalhava tecendo; à noite, secretamente desfazia o trabalho feito. E a famosa "Tela de Penélope" passou a ser uma expressão proverbial, para designar qualquer coisa que está sempre sendo feita, mas que nunca termina. Sua façanha não durou muito tempo e, sendo descoberta, Penélope teve que escolher entre os pretendentes. Apenas um camponês humilde conseguiu realizar a proeza de encordoar o arco de Ulisses. Imediatamente este camponês revelou ser Ulisses, disfarçado após seu retorno e os dois permaneceram em união.

No caso de Branca, ela não desfaz os fios. Ao que parece, o bordado de Branca vai tomando proporções que não remetem somente à espera, mas a uma possível libertação. Branca, assim como Penélope, não parece desejar continuar na companhia do marido, pelo menos naquelas condições de maus tratos. Isso começa a se evidenciar na narrativa quando Branca começa a mudar seu comportamento.

$\mathrm{O}$ ato de bordar resgata em Branca um dom que tinha desde menina e isso a faz “ir mais além do presente até agarrar o futuro, com uma vidência feita de sobressaltos e chamada por palavras". ${ }^{120}$ Com esse dom, ela recebe, então, a notícia da fuga da mula como um sinal de que sua vida mudaria. A partir de então, a mulher que talvez pudesse representar no vilarejo a submissão feminina começa a dormir de olhos abertos e começa a ver através das pessoas, "ver a transparência como através de um vidro." 121 Os poderes de Branca começam a tomar proporções cada vez maiores, e essa aparente passividade vai-se transformando. No isolamento da casa e na aparente prisão do bordado, vai nascendo o sonho que leva Branca a afirmar a sua personalidade em confronto com o marido, isto é, na medida em que o bordado evolui, parece que a aldeã vai tomando consciência de si.

O dom que Branca possuía não era recente, pois, desde que tinha dezessete anos, embora Pássaro dissesse a sua mulher que esta virtude era uma falsa fantasia, Branca identifica "quem vai chegando às portas da vizinhança mesmo sem os cães ladrarem. E,

\footnotetext{
${ }^{120}$ JORGE, Lídia. O dia dos prodígios. Rio de Janeiro: Nórdica, 1984, p. 60.

${ }^{121}$ Ibidem, p. 46.
} 
se ladram, eu ouço o regougar da garganta ainda antes de se ouvir o ladrido."122. Pelo que se observa, Branca é capaz de prever os acontecimentos da vida. Com isso, ela mergulha em uma dimensão temporal: "pouco a pouco deixou de haver presente" ${ }^{123}$, e a personagem passou a sentir-se "num ponto movediço de viscosidade" ${ }^{124}$. Isso mostra que o próprio gesto de tecer e fiar pode significar, para Branca, o entremear ou entrelaçar da realidade com a irrealidade.

Pássaro passou muito tempo sem acreditar no que Branca dizia, chamando-a de enteada do diabo e acusando-a de estar disposta a enlouquecê-lo. Certo dia, ela provou que era capaz de saber tanto de coisas do passado, falando do paradeiro de um canivete que Pássaro havia perdido quando tinha dez anos ("Vai junto do poial dos cântaros, levanta o terceiro ladrilho a contar da direita e lá o encontrarás" ${ }^{125}$ ) e também prevendo coisas futuras: "aqui à nossa porta, gente dos quatro ventos de Portugal virá fazer bicha de várias voltas. E ainda que tu não marques um preço, as esmolas vão ser tantas que terás para comer durante toda a vida" ${ }^{126}$. Todas as evidências apontam para a existência do dom de Branca e, por meio de suas visões, era capaz de prever o futuro até das pessoas.

Nesse ínterim, aparece um cantoneiro que se apaixona por Branca e a convida para ir embora do vilarejo com ele. O forasteiro acreditava que a possibilidade de melhora, no que se refere ao convívio com o que estava externo ao vilarejo e a uma possível conscientização de si, não seria possível no interior do vilarejo. Na realidade, o início da formação desse processo, de acordo com as palavras do cantoneiro (personagem que parece ter consciência de que o "prodígio" está dentro de cada um), só depende de cada indivíduo estar disposto a reconhecer a si mesmo. E o cantoneiro disse:

Às vezes costumo dizer. Amo as palavras bonitas, mas quando ouço certas coisas, ah punhão, apetece-me ir buscá-las ao fundo das tripas e do buraco que se chama recto. Ninguém. Ninguém se liberta de nada se não quiser libertar-se. E ainda disse: Mas aqui. Aqui ficam todos pelo desejo das coisas. ${ }^{127}$

\footnotetext{
122 JORGE, Lídia. O dia dos prodígios. Rio de Janeiro: Nórdica, 1984, p. 64.

${ }^{123}$ Ibidem, p. 166.

${ }^{124}$ Ibidem, p. 166.

${ }^{125}$ Ibidem, p. 167.

${ }^{126}$ Ibidem, p. 68.

${ }^{127}$ Ibidem, p. 170.
} 
A fala do forasteiro revela certa consciência de que a mudança precisa ser interna, mas, ainda assim, ele resolve ir embora do vilarejo em razão de perceber a impossibilidade de realização do seu amor por Branca Volante.

Branca não se encorajou a acompanhar o forasteiro, porque, mesmo amando as palavras bonitas, "às vezes apetece-me ir buscá-las no fundo das tripas e das fezes. Ninguém se liberta se não quiser libertar-se." ${ }^{128}$ Pelo que se nota, ela acredita que o "prodígio" está dentro de cada um e, por isso, decide permanecer na vila.

Entre as personagens femininas apresentadas no romance, Branca aparenta ser, em primeira instância, aquela que mais se submete aos demandos do marido, Pássaro Volante, e que possivelmente apresenta maior dificuldade em partir rumo à construção do reconhecimento de si mesma. Mas as ações dessa personagem acabam convergindo para uma transformação. Isso ocorre porque, além de recuperar seu dom de vidência, se rebela contra o marido, que lhe infligia maus tratos, dando nele uma surra.

Interessante observar que o dragão bordado na colcha também remete não somente a uma aparente libertação da personagem, como também faz alusão à história de Santa Margarida. Trata-se de uma jovem que, desde a infância, apresentava afinidades com o catolicismo, mas seu pai (adepto do paganismo) não admitia que a filha seguisse os preceitos de uma religião que ele não aprovasse. Dentre os castigos que infligiu à filha, o cárcere privado foi um deles. No cárcere em que Margarida se encontrava, como diz a lenda, teria sido supostamente visitada por Satanás, que aparece em forma de um dragão e acaba engolindo-a. Mas Margarida consegue sair do ventre do dragão mostrando um grande crucifixo que levava nas mãos.

Assim como Santa Margarida, Branca parece domesticar o dragão. A santa vence o poder dominador do pai, enquanto Branca parece ter se desvencilhado do poder dominador do marido. Parece possível considerar, na narrativa de Lídia Jorge, Pássaro Volante como a representação do próprio dragão. Quando Pássaro agia como se Branca fosse sua propriedade (escravizando-a e maltratando-a), ele acreditava que tinha total domínio sobre a esposa. À medida que Branca desenvolve o bordado (o dragão alado com asas cintilantes), Pássaro perde o controle sobre Branca. A narrativa dá pistas de que o dragão representa, para a esposa de Pássaro Volante, a libertação. O libertar-se do ventre no dragão mencionado na história de Santa Margarida pode remeter (no caso de Branca) à libertação da submissão à qual era submetida pelas imposições do marido.

${ }^{128}$ JORGE, Lídia. O dia dos prodígios. Rio de Janeiro: Nórdica, 1984, p. 105. 
Outro fato que parece contribuir para o despertar da consciência de Branca ocorre no final do romance, quando a personagem encontra-se com o forasteiro e ele a convida para ir embora dali. A personagem tem a oportunidade de contato com o que está externo ao vilarejo, mas recusa a possibilidade de saída.

Ao que parece, Branca se mostra como a única personagem no vilarejo que possui um germe de formação de identidade. Acredita-se que o fato de ter-se libertado do marido e recuperado seu dom adormecido não remete ainda à presença de uma identidade. Trata-se, porém, do início de um processo muito longo a ser percorrido e, pelo que se nota, Branca está em busca de uma identidade individual (quando se concentra em seus próprios interesses) e, ao mesmo tempo, inserida no coletivo (considerando que a busca dessa identidade pode ser também feminina, ou seja, de um grupo específico, o das mulheres).

Branca parece buscar a continuidade de si mesma, uma identidade que não se restringe a sua pessoa, mas a um grupo feminino. Se Branca não tivesse recuperado seu dom de vidência e enfrentado o marido, seria difícil dar início à construção do sujeito mulher, melhor dizendo, muito provavelmente não seria possível a construção desse sujeito na sua individualidade e coletividade. Atrelada à questão da construção do sujeito está o reconhecer a si mesmo e ser reconhecido. Branca, pela maneira como conduz suas ações, parece almejar esse reconhecimento de si e também ser reconhecida: acredita-se que, primeiramente, pelo marido, pois, somente assim, o processo de construção de sua identidade teria início.

Vale lembrar que se trata de um processo embrionário da formação de consciência, mas, comparado ao estágio primeiro em que Branca se encontrava, pode ser considerado um avanço, uma tomada de consciência que fez Pássaro Volante perceber que sua esposa estava agora diferente: “Agora esse pressentimento de que mesmo inchada de socos e pedindo perdões com a língua, sempre ela havia de estar acima de si” ${ }^{129}$ porque “... tudo o que eu lhe disser já ela antes saberá e assim estará sempre adiante de mim, e eu atrás, atrás [...] sem conseguir ultrapassá-la". ${ }^{130}$

Branca deixa transparecer que, naquele momento, inicia o reconhecimento de si mesma por intermédio da atividade e da consciência. Por outras palavras, Branca começa a reagir de acordo com o contexto social e, nesse romance, tem-se a referência de um contexto de repressão por causa do momento de opressão que se vivia na ditadura

\footnotetext{
${ }^{129}$ JORGE, Lídia. O dia dos prodígios. Rio de Janeiro: Nórdica, 1984, p. 148-149.

${ }^{130}$ Ibidem, p. 149.
} 
salazarista. Desse modo, as identidades das personagens parecem estruturadas de modo que atendem àquele contexto, que as quer submissas e alienadas. Mas Branca, com seus poderes intuitivos, pretende mudar esse cenário e, com a sabedoria que nasce dentro de si, acaba renunciando ao amor do cantoneiro e decide permanecer em Vilamaninhos para solidificar a mudança e trazer o bem que, talvez, a partir dela, possa chegar àquela terra.

Com as outras personagens femininas, exceto as Carminhas Rosa e Parda, essa oportunidade não surge porque o espaço do vilarejo contribui para a estagnação, e o fato de não saírem dali as faz permanecer naquele estado de mesmice, ocasionando o não contato com o outro e, consequentemente, a não conscientização de si mesmas.

Pelas pistas que a narrativa oferece, o princípio da conscientização de reconhecimento de si parece estar principalmente em Branca Volante e em Carminha Parda. Em uma escala menor, há indícios que isso se desenvolva também em Carminha Rosa e Macário, como é perceptível pelas ações dessas personagens, que remetem, mesmo que embrionariamente, ao início da busca de um caminho a ser percorrido rumo à superação desse estádio de estagnação e mesmice que parece envolver a todos do vilarejo.

Para Carminha, primeiramente, pelo fato de impor à mãe sua vontade, ou seja, por decidir não esperar mais por um pretendente que venha de fora, encontra a solução para seu caso amoroso dentro de Vilamaninhos, casando-se com Macário. O drama de Carminha Parda, inclusive, está indiretamente associado ao mito de Édipo, de quem ela já ouvira falar:

Carminha tinha ouvido falar de um homem do princípio do mundo, desenterrando os olhos com os próprios dedos, [...] Coberto de sangue, a andar de porta em porta pedindo pão pelo amor de deus. E isso tudo não por culpas presentes, mas tão passadas que já nem eram suas. Um severo animal quase mudo, dizendo charadas a quem entrasse na cidade. ${ }^{131}$

Pelas palavras de Carminha Parda, nota-se a presença do mito, aparentemente enraizado no cotidiano de Vilamaninhos. Pelo que parece, mesmo que não tendo muito conhecimento dos fatos, Carminha, em alguma ocasião, já ouviu falar a respeito do mito e imediatamente faz relação entre ele e a sua própria história. Essa relação, pelo que parece, é feita inconscientemente, mas o fato é que a presença dele se mostra marcante na aldeia, e ela percebe que está sendo castigada injustamente e por isso quer ser aceita

${ }^{131}$ JORGE, Lídia. O dia dos prodígios. Rio de Janeiro: Nórdica, 1984, p. 38. 
naquela comunidade, independentemente de ser filha de um padre. Porém, ela ainda permanece "Coberta de sangue, a andar de porta em porta pedindo pão pelo amor de deus." ${ }^{132}$, ou seja, continua sendo julgada e excluída por todos da comunidade em razão de seu pai incógnito, mesmo afirmando que "isso tudo não foi por culpas presentes, mas tão passadas que já nem eram suas."133

No mito de Édipo, este era filho de Laio e de Jocasta. Por causa da prioridade em um desfiladeiro estreito, Édipo mata Laio, ignorando que este era seu pai. A caminho de Tebas encontra a Esfinge, um monstro, meio leão, meio mulher, que devorava aqueles que não conseguiam responder aos seus enigmas. Ao decifrar o enigma desse monstro que devastava a região, Édipo o mata e, por isso, é aclamado rei. Como recompensa, recebe Jocasta, viúva de Laio, como esposa, sem saber que ela é sua própria mãe. Quando descobre esse fato, Édipo, arranca seus próprios olhos e Jocasta se mata.

O mito de Édipo, segundo algumas interpretações, se apresenta como símbolo do homem que oscila entre o nervosismo e a banalização. Ele compensa sua inferioridade (a alma ferida) por meio da ativa busca de uma superioridade dominadora. Desse modo, a presença do mito na narrativa pode simbolizar o sentimento de inferioridade que a personagem Carminha, a filha, possui em relação aos outros habitantes do vilarejo, por ser filha de um pai incógnito.

Por outro lado, o mito também pode estar relacionado à culpa que os habitantes do vilarejo impõem à Carminha Parda. Até certo ponto, ela assume essa culpa, mas finalmente acaba se libertando no momento em que decide não se casar com o Sargento Marinho (outro pretendente de Caminha a filha que, com orgulho, contava aos aldeões seus feitos heroicos na guerra, mas se mostrou muito cruel quando espancou os cães em praça pública). Neste caso, o que ocorre com Carminha é o inverso do que ocorre no mito: enquanto Édipo arranca seus olhos para não ver a verdade, a capacidade de visão (interior) da personagem Carminha parece surgir quando se liberta de sua culpa. Carminha assume, por assim dizer, sua própria verdade: a de que não quer submeter-se à tirania do grupo.

O gesto de limpar a janela, os movimentos que Carminha faz em círculos parecem remeter, de certa forma, a um anseio de libertação. Quando limpava aquelas janelas com afinco, dando atenção às minúcias, Carminha "empertigava-se de encontro

\footnotetext{
${ }_{132}$ JORGE, Lídia. O dia dos prodígios. Rio de Janeiro: Nórdica, 1984, p. 38.

${ }^{133}$ Ibidem, p. 38 .
} 
à mancha renitente entre a unha e o vidro. Minúscula...". ${ }^{134}$ Nesse gesto parece que há um desejo que vai além de remover as sujeiras e os refugos das asas das moscas. Carminha parece querer limpar de si tudo aquilo que, aos olhos dos aldeões, denota suas impurezas. Pelo que parece, tudo se processa por conta da filiação da moça. O fato de Carminha ser filha de um padre, sob o ponto de vista do povo do vilarejo, pode ser prejudicial para a preservação da mentalidade religiosidade na vila. As evidências levam a crer que a ausência de um padre no vilarejo ocorre por conta do nascimento de Carminha. Sendo assim, possivelmente se sinta culpada por ter que carregar consigo esse estigma e, por isso, por meio da limpeza da janela, é possível que tente limpar de si essas "impurezas".

A tentativa de limpar, de retirar aquilo que é prejudicial, pode convergir, no caso de Carminha, para o tornar-se limpa, removendo de si todo o conteúdo que pode obstruir a alma e, de certa forma, impedir o reconhecimento de si mesma. Esse gesto, pelo que se nota, pode dar início à busca de uma identidade. Neste sentido, é provável que, para Carminha, o limpar tenha essa conotação.

Para Branca, a opressão parece ser superada quando, com sua privilegiada vidência, se liberta da sujeição ao marido e, como ela mesma diz, "eu própria fiz mudança, porque nunca consegui dizer tantas palavras junto de ti. Ou seja, da noite, ou da revolução, ou de mim mesma". ${ }^{135}$ Ao que parece, esta personagem liberta-se da tirania do marido, e ele, indiretamente, contribui para isso, pois, quando ordenou a ela o bordado, com o intuito de prender os pensamentos de Branca exclusivamente aos assuntos domésticos, na realidade a liberava para seu espaço de liberdade interior.

O gesto de bordar (o criar com as próprias mãos) pode remeter ao gesto ancestral da própria criação do mundo e à previsão do futuro (o criar com o próprio espírito). Desse modo, pode-se dizer que há uma aliança entre o bordar e o prever o futuro, a qual pode caracterizar, nesta personagem, a libertação, o princípio da busca de uma conscientização rumo à construção da identidade feminina. Ao longo da narrativa, dos que habitavam a vila, Branca era, talvez, a única que criava algo com suas próprias mãos, ou seja, a única que tinha plantado a semente da esperança e que tinha a visão de um futuro, mesmo que fosse o dos outros.

Se este ato de Branca simboliza sua elevação espiritual, a evolução do seu nível de consciência, em Carminha Parda o ato que simboliza processo semelhante é o de

\footnotetext{
${ }^{134}$ JORGE, Lídia. O dia dos prodígios. Rio de Janeiro: Nórdica, 1984, p. 11.

${ }^{135}$ Ibidem, p. 148.
} 
limpar as janelas. No romance, ambas as ações, o bordar e o limpar, se caracterizam por serem vagarosas e atentas, um convite à introspecção e ao caminho para o autoconhecimento. Essas duas atividades remetem à ideia de que podem ser consideradas mais comumente como trabalhos manuais típicos do universo feminino. Especificamente sobre o bordado, pode-se dizer que se considera uma atividade capaz de despertar paixões e motivar comportamentos individuais. Em determinados casos, como no de Branca, comportamentos que estavam adormecidos (o dom da vidência, por exemplo).

O tecer e o limpar, da maneira como são apresentados na narrativa, parecem caminhar juntos e podem remeter a uma atividade do espírito, dos sentidos que, para Branca e Carminha, se desenvolvem essencialmente pela intuição, faculdade que ambas parecem desenvolver por meio da percepção (no caso das duas personagens: ao desenvolverem o ofício de tecer e limpar mudanças em seus comportamentos começaram a ocorrer). Elas desenvolvem um processo de discernir ou pressentir coisas, independentemente de raciocínio ou análise. Isso mostra que as transformações no comportamento das personagens ocorrem involuntariamente.

Além disso, envolvem, ainda, uma ligação com o ato de "ver" para além da realidade imediata, uma vez que, para Branca, o dragão que ela borda parece querer saltar do tecido e ganhar vida própria, tanto que, para Branca:

Permanecia de qualquer forma a impressão de que não estava só. $\mathrm{O}$ animal bordado por si rabiava lá dentro. E ela dizia que fechava os olhos e tapava os ouvidos, e continuava e não estar sozinha. Oh deus. Se o tiro e o deixo numa cadeira, parece que o bicho e toda a colcha me vão no encalço dos pés, atrás, atrás de mim. Se o estendo debaixo dos colchões é como se de noite eu sentisse o seu vulto arquear as costas, e ouço o rasmalhar das asas a querer afofar-se debaixo do peso do meu corpo. ${ }^{136} 7$

Para Carminha, a limpeza liga-se à condição de ver para além do seu espaço de enclausuramento, podendo, talvez libertá-la da condição que vivia.

Quanto à personagem Macário, mesmo se enquadrando no rol das personagens masculinas, ele parece ter um comportamento diferenciado em relação aos homens do vilarejo. Primeiramente, porque se mostra como um ser que tem o dom da poesia, aquele que tem imaginação inspirada (por isso exprime os acontecimentos do vilarejo cantando) e, também, como aquele que é dado a devaneios. "Manuel Macário acordou

${ }^{136}$ JORGE, Lídia. O dia dos prodígios. Rio de Janeiro: Nórdica, 1984, p 151. 
de insolação lunar, e tendo tido conhecimento detalhado de tudo o que se passara nem matou a fome de catorze dias, três horas e trinta minutos" ${ }^{137}$. É o que ocorre com a personagem em questão, enquanto dorme é como se desaparecesse, morresse. Mas, após um tempo, reaparece e, nesta aparição, Macário se comporta como se tivesse passado por um período de transformação.

Pode-se notar que a causa da insolação é atribuída à Lua, que, segundo Chevalier e Gheerbrant, simboliza os ritmos biológicos, pois é um

astro que cresce, decresce e desaparece, cuja vida depende da lei universal do vir-a-ser, do nascimento e da morte... a lua conhece uma história patética, semelhante à do homem... mas sua morte nunca é definitiva... ${ }^{138}$

Do mesmo modo que ocorre com a Lua, Macário acorda com suas forças renovadas e, como se nada tivesse acontecido,

Afinou o bandolim com o ouvido sobre a madeira e o dedo zerpando as cordas, palheta dá-lhe que dá-lhe até achar oportuno, E não guardou o riso para o dia seguinte. Achava ele que vindo de outras esferas. Ah sem dúvida. Podia sorrir do que acontecia aos mortais que comiam e defecavam os trinta dias do mês. ${ }^{139}$

Pelo que se percebe, Macário se mostra com características que o diferenciam das outras personagens. $\mathrm{O}$ fato de compor seus próprios poemas mostra que Macário possa ter uma visão regida pela emoção. Expõe a seu modo, por meio de sua poesia, seu estado alma, seus sentimentos e emoções mais subjetivas, e isso, principalmente naquele contexto em que os homens devem expor a sua masculinidade, é pouco comum. Essas características podem ser consideradas como próprias de um poeta, e Macário se mostra como tal.

O fato de casar-se com Carminha e de ser dotado dessa sensibilidade que é peculiar aos poetas talvez possa contribuir para que, juntos, possam iniciar alguma mudança no vilarejo e no processo de desenvolvimento da consciência.

Existe, ao que parece, um embrião de formação de identidade feminina nessas personagens, mas, por outro lado, há alguns fatores que podem contribuir para o não desenvolvimento dessa identidade, e isso pode ser observado por meio das relações que essas mulheres estabelecem com o masculino. Pássaro Volante, companheiro de Branca

\footnotetext{
${ }^{137}$ JORGE, Lídia. Rio de Janeiro: Nórdica, 1984, p. 38.

${ }^{138}$ CHEVALIER, Jean; GHEERBRANT, Alain. Dicionário de símbolos. Mitos, sonhos, costumes, gestos, formas, figuras, cores, números. 19. ed. Rio de Janeiro: José Olymp.io, 2005, p.561.

${ }^{139}$ JORGE, Lídia. Op. cit. p. 38.
} 
Volante, se mostra como veículo da opressão feminina. Estabelece com a mulher uma relação conjugal autoritária, escravizando-a dentro de sua própria casa, impingindo-lhe maus tratos (espancando-a e violentando-a), tentando fechá-la no circulo do bordado.

Mas talvez outro tipo de comportamento da figura masculina em relação à mulher não fosse de se esperar, exatamente por estarem situadas as personagens em meio ao regime ditatorial português (que se inicia em 1926 e perdura até 1974, marcado pela inspiração no modelo político de Mussolini e governado pelo ministro da fazenda Antonio de Oliveira Salazar). Os três pilares valorativos do governo de Salazar são a Igreja, a Pátria e a Família e, na esteira dos valores familiares tradicionais, esse status quo promove a subalternidade da mulher em face do homem, considerado o chefe da família e aquele que tem total controle. Inserido nesse cenário, o comportamento de Pássaro Volante não poderia ser diferente, porque a estrutura dominante daquela época era patriarcal e ele, muito facilmente, adequou-se a esse contexto.

Mesmo quando se trata de Branca Volante e Carminha Parda, figuras que, pelo que foi mostrado, podem remeter a maior proximidade no que se refere à iniciação do processo de reconhecimento de si mesmas, a identidade feminina ainda se configura apenas como um embrião, porque o espaço e o tempo presentes na narrativa convergem para a estaticidade.

No que se refere ao espaço, a constituição geográfica de Vilamaninhos ${ }^{140}$, como já foi dito, apresenta um vilarejo em que grande parte das mulheres está condicionada aos trabalhos domésticos: executam trabalhos fora de casa, no campo e também cuidam do lar, dos filhos, do homem. As relações que se estabelecem ali restringem-se aos limites daquele espaço, e trata-se de um lugar, assim como Lídia Jorge o descreve, em forma de estrela, fechado em si. Esse local, que pode remeter à estagnação, serve como empecilho para a constituição da consciência das personagens, primeiramente porque não conseguem ultrapassar as barreiras impostas por esse espaço, que causa uma espécie de aprisionamento, e depois porque ficam ali - paralisadas, sem possibilidade de interação com outros que estão fora dali.

Além disso, a Revolução dos Cravos, que está acontecendo em Lisboa naquele momento, não alcança os espaços que estão periféricos em relação a esse centro de ação

\footnotetext{
${ }^{140}$ Vale considerar que o nome atribuído ao vilarejo, Vilamaninhos, já sugere falta de desenvolvimento, pois o "maninho" é considerado como aquele que não cultiva, estéril, infecundo. Portanto, a possibilidade de progressão no que se refere à ascensão intelectual e cultural por meio das relações com o outro é praticamente nula ali. Este pode ser considerado um dos motivos que contribui para a não formação de uma consciência, que só se compõe na coletividade, ou seja, numa relação com o outro, o que não ocorre.
} 
político-social. Evidentemente, as pessoas que residiam em vilarejos não habitavam o grande centro de Portugal, Lisboa, e estavam afastadas de todo e qualquer acesso à informação e, por esse motivo, não conseguiam dar à Revolução a atenção e o significado merecidos. Porém, as atitudes das personagens evidenciam que a consciência que elas têm de sua condição sócio-histórica é quase nenhuma, pois não conseguem perceber a importância da Revolução de 74 para a sociedade portuguesa, uma vez que, como se disse, não há uma relação dialógica com o que está externo ao povoado.

$\mathrm{Na}$ ausência dessa relação, o processo de construção de identidade não se desenvolve. De acordo com Castells, a identidade remete ao "processo de contrução de significado com base em um atributo cultural, ou ainda, um conjunto de atributos culturais interrelacionados, os quais devem prevalecer sobre outra forma de significado". ${ }^{141}$ No espaço limitado de Vilamaninhos, fechado, arcaico, as relações sociais não são construídas e, consequentemente, por não terem os habitantes acesso à cultura, acabam se isolando no interior das relações restritas ao vilarejo.

O espaço, que se apresenta de forma delimitada, fechada, favorecendo o desenvolvimento de uma mentalidade arcaica por parte das personagens também se mostra pouco favorável para a construção de uma identidade. Não somente por esses dois fatores, mas ainda pelo próprio comportamento das personagens, voltado somente para os próprios interesses, com uma mentalidade semianalfabeta, mostrando-se incapazes de estabelecer relação entre eles e também com o que está externo ao vilarejo. De fato, percebe-se que Vilamaninhos pode representar um "ovo emurchecido".

Apesar dessa mentalidade rústica, atrasada e da espera de transformações que tanto tardam, nota-se que há presença de um sentimento de quem vê uma possível realização de algo, e isso se evidencia por meio de Branca Volante e Carminha Parda, como já foi mencionado anteriormente. Lídia Jorge mostra que a atitude dessas personagens talvez possa iniciar um semear da consciência de si. Isso é apresentado ainda de uma maneira que remete ao estágio inicial de desenvolvimento, numa condição que se mostra tão elementar a ponto de parecer se apresentar no estágio antes de deixar a condição de ovo.

Essa transição, ou seja, esse processo iniciático, ocorre muito lentamente e isso também está presente no segundo romance da autora, $O$ cais das merendas. Neste

141 CASTELLS, Manuel. O poder da identidade. A era da informação: economia, sociedade e cultura. São Paulo: Paz e Terra, v. 2, 1999, p. 22. 
romance o contexto se apresenta com algumas diferenças porque se tem a presença do estrangeiro e também uma mudança de espaço, com a interferência de alguns elementos da globalização. A mentalidade das personagens ainda se apresenta com algumas semelhanças em relação às personagens de $O$ dia dos prodígios, e o importante é que tanto no romance em questão quanto no segundo ainda parece haver um fio de esperança, e isso impulsiona o ser humano, de uma forma ou de outra, ao desenvolvimento. 
CAPÍTULO II

A BUSCA DA IDENTIDADE PERDIDA EM $O$ CAIS DAS MERENDAS 
Ao fazer a leitura d' $O$ cais das merendas, segundo romance de Lídia Jorge, o leitor pode adentrar, num primeiro momento, um espaço denominado Redonda (um sítio caracterizado como um espaço rural). Entre esse espaço e o de Vilamaninhos, de $O$ dia dos Prodígios, é possível estabelecer alguma semelhança, já que, em ambos, se trata de um ambiente rural, onde aparentemente nada se transforma e tudo converge para uma mesmice que não permite a evolução daqueles habitantes (no sentido de não haver contato com o externo à vila). Mas há também diferenças. Vilamaninhos, por exemplo, não se transforma, mantém as mesmas características estagnadas, pelo fato de seus habitantes não terem condições (talvez pela falta de conhecimento de si mesmos) de mudarem seus comportamento, nem, o que é mais importante, de permitirem o adentramento do que vêm de fora. Já em $O$ cais das merendas, as personagens manifestam uma intenção de mudança.

No contexto desse segundo romance, há indícios de que se trata de um momento de muitas transformações, e isso é sinalizado pelas personagens quando descrevem a situação do espaço e as mudanças que começam a ocorrer:

... quando chegávamos de encontro à ribeira da praia, sentimo-nos lavados de uma poeira de eras. [...] Até que os cerros acabaram por cair, as vertentes espapaçadas sobre as linhas horizontais da terra, e os nateiros eram mantos cobertos de curtos trigaizinhos de espiga verde [...] onde um assomo de papoila e tomilho se ia casando como se tudo fosse coisa esquecida. Precisamente por onde as estradas corriam de nascente a poente e os fios de coisas eléctricas e rápidas seguiam paralelas às estradas. ... ${ }^{142}$

Antes era tudo poeira, ou seja, o ambiente era predominantemente rural, com a presença de plantações, um universo campestre; além disso, nas ruas não havia pavimentação. Mas esse cenário provavelmente haveria de ficar esquecido, porque o progresso estava a caminho, com a construção de estradas e de instalações elétricas. Afinal, como disse Sebastião Guerreiro (personagem que se mostra com um entendimento mais apurado em relação aos outros da vila),

[... ] estamos afinal diante da tal estrada de que falámos a princípio, e que há-de vir a ligar este mar do sul ao do norte, atravessando todas as províncias de portugal e da europa com um só risco nos mapas. Pois que coisa poderia ser tão grande que fosse para acabar só aqui? Diz-

${ }^{142}$ JORGE, Lídia. O cais das merendas. 4ed. Lisboa: Publicações Europa-América, 1989, p. 86-88. 
me o coração que uma estrada desta largura tem alguma coisa de muito internacional e o coração não me engana. Se calhar o futuro das grandes comunidades começa aqui e por via dos que vêm de fora. ${ }^{143}$

Pelas palavras de Sebastião, a construção da estrada seria sinônimo de progresso e poderia ser considerada como "o futuro das grandes comunidades". Acredita-se que assim seja porque, por esse meio, se constituirá o trânsito de pessoas, principalmente de fora para dentro, proporcionando certo crescimento por meio da relação estabelecida com o que vem de fora.

Talvez a construção dessa estrada proporcione ao grupo de pessoas que residem no campo um adentramento da cultura estrangeira na vila, patrocinado pela construção de um "hotel que se vai chamar Alguergue e que é todo, todo ele, quartos de aluguer". ${ }^{144}$ Ao que parece, o hotel não estava destinado aos habitantes da Redonda, tampouco fora construído por eles,

Uns dão o cimento, outros remexem o cascalho com aquele moinho. E outros ajeitam aquelas hastes de ferro que são o fundamento da segurança. Infelizmente é domingo. Mas os que mandavam na obra? Sempre será verdade que só falam inglês? Não. Ainda falam a nossa língua, mas vêm de longe. Só que nada disto se destina a gente nacional. [...] Vem de outras bandas. Esses para quem isto vai ser feito, e virão pela fama das águas do mar. ${ }^{145}$

Em outras palavras, o Alguergue foi construído para ser usufruído por estrangeiros, por pessoas que vêm de "outras bandas". Desse modo, a função dos aldeões se resumia em manter a ordem no hotel, "limpa o chão e conserva o material. Corta legumes e demais comer". ${ }^{146} \mathrm{Na}$ realidade, eles são parte desse processo, e Sebastião, dotado de esperteza, pressente que "Está na nossa mão o futuro"147, mas ele fica desesperado "perante aquela incapacidade de discernimento"148 que acomete o povo, que os impossibilita de perceber a importância daqueles acontecimentos.

A construção do hotel e, consequentemente, a ida dos estrangeiros à praia das Devícias levará os aldeões àquilo que se pode chamar de processo de aculturação ${ }^{149}$. Isso ocorre porque o povo da Redonda está vivendo num Portugal que vivencia o

\footnotetext{
143 JORGE, Lídia. O cais das merendas. Lisboa: Publicações Europa-América, 1989.

${ }^{144}$ Ibidem, p. 95.

145 Ibidem, p. 95

146 Ibidem, p.97.

${ }^{147}$ Ibidem, p. 97.

${ }^{148}$ Ibidem, p. 97.

${ }^{149}$ De acordo com o dicionário Houaiss (2001), aculturação é "o processo de modificação cultural de indivíduo, grupo ou povo que se adapta a outra cultura ou dela retira traços significativos.” (HOUAISS, Antônio. Dicionário Houaiss da língua portuguesa. Rio de Janeiro: Objetiva, 2001, p. 75).
} 
período de globalização e diz respeito à forma como os países interagem e aproximam pessoas, ou seja, como o mundo se relaciona levando em consideração aspectos econômicos, sociais, culturais e políticos.

A respeito da globalização, vale destacar o que Boaventura de Sousa Santos, em Onze teses por ocasião de mais uma descoberta de Portugal, expõe sobre a situação de Portugal. Ele diz que o país apresenta uma condição de sociedade semiperiférica em relação aos outros países europeus. Desse modo, os cinco séculos de império colonial creditaram a Portugal o papel duplo de centro e periferia, de colonizador e colonizado, ou seja, ao mesmo tempo que exercia a missão civilizadora em relação às colônias, era considerado pelos vizinhos europeus como um país "nativo e selvagem" ${ }^{150}$. No início da década de 80, com a integração na comunidade europeia, parece que surge uma possibilidade para Portugal fundamentar as bases enfraquecidas, mas, de acordo com Santos ${ }^{151}$, tal inserção coloca o país lusitano à margem dos outros países europeus. Essa posição de país semiperiférico leva Portugal, bem como o ser português, a serem considerados, como afirma Hutcheon, "o ex-cêntrico, o off-centro: inevitavelmente identificado com o centro ao qual aspira" ${ }^{, 152}$ pois está, concomitantemente, dentro e fora da comunidade europeia.

No ambiente do romance, essa globalização permite ao povo da Redonda um contato com alguns aspectos culturais e linguísticos por meio daqueles que vêm de fora. Com isso, vê-se a presença de algumas palavras estrangeiras, do inglês e do francês, utilizadas pelos rurais por influência dos estrangeiros que se hospedam no hotel. Mas o contato se dá porque o povo da Redonda acaba tornando-se empregado do hotel, e lá um homem "podia fazer de muita coisa, desde roçar e varrer a grama [...] até cuidar do motor da água" 153 e as mulheres "Essas. As que entrarem terão má vida. Sobretudo de lavação e arrumagem. Fazer camas, sacudir cobertas, limpar com ceras e solarines, tanto metal brilhante. Muitas vão ter que esfregar as vidraças que veem, em cima de uma escada de mão."154. Vê-se que, para ter acesso ao Alguergue, o povo da Redonda precisaria submeter-se a trabalhos braçais e acaba se dispondo a isso.

\footnotetext{
150 SANTOS, Boaventura P. O estado e a sociedade em Portugal (1974-1988). Porto: Afrontamento, 1990. 1995, p.65.

151 Ibidem.

${ }^{152}$ HUTCHEON, Linda. Poética do pós-modernismo: história, teoria, ficção. Rio de Janeiro: Imago, 1991, p. 88.

153 JORGE, Lídia. O cais das merendas. 4ed. Lisboa: Publicações Europa-América, 1989, p. 101.

${ }^{154}$ Ibidem, p. 101.
} 
Sebastianito Guerreiro, sabendo que os estrangeiros "vinham de todas as partes da Europa, às vezes de outros sítios do mundo..."155, tratou logo de adequar-se àquela novidade e "... aproveitou para corrigir a pronúncia. Love, mulher, repeat, Love. Assim é que se deve dizer." " No início, sentem, todos, certo deslumbramento. Sebastião com o falar diferente daqueles que chegavam e os aldeões com o verdadeiro monumento que foi construído: o Alguergue. Afinal, "está ali à espera da ligação com o mundo" ${ }^{157} \mathrm{e}$ ainda uma possibilidade de progresso. Desse modo, o novo acaba sendo incorporado sem relutância pelas personagens, e a cultura do outro vai se instalando de várias formas, não somente pela língua, mas também pelo comportamento - na medida em que aquelas pessoas começam a se valer da cultura do outro, adquirindo novos conhecimentos. Um processo inverso também ocorre, na medida em que se processa, por consequência, um esquecimento das coisas vividas e passadas. O acréscimo gradativo de palavras estrangeiras no vocabulário daqueles aldeões, ou seja, a aquisição, que parece truncada, de palavras da língua inglesa contribui para o esquecimento ou até mesmo para a perda do vernáculo lusitano.

Esses elementos podem ocasionar o enfraquecimento do sentimento de nacionalidade, tendo em vista que a língua pode ser considerada um elemento que dá força à ideia de nação, mas também pode contribuir para um distanciamento da identidade. Ao que parece, quanto mais o povo da Redonda se distancia de sua língua, de suas raízes, do espaço rural, menos possibilidades terá de construir sua identidade.

O processo de construção de identidade de acordo com a visão bakhtiniana (mostrado por Clark e Holquist em Mikhail Bakhtin) ${ }^{158}$, se dá se estiver atrelado à ideia de agregar uma cultura a outra para que se possa, depois, construir. Em $O$ cais das merendas tem-se a impressão de que os aldeões pretendem exterminar, apagar o passado, para poderem se apropriar de algo novo; ou seja, há ideia de exclusão do que se tem para assimilar o que vem de fora. Isso mostra, ainda de acordo com Bakhtin (apud Holquist) ${ }^{159}$, que a construção da identidade não pode ser pensada na ausência de uma relação com o outro, sem considerar o que já existe. E, nessa relação, deve haver uma dinamicidade, uma troca, dando ênfase "à ação, ao movimento, à energia e à performance. Para ser bem-sucedida, a relação entre mim e o outro precisa ser moldada

\footnotetext{
${ }_{155}^{150}$ JORGE, Lídia. O cais das merendas. 4ed. Lisboa: Publicações Europa-América, 1989, p. 105.

156 Ibidem, p. 105.

157 Ibidem, p. 102.

${ }^{158}$ CLARK, K. e HOLQUIST, M. Mikhail Bakhtin. São Paulo: Perspectiva, 1998.

${ }^{159}$ Ibidem.
} 
em performance coerente."160 . De acordo com o pensamento de Bakhtin, se não houver o exercício de atuar, no sentido de desenvolver uma ação, um movimento, a interação entre mim e o outro não se realizará e, consequentemente, o processo de construção da identidade, de um "eu", que Bakhtin nomeia de "self" "161, não se processará. Ao que parece, há, no povo da região rural, uma falta de discernimento, de consciência de si mesmos, e isso parece dificultar a real interação com os estrangeiros.

Vale lembrar, ainda de acordo com Bakhtin ${ }^{162}$, que o "self" se forma na sua incompletude, pois só pode existir dialogicamente, num relacionamento com outros "selves", e ainda o dialogismo, por contraste, celebra a alteridade. Desse modo, "o outro é, no sentido mais profundo, meu amigo, porque é somente do outro que eu posso obter o meu self." Mas, para isso, o desenvolvimento da consciência de quem sou se faz necessário; para a constituição do meu "self" preciso ter conhecimento sobre mim mesmo. Porém, quando há indícios da pouca existência do conhecimento sobre si mesmo, como parece acontecer com as personagens em $O$ cais das merendas, atrelado à tentativa de anular o passado (único elemento que comprova a existência daquele povo) para, possivelmente, substituí-lo pelo novo (que remete ao desconhecido), tem-se a prova de que o conhecimento sobre si se mostra muito precário. Se esse conhecimento se revela escasso, a probabilidade de construir um "self" se torna remota para os aldeões, assim como a absorção da modernização apresentada diante deles por meio da presença dos estrangeiros também é dificultada.

Nesta narrativa de Lídia Jorge, a modernização da sociedade portuguesa parece se apresentar, por meio da personagem Sebastião Guerreiro, como uma possibilidade de progresso e igualdade frente aos outros países europeus. Ao ver pela primeira vez a estrada, ele já observa, com certo deslumbramento, algo de muito internacional ali. Quando se torna funcionário do hotel e começa a fazer parte daquele espaço que remete à modernização urbana, bem diferente da Redonda, "Sebastianito Guerreiro sentia que tudo tinha acabado por modernizar-·se, que tudo pulsava já pela respiração das grandes comunidades." ${ }^{163}$ Por meio da imagem dos estrangeiros chegando à Praia das Devícias para usufruir do paraíso moderno (acreditando que ali estavam para apresentar aos portugueses uma "amostra de civilização"), a narrativa nos mostra ausência de um sentimento de igualdade entre Portugal e os outros países da comunidade europeia. Isso

\footnotetext{
${ }^{160}$ CLARK, K. e HOLQUIST, M. Mikhail Bakhtin. São Paulo: Perspectiva, 1998, p. 91.

${ }^{161}$ Ibidem, p. 91.

${ }^{162}$ Ibidem, p. 91.

${ }^{163}$ JORGE, Lídia. O cais das merendas. 4ed. Lisboa: Publicações Europa-América, 1989, p. 160.
} 
se comprova porque, para aquela gente, vinda de outras regiões, o português era considerado como um não civilizado e "entre eles corre a fama de termos todos chatos de cu até nos sovacos"

Ainda assim, a expectativa que se cria diante daquele monumento, "O Alguergue, estendido e perfilado a meio da encosta, [...] um grande marco feito de quartos, serviços, varandas, esplanadas. Tudo limpo, perfeito, pintado e irradiando mensagens invisíveis de mantenham-se, alegrem-se e amem-se ${ }^{165}$, , causa nas pessoas certa esperança de que tudo mudaria para melhor com a construção do hotel. Por outro lado, sendo o Alguergue um lugar de trânsito e de alta rotatividade, tem-se a ideia de que tudo ali é passageiro, remetendo a uma ausência de estabilidade transposta para o grupo dos aldeões habitantes ali. Por outras palavras, vê-se uma falsa ideia de que o hotel proporcionaria àquelas pessoas benefícios. Na verdade, aquela situação de contato com o externo, falsa ideia de alegria, se mostra tão passageira quanto os hóspedes alojados no local.

O fato de o hotel se apresentar com "muito vidro" é mostra disso. "Vidro transparente como qualquer um, mas umbroso e fumado para que as pessoas no seu interior não viessem a precisar de óculos de sol" ${ }^{166}$ pode remeter, em primeira instância, aos olhos do povo da vila, à ideia de luxo, de glamour. Na realidade, aquela transparência sombria, escura, faz os trabalhadores do hotel, no caso o povo da Redonda, não terem uma visão nítida da realidade. Parece que há intenção de camuflar o real para permanecerem na obscuridade, somente exercendo o papel de funcionários, de mão-de-obra acessível e obediente. Desse modo, verifica-se a dificuldade que acomete o grupo da aldeia no que se refere à construção de uma identidade. Isso ocorre porque parecem não ter consciência de si mesmos e também porque supervalorizam o que vem de fora. Para aquelas pessoas que somente vivenciavam um ambiente rural, onde a simplicidade é o que merece maior relevo, "Tudo o que cheira a outra gente tem um toque de bem-estar perto do que se imagina no céu." ${ }^{167}$ Começa, então, o povo do vilarejo a destacar somente o estrangeiro e trocar as merendas por "parties".

As merendas, "descansos breves e remordedores"168, de acordo com a visão das personagens, fazem referência a um tempo em que trabalhavam de sol a sol, nos campos

\footnotetext{
${ }^{164}$ JORGE, Lídia. O cais das merendas. 4ed. Lisboa: Publicações Europa-América, 1989, p.193.

165 Ibidem, p. 20.

166 Ibidem, p. 100.

167 Ibidem, p. 100.

168 Ibidem, p. 17.
} 
e sem hora para terminar. Era um trabalho tão exaustivo que, a cada cinco horas trabalhadas, o povo da vila fazia essa pequena pausa, mas logo voltavam para a lida e "No meio desses despojos de colheitas, as merendas eram parcas, tão frugaizinhas, como se estivesse permanentemente em tempo de guerra, acontecendo longe, mas impedindo a fartura." ${ }^{, 169}$ Em se tratando ainda das merendas, eram

essas pausas feitas num tempo tão esquecido, que para se comer uma perna de frango era preciso esperar pelo entrudo de cada ano, acompanhar a vida da ave desde o botar do ovo lá debaixo da pinta até ao termo do crescimento para que se matasse galo, uma faca espetada no gasgano. Jesus, como era. ${ }^{170}$

Logo, lembrar das merendas significava recordar o tempo de sofrimento, de dor, em que o trabalho executado era quase um trabalho escravo. A recompensa pelo desenvolvimento dessas funções era uma remuneração tão insignificante que mal dava para suprir as necessidades básicas ou para uma alimentação adequada, por exemplo. Desse modo, a miséria, ao que parece, se mostra como parte desse contexto doloroso e que, por isso, na visão dos aldeões, vale a pena ser esquecido.

Em razão dessa inspiração ruim a que remetia a merenda, o grupo rural decide que agora as pausas seriam denominadas "parties". Acreditavam, com isso, que o fato de substituírem a palavra "merenda" por um vocábulo da língua inglesa possibilitaria atribuir a esse acontecimento uma conotação positiva. Logo de início o povo da Redonda considerava que as "parties" eram diferentes, com certo requinte, e que eram "Tão bons estes domingos, estes encontros civilizados, estas conversas sobre o nosso métier, o nosso entretém, vejam, vejam, para dentro e não nos falem do passado, por favor." "171 A "party" só poderia ser assim considerada como "encontros civilizados", na visão do povo da Redonda, se fosse esquecido aquele passado de miséria, que não trazia boas lembranças. Somente dessa forma teriam a possibilidade de ascensão. Por outro lado, relembrar o passado indica ser uma forma de preservar as raízes, de cultivar a identidade, mas quando pedem para "não falar sobre o passado" vê-se que há uma intenção de extinguir a identidade que remete aos tempos ruins, o passado das merendas, para incorporar outra que inspire um futuro promissor, de bonança e fartura, que pode ser representada, no entender dos aldeões, por meio das "parties".

\footnotetext{
${ }^{169}$ JORGE, Lídia. O cais das merendas. 4ed. Lisboa: Publicações Europa-América, 1989, p. 17.

170 Ibidem, p. 17.

171 Ibidem, p. 20.
} 
Além disso, "as festas chamadas desse modo não deveriam começar pelo comer, mas pelos jogos e pelos risos, brinquezas que entretinham o convívio, provocavam a alegria e chamavam o apetite."172 Vê-se que as festas denominadas pelo nome estrangeiro aconteciam envoltas em alegria e nelas armavam-se verdadeiros banquetes: "A mesa tinha sido posta como para festa de natal, com velas vermelhas e terrinas e paninhos de renda." 173 Parece que se dava a essas festas tanta importância a ponto de serem comparadas a uma das festas religiosas de maior relevância: o Natal. Essa conotação positiva que se atribui às "parties", comparando-as com a festa de Natal, pode dar a ideia de renascimento. Pelo que mostra a narrativa, parece ser exatamente esse o sentimento do povo da Redonda nas "parties", sensação de estar renascendo com uma expectativa de que a miséria não mais fará parte do dia-a-dia deles.

O acontecimento dessa festa gerava não só uma grande expectativa no povo da Redonda como também toda uma preparação, no que se refere à vestimenta e ao comportamento:

As mulheres tinham vestido saia comprida para esse encontro, algumas com folho e fitilho a produzir um breve laço de aselha pendurada a separar as ancas, xaile com cadilho de fio brilhante [...] Os homens vestiam camisas de xadrez e punham cachimbos que sugavam nos cantos das bocas. ${ }^{174}$

O que mudou com o surgimento desses eventos não foi somente a maneira de se vestir do povo da Redonda, mas também a maneira de se comportarem. Há, de fato, uma transformação no que se refere ao comportamento, pois adquire, o povo da Redonda, durante as "parties" e também pelo convívio com os estrangeiros, bons hábitos, tais como: não falar enquanto comem, comer com a boca fechada etc. Esses bons hábitos foram aprendidos principalmente pelas mulheres. "Elas sim tinham aprendido a comportar-se em todas as situações como verdadeiras pessoas". ${ }^{175}$ Isso mostra que, na concepção dos aldeões, as "verdadeiras pessoas" são aquelas que se enquadram nos padrões do estrangeiro, usando vestimenta adequada e, consequentemente, tendo bons modos.

As merendas passam a ser chamadas não somente por "parties", como também por "evenings" e "barbecues". O uso dessas palavras estrangeiras parece ser o sinal mais

\footnotetext{
${ }^{172}$ JORGE, Lídia. O cais das merendas. 4ed. Lisboa: Publicações Europa-América, 1989, p. 19.

${ }^{173}$ Ibidem, p. 18.

${ }^{174}$ Ibidem, p. 15.

175 Ibidem, p. 119.
} 
concreto e irônico da alteração cultural que está presente no discurso fragmentado do romance. Em primeira instância, sob o ponto de vista dos camponeses da Redonda, os resultados obtidos pelas intervenções da cultura estrangeira (no que se refere à língua e aos costumes) parecem ser benéficos. Quando conseguem promover a "barbecue", parece que estão muito felizes, uma espécie de renovação:

Era como se fôssemos aniversariantes de dezoito anos, meus amigos, e por conjugação do calendário, todos estivéssemos a festejar o mesmo dia. Era ou não era? Ai Sebastianito, como somos felizes. Consegui promover um barbecue. E Zulmirinha Santos largou o grupo para abraçar Sebastião Guerreiro pela cintura, encostar a cabeça, parecendo mesmo os grupos de amigos... ${ }^{176}$

Estavam tão felizes os aldeões que parecia "mentira terem vivido num tempo em que era impossível fazer parties, evenings, barbecues"177, achavam até que estavam mais evoluídos.

Eles ficam tão motivados e entusiasmados diante das novidades que acreditam na possibilidade de deixar para trás todo um passado doloroso, para seguir um novo percurso, pode-se dizer, talvez, em busca de uma nova identidade. Mas, pelo que se nota na narrativa, Lídia Jorge parece apresentar uma sociedade ruída pela aculturação e que se coloca em dúvida entre lembrar o passado (cultivando a memória) ou deixar esse passado cair no esquecimento (considerando somente o presente influenciado pela globalização). De qualquer forma, essa ambivalência entre o lembrar e o esquecer pode ocasionar numa (des)construção da identidade portuguesa, e essa questão, pelo que se nota no discurso narrativo, parece estar evidenciada no romance.

\section{1 - O percurso identitário das personagens}

Sobre o processo de construção da identidade, pelo que se observa no romance, parece que as personagens atribuem a esse percurso a substituição (pelo que percebe com prazer) do espaço rural (pois este representava a vida dura do campo) para se submeterem às ordens e aos caprichos aos quais eram submetidos quando resolveram migrar para a praia das Devícias, que pressupõe o urbano. Esse rompimento com a vida campesina pode ocasionar o apagamento de suas identidades, mesmo que gradativamente, em função do esquecimento do passado. O esvaziamento da memória

\footnotetext{
${ }^{176}$ JORGE, Lídia. O cais das merendas. 4ed. Lisboa: Publicações Europa-América, 1989, p. 164.

${ }^{177}$ Ibidem, p. 170.
} 
pode ser registrado na sensação de perda apontada primeiro por Pinária, uma das personagens, e depois por Aldegundes:

Juro. Juro que não me lembro se é a galinha que põe o ovo, nem se é a parreira a árvore que dá as uvas. Como eu ando. E enquanto Pinaira parecia ter terminado seu aranzel. Aldegundes Breda estava morta por matar aquela curiosidade de um mundo que tinha vivido na Redonda. Então quantas vezes se semeia ao ano? Precisamos de chuva para que as plantas nasçam? ${ }^{178}$

Quando uma das personagens aponta para o esquecimento dizendo ter "curiosidade de um mundo que tinha vivido na Redonda", é possível perceber que aquilo que representa o novo parece ser seriamente incorporado no contexto dos aldeões. Sendo assim, aos olhos do povo da Redonda, o fato de incorporar a cultura do estrangeiro significa que, a partir daquele momento, passam a possuir uma nova identidade, que lhes propiciará certo desenvolvimento, progresso, uma vida cheia de perspectivas.

Para que ocorra de fato a incorporação do novo, com o intuito de construção de uma identidade primeira ou nova, que seja, é necessário que o indivíduo tenha consciência de si mesmo. O solo para a realização dessa identidade é a alteridade, ou seja, a necessidade do indivíduo de existir para o outro e o desejo de, talvez, assumir o lugar do outro. Mesmo quando viviam na Redonda, isolados e sem se comunicarem com outras pessoas que habitavam fora daquela espécie de sítio em que viviam, os camponeses não demonstravam conhecimento de si, e isso parece ocorrer provavelmente pela quase ausência de contato com o mundo exterior à Redonda. Pelo que se nota, já existia, por parte dos aldeões, ainda quando habitavam a Redonda, uma precariedade no que se refere ao conhecimento de si mesmos. O que parece que se tem, de acordo com as palavras de Bakhtin, são "identidades unitárias"179, em que nos deparamos com a realidade de que eu, de algum modo, não corresponde a mim.

Essa ausência de correspondência evidencia-se em $O$ cais das merendas, porque aquele povo não se reconhece em si mesmo. Além disso, Bakhtin ainda diz que "O mundo é sempre outro para a consciência, de modo que a alteridade está na natureza humana." 180 Isso mostra que "Ser significa comunicar-se dialogicamente. Quando o

\footnotetext{
${ }^{178}$ JORGE, Lídia. O cais das merendas. 4ed. Lisboa: Publicações Europa-América, 1989, p. 244.

${ }^{179}$ CLARK, K. \& HOLQUIST, M. Mikhail Bahtin. São Paulo: Perspectiva, 1998, p. 106.

${ }^{180}$ Ibidem, p. 108.
} 
diálogo termina, tudo termina." ${ }^{181}$ Embora exista um contato entre os que habitavam a Redonda e os estrangeiros, não se pode considerar que isso seja um "comunicar-se dialogicamente", porque não se percebe um diálogo, uma interação, uma troca. Percebese um mero contato e isso não é suficiente para que se estabeleça um diálogo.

Sendo assim, ao que parece, a primeira sensação que o povo da Redonda manifesta (a sensação de que a presença do estrangeiro seria suficiente para tirá-los daquela visão de mundo restrita e inseri-los no mundo globalizado) parece não se confirmar, porque, mesmo com a presença do estrangeiro e a vivência, agora num ambiente urbano, ainda há a sensação de desnorteamento. Essa falta de rumo os faz sentir saudades das merendas. Porém vale lembrar que a saudade não parece ser consequência da falta de norte, mas sim algo que faz parte do povo português. Como se o passado representasse o tempo presente.

Voltar ao passado, como diz Eduardo Lourenço em Mitologia da saudade ${ }^{182}$, não é um ato neutro, mas essa regressão constitutiva da memória pode ser vivida apenas como simples alusão, mero sinal endereçado aos acontecimentos ou aos sentimentos que pulverizam. Em $O$ cais das merendas, ao que parece, o povo da Redonda a todo o momento está fazendo alusão a um passado que os remete ao tempo das merendas, relembram os acontecimentos e sensações fazendo-os permanecerem naquele tempo. Mesmo as muitas novidades e a variedade de alimentos e bebidas não tiravam daquela gente o gosto de saudade da boca "Vai-se-nos acumulando esta saudade das coisas antigas, junto das papilas da boca durante a semana. Por isso não tenham medo de regressar à bucha que a chamamos sandes, meus amigos. Gostamos delas realmente de pão fofo e linguiça queimosa de vermelho" 183

$\mathrm{Na}$ realidade, os portugueses, ainda sob o ponto de vista de Lourenço, inventam uma maneira de voltar ao passado, ao seu em particular. Isso não se dá de forma nostálgica, nem tampouco melancólica.

É simplesmente saudosa, enraizada com uma tal intensidade no que ama, quer dizer, no que é, que um olhar para o passado no que isso supõe de verdadeiro afastamento de si, uma adesão afetiva ao presente como sua condição, é mais da ordem do sonho que do real. É esse

${ }^{181}$ CLARK, K. \& HOLQUIST, M. Mikhail Bakhtin. São Paulo: Perspectiva, 1998, p. 108.

${ }^{182}$ LOURENÇO, E. Mitologia da Saudade. São Paulo: Cia das Letras, 1999.

${ }^{183}$ JORGE, Lídia. O cais das merendas. Lisboa: Publicações Europa-América, 1989. p. 117. 
lugar de sonho, esse lugar ao abrigo do sonho, esse passado-presente, que a "alma portuguesa" não quer abandonar. ${ }^{184}$

Essa maneira portuguesa de voltar-se ao passado se evidencia no romance em questão. Parece que pretendem caminhar para o progresso tentando se adequar ao novo cenário de Portugal com a chegada da globalização, mas há algo muito mais forte do que a própria natureza daquele povo enraizado na conduta deles que não os deixa avançar. Por esse motivo, acabam se perdendo em meio ao progresso, não tendo outra alternativa se não a tentativa de retorno ao passado. Vale lembrar que algumas pistas no romance nos mostram que nesse passado sugere a não garantia de reencontro consigo mesmos, porque, quando lá estavam, vivendo a época das merendas, também não tinha consciência de si mesmos. Isso mostra que, no romance, pode haver, entre as personagens, um processo de perda, ganho e perda novamente da identidade, pois não se reconhecem a si mesmos no passado, nem tampouco no presente.

Ao verificar o comportamento das personagens, nota-se que, embora o reconhecimento de si pareça não se evidenciar, há indícios de que um desejo de construção de identidade permeie o caminho delas. Esse desejo parece estar presente no grupo de personagens do romance, composto por homens e mulheres, de maneiras diferentes, de acordo com o nível de consciência apresentado por cada uma. Apresentase no romance um grupo de personagens composto por homens e mulheres que se mostra com graus de consciências diferenciados.

Sabe-se que, no universo das personagens femininas, o não reconhecimento de si talvez possa estar mais em evidência pela condição de subalternidade que historicamente foi imposta à mulher, e será este o foco da análise que aqui se propõe, a construção da identidade das personagens femininas. Porém, as personagens masculinas também merecem atenção, porque além de dividirem o mesmo espaço com as personagens femininas, a presença do masculino pode contribuir significativamente para que o feminino construa sua identidade porque é por meio da interação com o outro que a consciência de si se processa.

Entre as personagens estão: Zulmira Santos, Valentina Palas, Pinaira e Aldegundes Beira (grupo de mulheres que residiam na Redonda); em destaque estão: Sebastião Guerreiro, Santanita Trigal, Rosária, Belisanda Maria (mãe de Sebastião) e

\footnotetext{
${ }^{184}$ LOURENÇO, E. Mitologia da Saudade. São Paulo: Cia das Letras, 1999, p. 14.
} 
Miss Laura; entre os homens estão: Pai Patroços, Edmundo Breba (gostava de Rosaria), Augusto Folhas, Rui Seladinha e Simão Rosendo.

\section{2 - Da Redonda a Devícias: momento de transição}

Assim como os outros, o primeiro grupo de personagens, composto somente por mulheres, Zulmira Santos, Valentina Palas, Pinaira e Aldegundes Breda, estava ansioso para encontrar o novo, representado pelo suposto progresso que chegaria à praia das Devícias com a construção do hotel Alguergue. No imaginário do povo da Redonda, não somente das mulheres, a convivência com o urbano talvez pudesse representar ausência de um trabalho tão árduo como ocorria na Redonda (cortar cana, colher trigo, um trabalho rural). De fato, o trabalho no hotel era um pouco mais leve que o trabalho no campo, mas os camponeses não tiveram, trabalhando no hotel, a vida confortável que imaginavam que teriam. A despeito disso, havia, no primeiro momento, uma expectativa muito grande por parte do povo da Redonda. Por esse motivo, "A décima nona foi anunciada não como merenda, coisa que lembraria figos, mas já como party, ajuntamento que falava festa, doces gestos, meus amigos." 185

Trata-se de um momento muito especial tanto que "a própria Zulmira Santos se apercebeu do significado desse passo, incansável pelo sucesso do encontro, o rigor das coisas, a combinação dos sortidos, a pontualidade das horas." ${ }^{186}$ Zulmirinha, "empregada do shopping"187, preparou tudo para a primeira party. Ela era "a nossa organizadora, mãe daquele party, madrinha das festas, mulher honrada sobre a qual ninguém tinha assim, do tamanho desta ponta de unha, para se lhe dizer, a não ser elogios..." ${ }^{188}$. Todos se preparavam para o evento não somente as mulheres, vestindo-se com suas melhores roupas, mas também os homens. Pareciam que estavam todos felizes porque Zulmirinha "foi capaz de impedir o pior, aqueles desacatos tradicionais e tristes. Graças ao esforço de alguns, o bem era agora colectivo, e tudo já se encontrava em ordem, tão calmo e o.k. ${ }^{189}$

A felicidade era visível porque os aldeões agiam diferente e tinham também adquirido bons modos:

\footnotetext{
${ }^{185}$ JORGE, Lídia. O cais das merendas. Lisboa: Publicações Europa-América, 1989, p. 15.

${ }^{186}$ Ibidem, p. 15.

${ }^{187}$ Ibidem, p. 26

${ }^{188}$ Ibidem, p. 25-26.

${ }^{189}$ Ibidem, p. 25.
} 
Mas as mulheres, cuidosas. Assentes as almofadas da nádega sobre as polpas de renda e sumaúma, somo se Zulmirinha estivesse presente. Imóveis falando. [...] Elas sim, tinham aprendido a comporta-se em todas as situações como verdadeiras pessoas. Pinaira ouvia. A comer de bocas fechadas para que não se visse o adejas da língua contra os dentes limpinhos. [...] E Zulmirinha Santos ausente... ${ }^{190}$

A convivência com o estrangeiro fez com que grande parte das pessoas da Redonda, principalmente as mulheres, adquirissem novos costumes. Isso se deu por intermédio de Zulmirinha, que, pelo que parece, ajudou aos aldeões com esse novo desafio. Há indícios de que as mulheres se habituaram rapidamente com o novo contexto a ponto de agirem da mesma forma, mesmo quando Zulmirinha não estava por perto.

É provável que a ausência de Zulmirinha remeta a certa reclusa. O discurso dessas mulheres deixa entrever que elas estavam cada vez mais se aproximando dos costumes dos estrangeiros e se afastando dos próprios costumes. Essa atitude pode, talvez, levar essas mulheres à alienação, pois parecem abdicar de suas próprias raízes para se apropriarem de uma cultura que não lhes pertence. Talvez esse afastamento momentâneo de Zulmirinha possa representar certa cautela, para que não seja totalmente corrompida. Parece que a empregada do hotel já não se comportava da mesma maneira e também estava perdendo alguns hábitos.

Pode ser que esse seja um momento de reflexão para Zulmirinha, quem sabe um início de conscientização. Por isso, Simão diz: "Se Zulmirinha quis ficar em casa, então que deus a conserve. Queremos gente que saiba beber e se dispa sem trejeitos de medo, gente." ${ }^{191}$ Zulmirinha se afasta naquele instante, mas retorna e é tomada por uma monotonia e "estava a achar aquilo tão absurdo que se pôs a bocejar de desinteresse". ${ }^{192}$

Como se sabe, parece que há um grande esforço por parte de todos, como disse Pinaira (outra empregada do hotel), "para só falarmos de conversas ligeiras, palavras

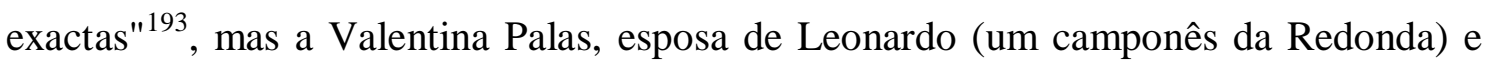
funcionária do hotel, que cuidava da limpeza, "apetecia pensar no meio desse party" ${ }^{194}$. No início da narrativa, Valentina, assim como as outras personagens, está maravilhada e esperançosa de que havia um futuro promissor naquele novo espaço que passavam a habitar. Porém, em meio à primeira party, mesmo "com a vida a tombar cada vez mais

\footnotetext{
${ }^{190}$ JORGE, Lídia. O cais das merendas. Lisboa: Publicações Europa-América, 1989, p. 119.

191 Ibidem, 121.

${ }^{192}$ Ibidem, p. 233.

${ }^{193}$ Ibidem, p. 25.

${ }^{194}$ Ibidem, p. 25.
} 
mansa, mais terna e mais pombinha. Num ponto tal de equilíbrio que nem maralho de bebedeiras e nem exéquias" ${ }^{195}$, surge para Valentina a lembrança de Rosária. E este ritual de quem chora a morte de um ente querido surge na faxineira repentinamente.

O trabalho no hotel e a nova rotina de Valentina fazem com que ocorram algumas mudanças em seu comportamento e também na sua aparência física. Era uma mulher obesa, robusta, que começa a emagrecer "vocês verão a minha cinturinha" ${ }^{196}$ e também a tomar calmantes porque parece estar perdendo o sono "agora eu compro na farmácia uns pós [...] Pego num frasco [...] Meto duas colheres desse pó, meio litro de água [...] abro a boca para não tocar na língua e vai de um trago, à noite, antes de adormecer." ${ }^{197}$ Entre as mudanças que estavam ocorrendo com Valentina e a sucessão de parties, ela começa a se cansar:

Era na hora do descanso e as paredes brancas caiam a pique sobre o solo sem novidade nenhuma. O mar? O mar chateava de repetir as mesmas gradações. Já chega. Suspirou Valentina agora emagrecida e pálida, os olhos a aumentarem e o queixo a diminuir. Eu gostava. Dizia ela. Eu gostava de ser como certas pessoas que têm a capacidade de se esquecerem de tudo até de quem são, e no meio desse esquecimento só pensam em revolta. Eu gostava. [...] Estou cansada, tenho a alma cheia de nódoas negras desta luta comigo mesma. Tão cansada. ${ }^{198}$

Pelo que se nota, as palavras de Valentina sugerem que o marasmo e a mesmice começam a se fazer presentes e os dias acabam passado "sem novidade nenhuma". Sabe-se que as culturas são suscetíveis de mudança e, no caso do povo da Redonda, essa mudança ocorreu quando migraram para a praia das Devícias. Porém Valentina e os outros não poderiam prever que tal mudança pudesse ser prejudicial, a ponto de causar certo conflito interno, prova disso é o desejo que Valentina demonstra de querer ser "como certas pessoas que têm a capacidade de se esquecerem de tudo até de quem são". Isso causa na personagem uma exaustão por conta dessa "luta comigo mesma", como ela diz. Está evidenciada, no trecho, uma crise de identidade. Valentina se mostra estar entre o que ela pensa ser (uma mulher do campo que talvez deva preservar suas raízes) e o que ela deve ser (uma mulher que, ao ter contato com outra cultura, deve alterar o seu comportamento).

\footnotetext{
${ }^{195}$ JORGE, Lídia. O cais das merendas. Lisboa: Publicações Europa-América, 1989, p. 25.

${ }^{196}$ Ibidem, 117.

${ }^{197}$ Ibidem, p. 176-177.

${ }^{198}$ Ibidem, p. 214-215.
} 
Sobre essa questão ser/dever ser, Onésimo Teotónio Almeida, em seu artigo intitulado "A questão da identidade nacional na escrita portuguesa contemporânea", diz que "o problema torna-se intrincadamente difícil quando as visões de o que se é se entrelaçam com as do deve ser, do pode ser ou as do tem de ser ainda que não se possa $s \hat{e}-l o^{\prime \prime}{ }^{199}$. É provável que, no romance, Valentina e os outros passem pela mesma situação de ficarem em dúvida entre o que são e o deveriam ou poderiam ser, mas para que ocorra esse entrelaçamento, ainda de acordo com Almeida, é importante "monitorar, verificar e corrigir se necessário, as visões e concepções que um povo tem de si e os outros dele." ${ }^{200}$,

Pelo que se nota, mesmo quando estavam na Redonda, sem terem contato com a cultura estrangeira, os camponeses não demonstravam ter uma concepção de si. Acredita-se que, por esse motivo, o entrosamento com os estrangeiros tinha se tornado ainda mais difícil. Isso, consequentemente, gerou um mal-estar que se mostra bastante significativo, no que se refere ao conhecimento de si mesmo, conforme foi demonstrado por meio da fala de Valentina.

Esse fato desperta na personagem certa nostalgia e vontade de retornar ao passado, de voltar ao tempo das merendas: "E Valentina lembrando-se das três primeiras merendas. Tanto tanto que falámos dos astros e dos seus mistérios nessas tardes de viagem a este local deserto. Aquilo é que era um tempo. [...] E estava tudo nesse tempo tão bem feito..." ${ }^{201} \mathrm{O}$ passado que remete às merendas faz Valentina relembrar Rosária (a personagem que fica dividida entre permanecer no passado, vivendo na Redonda, ou se adequar ao presente/futuro, vivendo na praia das Devícias). Ao lembrar essa personagem, Valentina, involuntariamente, retornaria ao tempo das Merendas, quando viviam os aldeões no Sítio Redonda, em condições muito precárias. Por esse motivo, em princípio, todos evitavam essa lembrança, inclusive Valentina.

Ao perceber que fora acometida por uma fraqueza e essa se instala exatamente quando está situada no tempo das "parties", ou seja, quando se torna empregada do Alguergue, residindo na praia das Devícias, Valentina percebe que talvez fosse bom lembrar Rosária, ou seja, retornar ao tempo das merendas, porque talvez buscando as suas próprias raízes pudesse buscar um conhecimento maior sobre si. "Só para que se

\footnotetext{
${ }^{199}$ ALMEIDA. O. T. A questão da identidade nacional na escrita portuguesa contemporânea, 1991, p. 496-497.

${ }^{200}$ Ibidem, p. 496.

201 JORGE, Lídia. O cais das merendas. Lisboa: Publicações Europa-América, 1989, p. 232.
} 
saiba o que Valentina poderia dizer se não sentisse uma fraqueza tomá-la a partir das vistas. Que viesse Rosaira a correr, largasse as mudas, o balde e viesse." 202

A vontade de que Rosária volte, desperta em Valentina certo desejo: "Valentina queixava-se tanto e pedia tão aflitivamente, Leonardo, Leonardo. Leva-me até às sentinas do mar. Parece que só ai ficarei aliviada [...] Valentina a querer andar agarrada às paredes, devagar, tendo perdido um rumo." ${ }^{203}$ Mesmo frágil, Valentina parece se sentir melhor em qualquer lugar em que pudesse esquecer a lembrança de Rosária até mesmo numa sentina, que em sentido figurado, de acordo com o dicionário Houaiss ${ }^{204}$, quer dizer lugar imundo; ambiente corrompido. Somente assim, de acordo com a fala da personagem, "ficaria aliviada". Valentina vai até a sentina e de lá "não sairia mais" ${ }^{205}$.

Após o sumiço de Valentina não se tem mais notícias dela e, com isso, pode-se observar que parece ter desistido de resgatar a si mesma, ou seja, sua identidade. Valentina aparenta ter-se cansado de viver naquele ambiente repleto de lembranças de Rosaira (lembranças essas que podem representar, involuntariamente, um retorno ao passado, ao tempo das merendas) sem ter forças nem condições para retornar às suas raízes, a fim de iniciar um conhecimento de si e, consequentemente, partir para a construção de sua identidade. Valentina encontra na sentina um refúgio porque não tem forças para ir adiante, para seguir rumo ao conhecimento de si.

Durante a narrativa, Valentina dá indícios de que o passado na Redonda nunca deixou de fazer parte de seu cotidiano, mesmo quando já habitava a praia das Devícias, e que provavelmente não ficaria esquecido na memória. Ela comentava sobre o passado com Sebastião Guerreiro e ele "a ouvir as loucuras de Valentina Palas que falava das coisas do tempo de Belisanda Maria, tão ida tão ida, de um tempo tão parvo que se tinha de riscar da memória." ${ }^{206}$ Pelo que se percebe, Valentina relembrava não somente o passado das merendas quando remetia a Rosária, mas também um passado remoto "do tempo de Belisanda Maria" (mãe de Sebastião, uma mulher muito idosa). Além disso, Sebastião a trata como louca.

O culto ao passado se faz muito presente nessa narrativa, assim como também é recorrente no primeiro romance de Lídia Jorge, O dia dos prodígios. Cultuar o passado, como já foi observado, parece fazer parte da cultura portuguesa e isso é perceptível no

\footnotetext{
202 JORGE, Lídia. O cais das merendas, 4ed. Lisboa: Publicações Europa-América, 1989, p. 242.

${ }^{203}$ Ibidem, p. 248.

${ }^{204}$ HOUAISS, A. Dicionário da língua portuguesa. Rio de Janeiro: Objetiva, 2001.

${ }^{205}$ JORGE, Lídia. Op. cit. p. 251.

${ }^{206}$ Ibidem, p. 139.
} 
comportamento das personagens. Essa forma de manter-se preso ao passado parece acentuar, no que se refere aos dois romances da autora, a dificuldade das personagens em se adequarem ao novo e, ainda, a precariedade que se evidencia no estabelecimento da relação com o outro no universo em que vivem e, também, com o exterior.

Em $O$ dia dos prodígios a complexidade dos personagens é no sentido de se adaptarem ao novo contexto regado por uma Revolução (a de 1974) que libertou Portugal de uma ditadura acirrada. Aqui, em $O$ cais das merendas, a dificuldade do enquadramento das personagens deve-se ao novo contexto português pós-revolução de 1974, em que a globalização causa um considerável impacto na cultura dos lusitanos. Por conta desses novos contextos, estabelecer relação com o outro, ou seja, conviver tendo que levar em consideração essas mudanças parece algo conflituoso tanto para o povo de Vilamaninhos em $O$ dia dos prodígios, assim como para os camponeses da Redonda em $O$ cais das merendas. O comportamento deles acaba causando certa estagnação, certa mesmice que faz as personagens perderem a percepção até mesmo das pequenas coisas.

Essa deficiência instrutiva que parece estar presente nas narrativas pode ser percebida pelas próprias personagens. Zulmira Santos, por exemplo, personagem de $O$ cais das merendas acreditava que eles, e ela inclusive, não tinham conhecimento sobre nada. Ela chega a essa conclusão porque

\begin{abstract}
havia puxado de duas revistas e mostrado que entre o que viam e estava ali não havia diferença, nós é que não estávamos habituados a ver modelos ao vivo, nem a conviver com os célebres e viajados, parecíamos loucos mentais assomando as cabeças, pelo átrio, dizendo ai ai, impando por uma ideia de gozo e pena. My goodness, que imbecis que éramos. Não merecíamos ser empregados de shopping, agindo assim, nem de coisa nenhuma. ${ }^{207}$
\end{abstract}

A precariedade de informação se evidencia quando Zulmira diz que eles não têm conhecimento sobre revistas (são magazines que circulam por vários países por conta da globalização). Zulmira, referindo-se aos hóspedes, diz também que não eram capazes de "conviver com os célebres e viajados" e, por conta disso, não mereciam ser empregados de "coisa nenhuma". A fala de Zulmirinha somente ressalta o desconhecimento dos aldeões.

Pinaira e Aldegundes Breba, assim como as outras personagens, pareciam também ter perdido aquele entusiasmo inicial. A euforia tinha se transformado numa

${ }^{207}$ JORGE, Lídia. O cais das merendas. Lisboa: Publicações Europa-América, 1989, p. 150. 
espécie de mansidão e essa falta de agitação causa nas personagens certo êxtase, como se perdessem a consciência da própria existência. Pinaira "abriu os olhos e ficou a ver as nuvens passarem lentas, às cores, vindas do mar, muito mansas e a caminharem para terra, como barcos desancorados a desfazerem-se no caminho do cais." ${ }^{208}$ Ela ficava ali parada e parecia estar sem perspectiva. Além disso, Pinaira apresenta-se muito magra "era-o por condição. Tinha mantido os canelos magros do plantio da fava, o ventre liso das caminhados dos tojos, dedicada agora às limpezas do corrimão" ${ }^{209}$ Essa magreza pode representar certo desgaste, que talvez tenha sido ocasionado pelas transformações que sofrera seu cotidiano com a mudança para o hotel.

Enquanto Pinaira emagrecia e Valentina tomava calmante para dormir, Aldegundes Beira, ao acordar de uma das "parties", notou que havia perdido a memória

Estava Aldegundes Beira a ver a vida a andar à roda da cabeça e não sabia como para ali tinha vindo nem quem era. Ai de mim, como me chamo? E onde estou? Serei casada ou solteira? Em cada pergunta que fazia punha Aldegundes Beira o ímpeto de uma aflição, e cravava os olhos em todos como se alguém por brincadeira lhe tivesse escondido a identidade dentro da algibeira. ${ }^{210}$

Em contrapartida, Pinaira

pôs-se a dizer para Aldegundes, como se a repreendesse com severidade, que se lembrava de tudo tão bem. Que a ela o sono até tinha a vantagem de lhe avivar as coisas esquecidas. Fosse do que fosse, meu deus, acabava de sonhar com Rosária, só para que visse o contraste." 211

E Aldegundes responde: "Sendo assim, ainda bem que não quis homem para não perder a memória"212

O diálogo entre as personagens mostra, por meio da primeira fala de Aldegundes, que as "parties" não traziam a eles (ao povo da Redonda) o benefício que esperavam. Adquiriram, os camponeses, ao adentrarem esse universo regado pela globalização, um esquecimento de si, uma perda da identidade. Isso causa, como diz Aldegundes, "aflição" e, talvez, uma sensação de esvaziamento. Por esse motivo Aldegundes tinha medo de dormir.

\footnotetext{
${ }^{208}$ JORGE, Lídia. O cais das merendas. Lisboa: Publicações Europa-América, 1989, p. 170.

${ }^{209}$ Ibidem, p. 177.

${ }^{210}$ Ibidem, p. 175 .

${ }^{211}$ Ibidem, p. 178.

${ }^{212}$ Ibidem, p. 178.
} 
Em contrapartida, o sono, para Pinaira, "tinha a vantagem de lhe avivar coisas esquecidas". Lembrava-se de Rosária, a representação do resgate das raízes dos aldeões. Aldegundes acredita que a lembrança de Pinaira está relacionada ao fato de não haver, na vida da faxineira do hotel, a presença de uma figura masculina. A fala de Aldegundes dá indícios de que a convivência com um homem pode prejudicar a mulher no que se refere ao desenvolvimento da identidade feminina. Isso pode ocorrer, em se tratando do contexto do romance, porque a mulher, principalmente aquela que habitava as zonas rurais, ainda se mostrava submissa ao homem. Essa condição de mulher oprimida provavelmente agravaria ainda mais a "perda da memória".

Sabe-se que o desconhecimento de si (pela condição de submissão da mulher) pode ficar mais evidenciado. Por esse motivo, acredita-se que a construção da identidade feminina se mostra como um complicador ainda maior. Mas não se pode deixar de dizer que, aqui, em $O$ cais das merendas, tem-se, em primeira instância, a busca de uma identidade coletiva, e a busca da identidade feminina, por parte de algumas personagens, parece estar embutida nesse contexto.

Há momentos na narrativa em que Pinaira parece querer assumir o papel de "relatora de segredos" ${ }^{213}$. Embora nunca se fizesse notada por sua opinião, Pinaira sempre expunha o seu ponto de vista, deixando virem à tona seus pensamentos e dando indício de uma conscientização de si. Mas chega um momento em que ninguém mais se importa com as revelações dela. "Estava louca aquela mulher, e não tinha vergonha nenhuma de falar assim de Rosária, tratando-a por cega e surda, ela que via e ouvia tão bem" $^{214}$.

Pinaira parecia querer ignorar suas raízes quando falava mal de Rosária, mostrando não se importar com o passado. Mas pode ser que a personagem não estivesse em condições de retornar ao passado e buscar a consciência de si. As circunstâncias, por todo o histórico de vida da mulher, contribuem para que a busca da identidade seja dificultada. Talvez o desejo de resgatar essa identidade exista, mas as dificuldades são muitas, parece que há uma falta de rumo das personagens.

Esse desnorteamento e desânimo também acometem Aldegundes, "estranha, a ouvir, não se importava naquela tarde com as notícias das rendas, nem dos pontos, como se se tivesse esquecido da palavra agulhas." ${ }^{215}$ Antes cultuava-se uma prática de tecer

\footnotetext{
${ }^{213}$ JORGE, Lídia. O cais das merendas. Lisboa: Publicações Europa-América, 1989, p. 242.

${ }^{214}$ Ibidem, p. 246.

${ }^{215}$ Ibidem, p. 178.
} 
que "se fazia um silêncio tão grande entre as mulheres que era agora possível ouvir o ranger das agulhas tecendo as rendas." ${ }^{216}$ Agora, no tempo das "parties", até mesmo o bordado, atividade quase sempre restrita às mulheres, que "tinha como objetivos ornamentar e embelezar a casa, as roupas, os enxovais e, algumas vezes, era geradora de renda familiar" ${ }^{217}$, não desperta mais o interesse de Aldegundes. Além disso, o bordar, de acordo com Ziani, se mostra atualmente como linguagem que vem sendo difundida "estimulando reflexões e representações" ${ }^{218}$ Pode-se dizer que o bordado possibilita a experiência do contato da pessoa consigo mesma, com suas vivências, numa espécie de libertação.

Vale lembrar que, em $O$ dia dos prodígios, acredita-se que foi, principalmente, o bordado que despertou na personagem Branca Volante o prenúncio da conscientização de si mesma. O bordado lhe deu forças para enfrentar o marido; para resgatar o dom de adivinhar que estava adormecido, enfim, representou, para Branca, um recomeço. Acredita-se que, com Aldegundes, não seria diferente, mas o contato com o universo da globalização parece ter interrompido essa possível libertação.

Santanita Trigal, esposa de Sebastião Guerreiro e mãe de Rosária, ao contrário das outras personagens, não consegue se adaptar ao novo ambiente, o urbano, representado pela praia das Devícias. Ela não consegue acompanhar as transformações que ocorrem em Portugal por conta da presença dos estrangeiros e percebe que aquele contexto não inclui pessoas como ela. Santanita acaba voltando para o sítio da Redonda com pai Patroços (um senhor que habitava a Redonda) e os filhos:

Pai Patroços de chapéu palmares na cabeça olhava a altura das últimas janelas. Conta lá os pisos que me encadeia a vista a partir do segundo. Mas era como se dissesse. Acabaram-se as três merendas. Não voltamos mais. [...] Um grande desejo de partir sem levantar um pé, nem mexer um dedo. Só que Santanita Trigal, ao montar sobre a mula que tinha ido buscar de sob uns pinheiros, puxou de um lenço de algibeira para dizer. Não escrevas mais carta nenhuma, que a verdade é outra. ${ }^{219}$

Eles vão embora dali com o intuito de não mais voltar. Pai Patroços faz menção ao término das merendas e Santanita pede para Rosária não enviar mais cartas. Isso mostra que pai Patroços acredita que, retornando a Redonda, possa relembrar o tempo

\footnotetext{
${ }^{216}$ JORGE, Lídia. O cais das merendas. Lisboa: Publicações Europa-América, 1989, p. 170.

${ }^{217}$ ZIANI, Beth. Tempo de Bordar. In: Revista interdisciplinar de gestão social set. / dez. 2013 v.2, n.3, p. 191-203, p 192.

${ }^{218}$ Ibidem, p. 192.

${ }^{219}$ JORGE, Lídia. O cais das merendas. Lisboa: Publicações Europa-América, 1989, p. 210.
} 
das merendas, ou seja, retornar ao passado. Santanita parece querer cessar a comunicação com a filha, para que possa retornar as suas raízes, porque era por meio das cartas que as notícias sobre a praia das Devícias chegavam até Santanita.

Santanita Trigal representa o passado, a vida sofrida e rural. Segundo o marido, "cheirava a bafio de farelo de trigo e porqueira, suor de cabeça por lavar" ${ }^{220}$. Tinha também um "fiapo de bigode negro e teso como coisa de gato a enfeitar o canto da boca". 221 Era avessa à compreensão e beleza e motivo de constrangimento para Sebastião Guerreiro por causa de sua simplicidade e de seu jeito de mulher do campo.

Santanita ora Cagaça ora Trigal, representava a desatualização, a ignorância e o marasmo cultural e todas as "coisas ultrapassadas". Ela é uma das poucas personagens que não trabalhavam no hotel, talvez porque não se tenha deixado corromper pelo surgimento dos estrangeiros ou porque não tenha conseguido acompanhar o progresso que todas aquelas transformações representavam. Ela continua no ambiente rural, permanecendo na Redonda com seus dois filhos. Talvez possa ser considerada, num primeiro momento, a personagem que tem o grau de consciência menos elevado de todas.

Sebastião Guerreiro, marido de Santanita, era o que mais abominava as atitudes da esposa. Isso ocorre talvez por influência do contato que ele mantinha com os estrangeiros, sobretudo com Miss Laura, inglesa de formas prensadas e lisas, que representa, para Sebastião, o novo, o moderno. Ele fica muito aborrecido quando presencia Santanita em exibição junto às ondas, causando espanto em todos os banhistas. A mulher de Sebastião Cagaça

Tinha os músculos de todo o corpo muito à mostra, como raízes de árvores, e dos pés aos joelhos, das mãos aos cotovelos, era castanha como figo seco e torrado. Também da testa ao pescoço, e ainda um pequeno triângulo que ficava acima dos seios [...] My goodness. Pensou Sebastião para si, [...] sobretudo porque sua mulher se lavava de cócoras, com uma combinação de florinhas colada às ancas, e procurava desencardir-se de qualquer nódoa com um pedacinho de sabão azul, no dá-lhe, corpo acima corpo abaixo. Até ao buraco das orelhas onde metia o seu dedo mínimo para se desentupir. Ansiandose e ameaçando cair ao mar [...] Gente alta e loira passava como por acaso, e levando máquinas a tiracolo, disparando-nas discretamente [...] E Santanita de costas viradas, serena na sua inquietação de se sustentar e fazer limpeza ... ${ }^{222}$

\footnotetext{
${ }^{220}$ JORGE, Lídia. O cais das merendas. Lisboa: Publicações Europa-América, 1989, p. 200.

221 Ibidem, p. 129.

222 Ibidem, p. 207-208.
} 
A presença de Santanita era mesmo uma afronta para Sebastião, a ponto de lhe custar crer que estivesse ligado por casamento e procriação a essa mulher. Parece que ela percebe a fúria do marido e decide banhar-se de cócoras e com a "combinação de florinhas" propositadamente. Talvez Santanita tenha percebido que o marido a desprezava porque era uma mulher simples e, por esse motivo, ela comete o ato sabendo que ele ficaria envergonhado. Na verdade, acredita-se que possa ser um momento em que ela mostra um indício de consciência de si mesma, porque, ao perceber o desdém do marido, decide querer limpar de si tudo aquilo que a retraía e que a transformava numa mulher sem brilho. Parece que há, em Santanita, uma intenção de se recriar, se renovar, longe da repressão a que era submetida enquanto vivia junto com Sebastião. Sendo assim, a postura daquela mulher retraída e que seguia tudo o que lhe era imposto pelo marido, pode estar sofrendo modificações. Santanita desobedece às ordens de Sebastião quando vai ao hotel, e ainda o envergonha ao mostrar-se para os banhistas. Essas atitudes, pela maneira como a narrativa é conduzida, nos fazem acreditar que Santanita nunca tinha contrariado o marido anteriormente. Isso pode ser considerado um pequeno indício de conscientização.

Havia sinais de que já havia certa indiferença no tratamento que Sebastião oferecia a sua esposa. Quando Sebastião conheceu Miss Laura, o desprezo por Santanita se intensificou. Miss Laura "pertencia ao grupo das pessoas inegavelmente superiores. As que desejam os pássaros e consideram os homens livres e independentes." 223 Maravilhado com a presença da estrangeira, Sebastião compara Miss Laura e Santanita evidenciando que na "sua mulher legítima [...] nascera nos últimos tempos uma farripa de bigode negro" 224 e ela nem se importou. Mas, as verdadeiras senhoras "tiram aqueles cabelos com pauzinhos de cera derretida". ${ }^{225}$ Esse comentário fez com que Santanita ficasse ofendida, "pelo presente e pelo passado"226 e criasse contra Sebastião uma espécie de revolta que a fez tomar a atitude de se exibir nas ondas de combinação e florinhas, junto com os familiares, chamando atenção dos veraneantes. Por conta da rejeição que sofreu, parece que Santanita cria forças para retornar a Redonda e lá, talvez, por meio do resgate de suas raízes, consiga desenvolver uma consciência de si.

\footnotetext{
${ }^{223}$ JORGE, Lídia. O cais das merendas. Lisboa: Publicações Europa-América, 1989, p. 130.

${ }^{224}$ Ibidem, p. 129.

225 Ibidem, p. 129.

${ }^{226}$ Ibidem, p. 129.
} 
Vê-se, pelas personagens citadas, que, mesmo saindo de um contexto rural e instalando-se num contexto urbano, a mulher, de acordo com Bedasee 227 , "se situa na esfera do privado", entre o "ranger das agulhas tecendo as rendas"228, sendo habitante de um mundo doméstico e, consequentemente, mantendo certo distanciamento do mundo público. Parece que o privado está na essência da mulher. Mesmo quando tenta se habituar a outro contexto, a mulher encontra dificuldade.

Depois que saíram da Redonda e foram habitar a praia das Devícias, o cotidiano das personagens sofre uma alteração: começam a trabalhar num hotel (ambiente fechado e luxuoso) e não mais no campo; desenvolvem serviços mais leves que os que realizavam antes; mas, ainda assim, continuam exercendo funções domésticas, lavar, arrumar, sob a supervisão de uma figura masculina, Sebastião Guerreiro, o maitre do hotel. Ao terem contato com o público, com o externo, com um ambiente globalizado que destoa da sua realidade, as mulheres sentem-se perdidas.

Nota-se que, em $O$ cais das merendas, essa falta de norte não se processa somente com as mulheres; ocorre com os camponeses como um todo, mas acredita-se que, na mulher, isso causa um impacto maior, porque parece que há, ainda de acordo com Bedasee, uma generalização de traços "femininos" que fazem com que se verifique uma mesmice entre as mulheres e também atribui a ela um caráter de inferioridade em relação ao homem, por conta da ideologia patriarcal que tocou a muitas comunidades do planeta. Mas um ato de coragem toca Santanita quando decide que vai ficar na Redonda. Esse ato pode proporcionar a ela o encontro consigo mesma para, possivelmente, tentar sair dessa "zona de conforto".

Sabe-se que o caminho para a busca de uma consciência de si se dá a partir da relação com o outro; em se tratando do romance em questão, com a figura masculina. Nesse caso, é possível notar, pelas palavras de Bedasee ${ }^{229}$, que "as personagens femininas são todas um eu em contraponto com o outro homem". Há, em $O$ cais das merendas, algumas personagens masculinas que integram a narrativa e que merecem ser destacadas pelas relações de diferença que estabelecem com as personagens femininas.

\footnotetext{
227 BEDASEE, R. "Identidade e alteridade na literatura feminina." In: IV Congresso da ABRALIC. Literatura e diferença. De 31 de julho a 03 de agosto, 1994, p. 863-867.

${ }^{228}$ JORGE, Lídia. O cais das merendas. Lisboa: Publicações Europa-América, 1989, p. 70.

${ }^{229}$ BEDASEE, R. "Identidade e alteridade na literatura feminina.” In: IV Congresso da ABRALIC. Literatura e diferença. De 31 de julho a 03 de agosto, 1994, p. 865.
} 


\section{3 - Sebastião Guerreiro: a representação masculina}

Dentre as personagens masculinas do romance, Sebastião Guerreiro é o que mais se destaca. Comicamente apelidado por Sebastião Cagaça, Sebastião Guerreiro é o líder do grupo e é quem conduz o povo da Redonda até o Alguergue para trabalhar em serviços subalternos. Sebastião é rodeado pela presença feminina: a mãe Belisanda Maria, a filha Rosária e a esposa Santanita Trigal. Sebastião sempre foi visto pela mãe como um predestinado: "A largura dos costados de Sebastianito foi pensada por deus para um fim que está por descobrir" ${ }^{230}$.

Essa predestinação acaba se evidenciando quando Sebastião cria um rádio que passa a ser visto como algo extraordinário. Nasce, então, a importância dessa personagem que conduz as pessoas do vilarejo até a praia das Devícias. Sebastião pode ser considerado o eixo da narrativa porque é por meio dele que se dá a grande alteração vivida pela comunidade. A importância da personagem já se apresenta em seu próprio nome, pois Lídia parece fazer alusão ao grande rei Dom Sebastião e o sobrenome Guerreiro remete a uma pessoa audaz, forte, capaz de enfrentar grandes desafios.

Sebastião Guerreiro, de acordo com o ponto de vista de Orione, pode ser considerado "a representação paródica do Rei Dom Sebastião". ${ }^{231}$ Nesse sentido, Sebastião Guerreiro, ao promover o trânsito das personagens do interior da Redonda até a praia das Devícias, faz com que esse percurso assuma tom de odisseia às avessas, pois, ao contrário do herói épico que conduz seu povo a um destino promissor, Sebastião, ainda que tenha boas intenções, acaba por levá-lo a uma degradação. Guerreiro também estava seduzido por aquela espécie de terra prometida e parece ter sido atraído também pelo próprio nome Devícias, onde, de acordo com Seixo, "sintomaticamente, e a par da acepção etimológica que o aproxima pertinentemente de "divisas", se articulam elementos sêmicos como "vícios" e "delícias"". 232

Pelo que mostra a narrativa, Sebastião foi mesmo capaz de demonstrar-se corajoso, com seu ânimo belicoso (tentando absorver ao máximo a cultura estrangeira e ainda compartilhá-la com os aldeões). Por outro lado, foi apelidado pelos próprios

\footnotetext{
${ }^{230}$ JORGE, Lídia. O cais das merendas. Lisboa: Publicações Europa-América, 1989, p. 170.

${ }^{231}$ O mito de Dom Sebastião se tornou a partir do século XVI um dos mitos portugueses mais significativos, quando, após a derrota de Alcácer-Quibir (perda da autonomia política de Portugal), transformou-se no Desejado, no Rei Encoberto que voltará para instaurar o Quinto Império. In: ORIONE, Eduíno José de Macedo. O romance de Lídia Jorge: História, mito e paródia. Kalíope, São Paulo, ano 5, n. 10 , ago/dez. 2009, p. 80-90.

${ }^{232}$ SEIXO, Maria Alzira."[Recensão crítica a 'O Cais das Merendas', de Lídia Jorge]" / Maria Alzira Seixo. In: Revista Colóquio/Letras. Recensões Críticas, n. ${ }^{\circ}$ 75, Set. 1983, p. 98-100.
} 
camponeses de Sebastião Cagaça quando deixou vir à tona seu lado frágil, acabando por desvalorizar um pouco sua coragem. Isso ocorre quando descobre que seu envolvimento com Miss Laura não daria os frutos que imaginava.

Miss Laura parece representar, para Sebastião Guerreiro, o objeto de desejo: o inglês, a cultura, a civilidade, a viagem, "o verdadeiro manjar da vida". ${ }^{233}$ Por outras palavras, ela representa o diferente, o outro, e a construção da identidade implica sempre uma relação de diferença com o outro. Porém, para viver essa paixão, Sebastião pretende desprender-se das suas raízes, esquecendo-se

das feições de Belisanda Maria feita corcunda pela velhice, da existência dessa Santanita Trigal. [...] Dessas duas sobretudo, mas de um modo geral de todas as que tinha conhecido até a idade dos quarenta e quatro contados. Desembaraçar-se mesmo de Rosária que vinha sentar-se na areia com uma mercadoria dentro de um cesto, e tão embasbacada que parecia feita de parvoíce. ${ }^{234}$

Sebastião rompe categoricamente com o passado e com todas as mulheres da família quando conhece Miss Laura. Esse corte familiar parece ser a radicalização de uma ruptura exigida de todos aqueles que querem ingressar no novo contexto urbano onde se situa o hotel, o que pode equivaler, simbolicamente, ao esquecimento do Portugal antigo, incentivando a modernidade que o estrangeiro traz. Essa modernidade se apresenta nas "parties" e em tudo que é referido pelas personagens da narrativa e que remete à cultura alheia, como o cinema americano e as revistas estrangeiras.

Sebastião tinha o hábito de ler essas revistas. Eram, na maioria das vezes, revistas francesas, e o que chamava atenção do empregado do hotel eram a vestimenta e a silhueta das mulheres. Era um modelo de mulher preestabelecido, da mulher europeia urbana, "Usavam-se agora as pessoas muito magrinhas, como se alongadas por um pôr de sol tardio. Bastava ver as colecções elle-mode para se ter a certeza absoluta de que assim era."

Por conta do visual que as mulheres apresentavam nas revistas, Sebastião acaba se apaixonando por Miss Laura. É com ela, "que pertencia ao grupo das pessoas inegavelmente superiores", que Sebastianito se aperfeiçoa na arte sublime de amar. Assim, tudo que é estrangeiro deverá ser imitado servilmente. Sob o ponto de vista de Sebastião, o que fugisse àquele padrão de beleza feminina não lhe serviria mais. $O$ empregado do hotel estava iludido e acreditava que "tinha sido escolhido por aquela

\footnotetext{
${ }^{233}$ JORGE, Lídia. O cais das merendas. Lisboa: Publicações Europa-América, 1989, p. 208.

${ }^{234}$ Ibidem, p. 200.
} 
mulher cheirosa como uma flor de prado"235, por isso passa a rejeitar a todas as mulheres com que tinha contato.

Outra personagem masculina tomada pela solidariedade machista que parece concordar com o comportamento de Sebastião Guerreiro é Simão Rosendo, também empregado do hotel. Diz ele: "Rainhas, donzelas, belas teodoras. [...] Imitadoras das verdadeiras mulheres apenas pelo que lhes entra boca e sai por um sítio que eu cá sei, e que em frança se diz com um tom de mais. Tivessem aprendido com miss Laura. Era ou não era, Sebastianito?" ${ }^{236}$ Simão, assim como Sebastião, esperava que as mulheres da Redonda aprendessem com Miss Laura a se vestir e se comportar. Ele acreditava que esse comportamento fora dos padrões da modernidade contribuía para que as personagens começassem a ficar insatisfeitas com as "parties". De fato, Zulmirinha, a organizadora das "parties", passou a se sentir a "rainha das frustrações".

A felicidade de Sebastião em relação a Miss Laura logo é abalada e ele fica chateado com a partida sorrateira da estrangeira, pois "tinha-se-lhe enchido a vista de humidade ao falar a miss Laura da qualidade do amor português" ${ }^{237}$. Depois da partida de Miss Laura, "A pouco e pouco a tristeza de Sebastianito passou a Valentina e de Valentina passou [...] a Pinaira. Como se se transmitisse pela simples saudação da manhã." ${ }^{238} \mathrm{O}$ contágio também se estendeu a Simão Rosendo, "não tinha nem um bocadinho de esperança" 239

Embora o contato com miss Laura tenha trazido frustrações a Sebastião, por conta do discurso amoroso que parece ir às raízes culturais do ser português, o maitre do hotel parece ter criado uma nova versão ao seu discurso amoroso. A partida de miss Laura proporcionou a Sebastião a conscientização de que a história dos reis que matam a si mesmo e a sua amada e são sepultados juntos melancolicamente, já não se usa mais.

Parece que o imaginário português sortido pelas grandezas do passado e mitos que o rondam não se presta mais à constituição da identidade não somente de Sebastião, mas das personagens da narrativa como um todo. Linda Hutcheon ${ }^{240}$ observa que os conceitos "certeiros" herdados pelo humanismo liberal, como unidade, autoridade, totalização, centralidade, entre outros, caem por terra na literatura contemporânea de

\footnotetext{
${ }^{235}$ JORGE, Lídia. O cais das merendas. Lisboa; Publicações Europa-América, 1989, p. 200.

${ }^{236}$ Ibidem, p. 186.

${ }^{237}$ Ibidem, p. 216.

${ }^{238}$ Ibidem, p. 218.

${ }^{239}$ Ibidem, p. 237.

${ }^{240}$ HUTCHEON, Linda. Poética do pós-modernismo: história, teoria, ficção. Rio de Janeiro: Imago, 1991.
} 
traços pós-modernos. A identidade já não é mais construída pela homogeneidade prefigurada pelo conjunto de "sujeitos individuais fixos", mas "identidades contextualizadas", afirmadas e confirmadas por meio da diferença.

Sebastião Guerreiro parece caminhar para essa "identidade contextualizada" quando tem contato com miss Laura (na narrativa, ela é simbolizada como o outro, o estrangeiro, já anteriormente mencionado). A diferença cultural e social que se evidencia entre essas duas personagens proporciona a Sebastião Guerreiro o contato com o novo e, por extensão, esse contato se estende ao povo da Redonda, já que o maitre do hotel exerce o papel de guia dos camponeses. Evidentemente, o contato de Sebastião com Mr. Hals (personagem holandês), o gerente do hotel, Mr. Smollett ou Mr. Brown e dos camponeses da Redonda com a língua estrangeira, com o ambiente luxuoso onde se instala o Alguergue, contato com uma cultura adversa a eles, proporciona certa contextualização.

No interior da narrativa, o convívio entre as personagens (prioritariamente quando já estão habitando o espaço da praia das Devícias), especificamente das personagens femininas com as masculinas (em destaque Sebastião Guerreiro e Simão Rosendo), se mostra significativo para que se crie essa "identidade contextualizada". Isso se dá em primeira instância quando Sebastião apresenta o universo do hotel proporcionando o primeiro contato com um ambiente diferenciado. Depois quando Simão instrui aos aldeões para conseguirem uma ocupação no hotel. Essa experiência de trabalho é totalmente diferente em relação àquela que tinha quando moravam na zona rural, pois ao turismo devem eles uma vida aprazível, de trabalhos leves e delicados. Posteriormente, a crítica que Sebastião faz ao comportamento das mulheres da Redonda comparando-as com as mulheres das revistas estrangeiras e principalmente com miss Laura, causa nas camponesas certa chateação, mas as fazem perceber que viver o ambiente da praia das Devícias não era suficiente para a formação da consciência de si, seria necessário preservar as raízes, resgatar ao passado.

Percebe-se, em algumas personagens femininas, esse desejo de resgatar o passado, de tentar uma aproximação em relação àquilo que supostamente havia ficado esquecido, porém essa aproximação parece difícil. Ainda assim, nota-se que a proximidade que há entre o masculino e o feminino (mesmo apresentando divergências) pode contribuir para um inicio de conscientização de si, principalmente no que se refere a Rosária, ao meu ver a personagem mais significativa do romance. 


\section{4 - Rosária: o sentimento de "não-pertencer"}

Entre as personagens femininas, aquela que apresenta um nível de consciência mais elevado é Rosária, a filha de Sebastião Guerreiro. Apesar de "tão branca, tão de cera, tão magrinha" 241 e tão frágil, Rosária se mostra, no romance, como a representação do resgate de uma identidade perdida. Personagem emblemática em $O$ cais das merendas, Rosária acaba sendo, para as personagens da narrativa, um tormento para a consciência e também desperta neles um sentimento de culpa. Isso pode ser explicado pelo núcleo dramático do romance, que é o suicídio da moça. Tal acontecimento desperta em todos uma sensação traumatizante, capaz de despertar o desejo de enterrar o passado:

Uma vez que se enterrava as merendas não haveria razão para que não se enterrasse também a lembrança de Rosária, um pensamento íntimo que todos tínhamos, muito mudo e muito colectivo, com todas as coisas a passarem nesta vida. ${ }^{242}$

O episódio da morte da filha de Sebastião e Santanita parece o ponto crucial da obra, pois se configura como um sacrifício ritual que inaugura o processo da transformação comunitária. Sendo assim, acredita-se que o desaparecimento das tradições locais, dos hábitos linguísticos que se evidenciam nos aldeões não parece ser consequência de uma amnésia coletiva, mas sim de um esforço também coletivo para não recordarem o passado. Esse esforço se intensifica não somente porque a recordação é dolorosa, mas também porque constitui um obstáculo à imitação dos estrangeirismos, das maneiras civilizadas que o povo da Redonda tanto admirava.

De acordo com Orione ${ }^{243}$, o acontecimento da morte de Rosária "é retratado com imagens canibalescas, e configura-se como um ato de expiação, cujo efeito de sentido é a purgação da mancha comunitária". Pelo que parece, $O$ cais das merendas se mostra como uma paródia da encenação ritual do bode expiatório. Ainda como aponta Orione, a finalidade de sacrificar o bode expiatório nas comunidades primitivas era a de limpar um erro cometido pela coletividade imolando um de seus membros, por isso a penitência/castigo a que o grupo submetia um homem em particular não era vingança contra ele, mas purgação para o próprio grupo.

\footnotetext{
${ }^{241}$ JORGE, Lídia. O cais das merendas. Lisboa: Publicações Europa-América, 1989, p. 84.

${ }^{242}$ Ibidem.

${ }^{243}$ ORIONE, Eduíno José de Macedo. “O romance de Lídia Jorge: História, mito e paródia”. Kalíope, São Paulo, ano 5, n. 10, ago/dez. 2009, p. 85.
} 
É isso que aparece no romance de Lídia Jorge, porém de um forma parodiada, pois o fato de Rosária ter-se sacrificado (atirando-se do alto de um penhasco sobre a pedra alguergue, que deu nome ao Hotel Alguergue) não alivia a culpa dos aldeões; ao contrário, atormenta-os ainda mais. Isso mostra que a alusão constante a Rosária, sempre presente na memória de todos, aparece como um sentimento de culpa coletivo. A adoção de novos hábitos culturais acarreta, nos aldeões, um desmemoriamento brutal que ocasiona uma crise de identidade. Mesmo sob o efeito da falta de memória, para o povo da Redonda "a lembrança de Rosária continuava a ser a larvazinha na mansidão"244

A narrativa mostra essa crise de identidade se intensificando na personagem Rosária, razão pela qual ela comete suicídio. Num determinado momento do texto há uma divisão entre as personagens: aquelas que decidem permanecer na Redonda (pai Patroços, Santanita - mãe de Rosária) e aquelas que decidem experimentar uma aventura num ambiente urbano rompendo com o espaço rural e também com o passado (Sebastião Guerreiro e todos que o seguem). Entre esses dois mundos, o da modernidade almejada e o do passado, que deve ser esquecido, entre o "antigamente" e o "progresso", está Rosária: dividida entre, por um lado, permanecer ao lado da mãe na Redonda, e, por outro, ficar ao lado do pai Sebastião Guerreiro e dos deslumbramentos dele.

Rosária não habitou o Alguergue. Ela transitava entre o Alguergue e o sítio da Redonda, sem rumo, carregando um cesto. "O cesto costumava pô-lo ela diante das pernas, sentado quase sobre os pés e cobria-o com uma toalha de pano fino, como se aí estivesse qualquer coisa que dormisse." ${ }^{245}$ A menina carregava cuidadosamente aquele cesto como se tivesse o intuito de preservar o que ele continha. Ela carregava no cesto, cuidadosamente embalados em papel vegetal, uma espécie de bolinho polvilhado "de grão de açúcar [...] coalhado mas líquido, quase transparente, [...] promessa de salivação gostosa e doce. Dentro do cesto. E essas línguas de creme, Rosária dispunha-as todas do mesmo lado, saídas dos redondos. a qualidade do produto é que chamava." 246

Pela descrição, o que ele continha parecia ser realmente muito especial, "produto de qualidade". Por ser esse produto "uma promessa de salivação gostosa e doce" parece que traz bem-estar a quem degusta. Rosária caminhava com o cesto de um lado a outro,

\footnotetext{
${ }^{244}$ JORGE, Lídia. O cais das merendas. Lisboa: Publicações Europa-América, 1989, p. 130.

245 Ibidem, p. 139.

246 Ibidem, p. 140.
} 
como se guardasse ali dentro uma espécie de tesouro que deveria ser preservado. Talvez ela possa representar uma espécie de guardiã da identidade, que, simbolicamente, poderia estar contida naquele cesto. Tentava sim, a menina, preservar as raízes daquele povo.

Ao transitar de um espaço a outro, Rosária começa a perceber que aquele percurso não levaria a destino algum, pois os pensamentos vagos e as suas ausências estavam ficando cada vez mais frequentes:

E era assim. Rosária ficava a ver. E sentindo-se vestida e trajada daquele modo, ali sentada no meio da areia, fazia rolar grãozinhos mínimos por entre o papo dos dedos, e deveria sentir-se uma estátua de cão entre os humanos. Não, não era pelo desempenho daquela função. Era por parecer que entre as outras pessoas havia uma rede invisível que as unia em algum propósito comum, ali junto do mar. Menos ela. ${ }^{247}$

Há indícios de que não há conexão entre ela e as outras pessoas. Sente-se deslocada, imbuída de um sentimento de não-pertencer. Porém, às vezes ela não sabia o que sentia, "só que o mar lhe fazia uma dor de incômodo dentro do coração. Apetecialhe imenso largar o cesto e pôr-se a correr até uma rocha onde alguém lhe fechasse os olhos com um então boa noite." ${ }^{248}$ Vê-se, então, que Rosária não sabe que caminho e que destino tomar: daí a imensa angústia que terminará por levá-la ao suicídio. A indiferença que o pai manifestava por ela também a fazia sentir-se angustiada. Sebastião, só pensando em ostentar a identidade que escolhera para si em revistas estrangeiras, ignorava a menina. Quando o maitre do hotel não lhe era indiferente, queria que ela se transformasse em outra, de outra natureza.

Para comunicar-se com a mãe, nessas idas e vindas, Rosária escreve-lhe cartas:

Escrevo-lhe esta carta, minha mãe. E ele tinha-lhe dito no dia imediato a chegar, depois da conversa com o tal Augusto Folhas. Enquanto trabalhamos, Rosária, é como se não nos conhecêssemos, minha filha. [...] Eu, Sebastião Guerreiro, indo e vindo, e tu ficando e escondendo o dinheiro na carteira e no avental. [...] Eu indo e vindo. E tu nem olhando para mim a não sei de longe, e sem aceno nenhum. Assim, ao terceiro dia, Rosária só conhecia o seu pai, de resto ninguém. ${ }^{249}$

Respondendo às cartas de Rosária, a mãe, que nunca concordara com a ideia imposta por Sebastião, a de Rosária abandonar os estudos para vender doces na praia,

\footnotetext{
${ }^{247}$ JORGE, Lídia. O cais das merendas. Lisboa: Publicações Europa-América, 1989, p. 139-140.

248 Ibidem, p. 143.

249 Ibidem, p. 140-141.
} 
também passa a rejeitar a filha, impedindo que ela retorne a Redonda. Com essa notícia, o sentimento que toma conta de Rosária é de que ela já não pertence a ninguém nem a lugar nenhum.

Através da escrita, na carta que envia a sua mãe, Rosária encontra uma maneira de expressar o que sentia, a mais profunda solidão. Pelo que parece, sua voz, assim como a das mulheres da Redonda, sempre esteve silenciada por conta não somente do espaço que habitava anteriormente, ambiente rural em que o convívio com pessoas fora dali era praticamente inexistente, mas também pela condição de inferioridade em relação ao homem a quem se submetia. A escrita se mostra como uma forma de libertação, porque pelo que se acredita, o escrever não é apenas colocar palavras, que formem ou não sentido, no papel. A escrita proporciona a quem escreve um mergulho em si mesmo rumo ao autoconhecimento de sua essência.

É provável que o fato de Rosária escrever cartas à mãe tenha despertado nela a consciência de que naquele momento não havia lugar no mundo para si. Pelo que consta, a comodidade da Redonda (estagnação) não era viável porque essa estabilidade não proporcionaria a ela um conhecimento de si. Ao passo que as novidades da praia das Devícias também não eram interessantes porque, para viver aquele momento, teria que abandonar sua cultura e isso lhe seria muito prejudicial.

Para aumentar ainda mais a crise de identidade pela qual Rosária estava passando, a personagem Folhas (pintor e autoridade intelectual do hotel) decide pintar um retrato da menina. Nesse sentido, há um trecho significativo que demonstra a diferença de opinião entre Sebastião e Folhas acerca da menina, pois cada um deles a vê de uma forma. Para o pintor, "Rosária parecia outra realidade. Era uma figura de brueghel, o velho, transportada da antiga Antuérpia para a Praia das Devícias" ${ }^{250}$. Folhas explica: "brueghel senhores, gostava de pintar os feios os desditosos, afetando-os ainda mais por suas mãos" ${ }^{251}$ A visão do pintor se opõe àquela apresentada pelo pai da menina, acreditando "que talvez pareça a minha filha com nathalie wood, a que fez o esplendor na relva, coitadinha" 252 Entre as duas imagens que descrevem a jovem, a primeira que a vê como uma figura deformada de Brueghel e a segunda, que a considera uma estrela de cinema, a identidade de Rosária se perde.

\footnotetext{
${ }^{250}$ JORGE, Lídia. O cais das merendas. Lisboa: Publicações Europa-América, 1989, p. 131.

251 Ibidem, p. 131.

252 Ibidem, p. 131.
} 
Houve um momento na narrativa em que Rosária esteve "tão contente"253 e tenta demonstrar essa felicidade por meio de uma carta que escreve à mãe. Estava trabalhando no hotel e, pelo seu bom desempenho, recebe uma recompensa, "Laura, muito boa, começou por lhe dar logo um vestido comprido e branco que Rosária ensaiou à pressa diante de um espelho" ${ }^{254}$. Rosária gostava de Miss Laura, de arrumar os quartos, mas "sentia saudades de ver o cão correr, as idas e as vindas das pessoas." ${ }^{255}$ Ao que parece, apetecia a Rosária lembrar suas raízes.

Escrevia, a moça, também para seu padrinho, "só quando se escolhe a madrugada, meu padrinho, é que se cresce, sinal de que se tem dentro de si o milagre do sentimento [...] Estou a escrever-lhe esta carta e não sei como vou acabar de tão contente eu ando." 256 Toda expressão de sentimento demonstrada por Rosária se externava por meio da escrita. Para contribuir com a felicidade da menina, as palavras de Folhas a deixaram mais animada:

Deixaste de ser uma padeira de brueghel para seres uma figura da renascença, $[\ldots]$ Rosária também ria pela ideia. [...] era assim que ele a retinha. [...] Grande rainha, dona dos mares, das ilhas, das correntes, das cosas e enseadas e também das nuvens. Eu? Sim, tu. Ainda ninguém mandou pôr nada em teu nome, mas já é tudo como se fosse teu. ${ }^{257}$

As palavras do pintor parecem deixar entrever que o fato de Rosária transitar entre os dois espaços, Redonda e Devícias, a fazia diferente dos outros. Talvez ele a considerasse com uma visão diferenciada, que parecia ir além do deslumbramento com o estrangeiro e da estagnação instalada no espaço rural do sítio. $\mathrm{O}$ fato de a personagem exercitar a escrita (mergulhar em si mesma) também amplia sua visão sobre si e, consequentemente, sobre o mundo e isso pode favorecer uma possível construção de identidade, o que, para os aldeões, torna-se mais difícil.

Folhas, durante sete dias, pinta Rosária e, quando ela se vê no retrato, entra em choque, pois

não se reconhece num único traço da pintura feita com a claraboia toda descoberta estando ela em vestido branco. O Folhas pô-la riscas e o rosto, ou no seu lugar, era uma só nodoa de vermelho encarnado vivo. Ela disse. Olha uma árvore em vez de mim. [...] Rosária a partir

\footnotetext{
${ }^{253}$ JORGE, Lídia. O cais das merendas. Lisboa: Publicações Europa-América, 1989, p. 194.

${ }^{254}$ Ibidem, p. 194.

${ }^{255}$ Ibidem, p. 201.

${ }^{256}$ Ibidem, p. 204.

${ }^{257}$ Ibidem, p. 204.
} 
daí não voltou a sair de madrugada. Acordava sem despertador, mexia-se, remexia-se, e estava tão ressentida... ${ }^{258}$

A jovem ficou realmente muito decepcionada porque não se enxergava diferente. Ao que parece, ela esperava que viesse um retrato de uma mulher comum, assim como as outras. É bem provável, pelo comportamento de Rosária diante da sua imagem pintada por Folhas, que nem ela tinha consciência de sua verdadeira imagem, do quão era diferente. Somente Folhas, com seu olhar de artista, foi capaz de perceber essa diferença.

Atormentada pela crise de identidade, fruto de todos os fatores que já foram elencados, indecisão entre os espaços da Redonda e das Devícias; o passado e o presente; seu modo de vida e sua origem; a rejeição dos pais; e, sobretudo a imagem monstruosa que a pintura/espelho representa dela - Rosária acaba por matar-se.

Mesmo após sua morte, Rosária era a todo momento mencionada e lembrada por todos. O povo, liderado por Sebastião, queria esquecê-la, passando a viver intensamente o universo das "parties", sem trazerem à tona nenhum resquício do passado. Mas, concomitantemente a isso, lembravam que havia a presença de Rosária ali e isso tornava aquele passado cada vez mais presente. Afinal, os aldeões estavam tentando esquecer as "merendas" pelo sofrimento que aquela época causara, mas a lembrança estava sempre ali, mostrada pela presença da moça, e seria impossível deixar para trás todo o passado, sem ao menos mencioná-lo. Sendo assim, a imagem da jovem permanece na memória das personagens e, com isso, a culpa coletiva não é extirpada, mas sim agravada.

Com o passar do tempo, a negação da própria identidade acarretou um distanciamento entre as pessoas: "pareciam desligadas umas das outras, era como se não houvesse famílias, e constituíssem bandos,..." ${ }^{, 259}$ O que se evidencia também é um esquecimento acentuado: "estávamos todos desmemoriados sem sabermos, por exemplo, se as segas se faziam na primavera se no outono." ${ }^{260}$ Isso mostra que a identidade dos aldeões está-se perdendo em meio à tristeza e à solidão. A consciência de si acaba ficando enclausurada em obsessões marcadas pela artificialidade, vulgaridade, pobreza e ignorância.

Pelo que se vê, as personagens femininas apresentam, por todos os elementos que já foram destacados, um grau de consciência ainda mais precário que o dos homens.

\footnotetext{
${ }^{258}$ JORGE, Lídia. O cais das merendas. Lisboa: Publicações Europa-América, 1989, p. 206.

${ }^{259}$ Ibidem, p. 144.

${ }^{260}$ Ibidem, p. 244.
} 
Com isso acabam, essas mulheres, se perdendo em meio às transformações decorrentes do processo de globalização, por exemplo.

Além disso, o tempo parado e guiado pelas estações do ano, pode contribuir para a estagnação das personagens: "pensamentos tristes [...] e tudo a correr tão lento, o verão em vez de chegar, antes a fugir do calendário com o acinte das coisas que se fazem esperar." 261 O passar dos dias é tão lento que nada parece avançar. Não há sinal de progresso, nem diante do convívio com os estrangeiros. Continuam regidos pelo tempo da natureza mesmo habitando o hotel. É possível que isso ocorra pelo fato de não haver uma transformação interna; os camponeses conhecem um espaço que se pretende globalizado (onde se situa o hotel Alguergue), porém o comportamento deles continua atrelado à vivência daquele tempo mítico, estático, regido pela natureza.

Esse tipo de tempo remete à espera, que é tão incessante, tão longa que os camponeses já nem se dão conta do tempo que passa. Isso pode ser notado quando já não havia mais nenhum estrangeiro no hotel e os aldeões permanecem ali aguardando a chegada dos holandeses. A espera foi tão demasiadamente extensa que

Não é que os paus secos tinham rebentado em renovos e guias às suas costas? Desabrochando folhas e flores? Puro pessegueiro florido, com pétalas brancas e rosadas de primavera? Disseram depois quando transpuseram o átrio do Alguergue iluminado pela espera que se vivia $^{262}$

Para eles, aquele era um fenômeno que deveria ser explicado, por isso ficam "em estado de choque, com a língua atracalhada entre os dentes" porque "ainda não percebemos o significado. [...] Já era 16 de agosto desse ano, mas continuava a ser $15^{, 263}$

Os fragmentos mostram que o tempo se apresenta paralisado, e essa ociosidade que a estagnação promove pode fazer virem à tona os dramas mais íntimos, principalmente, das personagens femininas. A narrativa mostra Valentina Palas perseguida por fantasmagóricas imagens de comidas; Aldegundes Beira, que perde a memória de tudo; Pinaira, armando intrigas contra Sebastião e Miss Laura; enfim, há uma tendência à não conscientização de si por parte das personagens, e o tempo parece contribuir significativamente para isso.

\footnotetext{
${ }^{261}$ JORGE, Lídia. O cais das merendas. Lisboa: Publicações Europa-América, 1989, p. 215.

262 Ibidem, p. 221.

263 Ibidem, p. 221.
} 
Assim como o tempo, o espaço também parece não colaborar para a construção da identidade feminina. A Redonda, pela descrição que se nota no romance, se classifica como um espaço alienante, pois especificamente as mulheres voltavam sua atenção aos trabalhos domésticos e rurais. Além disso, enquanto habitavam o sítio não tinham contato com o exterior e isso vale para toda a comunidade, não somente para as mulheres. Quando vão para o Alguergue, guiadas por Sebastião, a situação não muda. Mesmo tendo contato com uma cultura diferente e com um ambiente luxuoso, continuavam exercendo trabalhos domésticos, evidentemente menos pesados, mas eram domésticos.

Esses dois espaços não se mostram favoráveis a que ocorra um reconhecimento de si, pois, pelo que se nota, as personagens sentem-se oprimidas e mostram-se influenciadas pelo tratamento que recebem dos personagens masculinos. São colocadas numa posição de inferioridade perante os homens, quando habitavam os dois espaços; e comparadas às mulheres de revistas estrangeiras e a Miss Laura, quando habitavam o espaço do Alguergue. São, constantemente, submetidas a certa humilhação que não as faz progredir, mas sim, cada vez com mais intensidade, fecharem-se em si mesmas.

A exceção está em Rosária, que, mesmo estando inserida nesse tempo e espaço, sofrendo, assim como as outras personagens femininas, influências que dificultam a conscientização de si mesma, consegue ter uma noção de que o ideal seria agregar o presente ao passado, sem se desvencilhar do passado. Talvez num primeiro momento retornar às raízes para conhecer a si mesma e, quem sabe, adentrar o processo de construção da identidade. Rosária não resiste à pressão, como já foi dito, e não somente entra em crise, como também se suicida. Mas houve uma tentativa e essa semente foi disseminada e ficaria na memória dos camponeses.

O último episódio do romance, intitulado Nocturna (última party que serviria para alegrá-los), mostra que foram acometidos por uma mesmice, uma falta de ocupação que os fazia "limpar o que está limpo". ${ }^{264}$ Relembrar, então, as merendas que eram difíceis, mas eram feitas para vencer, era a única saída; já as "parties” eram monótonas e com muitos bocejos. A nocturna foi realizada no escuro. Essa escuridão simbólica que Lídia Jorge propõe pode remeter a um esvaziamento da cultura dos aldeões ao entrarem em contato com o estrangeiro com o intuito de não preservação da própria cultura. Seria necessário que os aldeões revissem criticamente o passado, para não mergulharem numa

${ }^{264}$ JORGE, Lídia. O cais das merendas. Lisboa: Publicações Europa-América, 1989, p. 231. 
espera alienante; e verificar as mazelas do presente para tentar modificá-las. Acredita-se que somente assim seria possível a construção de uma identidade.

De acordo com as palavras de Bulger, "O isolamento cultural de $O$ dia dos prodígios é, afinal, tão pernicioso no que respeita ao desenvolvimento e ao progresso como o pseudo-cosmopolitismo de $O$ cais das merendas. ${ }^{265}$ Há, de fato, semelhança entre as obras quando Lidia Jorge apresenta duas comunidades rurais que vivem isoladas em seu universo particular: a primeira, de $O$ dia dos prodígios recebe influências externas, ou seja, as notícias do mundo exterior adentram o vilarejo de Vilamaninhos por meio dos soldados, ao passo que, em $O$ cais das merendas, os habitantes da Redonda vão ao encontro do progresso. Os camponeses dos dois romances não obtêm sucesso, pois não conseguem adaptar-se ao novo e isso os faz continuar no marasmo, na mesmice.

Ainda assim, acredita-se que Lídia Jorge procure mostrar, por meio das personagens Branca Volante, de $O$ dia dos prodígios, e Rosária, de $O$ cais das merendas, que ainda pode haver um fio de esperança para a construção da identidade feminina. Em meio à quase total alienação em que vivem as personagens do primeiro romance da autora e à aculturação forçada do povo da Redonda, no segundo romance, que não passava de uma ilusão de civilização e transformação, estão Branca e Rosária para mostrar que ainda há possibilidade de mudança.

Verificou-se que o nível de consciência de Branca Volante está pouco mais desenvolvido se comparado as outras personagens do romance, mas ainda possui muitos traços de primitivismo. Já Rosária demonstra um grau de conscientização pouco mais elevado em relação ao de Branca, porque sai de seu espaço de origem e transita para outros espaços: o trajeto do sítio ao Alguergue (por diversas vezes) e no hotel. Isso mostra que Rosária tem uma vivência externa, ao passo que Branca jamais havia saído de Vilamaninhos. Mesmo transitando de um local a outro, Rosária não suportou a pressão e tirou a própria vida. A atitude da personagem demonstra que o processo de construção identitária, principalmente para as mulheres, tem muitos complicadores.

Lídia Jorge deixa transparecer, nos dois primeiros romances, que o mecanismo de "vir a ser", de criar-se a si mesmo, é árduo, mas, ainda com todas as dificuldades que aparecem no meio do caminho, é possível, mesmo que muito gradativamente,

\footnotetext{
${ }^{265}$ BULGER, Laura. "«O Cais das Merendas» de Lídia Jorge: uma identidade cultural perdida?". In: Revista Colóquio/Letras. Ensaio, n. ${ }^{\circ}$ 82, Nov. 1984, p. 51-57, p. 56.
} 
ultrapassar barreiras e seguir rumo ao conhecimento de seu eu interior, para que a essência de cada ser não seja negada (especificamente do ser feminino). Essa pretensão da autora parece ser pertinente às suas obras e essa questão será também tratada em seu terceiro romance, Notícia da cidade silvestre. 
CAPÍTULO III

A PERMANÊNCIA NA IMPERMANÊNCIA: A CONSTRUÇÃO DA IDENTIDADE FEMININA EM NOTÍCIA DA CIDADE SILVESTRE 
Da leitura de Notícia da cidade silvestre, pode-se perceber, diferentemente do que se constatou ao estudar as personagens femininas destacadas nos dois romances anteriores, a permanência das personagens femininas num ambiente urbano. A ação se passa em Lisboa, particularmente entre as freguesias de Belém (onde ficava o atelier de David Grei, para onde Júlia e Joia se mudam depois da morte dele) e São Mamede, lugar um pouco melhor, onde Júlia consegue alugar uma casa com quartos que ela subloca para completar a renda.

Outros bairros e ambientes permeiam as confissões que Júlia faz à sua interlocutora (desconhecida do leitor), compondo um retrato de Lisboa no período pósrevolucionário. Há, por exemplo, a referência ao Café Tofa, um dos mais concorridos de Lisboa, aonde Júlia e Anabela vão tomar um romântico café e onde Anabela lhe entrega uma declaração de amor - junto com um presente, que é o Carmina Burana; há o João Sebastião Bar, para onde Celina quer levar Artur no dia em que ele põe fogo às roupas, bar que, de fato, foi o preferido dos intelectuais da esquerda no período entre 60 e 80; há a Avenida de Roma, onde moram os burgueses; há o Casal Ventoso, lugar das prostitutas e dos drogados etc. Enfim, o ambiente retratado nesta obra de Lídia Jorge é o de Lisboa/Portugal e sua degradação sociocultural, que também estaria passando por um processo de reconstituição de identidade.

Referência espacial também importante é o Tejo: esse rio é um dos grandes objetos de contemplação de Júlia; além disso, alegoriza a máxima heraclitiana de que tudo flui (Panta Rei) e funciona como espelho em que a protagonista, em sua fase de amor por Artur Salema, projeta suas emoções. Essa mudança de espaço, já que em $O$ dia dos prodígios e $O$ cais das merendas tratava-se de um espaço rural, acaba contribuindo para um comportamento um pouco diferente das personagens de Notícia da cidade silvestre em relação ao das personagens dos romances anteriores.

Quanto à categoria temporal, existem vários elementos que, ao longo das confissões de Júlia, vão delineando os traços éticos, estéticos, culturais e ideológicos do período abarcado pela narrativa, cujos episódios se passam entre o fim da década de 60 e o final da década de 70. A estação espacial norte-americana Skylab, que se desintegra no espaço em 1979, assinala, por exemplo, o final da narrativa, a época em que a vida parece querer assumir um colorido mais vivo e bonito para Júlia, João Mário, o cachorro, Fernando Rita e o carro Zephyr. A repressão do final da década de 60 é referida por Júlia, embora ela confesse sua alienação em relação aos problemas dessa 
época: “Ora nessa altura estávamos em sessenta e sete e por isso falava-se baixo com receio que as paredes ouvissem, o estuque gravasse." 266.

O período de setenta e quatro aparece, no relato analéptico de Júlia, ligado à euforia de David Grei com o movimento revolucionário e a sua intenção de assumir sua posição revolucionária por meio da estatuária (Júlia, por exemplo, era o modelo da alegoria da Liberdade que David estava esculpindo e que acabou por ficar inacabada). Outras marcas temporais são, de um lado, o filósofo Marcuse, Bob Dylan, Rolling Stones, a roupa hippie de Ida, a companheira de Contreiras; de outro, o João Sebastião Bar, frequentado pela elite intelectual de algum poder aquisitivo e até o cigarro Eva, com florzinhas no filtro, preferido pelas moças burguesas, para quem o fumo era mais um índice de elegância, glamour e liberação do que propriamente um vício.

Há, ainda, referências importantes sobre a categoria espaço-temporal, relacionadas ao período em que ocorrem os episódios relatados por Júlia: a narrativa se abre no Natal, um Natal que evoca a Páscoa, ambas as datas nuclearmente importantes dentro da simbologia cristã, e que, simbolicamente, parecem anunciar, neste caso, o percurso de paixão, morte e renascimento de Júlia. Daí a identificação que a autora, indiretamente, faz entre a história de Júlia e uma parábola. Nesse mesmo sentido, em certos momentos aparecem referências pontuais ao "Gólgota" (na obra de Lídia Jorge, em minúscula, como substantivo comum, sugerindo a existência de vários lugares de crucificação), ao "monte das Oliveiras" (lugar da ascensão de Jesus ao céu ${ }^{267}$ e onde se acredita que fosse ocorrer a sua volta ${ }^{268}$, mas, em Notícia da cidade silvestre, a referência é ao pé das oliveiras. Em síntese, a sugestão é de que o percurso de construção da identidade de Júlia/do povo português também pode ser visto como um percurso envolvendo um sofrimento que tem muito de sacralizado.

No trecho seguinte, é possível notar o tom de tristeza e melancolia que emana das considerações que Júlia faz sobre a época (evidentemente que parte desse tom provém da voz do autor-criador e de sua atitude solidária com a protagonista):

Estávamos em setenta e seis, suponho, ainda um barulho real no ar, mas descontando o ruído que murchava, tudo corria manso. Manso o sol, manso o rio, manso o vento, e até o burburinho das reivindicações que passavam pelas ruas e onde me integrava pelas tardes, mesmo quando anunciadas com estrépito e gritadas com raiva, era monótono,

\footnotetext{
266 JORGE, Lídia. Notícia da cidade silvestre. 2. ed. Lisboa: Europa-América, 1984, p. 91.

${ }^{267}$ Lucas, 24:50-51 In: Bíblia Sagrada.

${ }^{268}$ Atos, 1:11: Zacarias, 4:14 In: Bíblia Sagrada.
} 
sem inventiva, igual aos do princípio do século, e acabei por desejar várias quadrigas combinadas atravessando os largos de Lisboa à hora do almoço, levantando poeira como nos circos para que toda a gente fugisse rápido, levando as criancinhas no ar. Pensava isso no meio da multidão. Mas não me lembrava do nome dos objectos que serviam para fustigar cavalos e perguntei ao Sr. Assumpção. "Chicotes" disse ele. "Diga-me o que quer fustigar". ${ }^{269}$

Esse trecho, embora longo, mostra algumas características da personagem Júlia e ainda o contexto em que essa personagem está inserida. Por exemplo, é possível verificar que a consciência da protagonista se apresenta num nível relativamente rudimentar, pois sua apreensão do real se dá por analogias ("levantando poeira como nos circos"; "levando as criancinhas no ar"), como se, a partir da sua visão, todo o mundo virasse uma grande mágica; por imagens e sinestesias. Além disso, a sua dificuldade em nomear certos objetos, como o "chicote", por exemplo, traduz a sua dificuldade em lidar com conceitos.

Simultaneamente, esse seu modo intuitivo de perceber o real revela ao leitor como está Portugal no período que sucedeu à Revolução dos Cravos. Aos sentidos de Júlia, tudo é "manso", "monótono", "sem inventiva", isto é, sem vislumbres de criatividade e novidade. Parece, no entanto, que, junto à sensação de Júlia, vê-se a voz do autor-criador, que também revela certo desapontamento com o decorrer dos acontecimentos posteriores à tão esperada liberdade que a Revolução dos Cravos anunciara.

$\mathrm{Na}$ verdade, no contexto da narrativa, esse tão ansiado momento de libertação, sinaliza ter gerado, acima de tudo, calmaria, frustrações e certo desnorteamento por parte de várias comunidades, entre elas as dos artistas. Este grupo aparece bem representado em Notícia da cidade silvestre. David, o marido de Júlia, é um escultor cuja vida acaba em suposto suicídio; Artur e Fernando, respectivamente amante e amigo de Júlia, também são inicialmente escultores; no desenrolar da ação, só Fernando persistirá nesse caminho; Artur voltará à vida burguesa, da qual, na verdade, nunca havia saído totalmente. O Sr. Assumpção, dono da livraria em que Júlia trabalha, é também um apaixonado por livros. Entretanto, chama a atenção o fato de que todos esses personagens sobrevivem no mundo da arte graças ao sonho, mas este não perdura.

A limitação da consciência da personagem Júlia se traduz também pelo discurso pautado pela dúvida, pela incerteza, pela insegurança. Essa insegurança de Júlia se

\footnotetext{
${ }^{269}$ JORGE, Lídia. Notícia da cidade silvestre. 2. ed. Lisboa: Europa-América, 1984, p. 62.
} 
manifesta por meio de uma linguagem inicialmente pouco assertiva, marcada por verbos dubitativos como crer, supor, advérbios de dúvida e outros ("Creio que éramos felizes")

Além disso, o constante contraste com a figura de Anabela acentuará esse dado da insegurança de Júlia. Desde o instante em que a havia conhecido, no escritório do advogado Atouguia Ferraz, se encantara com sua maneira de datilografar, cujo automatismo, aos seus olhos, era identificado à segurança:

Debaixo dos dedos dela as teclas grossas faziam um som de uma charrua. A alça da máquina para trás, para trás. A certa altura, entre campainhadelas, a secretária levantou os olhos e fixou-os em mim, mas continuou dactilografando. Assim sentada tinha um ar de prolongamento de máquina, tão serena e segura que se diria de metal também, e lembro-me de ter pensado que não sabia se quem escrevia era ela na máquina se a máquina nela.

[...] Invejo-te - gostaria que alguma coisa me ocorresse maquinalmente debaixo dos dedos, cheia de paz no meio dum vestíbulo. ${ }^{270}$

Outro traço marcante da sua alienação, de sua debilidade identitária, reside na excessiva dificuldade em se posicionar como sujeito responsável pelos seus atos. Um exemplo dessa fragilidade diz respeito ao modo como se deu o primeiro contato íntimo entre ela e David Grei, na ocasião em que ambos estavam na excursão da escola, ela como aluna e ele como professor, e ao modo como Júlia delega a outros a responsabilidade de impedi-la de se envolver naquela situação amorosa:

Tudo estava bem, já se regressava, mas uma seara amarela com as espigas viradas para o poente estendia-se para o mar. À beira dessa seara, que como um mar fazia ondas, havia um cadabulho estreito cheio de ervas e papoilas altas. O cadabulho era estreito e parecia perder-se na campina donde não se avistava uma única casa. Só um molho de freixos no meio, unidos como náufragos.

Venham, venham! Pareciam dizer os braços desses freixos vistos de longe. ${ }^{271}$

Se a natureza a convida à entrega, é dos colegas e dos demais participantes da excursão que ela espera a salvação, ou seja, os limites que a fariam retroceder e evitar aquele momento amoroso:

\footnotetext{
${ }^{270}$ JORGE, Lídia. Notícia da cidade silvestre. 2. ed. Lisboa: Publicações Europa-América, 1984, p. 4849.

${ }^{271}$ Ibidem, p. 89.
} 
Por que ninguém chamava, ninguém dizia - "Mestre, Mestre, venha cá! Fique na fotografia com os Rolling Stones." Ninguém dizia. Eram irresistíveis aquelas ondas de trigo ondulante, sabendo que atrás de nós ficavam os olhos daqueles que iam dizer que nos tínhamos afogado. ${ }^{272}$

Também quanto ao nascimento de Joia, não é Júlia que deseja um filho. Ao contrário, é David, que, nessa ocasião, não é ainda marido dela, quem lhe comunica que quer um filho. Ela lhe obedece, simplesmente. E então nasce Joia/João Mário, como um objeto estético produzido pelo pai:

"Quero um filho" - disse ele quando fomos passar as férias na Foz do Arelho. Passados meses, Jóia surgiu numa manhã, com o cabelo escuro, anelado, como uma criança grega escrita no bojo duma ânfora. Jóia era uma espécie de futuro para David Grei. ${ }^{273}$

Observa-se, nesse fragmento, que, para Júlia, o filho "surge", não nasce. E detalhe importante - Joia é uma espécie de futuro para David, não para David e Júlia. Ao relatar esse episódio, Júlia parece não se situar como participante dele; é como se narrasse algo que não lhe dissesse respeito. É com esse dado em mãos que o leitor pode interpretar o período entre trinta e um de março e dois de maio (talvez de 1979) como um período de renascimento; um período em que Júlia parece assumir, de fato, sua identidade como mãe. E importa notar que esse período de "gestação" da identidade materna não se inicia pontualmente no dia do envenenamento de Joia, mas vem de antes e envolve a interação com outras crianças, como Vítor Selim, o moleque de rua sem pais que o cuidem e o eduquem; como o irmão Porquinho (Paulo, o amigo, que descarrega na comida sua carga de ansiedade) e Cila, filhos de um casal separado (que, por sua vez, traz, na sua relação, alguns dos possíveis efeitos (maléficos) do novo tirano (o capitalismo da economia global) sobre as famílias burguesas). A pequena Cila, sempre querendo passar o batom de Júlia, também colabora indiretamente para a constituição da identidade de Júlia, como mãe e como mulher.

O problema identitário de Júlia nessa fase da sua vida, logo depois da morte de David Grei e antes de se estabilizar sua relação amorosa com Artur Salema, também pode ser visualizado por meio da sua identificação com certos bichos, como a galinha, o hipopótamo, ou as aves.

\footnotetext{
${ }^{272}$ JORGE, Lídia. Notícia da cidade silvestre. 2. ed. Lisboa: Publicações Europa-América, 1984, p. 89.

${ }^{273}$ Ibidem, p. 89.
} 
Por exemplo, antes de ir ao escritório do advogado Atouguia Ferraz para reivindicar o seguro pela morte do marido, Mão Dianjo "insistia comigo ainda aparvalhada, com o pescoço leve como uma galinha que apanhou pancada no poleiro e não sabe donde lhe caiu". 274

No Zoológico, depois de ter reconsiderado sua situação com Artur Salema e ter decidido "desapaixonar-se" (por influência das manipulações de Anabela), ela vai com Joia até a jaula do hipopótamo, que sempre lhe desagradara profundamente, e tem com o bicho um instante de penosa identificação:

Tinha prometido a mim mesma ignorar o relógio e dava uma volta e outra até mostrar pela vigésima vez a lodosa boca do hipopótamo. Era hábito de Jóia ficar fascinado por esse horrível bicho e costumava desviá-lo para junto dos PÁSSAROS que me pareciam bichos mais conformes à natureza humana, mas esse dia era especial e sentia-me tão amarrotada que resolvi deixar Joia sentar-se no antemuro. As badanas esponjosas do bicho entrando e saindo para dentro da boca pareciam-me um erro, ou tudo tinha sido feito por acaso e estávamos sós. Eu própria me sentia tão longe da perfeição quanto o hipopótamo.

Conforme atestam as teorias sobre identidade, o processo de conquista de identidade (não só de gênero) de Júlia se dá no contato social, implicando sempre que semelhante contato se dá com o diferente; no caso específico de Júlia, esse contato é focalizado a partir da sua união com David Grei e sua consequente ligação com Mão Dianjo, personagem dotada de personalidade forte e notória ascendência sobre as pessoas ao seu redor (particularmente sobre Júlia, de quem mais tarde virá a ser amante); com Anabela Dias Cravo, outra figura com enorme influência sobre ela; com o dono da livraria em que passou a trabalhar também por indicação de Anabela, o Sr. Assumpção (outro amante de Júlia); com Artur Salema, o segundo grande amor de sua vida, e seu grupo de amigos (que personificam, no romance, os ideais e a ideologia revolucionários que vigoraram no Ocidente desde os finais da década de 60); com outras mulheres, burguesas (como Celina) e não burguesas (como a hippie Ida, como Idalina, a companheira de trabalho na livraria, como Madalena (mulher de Mão Dianjo) e, enfim, como a esposa do "Padrinho" de Anabela - estas duas fazendo parte da galeria de mulheres que aceitam como legítima (ou mesmo justificável) a liberdade (exclusivamente) masculina de cometer adultério. Esse contraste entre os direitos

\footnotetext{
${ }^{274}$ JORGE, Lídia. Notícia da cidade silvestre. 2. ed. Lisboa: Publicações Europa-América, 1984, p. 48.

${ }^{275}$ Ibidem, p. 55.
} 
masculino e feminino é evidenciado no episódio decisivo da relação entre Júlia e Mão Dianjo (então amante de Júlia), quando, enfurecido por tê-la visto com outro, leva-a para um quarto sórdido "no pior bairro da Baixa". Essa atitude e o tratamento rebaixador de Mão Dianjo (ferido nos seus brios de homem que pode trair, mas não ser traído) contrapõem-se ao primeiro gesto efetivamente consciente e deliberado de Júlia, o de lançar a faca certeiramente na direção do amante, porém cuidando para não o ferir (era uma faca de cortar pão, com a qual não pretendia ferir ninguém).

O resultado dessa atitude foi quase que extático. O medo que viu na expressão de Mão Dianjo despertou nela a consciência de seu poder, de sua força, de sua existência. Na verdade, fora o próprio Mão Dianjo que, indiretamente, a orientara no sentido de encontrar-se a si própria. Numa das vezes em que ele estivera com Júlia e ela lhe confiara os problemas de Joia na escola, ele lhe dissera que o caminho para Joia resolver seus problemas passava pela aprendizagem do ódio, que Júlia tinha que ensinálo a odiar. Ainda exercendo involuntariamente esse papel de orientador e crítico, num outro episódio Mão Dianjo censura Júlia pela sua ausência, pelo seu não pertencimento, pela sua ausência de integração na sua classe. Mas, na verdade, ao final da narrativa, o leitor verá que o discurso de Mão Dianjo, assim como o de muitas outras personagens masculinas, não passa de um discurso vazio, que não é respaldado pela prática.

É provável que o sonho referido anteriormente não perdure porque a autora (entenda-se aqui autor segundo a concepção de Bakhtin) propõe um texto marcado pelo signo da mudança. Esse aspecto caracteriza-se por um conjunto de elementos significativos que se combinam para produzir a história. Já nas primeiras linhas do romance, a narrativa se inicia sob a inspiração de uma expressão clássica panta rei, pressupondo que os acontecimentos surgem da noção de que tudo é móvel, transitório, passageiro:

Espantoso como a vida corria, os jornais eram outros e as pessoas mudavam. Mesmo as que já não engordavam nem cresciam, compravam roupas, cortava o cabelo e de repente apreciam mudadas à janela dum outro carro. Quando a certa altura começou a pensar que afinal nenhuma metafísica se desprendia dos acontecimentos, pôs-se à beira do rio, um barco branco passou trambolhocando água abaixo, [...] Tinha tempo de copiar esses greguiformes na bainha da saia para perguntar ao Sr. Assumpção, e ele disse-lhe, sonhador, diante duma estante - "Panta rei? Tudo muda.". ${ }^{276}$

${ }^{276}$ JORGE, Lídia. Notícia da cidade silvestre. 2. ed. Lisboa: Publicações Europa-América, 1984, p. 15. 
Essa transitoriedade presente na obra remete à percepção de que as ações das personagens estão impregnadas do signo da mudança, ou seja, as atitudes mudam, as ideias se transformam, tudo muda. Essa mudança se mostra impulsionada pelo contexto em que se desenvolve o romance. Sabe-se que se trata de um período conturbado para a sociedade portuguesa exatamente por ser posterior à Revolução dos Cravos. Em meio a esse acontecimento alternam-se a euforia e a perplexidade de um país às voltas com a súbita transformação política, a circulação de ideias até então represadas, as consequências econômicas e sociais da crise do projeto colonial e, sobretudo, a dificuldade em lidar com a problemática modernização que, velozmente, se impõe à sociedade portuguesa e que aparece referida reiteradas vezes ao longo da narrativa.

$\mathrm{Na}$ verdade, a máxima panta rei, que resume a filosofia de Heráclito e remete à ideia de que tudo flui, nesta obra de Lídia Jorge acaba por revestir-se de uma conotação ambígua e irônica, tendo em vista que a ideia de impermanência corre em paralelo com alguns elementos que apontam para a noção de permanência, de durabilidade e estabilidade. Dois exemplos dessa permanência na impermanência podem ser constatados na recorrência dos vocábulos "pedra" e suas variações (farinha, balastreira, escultura, gesso etc.) e "palavra" (signo...), aos quais são contrapostos, em diversas etapas do percurso de autoconhecimento das personagens (Júlia, Fernando e Artur, principalmente) os atributos de maleabilidade e de dureza, rigidez, permanência. A ponderação sobre essas duas artes (a escultura e a literatura) é um dos muitos subtemas importantes e complexos da narrativa, e ainda será preciso mais leituras para dar conta de compreender o pleno sentido que lhes é dado na economia da narrativa.

Outro exemplo que aponta para a noção de permanência está no conteúdo da memória e das emoções da personagem Júlia. Denominado de "leitmotiv", o termo é extraído da música e representa um tema reincidente ao longo de uma obra. Neste caso, a campânula que Júlia visualiza interiormente nos seus encontros afetivos com Artur Salema e, por último, com Fernando Rita, traduz, muito romanticamente, no primeiro caso, a descoberta do amor; e, com Fernando, a possibilidade de descoberta (interior) de um modo de amor mais estável porque mais maduro.

Essa comunicação expressa com certa dificuldade acaba dando vazão à imaginação num tempo em que o real deveria ser evidenciado. Isso mostra que se tem, de um lado, a mulher que Portugal tem como modelo, aquela da tradição católica, submissa, obediente etc e, de outro lado, aquela que se pretende emancipada, luta pelo seu ideal e pelos seus direitos. Júlia acaba enquadrando-se nos dois tempos, pois pensa 
como a primeira, mas está situada no contexto da segunda. Trata-se, então de uma identidade presente na tradição da mulher portuguesa (identidade esta que lhe foi imposta pelos modelos pré-estabalecidos para as mulheres) e que precisa ser reconstruída nesse contexto de emancipação lançado a partir da segunda metade do século XX. Sendo assim, o nível de consciência que Júlia possui está pouco desenvolvido para perceber tais transformações e ainda enquadrar-se nesse novo formato de comportamento feminino. Isso se dá porque a protagonista mostra-se orientada pelo sonho, pela fantasia e acaba deixando-se envolver por esses elementos do imaginário, ou seja, pertencendo-se a outro e não a si mesma.

A personagem Júlia, embora possa ser considerada com certa limitação de consciência, também pode ser vista formando pares, o que parece reforçar ainda mais a sua condição amorfa e a sua busca pela singularidade, a partir do confronto com o outro. Um desses pares se dá entre ela e David, com quem se sentia feliz apesar dos vinte e cinco anos de diferença de idade. Depois, outro par se forma com Artur, por quem ela se apaixona. Em seguida, seu contato se volta para o Sr. Assumpção e, finalmente, ocorre a sua degradação, quando ela passa a se prostituir.

A relação com esses pares, com outro, que pretende um encontro com um "self", como afirmou Bakhtin, segundo o estudo feito por Clark e Houquist ${ }^{277}$, subentende uma aproximação tanto com o masculino quanto com o feminino. Em Notícia da cidade silvestre, o relacionamento de Júlia com as personagens masculinas se faz presente e isso se mostra de grande valia para o autoconhecimento da protagonista. Acredita-se que os relacionamentos com David Grey (seu marido), o Sr. Assumpção (dono da livraria onde trabalhou por um período), Saraiva e Mão Dianjo foram significativos para Júlia. À primeira vista, esses encontros e convivências parecem ser prejudiciais à mãe de Joia. Isso pode ser notado porque o primeiro relacionamento contribuiu para a submissão e estagnação de Júlia (enquanto foi casada com o artista se mostrava como uma esposa totalmente dependente e alienada, reflexo do comportamento que era imposto à mulher portuguesa em plena década de 70).

O contato com os outros impulsionou a prostituição de Júlia, "Alternava bem o Saraiva com o Mão Dianjo. Para isso era preciso usar uma poderosa agenda a fim de os não fazer encontrar. "278 Contudo depois dessa experiência de aprendizagem, Júlia pensou "em arranhar melhor a vida, já que nem um nem outro podiam fazer mais por

${ }^{277}$ CLARK, Katerina e HOLQUIST, Michael. Mikhail Bakhtin. São Paulo: Perspectiva, 1998.

${ }^{278}$ JORGE, Lídia. Notícia da cidade silvestre. 2. ed. Lisboa: Publicações Europa-América, 1984, p. 273. 
mim do que faziam. O Saraiva, talvez por trabalhar em seguros, só via uma solução - o

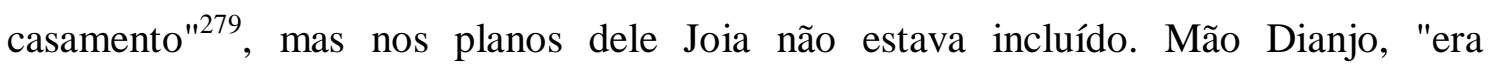
generoso, tinha uma visão comunitária do dinheiro, mas discutia a aplicação dos capitais até ao último tostão" 280 , por conta disso ele queria manipular os gastos de Júlia. Percebendo que os lucros eram poucos e as perspectivas mínimas, a protagonista decide se insinuar para o Sr. Assumpção,

como eu tinha a perna descoberta a frente, ele foi ficando vermelho e caiu de joelhos, agarrando-me as saias e por baixo delas. [...] Disse ao Sr. Assumpção - "São três." O Sr. Assumpção negociou - "Vamos partir ao meio? Só dou um e metade. Metade de três." "Pois seja" disse-lhe. O Sr. Assumpção ali entre os livros parecia estar a ter a delícia do mundo. ${ }^{281}$

Apesar da aparente negatividade que acarretam, esses relacionamentos ainda parecem contribuir para o desenvolvimento da protagonista, pois, ao longo da narrativa Júlia começa a perceber que pode progredir sem estabelecer relação total de dependência com um outro. Além disso, a prostituição se mostra como uma espécie de aprendizado, pois aquilo que, para ela, no início parecia ser algo natural começa a tornar-se perigoso. Isso é percebido quando a protagonista é perseguida por um taxista nas ruas e quase é morta. Depois de conseguir se safar, chega em casa e se depara com o filho Joia

Estava a dormir de luz acesa. Acordou espantado a olhar para o casaco que eu despia molhada até à cintura. Era para não lhe dizer nada, mas a sensação, não de poder ter morrido, mas de ser encontrada morta, dava-me uma vontade irreprimível de o chamar assim. "Jóia." Contarlhe alguma coisa sem lhe dizer a verdade. Aliás, aqui para nós, eu não tinha a noção de nenhum limite, era uma pessoa à roda dentro duma esfera, e onde os outros possivelmente diriam que seria o fim eu encontrava o princípio. Não interessa - Jóia era ao mesmo tempo discreto e sentido. [...] Era como se me dissesse, vai, não te justifiques, não te incomodo. Guardaria possivelmente para me dizer mais tarde, quando já fosse homem e já tivesse as palavras necessárias - "Eu sabia."

O trecho mostra que o fato de Júlia ter passado por momentos difíceis que quase lhe levaram à morte, a fez iniciar um processo de amadurecimento, a ponto de admitir: "não tinha a noção de nenhum limite", mostrando viver alheia ao mundo real. Além

\footnotetext{
${ }^{279}$ JORGE, Lídia. Notícia da cidade silvestre. 2. ed. Lisboa: Publicações Europa-América, 1984, p. 274.

${ }^{280}$ Ibidem, p. 275.

${ }^{281}$ Ibidem, p. 276-277.

${ }^{282}$ Ibidem, p. 287.
} 
disso, a partir daquele momento, ela parece perceber no filho certa maturidade que o faz discreto a ponto de não fazer nenhum comentário enquanto não soubesse utilizar as palavras certas (embora demonstrasse ter conhecimento de tudo o que estava acontecendo). Contudo Júlia decide, diante do espelho, "Não estou mais para isso" 283 e cessa com a prostituição.

Joia, apenas uma criança, chama Júlia à razão. No que dependesse da protagonista, "onde os outros possivelmente diriam que seria o fim eu encontrava o princípio." Ela parecia não estar conectada à realidade. Até mesmo o próprio amor pelo filho somente foi descoberto quando ela o viu debilitado em uma cama de hospital, na ocasião em que o menino tomou veneno de rato. Somente assim consegue avaliar que "era tão injusto que acontecesse ao Jóia, tão injusto se eu o amava tanto." 284

Até mesmo a paixão que acometeu Júlia quando se deparou com Artur Salema pela segunda vez, após o retorno dele da Itália, a fazia se comportar de forma inconsequente, despreocupada, como se existissem somente os dois no universo.

\begin{abstract}
Metidos no fundo do escuro, o tacto era fosforescente e os movimentos do corpo eram comandados por um vento que ondulava vagas, metros e metros acima do local submarino onde nos mordíamos. Uma coisa única, já o disse. Via que nunca tinha deixado de estar apaixonada pela segunda vez mas só agora descascava a paixão. [...] Apesar de nos termos amado a noite inteira, ainda vínhamos pela rua agarrados um ao outro como inválidos. ${ }^{285}$
\end{abstract}

Artur Salema era amigo de Anabela Cravo e foi por intermédio da amiga que Júlia o conheceu. Assim como Fernando Rita, João Martinho e também o falecido marido de Júlia, Artur fazia esculturas. Esse reencontro ocasionou uma paixão tão avassaladora que fez Júlia perder, ainda mais, os sentidos. Mas a ocorrência de uma gravidez inesperada e a indiferença demonstrada por Artur diante do fato fizeram Júlia desistir do visita alto (maneira pela qual ele era chamado por Anabela Cravo).

Depois de ter sofrido grandes decepções, a primeira pessoa que bate à porta do Atelier é Fernando Rita (o visita baixo), pedindo permissão a ela para expor suas esculturas no atelier nos finais de semana. Fernando aproxima-se de Júlia, demonstra carinho pelo Joia, fazendo questão, a pedido do menino, de buscá-lo no hospital porque o menino havia solicitado a Júlia: "Então o Fernando"286. Além disso, Fernando

\footnotetext{
${ }^{283}$ JORGE, Lídia. Notícia da cidade silvestre. 2. ed. Lisboa: Publicações Europa-América, 1984, p. 287.

${ }^{284}$ Ibidem, p. 295.

285 Ibidem, p. 184.

286 Ibidem, p. 298.
} 
"desfez-se, esperou durante horas, chegou atrasado a locais inadiáveis, fez companhia e acabou por comprar um dálmata" 287 . Júlia ficou muito agradecida e desde então começa a notar que Fernando era uma pessoa diferente.

De certa forma, o contato da protagonista com essas personagens masculinas parece ter sido muito relevante, mas a mola propulsora dessas transformações é Anabela Cravo, que funciona quase como um alterego de Júlia, ou, em outras palavras, como um espelho em que ela busca um rumo para suas ações. Na verdade, tanto uma quanto outra representam mulheres do período pós-revolucionário português: mulheres a quem não basta ser simples dona de casa, mulheres que desejam, mas não sabem como lidar com seus desejos e com seu corpo.

A alegria, exuberância e o olhar seguro de Anabela Cravo causavam encantamento em Júlia e a protagonista acreditava que a existência de Anabela era de grande valia para espalhar tensões e iluminar a vida: "Era na verdade uma mulher extraordinária, Anabela Cravo Dias, estudante, dactilógrafa, uma organização de vida prodigiosa que me fascinava." ${ }^{288}$ No princípio dessa amizade súbita, talvez Júlia não tenha percebido que estava nascendo em si certa submissão em relação a Anabela. Isso se dá devido ao fato de Anabela se mostrar, pelo menos aos olhos de Júlia, e acredita-se que também pelas suas ações, como símbolo de força e coragem porque, ao contrário de muitas mulheres, Anabela tinha uma profissão e exercia um trabalho fora do âmbito doméstico. Essas atitudes de uma mulher portuguesa no contexto da década de 70/80 realmente podem causar espanto e, ainda mais, admiração. Esse pode ser considerado um dos motivos que fizeram despertar em Júlia tamanho encantamento por Anabela.

Isso mostra também que, ao que parece, Anabela apresenta um grau de consciência pouco mais elevado em relação a Júlia. Há pelo menos uma tentativa, por parte de Anabela, em enquadrar-se naquele contexto em que os avanços dos movimentos feministas exercem, ou pelo menos deveriam exercer certo impacto sobre as mulheres da época. Ao contrário de Júlia, que se mostra um pouco desnorteada com a perda do marido e tenta encontrar em outro alguém uma espécie de proteção para continuar seguindo, Anabela, sem a proteção de ninguém, tenta adequar-se, a sua maneira, àquilo que a vida lhe oferece.

Essas duas personagens femininas remetem ao retrato da mulher portuguesa da segunda metade do século XX (mais especificamente após a Revolução de Abril de

\footnotetext{
${ }^{287}$ JORGE, Lídia. Notícia da cidade silvestre. 2. ed. Lisboa: Publicações Europa-América, 1984, p. 298.

${ }^{288}$ Ibidem, p. 50.
} 
1974) quando se leva em consideração o aspecto temporal da narrativa em questão, que se passa entre 1975 e 1979, mas remetendo, em flashback, também à década de 60 (mais especificamente 1964 e 1968). Mas, ao considerar o aspecto comportamental das personagens, principalmente o de Júlia, verifica-se que o retrato dessa personagem especificamente parece não condizer com o momento histórico pós-revolução de abril de 1974, mas talvez daquele que remete ao período do início do século XX, tempo em que a mulher vivia num período ditatorial, e que sempre se submetia aos comandos de alguém, ou seja, de uma figura que representasse força, fosse ela masculina ou não.

Esse período em que decorre a ação do romance pode ser também considerado um tempo em que a sociedade portuguesa (restringindo-se, na narrativa em questão, à sociedade lisboeta, pois esse é o local em que a ação se passa) estava passando por um momento de transformações devido a uma série de fatores "Espantoso como a vida corria, os jornais eram outros e as pessoas mudavam. Mesmo as que já não engordavam nem cresciam, compravam roupas, cortavam o cabelo e de repente apareciam mudadas..." 289 Trata-se de um período crítico para a sociedade portuguesa de modo geral, pois

O mundo vai estar de novo para quem abrir um balcão e puser duas mercearias atrás. Previam-se tuberculoses em barda, os médicos nos consultórios andavam a fazer gráficos agudos como picos de Evereste sobre o assunto. Os bairros de lata cresciam como crostas agarradas às periferias, o metro tinha cada vez mais pedintes, os bancos dos hospitais cada vez mais cheios de gente e menos desprovidos de recursos. ${ }^{290}$

Mas, para a mulher, o impacto era ainda maior, pois, como em grande parte das sociedades, a mulher naturalmente se encontra numa posição inferiorizada em relação à figura masculina e isso se dá pelo fato de a figura feminina ser vista numa condição inferior em relação ao homem desde os primórdios - como se fosse um estigma que está sendo carregado por séculos e séculos. Júlia e Anabela se mostram como retratos dessas mulheres inseridas nesse verdadeiro caos em que Portugal se encontrava naquele momento, mas cada uma a sua maneira.

Nesse contexto, embora a situação da mulher estivesse diferente daquela vigente no período ditatorial português, exatamente pelas mudanças que ocorreram devido à emergência dos movimentos feministas, a condição que remete à figura feminina ainda

\footnotetext{
${ }^{289}$ JORGE, Lídia. Notícia da cidade silvestre. 2. ed. Lisboa: Publicações Europa-América, 1984, p. 15.

${ }^{290}$ Ibidem, p. 71.
} 
se mostra com um grau de subalternidade em relação à figura masculina. Lídia Jorge, ao expor, no romance, o retrato da condição feminina, mostra que as personagens centrais Júlia e Anabela caminham rumo ao processo de amadurecimento e em busca de conquistar um lugar no mundo, em busca de uma consciência feminina. Mas, vale ressaltar que a busca dessa consciência se desenvolve em graus diferentes porque Anabela consegue perceber, com um pouco mais de clareza que Júlia, os acontecimentos que as circundam, ao passo que Júlia parece vivenciar outro contexto, que ainda não está muito bem articulado com a emancipação feminina.

É certo afirmar que as duas personagens já se deixam contagiar pelas novas conquistas daquela época quando se mostram trabalhando fora do âmbito doméstico, por exemplo. Esse fato pode sugerir que provavelmente a mulher já não vive mais completamente dependente de uma figura masculina que a sustente. Deve-se observar que o trabalho, para Anabela, surge por necessidade, por um desejo pessoal e também para conquistar sua independência.

Já para Júlia o trabalho que conseguiu na Livraria Assumpção, ela devia inteiramente a Anabela, pois a datilógrafa tinha feito funcionar uma cadeia de conhecimentos e amizades e isso propiciara a Júlia uma colocação profissional. Júlia sempre precisa de alguém para intermediá-la e esse é um dos motivos que faz o grau de consciência dessa personagem apresentar-se em escala menor em relação a Anabela.

Acredita-se que esse grau de consciência menos desenvolvido possa aproximar Júlia do contexto da mulher inserida no período que antecede à década de setenta, porque ainda se faz presente no íntimo dessa personagem a condição de subalternidade que provavelmente a faz sentir-se menor. $\mathrm{O}$ fato de Anabela ter um grau de consciência pouco mais elevado em relação a Júlia não a distancia completamente dos pensamentos e atitudes da mulher do contexto ditatorial porque ainda se faz presente em sua memória a condição de inferioridade que sempre foi imposta às mulheres. Isso mostra que, para conquistarem seu lugar no mundo, essas personagens precisam passar por um processo de reconhecimento de si mesmas, rumo à construção de suas identidades femininas.

Refletir a respeito da construção da identidade feminina observando as ações das personagens centrais do romance implica pensar em como se iniciou esse processo principalmente na personagem protagonista, Júlia Grei. Há indícios de que tudo começa a partir da morte do marido David Grei, quando Júlia se sente desnorteada e acaba apegando-se a Anabela Cravo. Ana se mostra uma mulher diferente de Júlia no que se refere ao estado civil, pois Ana nunca foi casada e tampouco teve filhos. No que se 
refere à liberdade de ir e vir, Júlia se comportava, enquanto esteve casada, como esposa (ser esposa naquele contexto significava obedecer e dedicar-se ao marido). Ao passo que a dedicação que Ana prestava ao seu padrinho (figura masculina que Anabela tinha como referência), desde os 13 anos, era outra, pois "um dia a Madrinha estava a dormir a sesta, ela a lavar a loiça, e o Padrinho tinha vindo a princípio para trás e tinha-a amado entre os jactos de água e os esfregões." 291

O processo de construção da identidade das personagens centrais, pelo que mostra a narrativa, foi impulsionado por algumas situações específicas vivenciadas por elas. No caso de Júlia, acredita-se que logo após a viuvez. Em relação a Anabela, talvez, o fato de ter sido abusada pelo padrinho tenha despertado uma reação e, partindo dessa situação, decidisse dar um rumo diferente a sua vida. Evidentemente o estreitamento da amizade e a intimidade que se constrói entre essas personagens também contribuem significativamente para o início do processo de construção da identidade de Júlia. Essa intimidade intensificou-se de tal forma que Anabela teve acesso até mesmo à chave do atelier de Júlia.

Com essa total violação de sua intimidade, Júlia demonstra o

desejo de mandar parar a algazarra, comprimir o braço de Anabela Cravo e dizer-lhe alguma coisa desagradável, já que todos pareciam divertir-se com os meus haveres sem ter pedido licença, como uma palhaçada de feira. Mas não o fiz. [...] já que nem por sonhos eu queria estar à volta do mesmo objecto com Anabela Cravo, sobretudo para a não perder. Sem ela eu tinha a certeza de que a vida iria murchar, esfarelar-se, tomar aquela cor ruim dos sós. Não que não houvesse outras pessoas importantes, mas Anabela era diferente. ${ }^{292}$

$\mathrm{Na}$ realidade, acredita-se que essa dependência criada em relação à figura de Anabela por parte de Júlia não seja algo desenvolvido, mas há indícios de que seja um comportamento enraizado na figura feminina portuguesa em razão do tratamento que a mulher recebia durante o período salazarista. Julia foi casada com David exatamente nesse período e, por estar inserida num contexto tão rígido, tinha que se apoiar em uma figura masculina porque esta era a representação do poder e da força. Anabela, exatamente por essa determinação, coragem e por demonstrar estar sempre à frente de qualquer atitude a ser tomada, inspirou confiança em Júlia e a fez pensar que, com a presença da amiga, uma verdadeira fortaleza, estaria segura, já que perdera a referência masculina com a morte do marido.

\footnotetext{
${ }^{291}$ JORGE, Lídia. Notícia da cidade silvestre. 2. ed. Lisboa: Publicações Europa-América, 1984, p. 137.

${ }^{292}$ Ibidem, p. 30.
} 
Essa dependência que se estabelece entre as personagens parece pertinente em outro romance de Lídia Jorge, A noite das mulheres cantoras. Publicado em 2012, o penúltimo romance da autora, assim como grande parte de seus textos, também retrata questões inerentes ao universo feminino. A semelhança se dá entre os dois romances, dentre outros aspectos, na relação de poder estabelecida não somente entre homem e mulher, como habitualmente (tendo como parâmetro as relações que se estabelecem na sociedade portuguesa, principalmente durante o período ditatorial governado prioritariamente por Antônio de Oliveira Salazar), mas entre mulheres.

Acredita-se ser pertinente apresentar elementos comuns aos dois textos para que se possa notar o comportamento da mulher portuguesa na década de 80 . Nos dois textos foi possível perceber que as mulheres (mesmo com o fim da ditadura portuguesa e com a liberdade conquistada devido aos movimentos feministas) ainda sentem a necessidade de se apoiar em uma figura que represente força (no sentido de tomar decisões, uma espécie de regente que norteia as ações da mulher e por extensão a de toda família). Mesmo que essa força não esteja marcada por uma figura masculina, como ocorre nos dois romances, a mulher ainda sente necessidade de uma figura que guie seus passos, suas atitudes, que lhe sirva de apoio.

A protagonista de A noite das mulheres cantoras, Solange de Matos, assim como Júlia Grei em Notícia da cidade silvestre, também se espelha em uma figura feminina; aqui, Anabela Cravo e lá, Gisela Batista. Solange e também as outras personagens que compõem o romance ficam maravilhadas com a força, a determinação e o poder de Gisela. Afinal, Gisela era vista como "a maestrina, a rainha, a mentora, a mestra, a capitoa da nossa barca, a primitiva do grupo." ${ }^{293}$ Por esse motivo, Solange afirma: "A minha admiração por Gisela permanecia intacta. Aliás, a minha admiração pela sua pessoa aumentava ..."294 e não conseguia entender "porque exercia um poder tão extraordinário aquela mulher, [...] Porque emanava da sua figura uma força de sedução tão imperiosa, tão inexplicável?" 295

Pelo que se percebe nesse romance, publicado em 2012, Gisela se vale de um poder de sedução, irresistível, aos olhos de Solange, e acaba induzindo as personagens femininas a se dedicarem inteiramente à música. Trata-se de um grupo de mulheres que, por um desejo de Gisela, acabam tornando-se cantoras, e Solange era quem compunha

\footnotetext{
${ }^{293}$ JORGE, Lídia. A noite das mulheres cantoras. São Paulo: Leya, 2012, p. 64.

294 Ibidem, p. 27.

295 Ibidem. p. 59.
} 
as letras. Para as meninas, o ato de cantar era visto, em primeira instância, como um hobby, mas Gisela encarava esse desafio com tanta seriedade que impunha ao grupo intensos ensaios e fazia questão de evidenciar a obrigatoriedade no cumprimento daquelas tarefas. Para darem conta de toda a imposição, as moças teriam que voltar todas as atenções àquilo, obedecendo a todas às ordens e caprichos de Gisela, e, consequentemente, desprendendo-se de seus sonhos, de suas próprias vidas.

Ainda assim, Solange idolatrava Gisela e ficava fascinada com o poder daquela mulher, cedendo a tudo que lhe era imposto, pelo menos no primeiro momento. Tamanha semelhança ocorre com Júlia em relação a Anabela. Há também nessa relação certo deslumbramento e Júlia não consegue se desvencilhar de imediato dos "poderes" de Anabela.

Essa relação de dependência que se evidencia por parte de Júlia e Solange, no que se refere a Anabela e Gisela respectivamente, para constituírem-se a si mesmas, aos olhos de Bakhtin ${ }^{296}$, é inerente à figura humana porque o "self" só se constitui por meio do diálogo que celebra a alteridade. Desse modo, "o mundo necessita de minha alteridade para lhe dar significado, eu necessito da autoridade dos outros a fim de definir o meu self ou ser o seu autor. O outro é, no sentido mais profundo, meu amigo, porque é somente do outro que eu posso obter o meu self.", 297

Os relacionamentos de amizade que se criam nos dois romances podem remeter também a uma relação de poder, porque, em alguns casos, o "outro" exerce sobre o "eu" certa autoridade para que haja a constituição do self, como se pode ver em Notícia da cidade silvestre e em A noite das mulheres cantoras, em que as relações entre as personagens parecem acontecer pelo viés da autoridade.

Destacando Júlia como mote, objeto do nosso estudo, verifica-se que está num processo inicial de constituição da consciência e isso só se estabelece quando se depara com Anabela. Por outras palavras, Júlia inicia o processo de construção de seu "self” ao entrar em contato com "outro", Anabela. Anabela também consegue exercer poder sobre Júlia não somente por meio de suas ações como também por meio da palavra, porque a datilógrafa, que era inicialmente estudante de direito, torna-se advogada e, com o seu dom de advogar, acaba persuadindo Júlia por meio da palavra.

Nota-se, então, que essa relação de poder existente entre as personagens parece contribuir para o despertar da consciência de Júlia. Sobre essa questão, Foucault adverte

\footnotetext{
${ }^{296}$ CLARK, Katerina e HOLQUIST, Michael. Mikhail Bakhtin. São Paulo: Perspectiva, 1998.

${ }^{297}$ Ibidem, p. 91.
} 
que seu funcionamento articula-se como "uma rede de relações de alto a baixo, mas também até um certo ponto de baixo para cima e lateralmente; essa rede 'sustenta' o conjunto, e o perpassa de efeitos de poder que se apoiam uns sobre os outros: fiscais perpetuamente fiscalizados". ${ }^{298}$ Tais considerações reafirmam a questão de que o poder se configura como uma instância transitória. E isso mostra, com respeito à narrativa em questão, que a situação de Júlia, posição de subalternidade em relação a Anabela, não perdura, o que pode ser percebido quando a protagonista percebe falhas no comportamento daquela que considerava sua mentora.

Sob o ponto de vista de Foucault, são as diversas interferências do dia a dia (com suas surpresas e eventualidades) que contribuem para o desenvolvimento das relações de poder. Assim ocorreu com a personagem central de Notícia da cidade silvestre: os acontecimentos e a situação na qual se encontrava a fizeram unir-se a Anabela de forma que a datilógrafa conduzisse a vida de Júlia. Evidentemente, as circunstâncias cotidianas que desencadeiam essas conexões, ainda com base nas palavras de Foucault, acabam interferindo, ininterruptamente, na construção da identidade que cada "indivíduo" entende como própria ${ }^{299}$. Como se nota, esse enfoque questiona o próprio estatuto de indivíduo e, pelo que postulou Foucault (1992), as necessidades e exigências sociais levariam esse sujeito a cumprir diferentes "funções de sujeito" ${ }^{300}$ Vale ressaltar ainda que, para o autor, essas funções ocasionam diferentes situações e habituais relações.

Em se tratando de Júlia, observa-se que o seu relacionamento com Anabela parece ter interferido e contribuído para um início de consciência de si para seguir rumo à construção de sua identidade. Acredita-se que, nesse caso, esse contato tenha suscitado em Júlia não ainda um questionamento sobre si como indivíduo, mas ao menos um prenúncio de reconhecimento de si parece ter sido despertado. A convivência com Anabela Cravo foi de grande valia para encorajar Julia, mas vale ressaltar que o seu envolvimento com as situações de seu cotidiano, inclusive com as personagens masculinas, foi também significativo para que ela começasse a construir sua autoimagem, ainda que de maneira precária.

Foucault também enfatiza que o poder só se exerce sobre sujeitos livres. Não há confronto entre poder e liberdade; ao contrário, a liberdade é condição de existência do poder. A relação de poder e a insubmissão da liberdade não podem ser separadas. Viver

\footnotetext{
${ }^{298}$ FOUCAULT, M. Vigiar e Punir: nascimento da prisão. Petrópolis: Vozes. 2005, p. 148.

${ }^{299}$ FONSECA, M. A. Michel Foucault e a constituição do sujeito. São Paulo: EDUC, 1995, p. 131.

${ }^{300}$ FOUCAULT, M. O que é um autor? Lisboa: Passagens, 1992, p. 83.
} 
em sociedade é viver em "relações de poder". Observa-se que essa relação de poder, primordial para que o indivíduo se constitua como tal, parece estimulá-lo a partir "da ideia que o indivíduo fará de si próprio, diante da obrigação de agir de tal ou tal forma, em função de tal ou tal preceito." ${ }^{301}$ Isto é, obriga-o a obedecer (e isso parece se evidenciar em Notícia da cidade silvestre quando se trata do comportamento de Júlia diante da figura de Anabela), e, em concomitância, estimula que participe sob a forma de vigilante, sem desatar as amarras (no caso de Júlia que tenta se desvencilhar, porém sem perder a dimensão das interferências cotidianas que contribuíram para seu relacionamento com Anabela).

Tendo como base a teoria de Foucault, para que se constitua como sujeito, Júlia é auxiliada pela "relação de poder" que estabelece com Anabela e, ao estabelecer essa relação, parece que o caminho é o início do processo de construção de um "self" (o self tal como o concebe Bakhtin).

Parece muito provável que tanto a teoria de Foucault como a de Bakhtin, apontam para o processo de construção da identidade. E para que esse processo tenha início, no caso da personagem central de Notícia da cidade silvestre, interessante será levar em consideração os valores socioculturais portugueses, por estar em evidência no romance a mulher lusitana. Por meio desses valores (em que atuam as crenças e atitudes) o indivíduo, num determinado tempo e espaço, acaba indo em direção à construção de si mesmo. Essa pretensão de "ser" só vai se constituir, ao que parece, numa relação de alteridade, um EU frente a outro (ou OUTROS), e somente assim o indivíduo pode construir uma identidade pessoal.

Com a personagem Júlia, mesmo enfrentando muitos percalços durante a sua trajetória (a viuvez, a criação de um filho sozinha, o trabalho fora do âmbito doméstico e a prostituição para garantir o próprio sustento e de seu filho) se comparada às protagonistas dos dois romances anteriores a esse, Branca e Rosária respectivamente, ela tem a seu favor o fato de estar inserida num contexto pós-Revolução dos Cravos, em que algumas transformações sociais podem favorecer a mulher oferecendo-lhe certa liberdade que, em outros tempos, não estava acessível às mulheres. Dentre essas transformações estão: o direito ao voto, o direito ao trabalho remunerado, ao aborto etc.

Esse último, a questão do aborto, que dominou a cena europeia, e inclusive portuguesa, entre as décadas de 60 e 80 está concretizada nos dramas vividos por

${ }^{301}$ FONSECA, M. A. Michel Foucault e a constituição do sujeito. São Paulo: EDUC, 1995, p. 101. 
Anabela e Júlia. O aborto causa sofrimento nas personagens. Isso pode ser notado por meio das impressões de Julia ao descrever a amiga em seguida ao aborto:

Anabela tinha desaparecido e em seu lugar havia uma pessoa seminua estendida de costas sobre uma marquesa de hastes, os tornozelos presos a duas correias. A cabeça quieta, pendida de lado, caia sobre um plástico cor de urina, ao fundo do corpo, como coisa sem importância. Era Anabela Cravo. [...] uma polpa de algodão branco sangrava. As plantas dos pés erguidas, os dedos náufragos. A primeira impressão que tive foi duma grande desgraça. Morreu, Anabela morreu. ${ }^{302}$

O aborto foi finalizado, porém em condições precárias porque se tratava de uma clínica clandestina. Além disso, Anabela já estava num estágio avançado da gravidez, e Dona Jacinta, a parteira, "se pôs a mexer com o dedo, mostrando as peças. 'Quem é que lhe falou a você em três meses? Quem foi?' [...] 'Isso que aqui está tem mais de cinco meses, já perto de seis' E remexia de novo nos destroços do pássaro, repetindo seis como um número trágico." 303

Mesmo sabendo que corria riscos, Anabela procurou a parteira para se livrar do bebê. Aos olhos de Anabela, a criança era indesejada por isso queria se livrar dela. A alusão que Dona Jacinta faz ao livro sagrado, quando repete "seis como um número trágico", remetendo ao número da besta, 666, citado no livro Apocalipse de São João, mostra que esse número, por ter uma conotação negativa, representa o mal e não traz sorte, assim como o bebê. Por isso, Anabela decidiu abortar esse filho, mesmo que lhe custasse a vida.

Além desse aborto, que pareceu traumático, Anabela também foi vítima de estupro, cometido por seu padrinho, já mencionado anteriormente. Em troca de silêncio, Anabela impôs "Pague-me os estudos, Padrinho, compre-me os livros e pague-me os estudos." ${ }^{304}$ Por conta dessa violência, veio à mente de Anabela a decisão de prostituirse e de estudar para poder manipular as pessoas ao seu redor, como os homens costumavam fazer.

Com Júlia, a repulsa inicial pelo aborto acaba tornando-se uma opção. O fato ocorreu no auge de sua paixão por Artur Salema e, ao perceber que ele estava afastandose dela quando soube da gravidez, resolve procurar dona Jacinta. "A abortadeira morava

\footnotetext{
${ }^{302}$ JORGE, Lídia. Notícia da cidade silvestre. 2. ed. Lisboa: Publicações Europa-América, 1984, p.131.

303 Ibidem, p. 132.

304 Ibidem, p. 137.
} 
no mesmo sítio e atendeu como antes, e era para já, segunda-feira seguinte. ${ }^{305}$ [...] A porta dela era a mesma e ela tinha as mesmas luvas, embora brancas quando abriu. a mesma sala vestida de encarnado com os mesmos reposteiros." ${ }^{306}$ Mas Júlia não queria contar a Artur o que tinha feito, simplesmente "meter-me-ia no quarto e diria a Artur Salema - "Perdi-o". "307 Diante da notícia, Artur mostra-se aliviado e Júlia parece decepcionar-se porque tomou tal atitude principalmente para satisfazer o desejo do homem que amava. Após demonstrar uma alegria contagiante, Artur Salema desperta em Júlia um misto de desapontamento e raiva, fazendo-a expulsá-lo de casa.

Nota-se, pelo cotidiano de Anabela e Júlia, que algumas transformações ocorridas na época em que se ambienta a ação do romance contribuíram para que algumas escolhas fossem feitas. Por exemplo, antes de ter surgido a lei sobre o direito ao aborto, a mulher não tinha direito de decidir. Esses direitos começam a emergir com o advento dos movimentos feministas. Percebe-se, por meio da narrativa, particularmente sobre essa questão do aborto, que isso ainda acontecia clandestinamente e que aquelas que se submetiam, corriam risco de morte. Isso mostra que, apesar da "permissão", as condições em que esses abortos eram feitos se mostravam muito precárias.

Outras questões também se evidenciam com o surgimento dos movimentos feministas e com isso surge também a oportunidade de as mulheres transformarem suas identidades de modo que pudessem atuar mais livremente. De fato, muitos direitos foram conquistados nesse período. $E$ o que se pretende, em meio a esses acontecimentos, de acordo com Alves e Pitangui "que as diferenças entre os sexos não se traduzam em relações de poder" ${ }^{308}$. Isso mostra, ainda sob o ponto de vista dos autores, que "o feminismo procurou, em sua prática enquanto movimento, superar as formas de organização tradicionais permeadas pela assimetria e pelo autoritarismo" 309 .

Sabe-se que, em Portugal, as formas de autoritarismo acabam sendo enraizadas na sociedade com muita severidade durante o regime de Salazar. Mesmo com o advento dos movimentos, continuam, principalmente as mulheres, ainda sendo vítimas de um sistema que as coloca numa situação de inferioridade em relação ao homem, mas mudanças já ocorreram, situações já se transformaram. A partir dos movimentos do

\footnotetext{
${ }^{305}$ JORGE, Lídia. Notícia da cidade silvestre. 2. ed. Lisboa: Publicações Europa-América, 1984, p. 229.

${ }^{306}$ Ibidem, p. 231.

${ }^{307}$ Ibidem, p. 232.

${ }^{308}$ ALVES, Bianca M.; PITANGUI, J. O que é feminismo. 2. ed. São Paulo: Brasiliense, 1982, p. 10.

${ }^{309}$ Ibidem, p. 9.
} 
século $\mathrm{XX}$, as vozes não estão mais timidamente tão silenciadas como antes. A mulher pode externar uma força que, até então, estivera camuflada por uma questão de sobrevivência, mas agora, nesse novo cenário, passa a existir a possibilidade de externar uma voz que não está mais totalmente silenciada. A garantia dessa voz ser ouvida e atendida é outro caminho muito longo a ser percorrido, mas já serviu para tirar a mulher da obscuridade.

Em se tratando de Júlia, é possível notar que, ao longo da narrativa, a protagonista passou por várias transformações e isso pode ter contribuído para o reconhecimento de si mesma. A aparente fragilidade de Júlia acaba sendo superada pela força que nela se evidencia quando começa a se reconhecer como mãe e, possivelmente, como mulher. Anabela, embora também tenha enfrentado muitos obstáculos, não somente parece se constituir como mulher, mas ainda, mesmo que de uma maneira muito sofrida e que parece ter lhe custado caro, consegue ascender profissionalmente, conquistando o título de advogada.

Sobre as transformações sociais relacionadas ao universo feminino, Yasmine Ergas, em seu ensaio intitulado O sujeito mulher: o feminismo dos anos 1960-1980 ${ }^{310}$, destaca as manifestações maciças que ajudaram a forçar mudanças na evolução da mulher: a campanha pela liberação do aborto e o acúmulo de leis reformistas a respeito das questões das mulheres que numerosos países aprovaram nas décadas de 70 e 80 do século XX. Vieram também outras leis: da igualdade de salários dos homens e mulheres; lei pela igualdade de oportunidades; lei de proteção ao emprego que estabeleceu a licença-maternidade obrigatória e remunerada, além de diversas outras. ${ }^{311}$

Houve um turbilhão de acontecimentos que avassalaram o mundo das mulheres, fazendo as condições de vida delas mudar significativamente. Isso se processou, de acordo com Ergas,

desde uma participação crescente na força de trabalho até ao aumento do número de divórcios e de famílias monoparentais [...] Mas ainda antes de estas mudanças atraírem uma atenção generalizada, já o "feminismo" tinha alcançado notoriedade, transformando-se no

\footnotetext{
310 ERGAS, Yasmine. O sujeito mulher. O feminismo dos anos 1960-1980. In: DUBY, Georges; PERROT, Michelle. História das mulheres no Ocidente. Porto: Afrontamento, 1991, v. 5: O século XX, pp. 583-611.

${ }^{311}$ No entanto, a situação na sociedade portuguesa afasta-se dessas conquistas e, mesmo depois das grandes mudanças provocadas pelas Novas cartas portuguesas e por outras obras de vanguarda de autoria feminina, a luta pelos direitos femininos ainda teve que continuar.
} 
símbolo da claramente renovada - e em grande parte inesperada afirmação das mulheres. ${ }^{312}$

O feminismo alcançou destaque mesmo com a oposição política e com os conflitos sobre os direitos específicos das mulheres. No mundo contemporâneo, o feminismo adquiriu significados diferentes para contextos diferentes. Isso mostra, de acordo com as palavras de Ergas que,

Na verdade, o feminismo não é um substantivo cujas propriedades possam ser definidas de forma exacta e definitiva; poder-se-ia dizer, antes, que o termo feminismo indica historicamente conjuntos variados de teorias e práticas centradas em volta da constituição e da legitimação dos interesses das mulheres. Nessa perspectiva, o que o feminismo é, ou foi, é mais uma questão histórica do que uma questão de definição. ${ }^{313}$

Com as modificações do universo feminista, de acordo com Ergas (1991), foi possível distinguir posições feministas radicais, socialistas e liberais. Essas posições encaravam os movimentos feministas e o feminismo como fenômenos alinhados com as ideologias políticas. Vistos sob esse prisma, os conflitos entre feministas eram apenas uma reprodução de polêmicas exteriores. Assim,

enquanto as feministas radicais se tornaram notadas por terem falado da autonomia feminina utilizando a terminologia dos movimentos anticoloniais de libertação nacional, a linguagem das feministas socialistas parece digna de nota pela sua consonância com as análises centradas na luta e nas contradições de classe; e enquanto tanto as radicais como as socialistas eram notadas por invocarem uma refundição total da ordem social, as feministas liberais distinguiam-se por sublinharem como era importante para as mulheres adquirirem direitos iguais, no seio de uma sociedade política e socialmente pluralista. ${ }^{314}$

Ao reconhecer a feminilidade como categoria de identificação política, as feministas procuram tanto construir como desconstruir a feminilidade. Isso se processa porque se desenvolve no pensamento e na ação das feministas um anseio de construir uma identidade feminina, mulher, dando-lhe um significado político sólido e uma necessidade de desconstruir a própria categoria mulher e destruir a sua história. Com isso, os feminismos contemporâneos parecem afirmar a diferença entre os sexos e

\footnotetext{
${ }^{312}$ ERGAS, Yasmine. Op. cit. p. 583.

${ }^{313}$ ERGAS, Yasmine. O sujeito mulher. O feminismo dos anos 1960-1980. In: DUBY, Georges; PERROT, Michelle. História das mulheres no Ocidente. Porto: Afrontamento, 1991, v. 5: O século XX, pp. 583-611, p. 590.

${ }^{314}$ Ibidem, p. 590.
} 
também negar a importância da diferença sexual como causa legítima da desigualdade, ou seja, as feministas são, concomitantemente, defensoras da igualdade e partidárias da diferença.

Sendo assim, como afirmou Ergas, pode-se considerar que a reivindicação das feministas de hoje seria a afirmação da igualdade de direitos para as mulheres e o objetivo específico seria a instauração de um mundo neutro do ponto de vista do gênero, porque, desafiando as ideias que baniam as mulheres para os seus "lugares próprios", as feministas tentaram libertar as mulheres das restrições de gênero. A autora ainda esclarece que três trabalhos se evidenciaram nos primeiros anos dos novos movimentos feministas: o interesse pela reconstrução da história das mulheres; a atenção consagrada à identificação das coordenadas que unificam a condição das mulheres em contextos diferentes; e a intensidade dos debates sobre as origens e implicações da diferenciação dos papéis e identidade sexuais.

É possível considerar que a "descoberta" da história das mulheres proporcionou a redefinição e a legitimação de um sujeito mulher, estabelecendo elementos comuns criando possibilidade de se identificarem umas com as outras, construindo uma memória específica de gênero. Esse processo contribuiu, evidentemente, para que as mulheres buscassem novos caminhos para seu próprio crescimento e para a construção de uma nova identidade. Por meio de maneiras muito variadas, as feministas lutaram para explicar a natureza das características comuns às mulheres, transgredindo as distinções tradicionais que demarcam o domínio do individual ou do privado em relação ao domínio do político ou do público. Ao denunciar a opressão das mulheres e os mecanismos de sua subordinação na família, o feminismo mostrou que o individual também é político. E isso questiona, de acordo com as palavras de Faria (1998),

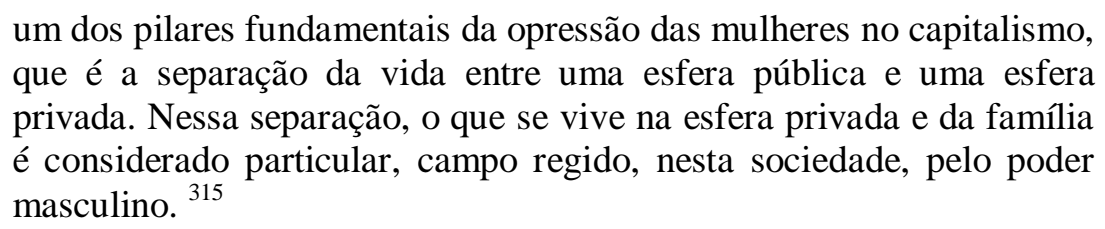

A questão de se considerar o individual como político não serviu apenas para afirmar que as feministas já não aceitavam as prerrogativas dos maridos no casamento ou a violência sexual (permanecendo confinadas aos escrúpulos da moralidade individual e, portanto, fora do alcance de toda discussão pública); denotava ainda, para

${ }^{315}$ FARIA, Nalu. Sexualidade e gênero: uma abordagem feminista. São Paulo: SOF, 1998, p. 22. 
as feministas, a importância da reconstrução do eu feminino. O feminismo evidenciou a importância de segregar maternidade de sexualidade; defendeu o direito das mulheres de expressar seu desejo sexual e construiu formas coletivas de expressão das mulheres. Atrelado a isso, veio à tona a questão da autonomia feminina e do poder de decisão e escolha e, ao questionar a supremacia masculina, o feminismo contribuiu também para construir o conceito de perigo sexual para as mulheres. Desse modo, ao concretizar a separação entre sexualidade e a imposição da maternidade, a luta feminista pelo direito ao aborto é fundamental para a emancipação das mulheres.

$\mathrm{O}$ feminismo denunciou ainda todas as formas de abuso e violência contra as mulheres e também o estupro dentro do casamento, antes considerado normal diante da suposta obrigação da esposa de servir sexualmente ao marido. Mostrou que a desvalorização generalizada do feminino definia um padrão de comportamento masculino de agressão permanente às mulheres e a visão delas como objeto de posse.

As ativistas femininas fizeram campanhas pelos direitos legais das mulheres (direitos de contrato, de propriedade, de voto); pelo direito à sua autonomia e à integridade de seu corpo; pelos direitos ao aborto e pelos direitos reprodutivos (incluindo o acesso à contracepção e a cuidados pré-natais de qualidade); pela proteção de mulheres e garotas contra a violência doméstica, o assédio sexual e o estupro; pelos direitos trabalhistas, incluindo a licença-maternidade e salários iguais, e contra todas as outras formas de discriminação.

Essa preocupação com a reconstituição do sujeito mulher encontrou ressonância numa pragmática desenvolvida pelos movimentos feministas em muitos países. Isso distingue a mulher da imagem que lhe foi construída ao longo dos anos, submissa ao lar e ao homem.

No romance em análise, parece ter sido assim com Anabela e Júlia. Elas estão inseridas nesse contexto e, por isso, tentam se enquadrar no crescimento ocorrido na década de 80, no que se refere aos direitos conquistados pelas mulheres. Além disso, parecem vivenciar essas mudanças, mas por meio de experiências muito dolorosas. Isso mostra que estar presente num contexto em que muitas transformações se desencadeiam e parecem favorecer o cotidiano da mulher, oferecendo a ela certa liberdade, não basta. Existe uma ânsia por liberdade, e isso pode ser evidenciado no comportamento das personagens, com mais ênfase em Anabela do que em Júlia, mas, para que seja colocada em prática, seria necessário percorrer um longo caminho. 
Acredita-se que essa liberdade só emergirá quando o indivíduo (no caso, a mulher) iniciar o processo de reconhecimento de si, ou seja, criar uma consciência dessa liberdade para assim poder usufruir. Trata-se de um processo interior, que precisa ser desenvolvido, gradativamente.

Com a personagem Júlia, esse processo de amadurecimento ocorre por intermédio de confidências que faz à sua interlocutora, focalizando acontecimentos e vivências de sua vida, vida que, didaticamente, pode ser distribuída em quatro fases. A primeira, quando apaixona-se por David Grei, professor 25 anos mais velho que ela, com ele se casa e juntos ficam até a morte dele, por suicídio. A segunda fase tem como eixo a figura de Anabela Dias Cravo e tem início logo depois da morte de David, quando Júlia vai ao escritório de Atouguia Ferraz para tratar do seguro do falecido e torna-se admiradora e amiga da secretária. Essa relação opera como parâmetro de outras relações e fases, razão pela qual a figura dominadora de Anabela permeia as demais etapas do percurso de vida da protagonista, com maior ou menor ascendência sobre ela. Outra fase é a da paixão por Artur Salema (aqui Anabela tem menor poder sobre Júlia). A seguinte, depois da partida dele para a Itália, para se casar com Celina, gira em torno da degradação de Júlia. Esta, deixando-se guiar pelo modelo da amiga, passa a se prostituir e, além de um ou outro encontro originado na rua (um deles com Rui, o piloto), tem dois amantes, o Sr. Assumpção, dono da livraria em que trabalha, e Mão Dianjo; e, além disso, tem um noivo, o Saraiva, funcionário da Companhia de Seguros Tranquilidade:

Para abreviar. Quando a Primavera chegou, eu tinha dois amantes e um noivo, um dos amantes remunerava taco a taco, e ainda me dava direito a chinfrim. Era esse precisamente o que sabia dos outros, compreendendo por inteiro a natureza humana. Ainda por cima só vi que mil e quinhentos escudos não era uma quantia baixa depois de andar nas ruas. ${ }^{316}$

O filho Joia é o responsável pela fase mais importante da vida de Júlia. Depois de o menino ter tentado envenenar-se com trigo-roxo, um poderoso raticida, acelera-se o processo de amadurecimento e evolução emocional da protagonista (pode-se, inclusive, pensar que, nesta etapa, se dará a conquista de sua identidade como mãe (e talvez até como mulher). Desta última fase, o leitor toma conhecimento por meio de relatos datados (cartas?) (ainda endereçados à mesma interlocutora), que se estendem por um

${ }^{316}$ JORGE, Lídia. Notícia da cidade silvestre. 2.ed. Lisboa: Publicações Europa-América, 1984, p. 285. 
período que vai de trinta e um de março, treze dias após a tentativa de suicídio de Joia/João Mário e a sua internação, até dois de maio. Nelas, esse assunto não é abordado direta e exclusivamente: o que parece ser mais importante é a manutenção dos laços afetivos com a interlocutora anônima, sempre à espera de Júlia no Together/Tonight.

A primeira carta, datada de trinta e um de março, inicia-se assim: "Não apareci como combinado. ${ }^{, 317}$ Interessante, porém, é que a carta continua como se a destinatária já soubesse dos acontecimentos narrados a seguir: "Passei a manhã inteira a rondar o Santa Maria à espera que o Jóia saísse, e afinal até a hora da visita acabou por terminar sem eu ter uma informação segura."318 Tampouco há linearidade no relato desse acontecimento trágico: não são respeitadas as orientações típicas dos relatos convencionais (o que aconteceu?; onde?; quando?; como?; por quê?); o relato mais circunstanciado do ocorrido com Joia se dá muito depois, no início do capítulo trinta e três:

Pergunta V. como se envenenou o Jóia. Não sei explicar. Deve ter guardado um punhado de grãos debaixo da cama dele. Ninguém podia imaginar, porque sempre que via os grãos roxos, tremia desalmado como se visse dinossauro vivo. Afinal desejava-os. Ele é que me enganou. Acho agora que devia ter essa idéia há muito dentro da cabeça.

Mas pergunta-me V. como se envenenou o Jóia e insiste. Não sei. De facto, eu mantinha a vida dividida, como bem sabe, mas amava o Jóia e ele tinha lugar preponderante em todos os meus gestos, mesmo quando o exterior lhe dissesse o contrário. ${ }^{319}$

Embora neste estudo as fases tenham sido enumeradas de modo sistemático, não é desta maneira organizada que elas surgem no relato de Júlia. Elas emergem ao sabor da memória e não são orientadas por nenhum esforço racional, mas sim, acima de tudo, por uma intuição dos sentidos (o que explica muito das sinestesias, imagens e analogias que percorrem grande parte do texto; explica, enfim, muito da linguagem poética que caracteriza grande parte da narrativa).

No entanto, a linguagem poética e a presença da intuição como fonte da percepção da protagonista não constituem uma exclusividade no texto de Notícia da cidade silvestre; ao contrário, como acontece normalmente nos textos pós-modernos e

\footnotetext{
317 JORGE, Lídia. Notícia da cidade silvestre. 2. ed. Lisboa: Publicações Europa-América, 1984, p. 61. ${ }^{318}$ A inferência que aqui se faz, justifica-se pelo uso dos artigos definidos, indicando que o assunto em pauta já era conhecido e que, por exemplo, a menção ao Hospital Santa Maria ali naquele contexto não seria de causar surpresa.

319 JORGE, Lídia. Op. cit. p. 291.
} 
particularmente nos de Lídia Jorge, a paródia, a ironia e, algumas vezes, um humor corrosivo dão um tom mais crítico ao relato, o que pode ser explicado pelo fato de este ser feito prioritariamente em flashback (sem, no entanto, deixar de apontar para o tempo futuro, como se vê, por exemplo, nas últimas páginas do relato, que anunciam não só o encontro, por meio do ato de escrever, da "cidade silvestre", como também a possibilidade (e esperança) de ter, na tranquila e confiante interação com Fernando Rita, uma possível relação de amor mais estável e consistente).

Reconhece-se ainda, no interior do recurso paródico, a intertextualidade com o texto bíblico, em momentos dispersos da narrativa, com a história do Chapeuzinho Vermelho, da literatura infantil ${ }^{320}$, no último capítulo, quando Júlia, com uma faca escondida na bolsa, vai ao encontro de Anabela pela última vez para um confronto decisivo, que estabelecerá, finalmente, as fronteiras entre ambas. Outro exemplo de intertextualidade (e de corrosão) pode ser visto logo depois que Júlia ameaça Anabela com a faca e consegue colocar limites em relação à ex-amiga. Feliz pelo resultado da sua ação, ela reage e suas palavras são uma paródia da máxima de Descartes ("Penso, logo existo"): "Meto medo, logo existo, logo existo, logo existo. Jóia existe, o Fernando existe." 321

Outro recurso dos mais importantes é a presença do autor (o "autor-criador" de que fala Bakhtin em "O autor e o herói na atividade estética", aquele que se distingue pela sua posição axiológica em face do herói, de seu mundo e das formas composicionais em que o objeto estético se materializa.) ${ }^{322}$ Em outras palavras, o conteúdo temático de Notícia da cidade silvestre - as confissões envolvendo o percurso existencial de Júlia na cidade de Lisboa (em termos de singularidade) e, de modo mais amplo, a trajetória de certos estratos da população portuguesa, bem como as ponderações sobre certos valores culturais que acompanham a formação/ou reconstrução daquela sociedade - essa temática não poderia ser desenvolvida por meio

\footnotetext{
${ }^{320}$ A pergunta que Anabela faz sobre o que Júlia desejava ao ir procurá-la, a resposta desta ("Ver-te") vem seguida de ponderações que, em nenhum momento, lembram a ingenuidade da moça apaixonada por Artur Salema ou da antiga admiradora entusiasta de Anabela Dias Cravo: "Creio que foi de tanto ter lido a história do Lobo e do Capuchinho em pequena que as artes da dissimulação me chegavam sem eu sentir, pois na verdade o lobo costumava falar assim, por frases curtas, sem explicação. "Ver-te" - disse eu cheia de lobo. In: JORGE, Lídia. Notícia da cidade silvestre. Lisboa: Publicações Europa-América, 1984. p. 317.

${ }^{321}$ JORGE, Lídia. Notícia da cidade silvestre. 2. ed. Lisboa: Publicações Europa-América, 1984, p. 321.

322 Cf. FARACO, Carlos A. "Autor e autoria". In: BRAIT, Beth. Bakhtin: conceitos-chave. 4. ed. São Paulo: Contexto, 2007, p. 38.
} 
de um formato convencional; precisa, ao contrário, dessa diversidade de estratégias formais.

É também o autor-criador o responsável pelo excedente de visão, aquele olhar que o herói não pode dirigir a si mesmo a fim de se conceder a completude, o acabamento, o que só o outro será capaz de fazer (neste caso, esse outro é o autor). A seguir, a explicação de Cristóvão Tezza sobre o autor-criador e sobre exotopia:

Para Bakhtin, o autor-criador é a consciência de uma consciência, uma consciência que engloba e acaba a consciência do herói e do seu mundo; o autor-criador sabe mais do que o seu herói. Temos aí um excedente de saber, e um primeiro pressuposto da visão de mundo bakhtiniana, um princípio básico: a exotopia, que podemos simplificar definindo-a como o fato de que só um outro pode nos dar acabamento, assim como só nós podemos dar acabamento a um outro. Cada um de nós, daqui onde estamos, temos sempre apenas um horizonte; estamos na fronteira do mundo que vivemos - e só o outro pode nos dar um ambiente, completar o que desgraçadamente falta ao nosso próprio olhar. $^{323}$

Em Notícia da cidade silvestre, a exotopia é uma presença bastante forte, visível ao longo de toda a narrativa. No primeiro capítulo, por exemplo, o episódio em que os dois visitas (o alto e o baixo) vão percorrendo o atelier observando as peças que ali estão e fazendo seus comentários sobre a condição da Arte e sobre o nível dos artistas merece o olhar valorativo da autora (de piedade pela degradação da cultura e da arte em Portugal àquela altura). Verifica-se, nesse contexto da década de 80 em Portugal, que há uma desvalorização da arte, pelo menos daquela que tinha certo valor no período que antecede à Revolução de 74. Naquele tempo, parecia que já não se dava mais tanta importância à arte, diferentemente do que ocorria em tempos anteriores em que "ainda as escolinhas estéticas demoravam séculos." 324

Enquanto os súbitos convidados de Anabela Cravo, o visita alto e o baixo, observavam a obra de arte de David (ex-marido de Júlia) e faziam seus comentários, Júlia sentia-se incomodada com a passeata,

não porque se sentisse responsável pelas obras de David Grei, mas sim porque o facto de viver ali provisoriamente me levava e um desleixo

\footnotetext{
323 TEZZA, Cristóvão. “A construção das vozes no romance”. Texto apresentado no Colóquio Internacional "Dialogismo: Cem Anos de Bakhtin" (novembro de 1995; Departamento de Linguística da FFLCH/USP.) Publicado em Bakhtin, dialogismo e construção do sentido. Campinas: Editora da Unicamp, 2001; organização de Beth Brait. Disponível em http://www.cristovaotezza.com.br/textos/palestras/p_vozesromance.htm Acessado em 20 de novembro de 2012.

${ }^{324}$ JORGE, Lídia. Notícia da cidade silvestre. 2. Ed. Lisboa: Publicações Europa-América, 1984, p. 26.
} 
compreensível. Pelos peixes de madeira e outras figuras esguias que havia pelas bancas, o Jóia tinha ido deixando bonés, bandeiras, umas blusas penduradas ao acaso. A umidade dos últimos dias também me tinha levado a atar um cordel entre duas cabeças de bronze e daí baloiçavam meias e lenços, outras roupas leves numa cena de subúrbio. ${ }^{325}$

O descaso evidenciado por Júlia quando utiliza as obras de arte construídas por David para pendurar objetos remete à desvalorização daquilo que anteriormente era considerado importante para David Grei e para João Marinho, outro aficcionado por esculturas. Para os artistas mais jovens, o visita alto e o baixo, isso também ocorria, não porque sentiam prazer em depreciar obras de arte, mas pelas circunstâncias do momento,

Por imbecilidade, por estreiteza de alma, havia negociantes de toda a mixórdia, vendedores ambulantes de toda a natureza, traficantes de toda a espécie, tudo promovido pelos poderes públicos, e não havia canteiros. "Não, já não há!" - dizia o alto para o baixo. "E se tu precisares de fazer fundir uma peça é o mesmo. Fica a saber que hoje em Portugal se funde pior que há mil anos." [...] Uma espécie de anúncio de decadência fatal. ${ }^{326}$

Verifica-se um momento muito conturbado para as artes. É interessante que o excedente de visão não recai sobre uma determinada personagem apenas, mas sobre a situação em si, como um todo. Diante disso, as perspectivas para uma reconstrução e revalorização no campo artístico parecem ser mínimas.

Continuando as andanças pelo atelier de David, os jovens artistas se deparam com uma mulher de gesso e também se aproximam

da pedra móvel que havia a meio do atelier, donde uma pomba apenas meio liberta estendia as asas entre a mesa e a cama. Azul-cascais, cinza-baço. [...] A Pomba de David tinha asas e olhava de frente com cabeça de mulher, a feição meio desgastada, e lembrava vagamente os volumes duma velha esfinge... ${ }^{327}$

David passou anos, a pedido do amigo que lhe dera a oportunidade de trabalhar no atelier (Mão Dianjo), esculpindo aquilo que, para ele, poderia simbolizar paz, uma pomba, já que estava na euforia de setenta e quatro, momento crucial do fím da ditadura. Mas Mão Dianjo, com os seus ideais revolucionários, ficou decepcionado, pois esperava que "viesse a fazer em estatuária a descrição da resistência, legível, épica, para

\footnotetext{
${ }^{325}$ JORGE, Lídia. Notícia da cidade silvestre. 2. Ed. Lisboa: Publicações Europa-América, 1984, p. 25.

326 Ibidem, p. 26.

327 Ibidem, p. 26.
} 
que não se perdesse da memória da vista a pressão interior tão longa." ${ }^{328}$ Para Mão Dianjo o símbolo da paz não representava Portugal porque a paz remete à resolução dos problemas, quando na realidade aquele talvez pudesse ser considerado o grande recomeço.

Nota-se, por meio de David Grei e Mão Dianjo, que a arte, no período que antecede à revolução, tinha certo valor e, sobretudo para Mão Dianjo, poderia ter um valor transformador. Mas devido às dificuldades pelas quais Portugal está passando na década de 80 (nos campos cultural e econômico), o setor artístico se mostra em declive.

Fernando Rita (o visita alto), mesmo num momento em que a arte se apresenta em estado de degradação, parece ter a intenção de tentar resgatá-la, e, consequentemente, esse é o aspecto de resgate interior que a arte parece propiciar ao artista, quando pede a Júlia para ocupar o atelier com o intuito de produzir suas esculturas. Afinal, ao construir uma obra de arte, o artista procura externar não somente sua criatividade e suas habilidades, mas também realiza o que vê, ouve e, principalmente, seus sentimentos. Sendo assim, ao que parece, o artista, ao desenvolver uma obra de arte, deixa vir à tona o conhecimento que mora dentro de si.

Quando Fernando pede permissão a Júlia para utilizar o atelier, evidentemente há uma aproximação entre os dois e isso pode ser válido para o processo de descoberta interior da protagonista. Aliás, a presença de Fernando Rita também faz bem ao menino Joia e proporciona ao garoto, agora utilizando seu verdadeiro nome João Mário, uma liberdade que era própria dos meninos de sua idade. "João Mário se pôs a correr sem chapéu e sem cão, os punhos ao alto como os atletas. [...] fazia voltas e travessias como se quisesse recuperar alguma coisa [...] era como se tivesse nascido e fosse príncipe" 329

Para Júlia, não somente a convivência com Fernando Rita parece ter sido benéfica para a descoberta de si como também a prática de escrever relatos em uma espécie de diário de capa amarela. O caderno parecia, aos olhos de Júlia, ter certo valor. Por esse motivo, quando decide se desfazer do objeto "um caderno amarelo com quase dez anos de escrita" 330 resolve vendê-lo, oferecendo-o à interlocutora oculta ao encontrá-la no bar Together/Tonight.

Há indícios de que esses anos de escrita podem ter contribuído para o início de uma descoberta interior da protagonista. Sendo assim, acredita-se que a intenção de

\footnotetext{
${ }^{328}$ JORGE, Lídia. Notícia da cidade silvestre. 2. ed. Lisboa: Publicações Europa-América, 1984, p. 92.

329 Ibidem, p. 306.

330 Ibidem, p. 298.
} 
Júlia em vender o diário e não simplesmente doá-lo pode agregar ao objeto algum valor. Esse significado que Júlia atribui ao caderno talvez se deva ao desenvolvimento interior que a escrita pode ter-lhe proporcionado. Além disso, quando entrega o caderno, demonstra autoconfiança ao dizer: "Claro que não lhe ia explicar que me tinha munido da maior faca de cozinha, mas já a usava quando nesse dia lhe passei o caderno de capa amarela para a mão" 331 Júlia não somente, desde então, descobre alguma afeição pelo filho, como também está armada para qualquer eventualidade que possa surgir, demonstrando intenção de autodefesa, algo que dificilmente aconteceria em outros tempos.

O ato de escrever, nessa narrativa, relatos datados, parece não ser exclusividade em Notícia da cidade silvestre; em $O$ cais das merendas a protagonista Rosária também escreve cartas à mãe. No caso da protagonista do primeiro romance, $O$ dia dos prodígios, Branca, ela não desenvolve o dom da escrita, mas borda. Tanto a escrita quanto o bordado são afazeres que as personagens desenvolvem com as próprias mãos e, parecem iniciar o resgate da consciência de si quando desenvolvem essas atividades. Isso ficou evidenciado em Branca (quando o bordado não somente proporcionou um início de descoberta de si, mas também resgatou nela um dom que estava adormecido, o de adivinhar). Em Rosária, as cartas que escrevia para a mãe fizeram a personagem trazer à tona alguns conflitos interiores, por exemplo, expor à mãe a dúvida que tinha entre permanecer no espaço da Redonda ou trabalhar no hotel. Provavelmente esse conflito acabou ocasionando a morte de Rosária, mas contribuiu para que ela questionasse a si mesma.

Em se tratando de Júlia no romance em questão, quando expõe suas dúvidas e angústias à interlocutora por meio dos relatos, nota-se que essa parece ser uma forma de conhecer-se, como se estivesse relatando a si mesma quem é. Sobre essa questão da escrita a própria autora, Lídia Jorge, revelou em uma entrevista que deu à Revista LER o seguinte:

Quando escrevo não estou pensando propriamente nisso, mas no fundo sinto-me a construir uma espécie de proposta de figuras que falam em voz alta, lentamente, colocadas numa espécie de espaço meio penumbroso, onde algumas coisas podem brilhar, onde certas vozes podem brilhar com intensidade. E a sensação que tenho - que é boa e que não há leitura nenhuma, exterior, que me possa nem diminuir nem acrescentar, porque é uma experiência pessoal, inicial -

${ }^{331}$ JORGE, Lídia. Notícia da cidade silvestre. 2. ed. Lisboa: Publicações Europa-América, 1984, p. 298. 
é essa de estar em construção e em harmonia com essa espécie de cidade interna. ${ }^{332}$

Pelo que se percebe no relato da autora, a escrita não somente proporciona um autoconhecimento, mas também, e sobretudo, um reencontro interior que propicia uma construção de si. Além disso, Lídia também afirma que "o nosso amor-próprio, se acreditarmos em nós, tem de levar a carruagem com mais força do que aquela que puxa em sentido contrário. [...] Têm de acreditar que o seu amor-próprio é mais forte do que tudo o resto." ${ }^{333} \mathrm{E}$, ainda para a autora, o que se mostra como vitamina para o amor próprio é a escrita.

Com Júlia, parece ter ocorrido o início do despertar para a vida a partir do momento em que começa a escrever e a protagonista demonstra ter essa percepção quando resolve retomar a prática da escrita. A decisão acatada por Júlia (retorno à escrita), unida à perspectiva de reconstrução de Fernando Rita, podem ser o caminho para o despertar da identidade feminina e da cultura portuguesa.

Por meio do questionamento feito por Júlia a Fernando e diante da resposta e atitude do ex-visita alto, se evidencia a preocupação que o amigo da protagonista demonstra em contribuir de alguma forma para o desenvolvimento do processo sociocultural português.

"Fernando, ó Fernando, partiste a pedra, foi?" [...] "Não, não parti" Foi-se embora. [...] Fui atrás dele, até porque o meu amigo não ia a direito. Tinha agarrado num frasco de água com que ia molhando em pequenos esguichos os milhares de pedaços de pedra. Havia nelas a lembrança de formas vegetais e animais dum tempo ainda sem homens. Mas tinham sido feitas para que alguém as visse. "Podemos não ter mais nada, mas lá pedras temos das melhores da Terra. Olha aqui." 334

A iniciativa de Fernando em regar milhares de pedras com "pequenos esguichos", mesmo sendo um mineral impossível de ser rompido com água, remete a uma tentativa de reconstrução. Segundo a lenda de Prometeu, há uma relação estreita entre a alma e a pedra.

A pedra e o homem apresentam um movimento duplo de subida e de descida. O homem nasce de Deus e retorna a Deus. A pedra bruta desce do céu; transmutada, ela se ergue em sua direção. $O$ templo

\footnotetext{
${ }^{332}$ Lídia Jorge: vendo a alma por um livro. Entrevista de Carlos Vaz Marques. Revista LER, 2011, pp. 2886, p. 36.

${ }^{333}$ Ibidem, p. 36.

${ }^{334}$ JORGE, Lídia. Notícia da cidade silvestre. 2. ed. Lisboa: Publicações Europa-América, 1984, p. 306.
} 
deve ser construído com pedra bruta, não com pedra talhada... [...] A pedra talhada não é, com efeito, senão obra humana; ela sacraliza a obra de Deus, ela simboliza a ação humana que se substitui à energia criadora. A pedra bruta era também símbolo de liberdade; a talhada, de servidão e de trevas. ${ }^{335}$

Ao conservar a pedra em seu estado bruto, Fernando demonstra ter esperança em relação ao futuro da sociedade portuguesa. Talvez ele acredite que, tentando "regar" a pedra para que mantenha o estado puro, a possibilidade de reconstrução seja maior. Embora a pedra natural, entre algumas simbologias que se aplicam ao mineral, seja considerada "símbolo de liberdade", sabe-se que Portugal, na época em que se passa a história, mesmo com o advento da Revolução dos Cravos, não atingiu o momento de liberdade. Estão sim livres da ditadura, mas ainda viviam um momento muito difícil no que se refere à reestruturação social e cultural do país.

Na narrativa, Fernando Rita, faz questão de manter a pedra em seu estado original, pois talhada, como se verifica em Chevalier (2005), remete ao símbolo "de servidão e de trevas". Transpondo para a sociedade lisboeta, a "pedra talhada" refere-se à estagnação da sociedade, ao não desenvolvimento, pois ela, partida, subentende dispersão e, de certa forma, dificulta o processo de reconstrução, ao passo que a pedra, em seu estado natural, pode remeter a uma preservação e, a partir daí, propiciar a evolução da sociedade no sentido de reconstruir não somente o espaço externo, melhorando as condições de sobrevivência, como também o interno, desenvolvendo no indivíduo uma consciência de si que, consequentemente, auxilia na convivência social.

Como se vê, a postura adotada por Fernando Rita faz crer que a personagem parece ter mesmo a intenção de resgatar a cultura portuguesa e pretende, para que isso se concretize, valer-se da arte. Já Júlia pretende dar início ao processo de construção da identidade feminina por meio da escrita. E isso vem à tona em alguns trechos do romance, mas, principalmente, nas últimas páginas, quando diz: "possuo um monte de papel à mão, e assim que tudo sossega, deslizo pelas folhas a ronceira da esferográfica. É tudo o que tenho feito. Quando isso acontece, o mundo abre, fecha sua cortina, a vida transfigura-se." 336

A escrita passa a fazer parte da vida de Júlia, e isso faz evoluir a consciência de si, como se sentisse e pudesse, a partir dessa "frágil matéria" (maneira pela qual ela

\footnotetext{
335 CHEVAliER, Jean; GHEERBRANT, Alain. Dicionário de símbolos: (mitos, sonhos, costumes, gestos, formas, figuras, cores, números). 19. ed. Rio de Janeiro: José Olympio, 2005, p. 696.

336 JORGE, Lídia. Notícia da cidade silvestre. 2. ed. Lisboa: Publicações Europa-América, 1984, p. 322.
} 
descreve o papel), "dar notícia de outra realidade" ${ }^{337}$ Uma realidade que antes, talvez, pudesse estar escondida no íntimo da personagem, mas agora ressurge e parece encorajá-la para recomeçar na companhia de João Mário (seu filho) e Fernando Rita (o ex-visita alto e agora seu companheiro).

Neste terceiro romance, Lídia Jorge mostra que há uma evolução significativa em relação aos dois primeiros romances, no que se refere à busca do conhecimento de si rumo à construção da identidade feminina. Isso se dá, de acordo com a temática discutida nesse romance, pelo viés da literatura, mais especificamente da escrita. No quarto romance, que também integra o corpus deste trabalho - A costa dos murmúrios a protagonista Eva Lopo não escreve somente por hobby, mas se mostra como escritora, conforme já está evidenciado no começo, quando a narrativa se inicia com um conto escrito por ela. Sendo assim, Lídia Jorge faz o leitor crer que a escrita se mostra, cada vez com mais clareza, como uma espécie de porta-voz da esperança e da reconstituição identitária da mulher. Esse aspecto será analisado no capítulo que se segue.

${ }^{337}$ JORGE, Lídia. Notícia da cidade silvestre. 2. ed. Lisboa: Publicações Europa-América, 1984, p. 322. 
CAPÍTULO IV

A COSTA DOS MURMÚRIOS: VESTÍGIOS DE GUERRA E CONSTRUÇÃO DA IDENTIDADE FEMININA 
Assim como Notícia da Cidade Silvestre, A Costa dos Murmúrios, de 1988, também trata dos problemas de uma mulher confrontada com transformações e mudanças numa época histórica turbulenta. De fato, a temática feminina continua, mas acrescida de uma nova questão: a Guerra Colonial. Os acontecimentos evocados neste romance se passam em Moçambique durante a Guerra Colonial, que levaria ao colapso do Estado Novo, em abril de 1974.

A obra se divide em duas partes: o conto Os gafanhotos (narrado em terceira pessoa, ele não somente coloca em segundo plano a guerra em cujo contexto decorre o feliz acontecimento - a festa de casamento de Evita e Luís Alex - como também mostra uma perspectiva otimista, mesmo quando faz referência a mortes sucessivas) e a segunda parte, em que aparece a protagonista, Eva Lopo, já em sua fase adulta. A todo tempo, a narradora faz referências à primeira parte, numa superposição de planos presente e passado - e de espaços - o da Guerra Colonial e o do pós-guerra. A narradora apresenta, nessa segunda fase, uma visão bem mais crítica da realidade, pondo em evidência o vazio e a falta de objetivos no quotidiano das mulheres dos oficiais durante as longas ausências dos maridos. Numa espécie de desconstrução do que ocorre no conto, Eva Lopo, na segunda parte da obra, revisita, sob uma outra perspectiva, os acontecimentos vividos vinte anos antes.

Em primeira instância, a atenção se volta para a primeira parte do texto, o conto Os gafanhotos, que transporta o leitor para um passado colonial em Moçambique, território africano, no ano de 1968. À primeira vista, a situação apresentada nesse conto conspira a favor de um universo perfeito, em que um casal de jovens apaixonados compartilha a cerimônia de seu casamento com outras pessoas também aparentemente transbordando de felicidade. Trata-se de um momento festivo ocorrido no interior de um hotel, o Stella Maris, onde moram as esposas dos alferes e dos capitães e também os militares, quando não estão em combate.

O hotel foi construído na cidade de Beira, em meio à praia, e suas janelas se abriam ao Índico. No terraço do Stella Maris, obviamente, não havia janelas, apenas pilares sobre os quais se estendia uma cobertura suave" ${ }^{338}$, que acabou tornando-se uma espécie de altar onde seria realizada a cerimônia do casamento. $\mathrm{O}$ ambiente parecia significativamente harmonioso e luxuoso e isso pôde ser notado até pela noiva (a quem todos chamavam simplesmente Evita), que tinha chegado apenas na noite anterior ao

${ }^{338}$ JORGE, Lídia. A costa dos murmúrios. Lisboa: Dom Quixote, 1988, p. 9. 
casamento: [Evita] "surpreendeu-se com o tamanho exemplar da mesa. As lagostas vermelhas e abertas ao meio [...] Os ananases como se fosse um leque dum fantástico e emplumado peru." ${ }^{339}$ Todo esse luxo, associado à fartura e ao requinte, oferecia a Evita uma felicidade que talvez jamais tivesse experimentado, "pondo o véu completamente para trás e rindo cada vez mais." ${ }^{340}$ Mas, obviamente, "o local que Evita, docemente empurrada pelo noivo, deveria ocupar, não era ao centro [...] antes na cabeceira, onde havia um bolo de sete andares, com um ramo armado em forma de chuva." 341

Evita, mesmo ocupando supostamente uma posição de destaque, pois em um casamento a noiva deve ser o centro das atenções, foi induzida a posicionar-se atrás de "um bolo de sete andares", cedendo sua posição de destaque - que se esperava que fosse dela - ao noivo, figura masculina, que, de acordo com as convenções de uma sociedade patriarcal, deveria ocupar sempre uma posição de evidência. Nesse trecho, cuja descrição remete a um momento importante e decisivo na vida de uma mulher (casar, constituir família), pelo menos do ponto de vista da sociedade tradicional portuguesa da época em que se passa o conto (1968), está nítido que a figura da mulher deve ser sempre ofuscada quando estiver diante da presença do homem, em qualquer circunstância.

No romance, as experiências vividas pelas personagens, especificamente as femininas (levando em consideração que, apesar de estarem situadas em Moçambique, no continente africano, o hotel ali construído somente para abrigar os oficiais portugueses e suas esposas em razão da Guerra Colonial, mostra-se como uma extensão de Portugal), apontam para a submissão feminina em relação ao homem. O contexto de Guerra Colonial e também de ditadura em Portugal acaba favorecendo esse comportamento.

Em contrapartida, o ano de 1968, datado como o período em que se passa a primeira parte da narrativa, tornou-se um ano mítico, porque foi o ponto de partida para uma série de transformações políticas, éticas e comportamentais que afetaram as sociedades da época de uma maneira irreversível. Seria o marco para os movimentos ecologistas, feministas, das organizações não governamentais (ONGs) e dos defensores das minorias e dos direitos humanos. Deu-se uma espécie de furacão humano, uma generalizada e estridente insatisfação juvenil, que varreu o mundo em todas as direções.

\footnotetext{
339 JORGE, Lídia. A costa dos murmúrios. Lisboa: Dom Quixote, 1988, p. 10.

340 Ibidem, p. 10.

341 Ibidem, p. 10.
} 
É provável que essa efervescência causada por reivindicações não estivesse presente, pelo menos de forma visível, em Portugal por causa da rígida ditadura de Salazar. Mas aqueles um pouco mais esclarecidos acabaram tendo acesso a certas informações e, mesmo involuntariamente, influenciados por determinadas condutas.

A protagonista de A costa dos murmúrios pode ser um exemplo disso, pois, apesar de viver num contexto ditatorial, Evita, antes de se casar com Luís Alex, era estudante de História e, muito provavelmente, teve algum conhecimento sobre os movimentos estudantis que ocorriam nas universidades em outros países da Europa. Além dessa ânsia por descoberta, acredita-se que Evita tenha sido influenciada, de maneira positiva, por toda a atmosfera que permeou aquele tempo de 1968 (em que jovens se empenharam para iniciar um processo de transformação, no sentido de partirem em busca de uma liberdade no que se refere ao desvencilhamento daquele momento de repressão pelo qual passavam). Acredita-se que não seja gratuito o retorno especificamente ao ano de 68, pois a autora parece chamar atenção para esse contexto exatamente por ser um período conturbado e de muitas transformações.

O fervor dos movimentos da época pode ter encorajado Evita a externar suas opiniões. Aí talvez esteja um dos motivos para o possível despertar da percepção voltada para os acontecimentos do seu entorno, ou seja, o desenvolvimento de uma visão que ultrapassa os limites do aqui e do agora. Ao contrário dos moradores do Hotel Stella Maris, principalmente as mulheres, que se mostram com uma visão limitada. Percebem somente o interior luxuoso do recinto, reduzindo-o ao seu universo particular. Parecem se sentir como se estivessem protegidas em uma fortaleza impossível de ser invadida. Mas um hotel remete a um local de trânsito, em que as pessoas não se fixam, não estabelecem raízes. Isso mostra que o lugar considerado pela maioria daquelas mulheres como uma fortaleza, na realidade aponta para uma instabilidade, porque somente permanecerão ali enquanto durar a Guerra Colonial.

O interior do hotel tem um status diferenciado em contraposição ao espaço do colonizado moçambicano, que os portugueses vislumbram para além da janela. Essa abertura, geralmente situada na parte externa de uma edificação, destina-se a proporcionar iluminação e também ventilação ao interior. A janela facilita, ainda, a visibilidade da paisagem exterior. Sendo assim, de acordo com Chevalier e Gheerbrant, "a janela simboliza receptividade" ${ }^{342}$, como se, por meio desta abertura, adentrassem

${ }^{342}$ CHEVALIER, Jean; GHEERBRANT, Alain. Dicionário de símbolos: (mitos, sonhos, costumes, gestos, formas, figuras, cores, números). 19. ed. Rio de Janeiro: José Olympio, 2005, p. 512. 
somente coisas boas. No entanto, pelo que se nota em A costa dos murmúrios a visão que se tem através da janela e também do terraço não possui uma conotação positiva.

Primeiramente, na altura da festa de casamento de Luís e Evita, ouvem-se, "perto do Stella Maris, [...] grandes correrias de negros [...] pela avenida e gritos..." ${ }^{343}$ Diante disso, Luís, "espreitando pela abertura da janela" ${ }^{344}$, diz a Evita que não tenha medo. Mas o barulho se intensificou e, no instante seguinte, estavam todos no terraço, vestindo trajes de dormir.

Mas não era para a barra que estavam a olhar e sim para o Chiveve, o braço de mar que ali defronte fazia uma profunda peça, para onde, durante a noite, a água tinha arrastado corpos de gente afogada. Imensos, incontáveis afogados. [...] "Parece que além, às portas do cabaré, ainda estão pilhas deles. Ora enxerguem..." [...] "Numa noite destas devíamos ter ficado acordados. Nunca mais vamos experimentar a emoção que poderíamos ter tido!" - A mulher tinha os binóculos do marido colados aos olhos. ${ }^{345}$

Avistavam uma tragédia: pessoas (negras) mortas por envenenamento, vítimas de uma violência peculiar ao ambiente da Guerra Colonial, mas vistas pelos hóspedes como mais um atrativo para aquela noite memorável.

O fato, ocorrido na madrugada da festa do enlace matrimonial, poderia ser visto como um espetáculo (exclamou a mulher do capitão piloto-aviador). Ela ainda lamenta por não terem ficado acordados, para "experimentar a emoção que poderiam ter tido!" se assistissem ao "show" desde o início. "Haviam pressentido algo de deslumbrante, mas exaustos [...] não deram importância às corridas que passavam sob as janelas do Hotel Stella Maris." 346

Aquilo que está representado para aqueles hospedados no hotel como um divertimento (acredita-se que assim seja não somente por conta da monotonia que ali se instala, mas também por se considerarem superiores aos negros moçambicanos) remete a um ato de violência muito intensa, um massacre. Evidentemente, estando situado o hotel num território praiano, isolado em uma costa, numa atmosfera de guerra, os habitantes acabam deparando-se com uma visão desprivilegiada por estarem mergulhados num contexto em que a violência e a barbárie imperam. Nesse caso, a abertura da janela, o contato com o exterior, podem indicar, metaforicamente, uma

\footnotetext{
${ }^{343}$ JORGE, Lídia. A costa dos murmúrios. Lisboa: Dom Quixote, 1988, p. 16.

${ }^{344}$ Ibidem, p. 16.

345 Ibidem, p. 18-20.

346 Ibidem, p. 20.
} 
espécie de escuridão e não luminosidade, pois a guerra traz discórdia, desesperança, desilusão.

Em contrapartida, vale lembrar que, no primeiro romance de Lídia Jorge, $O$ dia dos prodígios (1980), como se viu no primeiro capítulo deste trabalho, a janela tem uma conotação de esperança. O olhar através dessa abertura, para Carminha Parda (uma das personagens daquele romance), representa a possibilidade de estabelecer contato com o que está externo ao espaço da casa (vista como espaço de alienação, uma espécie de clausura). Por meio dessa abertura, Carminha vislumbra os transeuntes, a rua, quem entra e sai do vilarejo e, além disso, essa abertura permite o adentramento de uma luminosidade inexistente no interior da casa, além de proporcionar a Carminha uma comunicação com o mundo e, principalmente, consigo mesma. Como se a janela fosse a responsável por trazer vida às mulheres que habitam ali, as Carminhas, mãe e filha.

Esse aspecto esperançoso não vigora quando se observa por meio das janelas ou do terraço do Stella Maris. Parece que há um sentimento de satisfação e também de vingança, como se os portugueses estivessem corretos por invadirem território alheio e como se os negros fossem culpados. Lamentavam os portugueses (talvez os responsáveis pela coleta de lixo) por terem recolhido os corpos dos mortos: "Deviam têlos deixado expostos e apodrecidos à luz do dia, para que se pudesse compreender a nossa causa, a nossa presença, a nossa determinação." ${ }^{347}$

A visão dos portugueses se mostra voltada aos seus interesses de colonizadores e dominadores. Parecem desenvolver uma condição alienada de consciência, que os faz observar somente o que lhes é favorável. Adotam, desse modo, uma postura que violenta os valores do outro (no caso, os negros moçambicanos), invadindo um território que não lhes pertence e devastando-o de uma maneira irreparável. Nesse caso, não se trata apenas da deterioração do espaço físico, mas sim da destruição que rebaixa os negros moçambicanos a uma condição de explorados.

Evidentemente, neste romance, o tema é o da exploração das colônias ultramarinas pelos portugueses. Sabe-se que esse foi um tempo de muita tensão, que durou entre 1961 e 1974. Nesse período, houve uma série de confrontos entre as forças armadas portuguesas e as forças organizadas pelos movimentos de libertação das antigas provícias ultramarinas de Angola, Guiné-Bissau e Moçambique. Tratava-se de uma concorrência desleal porque, além de possuírem mais armamentos que os

${ }^{347}$ JORGE, Lídia. A costa dos murmúrios. Lisboa: Dom Quixote, 1988, p. 20. 
africanos, os portugueses estavam instalados em território alheio e embarcavam em tropas para as terras africanas, a fim de intensificarem os combates e garantirem a tomada definitiva daquelas terras.

Lídia Jorge transfere para a obra essa vivência tal como está registrada na história. Evidencia, no romance, confrontos e massacres que são constantemente vislumbrados pelas personagens através das janelas e varandas do hotel. Na obra, notase também, pelo discurso dos oficiais, grande interesse pela conquista desse território em razão dos benefícios que podem ser extraídos de lá (no que se refere a questões políticas e econômicas) por conta do pouco desenvolvimento urbano, o que se torna um benefício para o lusitano, porque tem maior possibilidade de organizar o território a sua maneira. Outro fator positivo para os lusitanos reside na facilidade de manipulação do povo moçambicano. Um dos capitães dirige a Evita um breve comentário sobre essa questão:

Admire a paisagem, e verá que para ser perfeita, só faltam uns quantos arranha-céus junto à costa. Temos tudo do século dezoito menos o hediondo fisiocratismo, tudo do século dezanove à excepção da libertação dos escravos, e tudo do século vinte à excepção do televisor, esse veneno em forma de écran. Com uns vinte arranhacéus, a costa seria perfeita! $!^{348}$

O discurso do capitão mostra que há, da parte dos portugueses, interesse em conquistar definitivamente o território moçambicano. E isso se daria principalmente porque acreditavam que os africanos eram inferiores, subestimando não somente a capacidade intelectual dos negros como também a habilidade para participarem de uma guerra. Segue outro capitão dizendo:

Pena! [...] ainda era muito cedo para se falar de guerra, que aliás não era guerra, mas apenas uma rebelião de selvagens. Ainda era cedo muito cedo para se falar de selvagens - eles não tinham inventado a roda, nem a escrita, nem o cálculo, nem a narrativa histórica, e agora tinham-lhes dado umas armas para fazerem uma rebelião... ${ }^{349}$

Além disso, os "blackies" se comportavam como se ainda não houvesse ocorrido a libertação dos escravos:

Como se estivesse à espera, um rapaz apareceu munido dum pano, rindo com formidáveis dentes. Aproximou-se, curvou-se e começou a limpar as pernas do noivo cheias de areia e lodo. Esfregava, esfregava,

\footnotetext{
348 JORGE, Lídia. A costa dos murmúrios. Lisboa: Dom Quixote, 1988, p. 12.

${ }^{349}$ Ibidem, p. 13.
} 
mas as manchas resistiam e o noivo ria e então, voluntariamente, o black ajoelhou-se no estrado de pau para limpar um a um os dedos do noivo, e quando terminou, retirou-se de recuo, com o recipiente na mão, rindo intensamente e entornando a água. Tremendo e rindo, desapareceu na porta, fechou a porta. ${ }^{350}$

A atitude do negro demonstra um sentimento de inferioridade em relação ao branco, talvez por sentir-se fragilizado e coagido dentro do seu próprio território (por possuir menos armamentos que os portugueses) e também por estar numa condição de dominado em relação ao dominador. Um dos oficiais, major de dentes amarelos, fez questão de evidenciar que os brancos eram superiores e

com um dragão pintado nas costas, não tinha dúvidas, e lembrava que os povos vencidos por vezes se suicidam colectivamente. [...] E não seria um gesto nobre? Suicidarem-se colectivamente como as baleias, ao saberem que nunca seriam autónomos e independentes? Nunca, nunca, até ao fim da Terra e da bomba nuclear? O major abriu os braços e o dragão desenrugou a potência da sua língua vermelha, pintada. $^{351}$

Esse discurso mostra que, do ponto de vista do oficial, a possibilidade de ascensão dos negros sobre os brancos é praticamente nula, pois os "blackies" são, na visão do major, naturalmente inferiores e incapazes. Além disso, o major demonstra um ar de superioridade, que fica evidenciado na figura do dragão pintado no robe. De acordo com Chevalier e Gheerbrant, a simbologia do dragão pode estar direcionada para o bem ou para o mal. A figura estampada no robe, sendo essa peça de vestimenta de um oficial supostamente de acordo com o tratamento oferecido aos negros, remete à perversidade, e esse "dragão aparece essencialmente como um guardião severo ou como um símbolo do mal e das tendências demoníacas." ${ }^{352}$ Quando o major abre os braços como se pretendesse alçar voo e o dragão "desenrugou a potência de sua língua", o major se mostra como um dragão voador, e esses "são montarias de Imortais; eles os elevam até o Céu" ${ }^{353}$. Esse possível voo garante ainda ao major um ar de superioridade, "porte majestoso do chefe." 354

O dragão também se faz presente no primeiro romance de Lídia Jorge, $O$ dia dos prodígios. A aparição do animal na primeira narrativa não ocorre repentinamente como

\footnotetext{
${ }^{350}$ JORGE, Lídia. A costa dos murmúrios. Lisboa: Dom Quixote, 1988, p. 15.

${ }^{351}$ Ibidem, p. 20.

${ }^{352}$ CHEVALIER, Jean; GHEERBRANT, Alain. Dicionário de símbolos: (mitos, sonhos, costumes, gestos, formas, figuras, cores, números). 19. ed. Rio de Janeiro: José Olympio, 2005, p. 349.

353 JORGE, Lídia. Op. cit. p. 350.

${ }^{354}$ Ibidem, p. 350.
} 
neste quarto romance, mas, lembrando uma cobra com asas, é construído gradativamente pela personagem Branca Volante, em um bordado numa colcha. Aqui, o réptil tem uma conotação positiva, embora apareça também com um ar de superioridade (porque a partir do bordado do animal Branca retoma seu dom de adivinhar e, com isso, mete medo no marido). Depois de recuperado o dom, a personagem começa a perceberse, iniciando, então, um possível processo de conscientização de si. Esses fatores, no caso de uma mulher que se mostrava completamente submissa e retraída, demonstram que, neste caso, o dragão pode representar "uma manifestação da onipotência" ${ }^{355}$, devolvendo à personagem certo poder que talvez ela nem soubesse que possuía.

Em síntese, em $O$ dia dos prodígios, o dragão, como afirmam Chevalier e Gheerbrant, mostra-se com "poder divino [...] símbolo celeste,[...] poder de vida e de manifestação..." ${ }^{356}$. Branca Volante, a personagem que borda o dragão na colcha, demonstrar certo poder após o bordado. Primeiramente, ela começa a adquirir condições para que seus sentimentos aflorem. Esses sentimentos que se manifestam, em primeira instância, parecem vir à tona de maneira involuntária, mas, no decorrer dos acontecimentos, começam a ser controlados, permitindo que Branca comece a colocar em prática principalmente o poder sobre si. Neste caso, a postura dominadora que Branca deixa transparecer, muito provavelmente por influência da figura que se cria no bordado, remete a algo positivo e que certamente contribui para seu autodesenvolvimento.

Já a presença do dragão na vestimenta do major conota uma dominação que se aproveita da fragilidade do outro (os moçambicanos). Vale ressaltar que não se trata de uma fragilidade física, mas sim psicológica, pelo que apresentam os fatos. Eles parecem estar coagidos e praticamente reféns dentro do próprio espaço e também numa posição menos privilegiada em relação aos portugueses, no que se refere a armamentos. Na realidade, os africanos não se mostram preparados para enfrentar e participar igualmente de uma guerra. Os oficiais acreditam, e isso pode ser obervado não somente no discurso do major, mas também no dos outros, que certamente sairão vitoriosos dessa guerra, demonstrando que, para eles, não existe a mínima possibilidade de derrota.

Esse pensamento também passa pela mente das esposas desses servidores da pátria. Certamente porque os pensamentos femininos se mostram como mero reflexo

\footnotetext{
${ }^{355}$ CHEVALIER, Jean; GHEERBRANT, Alain. Dicionário de símbolos: (mitos, sonhos, costumes, gestos, formas, figuras, cores, números). 19. ed. Rio de Janeiro: José Olympio, 2005, p. 350.

${ }^{356}$ Ibidem, p. 350.
} 
dos pensamentos masculinos. Há, portanto, uma força cultural repressora das vontades femininas. Isso se dá em razão da forte repressão às mulheres durante a ditadura salazarista. As portuguesas tinham poucos direitos, estando legalmente dependentes e subservientes ao marido ou ao pai. Consequentemente, elas não tinham voz, sendo, desse modo, excluídas de qualquer participação política.

Com o advento da Guerra Colonial, os jovens filhos e maridos dessas mulheres vão para guerra, na África, e as que ficam no país lusitano acabam ficando sozinhas. Há também aquelas que partem com seus maridos para as colônias e enfrentam também a solidão, porque, assim com as mulheres de A costa dos murmúrios, ficam confinadas aguardando o retorno dos maridos. Nesse cenário em que a ociosidade passa a fazer parte da rotina das mulheres, a propensão a cometer alguns delitos torna-se grande. Mesmo se defrontando com os problemas causados pela Guerra Colonial, grande número das mulheres (aquelas que ficaram sozinhas em Portugal e também as que acompanharam aos seus maridos) sentem-se desorientadas e, enquanto esperam pelo retorno do marido, acabam cometendo traição. No romance, Evita e Helena são exemplos disso.

Exceto Evita, Helena (amiga de Eva e a quem chamam "de Troia"), dentre as mulheres presentes no romance, é a única que recebe um nome, porque as demais são tratadas sempre por referência ao nome de seus maridos. Ela pode ser, juntamente com as outras mulheres, o símbolo da alienação e da subalternidade em relação ao homem. A mulher do capitão Forza Leal

Era uma bela mulher, despida lembrava um pombo, como outras lembram uma rã e outras uma baleia. Não era só a voz que lembrava um pombo, $[\ldots]$ mas era também a perna, o seio, alguma coisa estava espalhada por ela que pertencia à família das colombinas. Talvez o cabelo vermelho, talvez a pele leitosa. ${ }^{357}$

Fazia de tudo para agradar ao marido: "Eles comiam e amontoavam as cascas sobre os pratos, [...] as cascas caíam e Helena apanhava e compunha, como se estivesse ali sobretudo para desempenhar esse papel e sentisse felicidade nesses gestos" ${ }^{358} \mathrm{Seu}$ comportamento assemelhava-se ao de uma mulher da época colonial, que se anulava para servir ao marido e tinha que mostrar satisfação por destinar-se ao outro.

\footnotetext{
${ }^{357}$ JORGE, Lídia. A costa dos murmúrios. Lisboa: Dom Quixote, 1988, p. 68.

${ }^{358}$ Ibidem, p. 72.
} 
A mulher do capitão era brutalizada, maltratada e humilhada pelo marido em todos os aspectos, inclusive em público, diante dos convidados, na festa de Luís e Evita. A justificativa do capitão para o espancamento era o fato de a beleza de sua esposa chamar atenção das pessoas. Evidentemente, com essa atitude, Forza podia demonstrar em público posse e domínio sobre sua mulher, e, com isso, ostentava sua virilidade.

Helena é descrita no romance como despojada de individualidade; dependente do Capitão; privada de profundidade psicológica, "Antes que chore, que derreta a sua inteligência de pombo em gotas de água e cloreto de sódio" ${ }^{359}$; e marcada pela futilidade, "Não - Helena de Troia nesse dia fala do que deveria ter falado desde sempre. Fala de meias, cuecas, langerie. ${ }^{360} \mathrm{O}$ que talvez Helena não soubesse era de certo poder que havia embutido no significado de seu nome.

Lídia Jorge, ao nomear a personagem tal qual a heroína do mito clássico e também por algumas ações da personagem, recupera o mito de Helena de Troia e isso está evidenciado na narrativa por meio da seguinte citação de Homero: "Há mais de vinte cinco séculos, Homero escreveu - Deixai que cada homem marche para a linha da frente - Quer se morra quer se viva. Eis como a guerra e a batalha beijam $e$ murmuram!" - O general espalhou assim os trovões. ${ }^{361}$

A recuperação do mito feita pela autora não está fiel. Vale lembrar que Lídia Jorge deixa transparecer que há uma influência dos clássicos no romance, mas o que parece estar vislumbrado é uma atualização do mito de Helena de Troia, ou seja, ela o mostra de forma subversiva. Os mitos clássicos remetem, por sua essência, ao apogeu de uma época, às grandes epopeias, aos feitos heroicos. Como exemplo disso, pode-se citar Os Lusíadas, grande epopeia portuguesa.

A costa dos murmúrios, em contrapartida, pelos diferentes caminhos percorridos pelas personagens, afirma-se, segundo Santos ${ }^{362}$, como uma antiepopeia. Nota-se isso na fala de Eva Lopo, quando mostra o lado negro do discurso oficial, ao explicar, nas páginas do romance, o que realmente aconteceu no conto Os Gafanhotos. Pode-se afirmar, pelas palavras de Evita, que se tem, na narrativa de $A$ costa dos murmúrios, um lento caminhar do império, mantido por um regime degradado. Confirma-se isso ainda

\footnotetext{
${ }^{359}$ JORGE, Lídia. A costa dos murmúrios. Lisboa: Dom Quixote, 1988, p. 226.

${ }^{360}$ Ibidem, p. 121.

${ }^{361}$ Ibidem, p. 236.

362 SANTOS, Carina Faustino. A Escrita feminina e a guerra colonial. Lisboa: Vega, 2003.
} 
no discurso da esposa de Luís Alex: "Nos regimes como este, mesmo caindo aos pedaços, não se escreve, cifra-se." ${ }^{363}$

A prova dessa decadência está representada pelo Stella Maris, que se transformou num local de resgate de almas viventes, no caso os oficiais:

... o Stella mantinha todo o fragor dum hotel decadente transformado em messe, de belíssimo hall. Era ai, no hall, largo como um recinto de atracagem, $[\ldots]$ que os homens abastados [...] vinham atracar até à década de cinquenta [...] A rebelião ao Norte, porém, tinha obrigado a transformar o Stella em alguma coisa de substancialmente mais prático, ainda que arrebatadoramente mais feia. ${ }^{364}$

Nota-se que a narrativa evidencia um império português em decadência, um espaço degradado e, consequentemente, sem condições de manter a tradição de soberanos, no que se refere aos feitos heroicos. Pelas condições apresentadas, justificase a desmistificação dos mitos, como o de Helena de Troia. Evidentemente, a autora aponta semelhanças entre a Helena jorgiana e a Helena iliádica porque a essência do mito é mantida, mas a primeira ganha uma nova dimensão significativa, decorrente do seu uso na obra de Lídia Jorge.

Uma das semelhanças é a de que ambas as Helenas estão inseridas num contexto de guerra, embora os motivos da guerra, numa leitura mais superficial, pareçam díspares: por um lado, em A costa dos murmúrios, há a luta pela independência de Moçambique e, por outro, a guerra entre gregos e troianos tem como meta o resgate de Helena, raptada por Páris.

Outra similitude entre ambas: assim como a Helena de Troia do mito clássico, a mulher de Forza Leal, bela como jamais vista, provocava sussurros por onde passava. Helena, a do romance, uma figura feminina que chamava atenção pela beleza flamejante dos seus cabelos e se destaca de uma multidão de mulheres morenas e comuns. Helena possui aquilo que se chama uma beleza absoluta e inquestionável, a encarnação do eterno feminino, um tipo que tem tudo para atrair a fatalidade; aos olhos de todos "a mulher mais linda do terraço" 365 .

No mito, Helena aprendeu desde cedo o efeito que sua beleza provocava nos homens e acabou sendo culpada por causar a guerra entre gregos e troianos. No romance, como disse Evita, "Dizer Haec Helena é o mesmo que dizer eis a causa do

\footnotetext{
${ }^{363}$ JORGE, Lídia. A costa dos murmúrios. Lisboa: Dom Quixote, 1988, p. 147.

364 Ibidem, p. 44-5.

365 Ibidem, p. 29.
} 
conflito - gosta?" ${ }^{366}$ Evita explicou-lhe "que era um provérbio antigo, um provérbio que associava o nome de Helena à disputa pela beleza e só valorizava o que era disputado." ${ }^{367}$ Isso mostra que, no mito, a causadora do lendário conflito se apresenta como uma mulher cobiçada e determinada, que abandonou o noivo que seu pai lhe oferecera em casamento para fugir com um troiano, viver uma paixão e se transformar na Helena de Troia, a adúltera, a meretriz. Ao seguir seu coração, a bela moça levou desgraça e ruína a Troia, mas, ainda assim, seguiu seus desejos, em atitude típica de uma heroína.

Na visão de Evita, Helena

poderia ser o corpo que servisse de abstracção, em simultâneo, da Beleza, da Inocência e do Medo, [...] Evita pensou numa divindade a quem se sacrificasse a inocência, e que simbolizasse essas três forças tão precárias e tão violáveis, reunidas. [...] via Helena frágil... ${ }^{368}$

A dependência e fragilidade de Helena eram tão acentuadas que ela tinha esperanças de que a guerra terminasse para não correr riscos de ter o seu marido morto em combate. Por conta da insegurança e por vontade própria, Helena decide dedicar-se, enquanto o marido está na guerra, a uma espera incessante:

A minha alma, eu aprisiono-a aqui, embora não esteja aqui, esteja lá. Sem que ele me tenha pedido sem que ele me tenha dito um som, um aceno de incitamento sequer. Aqui, fechada, privada de liberdade por vontade minha, privada de ar livre por ditame meu. Quero eu mesma fazer a minha prisão! $!^{369}$

Porém, havia uma razão para tal anulação de si mesma. Por ordem do próprio marido, na ausência dele Helena era obrigada a enclausurar-se em casa. Houve um dia em que "ele tinha acendido o isqueiro, e havia começado a passar o dedo pela chama, à espera da promessa dela." ${ }^{370}$ Além disso, a convivência com o capitão em casa parece a simulação de um combate, ele "anda aí agachado entre os móveis, entre os armários [...] sem provocar ruídos, e durante esses dias deixa de falar, encontra-se em silêncio. [...] Viver com um herói é uma aventura muito especial. [...] Pobre do homem que não encontra a companheira do seu combate..." ${ }^{371}$

\footnotetext{
366 JORGE, Lídia. A costa dos murmúrios. Lisboa: Dom Quixote, 1988, p. 72.

367 Ibidem, p. 96.

368 Ibidem, p. 90.

369 Ibidem, p. 97.

370 Ibidem, p. 99.

371 Ibidem, p. 100.
} 
Ao que parece, mesmo vivendo sob tortura, Helena parece estar satisfeita com o seu cotidiano e se orgulha por desempenhar com dedicação o papel de companheira de um capitão. Mas essa vida insípida, solitária, de espera sem retorno, com o passar do tempo, leva Helena à monotonia. Além disso, a prepotência de Forza em face da esposa ("Naturalmente que o capitão reparou nos olhares que choviam como dardos. Naturalmente o capitão esbofeteou a mulher" ${ }^{372}$ ), empurra-a para os braços de um amante. Na visão de Helena, o amante, um despachante,

era um homem bom, era um homem que a amava e ela sabia que a amava porque ela via. [...] Ele era um homem que a entendia e lhe elogiava cada osso, cada músculo, cada forma do seu corpo em movimento. ${ }^{373}$

Helena encontra no amante aquilo que talvez jamais encontrasse no capitão, um amor verdadeiro. O Capitão Jaime Forza Leal descobre a traição. Ele

tinha saltado de dentro do armário, curvado, com o cano à volta, a roupa interior marcada pela passagem do despachante, suspensa da mão, e tinha-lhe colocado a espingarda entre os olhos. [...] A princípio acho que me queria matar, mas depois queria só o nome "Dei o nome, Deus sabe que dei o nome" - disse Helena, cheia de medo. ${ }^{374}$

Forza mata o amante e "Depois os capangas meteram o despachante no nosso bote a motor, e foram despejá-lo no mar" ${ }^{375}$. Helena, em profundo estado de solidão e enclausurada em sua residência por dois meses, sem sequer respirar o ar fora de seu quarto, "só diz o que Evita sabe antecipadamente [...] deseja morrer" ${ }^{376}$ Tem esse desejo porque acredita, a mulher do capitão, que não suportaria o regresso do marido. Afinal, a liberdade e felicidade de Helena pareciam residir na viagem "que ela e o despachante tinham obviamente pensado" ${ }^{377}$ em realizar.

Evita acredita que há, apesar dessa aparente entrega, um desejo, por parte de Helena, de viver. "Morrer significaria ter a coragem de renunciar à imaginação de que se é amado, e Helena não tem coragem" ${ }^{378}$. Mas, ainda assim, Helena prevê o momento em que todos a abandonarão (inclusive empregados, aos quais ela chamava de mainatos) "E que pela janela aberta entram os mosquitos, as formigas, as vorazes

\footnotetext{
372 JORGE, Lídia. A costa dos murmúrios. Lisboa: Dom Quixote, 1988, p. 29.

373 Ibidem, p. 205.

374 Ibidem, p. 206.

375 Ibidem, p. 207.

376 Ibidem, p. 220.

377 Ibidem, p. 205.

378 Ibidem, p. 220.
} 
formigas de África, as baratas voadoras [...] e a chuva de gafanhotos. E cada espécie, a seu modo, com sua espécie de mandíbula, a rata, a engole e devora." ${ }^{379}$

Helena faz uma espécie de premonição, indicando que o fim está-se aproximando. Nesse contexto de desgraça para a personagem, momento em que sua vida se finda, ela percebe não somente o espaço sendo invadido por pragas, mas ainda ela própria sendo devorada por esses insetos. No discurso de Helena, ao mencionar uma invasão de insetos, está evidente uma alusão ao texto bíblico.

No livro de Êxodo (numa conotação negativa), que discorre sobre as dez pragas do Egito, há passagens que mencionam, dentre outras maldições, moscas, morte de animais, sarna, granizo, trevas e também gafanhotos. Esses infortúnios foram lançados sobre os egípcios, depois de o faraó se negar a libertar o povo hebreu da escravidão. No trecho intitulado "Os gafanhotos" (Êx 10: 12-15) O Senhor disse a Moisés:

Estende tua mão sobre o Egito para que venham gafanhotos sobre ele, e invadam o Egito, e devorem toda a erva da terra, [...]13 Moisés estendeu sua vara sobre o Egito, e o Senhor fez soprar sobre o país [...] um vento do oriente. $\mathrm{E}$, chegando a manhã, o vento do oriente tinha trazido os gafanhotos. 14 Espalharam-se eles sobre todo o Egito, e invadiram todo o território egípcio em tão grande quantidade como nunca houve nem haverá jamais invasão semelhante: 15 eles cobriram toda a superfície do solo em todo o país, de modo que a terra se escureceu. Devoraram toda a verdura da terra e todos os frutos das árvores que tinha poupado o granizo. ${ }^{380}$

A passagem, no texto original, remete a uma devastação no Egito, em que a chuva de gafanhotos, assim como uma erva daninha, trouxe desgraça não deixando restar nada do que era verde, nem árvores, nem plantas do campo. Isso ocorre como forma de castigo ao Faraó por se negar a libertar o povo hebreu para ir ao encontro do Senhor.

No livro "Êxodo", no Antigo Testamento, os gafanhotos, assim como outros insetos, simbolizam destruição. Desse ponto de vista, é possível compreender o medo da personagem Helena quando se vê em meio a uma invasão de insetos.

A mulher de Forza Leal demonstra certo pânico porque os insetos parecem representar, aos olhos dela, um suplício, uma tormenta, como descrito no

\footnotetext{
379 JORGE, Lídia. A costa dos murmúrios. Lisboa: Dom Quixote, 1988, p. 221.

${ }^{380}$ BÍBLIA. Português. Bíblia Sagrada. Trad. dos originais Centro Bíblico Católico. 111. ed. São Paulo: Ave-Maria, 1997, p. 110.
} 
"Apocalipse" 381 , em que os gafanhotos tinham poderes semelhantes aos do escorpião da terra. Eles não causavam dano às verduras, mas atormentavam os homens que não seguiam a Deus. "Foi-lhes ordenado que não os matasse, mas os afligissem por cinco meses. Seu tormento era como o da picada do escorpião. Naqueles dias, os homens buscarão a morte e não a conseguirão; desejarão morrer, e a morte fugirá deles." 382

Mesmo com todo o sofrimento e as tormentas que a desestabilizam, Helena, vasculhando os objetos secretos do capitão, acaba descobrindo fotografias que incriminam não somente o Forza Leal como também Luís Alex. Helena conduz Evita até o local:

Helena levou-me atrás de si até o recinto que parecia não fazer parte da casa e que tinha acesso através de um corredor que não dava para outra divisão além daquela. [...] Por dentro das caixas havia envelopes, e dentro dos envelopes, amarradas com elásticos, as fotografias arrumavam-se por operações." 383

Helena apresenta a Evita a verdadeira faceta de Luís Alex, um cruel sanguinário. A mulher do capitão pegou outro pacote que continha uma foto
e mostrou o soldado em pé, sobre o caniço. Via-se nitidamente o pau, a cabeça espetada, mas o soldado que a agitava não era um soldado, era o noivo. Helena de Tróia disse - "Vê aqui o seu noivo?" Ela queria que Evita visse. ${ }^{384}$

A perspectiva da narradora em face do mundo muda diante da revelação de Helena. Evita, a partir de então, inicia-se no mundo real, e a responsável por esse amadurecimento é, sem dúvida, Helena de Troia.

A atitude de Helena mostra que, mesmo aparentemente entregue à clausura e mergulhada na solidão, "qual donzela pura de uma cantiga de amigo que espera leda $e$ triste, na clausura do seu lar, o amado que partiu" ${ }^{385}$, quer que Evita tenha conhecimento sobre a realidade e também parece ansiar pela morte do marido, o que vai de encontro à expectativa, porque o mais comum seria que ela esperasse pelo regresso e não por uma tragédia, o que, para ela, seria uma solução. De fato, o sacrifício de Helena é para que

\footnotetext{
381 Apocalipse, 9: 3-6. In: BÍBLIA. Português. Bíblia Sagrada. Trad. dos originais Centro Bíblico Católico. 111. ed. São Paulo: Ave-Maria, 1997.

${ }^{382}$ Ibidem, p. 1564.

383 JORGE, Lídia. A costa dos murmúrios. Lisboa: Dom Quixote, 1988, p. 129-131.

${ }^{384}$ Ibidem, p. 133.

385 SANTOS, Carina Faustino. A Escrita feminina e a guerra colonial. Lisboa: Vega, 2003, p. 45.
} 
"aconteça alguma coisa em Cabo Delgado! [...] É aí que ela quer, e sempre quis, que rebente uma mina debaixo dos pés de Forza Leal tão explosiva que o deixe desfeito" ${ }^{386}$

Helena deseja sua emancipação, mas não consegue ter força para seguir o caminho da liberdade: "Ora eu devia ter saído, mas não era capaz de me mover daqui, enquanto as portas batiam." ${ }^{387}$ Havia uma dificuldade muito grande, não somente em Helena, mas em todas as mulheres que estavam na mesma situação, para se libertar da opressão. Se a esposa de Forza tivesse seguido seus impulsos, talvez não tivesse conseguido exercer sua liberdade plena. Primeiramente porque estava em território estranho e, principalmente, porque a imagem da mulher obediente estava tão enraizada no íntimo feminino que era muito difícil se desvencilhar desse estigma. Ainda assim, Helena teve a oportunidade de ao menos almejar a liberdade e, o que foi benéfico para Evita, conseguiu alertar a esposa de Luís Alex.

Desse modo, é possível perceber que Lídia Jorge analisa, neste romance, sobretudo a sujeição, a impotência da mulher enquanto enquadrada no regime do Estado Novo. Para isso, a autora utiliza a figura das mulheres que aparecem no romance sem identidade, porque não são nomeadas, e a de Helena, que se destaca por seu aspecto surpreendente.

Sabe-se que, naquele contexto (de guerra colonial, em território alheio, à mercê do retorno de seus maridos da guerra), uma possível reação ou qualquer atitude de rebeldia poderia custar, muitas vezes, a própria vida. Por conta disso, talvez fossem forçadas, aquelas mulheres, a manter-se naquela situação. Além disso, eram educadas para serem servis. Helena, por exemplo, fora educada num colégio de freiras e, desde cedo, submetida a uma educação com muitas normas e regras, até na forma de vestir, que não condiziam com sua verdadeira personalidade e com o desejo de livre expressão da própria feminilidade e sensualidade.

Este conflito acaba sendo perceptível a partir do esforço que Helena faz para ser "obediente". Na realidade, percebe-se que essa atitude de aparente passividade que emerge de Helena e também das outras mulheres pode ser resultado de pressões externas que levam essas mulheres a tornarem-se a sombra dos seus maridos. Evidentemente, se não cumprissem os deveres impostos pela sociedade da época, essas mulheres não seriam aceitas. No que se refere a Helena, até mesmo o seu pensamento crítico estava condicionado a repetir, constantemente, o discurso do marido. Essa atitude

\footnotetext{
${ }^{386}$ JORGE, Lídia. A costa dos murmúrios. Lisboa: Dom Quixote, 1988, p. 200-201.

${ }^{387}$ Ibidem, p. 206.
} 
evidenciava com maior intensidade a condição de inferioridade de Helena e outras mulheres.

Mas é possível crer que, mesmo camuflada, haja, no íntimo delas, uma força propulsora da esperança. Sendo assim, "o fio de sangue que ressumava da orelha" ${ }^{388}$, "os vergões" ${ }^{389}$, "os cinco dedos esculpidos na face" ${ }^{390}$ (a olho nu, símbolo de sofrimento) representados no trecho descrito pela cor vermelha (símbolo fundamental do princípio de vida), atrelados ao "verde-limo da luz" ${ }^{391}$ que exalava dos gafanhotos, podem ter contribuído para o início de um despertar.

No conto intitulado Os gafanhotos (insetos que são caracterizados no próprio texto com um verdejar reluzente, simbolizando um novo despertar de esperança) se mostra, como já dito, uma alusão ao texto bíblico, mas há também, diferentemente da visão de Helena de Troia, uma visão positiva. A nuvem de gafanhotos talvez não represente a multiplicação devastadora, a imagem da praga, como no Antigo Testamento, e o suplício de ordem moral e espiritual, como citado no Novo Testamento.

Esse episódio do surgimento dos gafanhotos, na narrativa da autora portuguesa, pode remeter a uma espécie de renascimento. Parece que aquele "espetáculo" descortina, para as personagens que o presenciam, "um novo horizonte. Pelas características desse inseto, sabe-se que se pode apresentar nas cores marrom claro e verde, porém, no texto de Lídia, quando se retrata a nuvem de insetos que adentra a costa, o verde luminoso é intensificado e, pelo que parece, a partir daí uma espécie de crença no que está por vir, com uma perspectiva positiva, começa a se instalar no cotidiano do Stella Maris, como se um fio de esperança adentrasse os corações das personagens.

O comportamento que deixam transparecer diante da nuvem de ortópteros revela o sentimento das personagens. Eva Lopo, a protagonista, descreve a chegada dos insetos como se trouxessem com eles a esperança de um novo tempo: "Lindos, brilhantes, fosforescentemente verdes, rondavam perto das lâmpadas que iluminava as portas." ${ }^{392}$ Essa luminosidade excessiva talvez pudesse representar o fim da escuridão, dos tempos da guerra que causou destruição e desgraça. Não somente Evita, mas todos vão até a

\footnotetext{
388 JORGE, Lídia. A costa dos murmúrios. Lisboa: Dom Quixote, 1988, p. 32-33.

${ }^{389}$ Ibidem, p. 32-33.

390 Ibidem, p. 32-33.

391 Ibidem, p. 32-33.

392 Ibidem, p. 212.
} 
varanda para ver o espetáculo. "Não estavam contudo os homens mais moços" ${ }^{393}$ porque provavelmente estavam em guerra. Até as mulheres que sempre ficavam reclusas

Resolveram deixar as arcadas de onde viam a noite entre todo aquele rumor formal e quase culto, para poderem passear à chuva. Elas subiram aos quartos para buscar protecção, e desceram convenientemente calçadas e munida de abrigos ligeiros, próprios para os climas tropicais. Atravessaram o hall, atingiram a marginal e puseram-se a passear sobre o paredão, de guarda-chuvas abertos. ${ }^{394}$

Viam-se de longe, como se lê na narrativa, aquelas mulheres à luz das lâmpadas verdes, e caindo sobre os guarda-chuvas gotas de gafanhotos voando. Esse "deve ter sido o dia mais interessante das suas domésticas vidas." ${ }^{395}$

Essas jovens eram mulheres de alferes milicianos (universitários de boa família e de boa formação acadêmica, convocados para a guerra), verdadeiros corpos solitários. Geralmente confinadas a espaços exíguos (pequenos quartos, varandas, salas, halls de hotéis), somente lhes era permitido empreender uma viagem interior e descortinar os bastidores da guerra. Pelo fato de não participarem das operações que combatiam a guerrilha no mato, ficavam na "retaguarda" e só pela voz oficial do Império assimilavam a verdadeira essência da operação camuflada.

Já na epígrafe de Álvaro Sabino (personagem-autor) nota-se que a chuva de gafanhotos parece algo imageticamente bonito, que remete à esperança. Ele se refere aos gafanhotos como "esmeraldas voadoras" 396 e descreve o momento em que os insetos invadiram a costa da seguinte forma: "O céu incendiou-se de verde onde nem era necessário - todas as fogueiras da costa tomaram essa cor, mesmo as que inchavam nos nossos corações." ${ }^{397}$ Considerando a epígrafe como uma inscrição que pretende situar a motivação da obra, é possível verificar, por meio dela, que Lídia Jorge se apropria dessas narrativas matriciais de maneira diferente, atribuindo-lhe um sentido próprio. Aquilo que se mostra devastador nos textos bíblicos (terríveis tempestades de granizo que caíram sobre o Egito, e por anomalias climáticas que teriam resultado em precipitações mais constantes, criando um ambiente propício para a chegada de gafanhotos) parece, no conto, apresentar outra conotação.

No momento da invasão dos gafanhotos,

\footnotetext{
393 JORGE, Lídia. A costa dos murmúrios. Lisboa: Dom Quixote, 1988, p. 217.

${ }^{394}$ Ibidem, p. 217.

395 Ibidem, p. 218.

396 Ibidem, p. 09.

${ }^{397}$ Ibidem, p. 09.
} 
o verde-limo da luz era tão vivo que conseguia anular os objectos vermelhos do terraço. [...] o fio de sangue que ressumava da orelha daquela rapariga batida pelo marido [...] Sobretudo os vergões que muitas delas tinham pela cara. Os cinco dedos da mão de Forza Leal ainda estariam visíveis como se esculpidos na face esquerda de Helena de Tróia ... ${ }^{398}$

Tudo isso era vermelho. A nuvem intensa de gafanhotos que sobrevoou o Stella Maris transformou o ambiente e também as pessoas que ali estavam. Sendo assim, de acordo com Chevalier, "o verde é o despertar da vida. [...] É a cor da imortalidade universalmente simbolizada pelos ramos verdes." ${ }^{399}$ Além disso, ainda segundo o estudioso, o verde entra com o vermelho num jogo simbólico de alternâncias, porque a rosa vermelha desabrocha entre folhas verdes. Sendo assim, "O desencadear da vida parte do vermelho e desabrocha no verde." ${ }^{400} \mathrm{O}$ verdejar dos gafanhotos, em concomitância com a vermelhidão que se instalava no hotel Stella Maris, em princípio símbolo do sofrimento e da condição inferiorizada daquelas mulheres em relação aos seus maridos, parece encorajá-las.

Chevalier atribui à cor vermelha (cor de fogo e de sangue) o símbolo de uma força imensa e irredutível. Ao contrário disso, o vermelho escuro "é noturno, fêmea, secreto [...] representa não a expressão, mas o mistério da vida." ${ }^{401}$ De certa forma, parecia haver algo de misterioso no comportamento daquelas mulheres. Eram gratuitamente espancadas e reduzidas ao nada, não tinham voz, não eram respeitadas, desprovidas de qualquer direito que promovesse sua autoconstrução e, ainda assim, continuavam sujeitando-se aos maus-tratos. Como já mencionado, havia uma força propulsora, a voz da mentalidade patriarcal, coagindo-as e com um poder intenso de dominação, intimidando qualquer atitude de transgressão das mulheres. Mas, ainda assim, é possível perceber, por meio de Helena de Troia e, principalmente, de Eva Lopo, que há possibilidade de emancipação.

Lídia Jorge mostra, ao longo da narrativa, que é possível subverter, pela maneira como apresenta o mito de Helena de Troia, de forma inversa, e também quando se apropria da narrativa matricial (o texto bíblico). Pode-se dizer que a autora parodia o texto bíblico e isso é evidenciado logo na epígrafe, como já comentado. A paródia,

\footnotetext{
398 JORGE, Lídia. A costa dos murmúrios. Lisboa: Dom Quixote, 1988, p. 32-33.

399 CHEVALIER, Jean; GHEERBRANT, Alain. Dicionário de símbolos: (mitos, sonhos, costumes, gestos, formas, figuras, cores, números). 19. ed. Rio de Janeiro: José Olympio, 2005, p. 939.

400 Ibidem, p. 939.

401 Ibidem, p. 944.
} 
assim como a ironia, afirma Hutcheon em Uma teoria da paródia, "tornam-se os meios mais importantes de criar novos níveis de sentido. ${ }^{402}$

A maioria dos teóricos da paródia remonta a raiz etimológica do termo ao substantivo grego parodia, que quer dizer "contracanto", e acabam se restringindo a isso. No entanto, podem-se obter, por meio dessa raiz, outras informações. A natureza textual ou discursiva da paródia (por oposição à sátira), ainda de acordo com Hutcheon, é evidente no elemento odos da palavra, que significa canto. O prefixo para apresenta dois significados, sendo geralmente mencionado apenas um deles - o de "contra" ou "oposição". Sendo assim, "a paródia torna-se uma oposição ou contraste entre textos." 403 Neste caso, um texto é confrontado com outro, com a intenção de zombar dele ou de o tornar caricato.

Por outro lado, esse mesmo termo para, em grego, também pode significar, como ressaltou Hutcheon, "ao longo de", e este segundo sentido, esquecido do prefixo que alarga, "o escopo pragmático da paródia de modo muito útil para as discussões das formas de arte modernas" 404 , parece se enquadrar melhor. Isso mostra que o conceito de ridículo não precisa necessariamente ser inserido na paródia; o caráter duplo do sentido da raiz da palavra pode sugerir a discussão de termos mais neutros. Sendo assim,

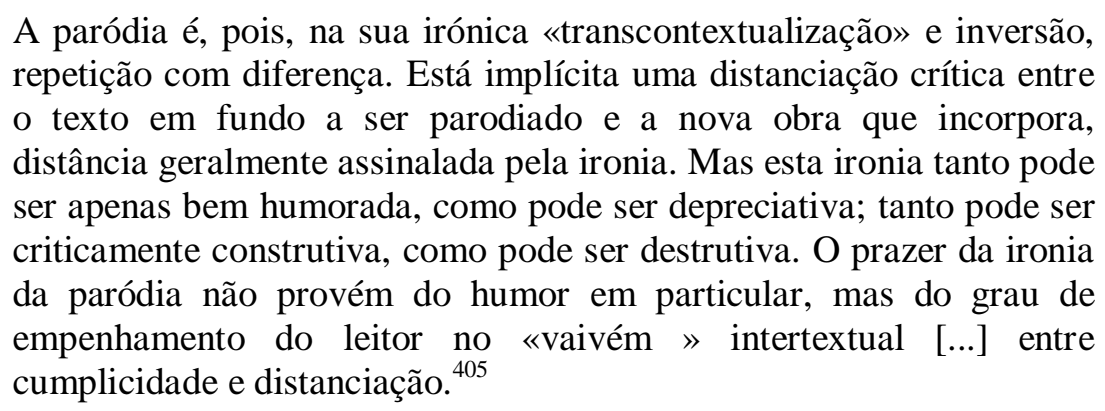

O recurso paródico presente na narrativa de Lídia Jorge parece enquadrar-se no segundo sentido. A autora se vale de trechos do livro sagrado e faz uma espécie de remontagem. Nota-se, como já citado, que Jorge expõe, na narrativa em questão, "uma repetição" do texto bíblico, porém "com diferença".

Talvez essa movimentação que a autora faz no texto "remontado" possa ocasionar certa mudança no comportamento das personagens. Percebe-se, por meio da

\footnotetext{
${ }^{402}$ HUTCHEON, Linda. Uma teoria da paródia. Trad. Teresa Louro Pérez. Lisboa: Edições 70, 1985, p. 46.

${ }^{403}$ Ibidem, p. 47-48.

${ }^{404}$ Ibidem, p. 48.

${ }^{405}$ Ibidem, p. 48
} 
atitude das mulheres (ultrapassar os limites do espaço delimitado do hotel para usufruírem e vivenciarem a "chuva de gafanhotos"), uma mudança de comportamento jamais esperada, porque, para qualquer movimentação, tinham que pedir permissão aos seus maridos. Parece que agiram por impulso, sem pensar nas consequências que aquele ato poderia causar. Essa pode ter sido uma maneira, de certa forma, de quebrarem o silêncio. Até então, apresentavam-se totalmente à margem da história oficial, porque, na visão salazarista, as mulheres não integravam a história. Com essa postura, parecem, as jovens senhoras, querer legitimar um lugar no mundo, muito provavelmente sem terem consciência exata de suas ações.

Eva Lopo talvez seja a única personagem no romance a demonstrar que é necessário deixar emergir, mesmo estando inserida nesse contexto repressor e propenso à alienação, uma voz que antes estava silenciada. Assim como as outras, Eva/Evita também vivia pressionada pela carga negativa imposta às mulheres, mas a narrativa leva a crer que há possibilidade de transgressão.

A protagonista de $A$ costa de murmúrios parece ser exceção em relação às demais mulheres do romance. Isso se evidencia em seu nome, que traz em si certa carga de poder, por pertencer a uma personagem bíblica e, principalmente, pelo significado do nome: "aquela que tem vida". Retratada, no livro de Gênesis, no Antigo Testamento, como a primeira mulher da humanidade, criada por Deus a partir da costela de Adão para preencher sua solidão, Eva vivia com Adão no Jardim do Éden, foi enganada pela serpente e acabou por comer o fruto proibido, dando-o também a Adão, o que resultou na expulsão de ambos do "Paraíso" e no surgimento do sofrimento humano. Furioso com a desobediência do casal, o Senhor, no Gênesis ${ }^{406}$, dá-lhes o veredito:

Multiplicarei os sofrimentos de teu parto; darás à luz com dores, teus desejos te impelirão para o teu marido e tu estarás sob o seu domínio E disse em seguida ao homem: [...] maldita seja a terra por tua causa. Tirarás dela com trabalhos penosos o teu sustento todos os dias de tua vida. Ela te produzirá espinhos e abrolhos, e tu comerás a erva da terra. Comerás o teu pão com o suor do teu rosto... ${ }^{407}$

Se Eva não tivesse dado ouvidos à serpente, a profecia não se teria cumprido. Sendo assim, esse nome pode ter uma conotação, aos olhos de muitos, um pouco

\footnotetext{
${ }^{406}$ Gen. 3:16-19. In: Bíblia Sagrada. 111. ed. São Paulo: Ave-Maria, 1997.

${ }^{407}$ Ibidem. p. 51.
} 
negativa, mas também acredita-se que possa ser atribuído a ele um tom de superioridade, exatamente por ser Eva a progenitora da humanidade.

Em A costa dos murmúrios, Helena, a dada altura, desempenha o papel da serpente que irá expulsar Eva do seu paraíso genesíaco, obrigando-a a enxergar a realidade. Isso ocorre quando lhe mostra um conjunto de fotografias que expõem as atrocidades nas quais participou Luís Alex durante o ataque a uma aldeia. Helena exerce o papel da mensageira que abre a porta para o conhecimento à até então inocente Evita.

Eva se mostra também uma mulher lúcida, mais esclarecida e racional que Helena (por apresentar uma significativa capacidade dedutiva e um conhecimento histórico que lhe permitiu desenvolver o pensamento crítico, já que teve acesso à universidade e adquiriu o hábito de colocar questões incômodas).

Dotada de uma percepção muito aguçada e de uma curiosidade insaciável, Eva/Evita foi capaz de desvendar o crime que intrigava as consciências coletivas dos habitantes da Costa. Ela descobre, antes de todos e juntamente com o jornalista da gazeta local, que os negros estavam sendo mortos. Sob esse prisma, esses acontecimentos (mesmo terríveis e demonstrando falta de humanismo por parte do colonizador) talvez possam ser considerados benéficos para o desenvolvimento da consciência de Evita, pois há indícios de que, ao descobrir a tragédia e a causa dela, a noiva de Luiz Alex inicia o processo de conscientização sobre os fatos que a rodeiam (que mostram o papel de dominador que o português exerce) e, consequentemente, sobre si mesma.

Isso faz crer que, paralelamente ao universo masculino e militar o mundo de Eva, ao contrário do universo das outras mulheres, não se reduz a maternais consolos a dar a homens embrutecidos pela guerra ou ainda a embelezar as festas do hotel Stella Maris. O espaço de Evita, neste mundo imperial crepuscular, vai-se, antes, definindo pela interrogação constante das atitudes daquela sociedade degradada e degradante.

Desse modo, Eva apresenta uma visão ampliada dos fatos. Isso se processa porque vivenciou os acontecimentos dos últimos anos da Guerra Colonial em Moçambique a partir de um ângulo diferente. Por esse motivo, parece apresentar uma imagem que se afasta da oficial, fator que pode implicar uma revisão da história.

Pode-se considerar que o discurso oficial está inserido na primeira parte do romance (no conto Os gafanhotos). Essa primeira parte, em que os fatos são apresentados sob a perspectiva do colonizador, ou seja, dos soldados, capitães e seus acompanhantes, mostra como os colonizadores vivem num mundo idealizado, 
mantendo-se afastados dos acontecimentos reais, que apenas vislumbram à distância. $\mathrm{O}$ distanciamento entre o mundo real e a realidade construída pelos oficiais é simbolicamente materializado pelo espaço isolado, lugar em que é realizada a cerimônia do casamento de Luís e Eva, no terraço do hotel, onde o contato com o externo ao hotel é dificultado e de onde só é possível ter uma visão distorcida e distante da realidade.

A segunda parte da narrativa, sequência da obra, desvela a aparente harmonia instaurada no conto:

Os noticiários omitiam e a maior parte das mulheres que falavam no terraço concordava com a omissão. Era uma questão de justiça - se se omitia a morte e o sofrimento dos soldados portugueses atingidos em combate, por que razão se haveria de alarmar as pessoas mais sensíveis com a notícia da morte voluntária de uns negros ávidos de álcool? Se morriam, morriam. ${ }^{408}$

Estes fatos relembrados vinte anos mais tarde por Eva Lopo desencadeiam um processo de revelação. O narrador-personagem, Evita, se mostra agredido pelo opressor, que vem mostrar a violência usada na repressão contra os moçambicanos, o que a leva a transgredir, a trair o texto primeiro em busca da verdade. Nessa busca, como já foi mencionado, verifica-se uma duplicidade na estrutura narrativa, primeira parte conto e segunda, romance.

$\mathrm{Na}$ primeira parte da narrativa, como já dito, está a história oficial, os colonizadores como heróis. Na segunda, ocorre uma nova imagem da história, pelo fato de a guerra ser perspectivada a partir da visão feminina, a partir daquelas que ficam na retaguarda, como disse Santos, "[n]o espaço de uma vida doméstica" ${ }^{409}$, enquanto os maridos estão em combate, no "amplo espaço do mato". ${ }^{410}$

Bakhtin, em A teoria do romance 411 , afirma que "O gênero é, para ele, um raio X de uma visão de mundo específica, uma cristalização dos conceitos peculiares a um dado tempo e a um dado estrato social em uma sociedade determinada." ${ }^{412}$ Eva, de fato, apresenta sobre os acontecimentos que envolvem a Guerra Colonial, uma visão específica e bem diferente das atitudes dos oficiais, dos ideais da guerra e do comportamento alienado das mulheres com quem convive. Isso sugere à protagonista a

\footnotetext{
${ }^{408}$ JORGE, Lídia. A costa dos murmúrios. Lisboa: Dom Quixote, 1988, p. 62.

${ }^{409}$ SANTOS, Carina Faustino. A escrita feminina e a guerra colonial. Lisboa: Vega, 2003, p. 33.

${ }^{410}$ Ibidem, p. 33.

${ }^{411}$ BAKHTIN, Mikhail. A teoria do romance. In: CLARK, Katerina; HOLQUIST, Michael. Mikhail Bakhtin. São Paulo: Perspectiva, 1998.

${ }^{412}$ Ibidem, p. 293.
} 
revisão de seus próprios conceitos, colocando em xeque tudo o que antes acreditava ser verdade.

A noiva de Luís Alex se mostra, no romance, com uma força e uma ânsia por investigar os fatos que antes, no conto, pareciam não existir. A Evita d'Os Gafanhotos parecia frágil e disposta a se casar e, talvez se tornar como as outras mulheres. $\mathrm{O}$ próprio gênero romance, aos olhos de Bakhtin, não é um gênero como qualquer outro, sugere "um tipo especial de força, que ele chama 'romancidade ${ }^{\prime 413}$ Diante disso, a voz que está por trás da narrativa, por meio da personagem Eva Lopo (identificada no romance - já na sua fase adulta e mais experiente por nome e sobrenome e não mais por um apelido, Evita, - no diminutivo que pode remeter não somente à imaturidade como também à fragilidade), parece se valer da chamada "romancidade" exposta pelo teórico russo.

Essa voz que emerge da narrativa podendo sugerir um autor implícito ou até mesmo a própria Lídia Jorge, apresenta, de fato, Eva Lopo, como uma mulher dotada de certa força e, sobretudo, de coragem a ponto de explicitar, de forma destemida, os reais acontecimentos. A ""romancidade" pode operar de modo a minar a cultura oficial ou alta de qualquer sociedade" ${ }^{414}$, assim como acontece em $A$ costa dos murmúrios. Essa voz, afigurada por Eva, não só tem a intenção de "minar a cultura oficial", como também pretende desconstruir um discurso oficial, que era antes considerado como a verdade absoluta.

Isso ocorre por meio da voz (da protagonista) que emerge exatamente do romance, que é caracterizado por Bakhtin não como sistemas literários compostos por cânones, como comunmente são compostos os outros gêneros, mas

o romance é fundamentalmente anticanônico. Ele não permite o monólogo genérico. Insiste em um diálogo entre os textos que um dado sistema admite como literatura e os que estão excluídos de semelhante definição. ${ }^{415}$

Sendo assim, as ideias expostas na segunda parte do texto estabelecem diálogo com o conto, fazendo suas pertinentes considerações.

Ao estabelecer (de forma ficcionalizada) esse diálogo, vinte anos mais tarde, a noiva do alferes tem como referência o espaço em que se situava (num ambiente que

${ }^{413}$ BAKHTIN, Mikhail. A teoria do romance. In: CLARK, Katerina; HOLQUIST, Michael. Mikhail Bakhtin. São Paulo: Perspectiva, 1998, p. 294.

414 Ibidem.

415 Ibidem. 
não é de guerra - pelo menos não aparentemente - e sem os artefatos que lembram guerrilha; no país de origem, no caso Portugal, e não em território alheio e em terras estranhas, Moçambique; e num espaço que pode expor suas ideias sem que se sinta coagida pela repressão causada pela ditadura).

Passados vinte anos do fim da Guerra Colonial, num fluxo de consciência, Eva revisita o passado e deixa vir à tona o que realmente ocorreu. Nota-se que a protagonista não somente apresenta os fatos como também tenta explicá-los, sugerindo uma evolução textual, e, consequentemente, os fatos são constatados através da participação de outros personagens, como, por exemplo, o jornalista Álvaro Sabino (com quem Evita tem um caso e com quem se encontra nas ausências do noivo).

Para o teórico russo, o romance "proporciona diferentes pontos de referência a partir dos quais é dado mapear uma história da consciência." ${ }^{416}$ Em se tratando de Eva, parece que ela fez uma mapeamento de sua consciência para expor os acontecimentos de duas décadas passadas. Além disso, verifica-se que, devido ao contato com a universidade e devido a seu senso investigativo, Eva parece ter desenvolvido uma consciência histórica que lhe possibilitou uma revisita, com um olhar crítico, à época da Guerra Colonial. Sendo assim, a autora do romance, elegeu o gênero romanesco para que a personagem pudesse expor seus anseios por meio de uma voz até então silenciada, que não encontrava possibilidades para se expor.

Além disso, Bakhtin destacou duas variáveis principais e básicas na evolução do romance e também da consciência: "atitudes para com o tempo e o espaço" ${ }^{417}$. Vale dizer que, para considerar a importância dessas categorias, Bakhtin apoiou-se, sobretudo, em Emmanuel Kant e nos neokantianos. Esses pensadores consideram que os mecanismos pelos quais a mente organiza as experiências são provenientes das duas categorias (tempo e espaço).

Convém observar que, como Kant discutiu em Crítica da razão pura ${ }^{418}$, talvez espaço e tempo não sejam qualificados como "categorias" de intelecção e sim como "formas" de percepção. Sendo assim, para o filósofo, o espaço

não é mais do que a forma dos fenômenos dos sentidos externos [...] Nosso exame do espaço mostra-nos a sua realidade, quer dizer, o seu

\footnotetext{
416 BAKHTIN, Mikhail. A teoria do romance. In: CLARK, Katerina; HOLQUIST, Michael. Mikhail Bakhtin. São Paulo: Perspectiva, 1998, p. 295.

417 Ibidem.

${ }^{418}$ KANT, Emmanuel. Crítica da Razão Pura. Trad. J. Rodrigues de Merege. Versão eletrônica da obra, pesquisada em: 31/12/2014. http://www.dominiopublico.gov.br/download/texto/cv000016.pdf
} 
valor objetivo relativamente a tudo aquilo que se pode apresentar-nos como objeto; ${ }^{419}$

e o tempo

é a forma do sentido interno, que quer dizer, da intuição de nós outros mesmos e de nosso estado interior. O tempo não pode ser determinação alguma dos fenômenos externos, não pertence nem a uma figura, nem a uma posição, pois ele determina a relação das representações em nossos estados internos. ${ }^{420}$

Evita / Eva, ao descrever com minúcias os acontecimentos no conto, parece se valer, de forma intuitiva, do tempo e do espaço para relatar as experiências vividas. Ao pormenorizar os espaços do hotel Stella Maris e os acontecimentos na praia de Mueda, no entorno no hotel, a protagonista apresenta os fatos com veracidade, com o intuito de nos aproximar ao máximo daquela realidade e, sobretudo, para mostrar suas impressões sobre aquele espaço interno. Quanto ao tempo, por representar uma "forma de sentido interno", Eva, situada em 1988, vai buscar no seu interior o que ocorrera em 1968. Como se ela organizasse, internamente, os acontecimentos de duas décadas anteriores (sob nova perspectiva, crítica e compromissada com a verdade).

Pelo que se nota, essas duas formas de percepção estão fundadas no $\operatorname{self}^{421} \mathrm{e}$ parecem enfatizar o quanto são significativas na experiência real. Para melhor representar essas categorias, Bakhtin introduziu o termo "cronótopo". "A palavra quer dizer literalmente tempo/espaço e, no uso feito por Bakhtin, é uma unidade para estudar textos em conformidade com a razão e a natureza das categorias temporais e espaciais representadas." 422

Em A costa dos murmúrios, o cronótopo é o conceito que permite ao leitor identificar o raio X que Eva Lopo, em sua fase adulta, faz da época em que ocorreu seu noivado. Também permite reconhecer o intuito de aproximar-se da realidade, mantendo fidelidade aos fatos narrados. De fato, o tempo e o espaço são categorias primárias de percepção fundamentais e as formas mais imediatas e eficazes de estar em contato com o mundo real.

\footnotetext{
${ }^{419}$ KANT, Emmanuel. Crítica da Razão Pura. Trad. J. Rodrigues de Merege. Versão eletrônica da obra, pesquisada em: 31/12/2014. http://www.dominiopublico.gov.br/download/texto/cv000016.pdf, p. 18-19. ${ }^{420}$ Ibidem, p. 21.

${ }^{421}$ Outro termo utilizado por Bakhtin em A arquitetônica da respondibilidade.

${ }^{422}$ BAKHTIN, Mikhail. A teoria do romance. In: CLARK, Katerina; HOLQUIST, Michael. Mikhail Bakhtin. São Paulo: Perspectiva, 1998, p. 296.
} 
Bakhtin explica a necessidade de apropriação do "cronótopo" ao expor, no romance, as experiências vividas, porque

o nosso senso totalmente integrado de espaço e tempo molda o nosso senso de realidade. Nós estamos constantemente empenhados na atividade de re-presentar os sinais que recebemos de nosso ambiente exterior, mondando-os em um padrão por meio de cronótopos particulares. ${ }^{423}$

Parece não haver, de acordo com o teórico russo, a possibilidade de desvencilhar a realidade das categorias tempo e espaço, pois os dois têm certo grau de importância.

No romance de Lídia Jorge, o "cronótopo" permite estabelecer uma ponte entre os dois mundos (um, onde Evita vive sua juventude, e outro, onde se situa Eva na sua maturidade). Parece que são dois mundos paralelos, mas ambos se completam. Isso ocorre pelo fato de haver uma relação muito significativa entre o conto e o romance.

Na narrativa em questão, acredita-se que não seria possível a revisitação crítica de Eva a um tempo passado se o texto não estivesse dissociado. Se o enunciado da autora algarvia estivesse apresentado em uma única narrativa, somente romance, sem a presença do conto, por exemplo, seria difícil estabelecer um contraste entre a suposta ficção e o real. Nesse caso, a presença dos dois gêneros se faz importante. Por mais que haja certa resistência entre a fusão do mundo real com o representado, eles se apresentam indissoluvelmente ligados um ao outro.

Eva só consegue perceber, no presente, as falhas e a crueldade que envolvem o comportamento dos colonizadores durante a Guerra Colonial porque vivenciou a guerra, estava presente naquele contexto de crueldade e repressão. Nesse caso, há uma interação entre os dois momentos, com uma troca ininterrupta desenvolvendo-se entre eles. Mas, ainda assim, é possível considerar que, na história de Lídia Jorge, o romance (segunda parte da exibição textual) pode ser considerado, neste caso, como o gênero da maturidade.

Esse momento da narrativa, considerando Eva Lopo responsável pela enunciação da maior parte do romance, parece sugerir o nascimento da consciência da protagonista. Isso pode ocorrer, sobretudo, devido ao olhar feminino que a noiva de Luís Alex lança sobre a guerra colonial, olhar específico que oferece outra perspectiva. Ela tece uma análise detalhada do interior dos espaços, dos tempos (o que Bakhtin

\footnotetext{
${ }^{423}$ BAKHTIN, Mikhail. A teoria do romance. In: CLARK, Katerina; HOLQUIST, Michael. Mikhail Bakhtin. São Paulo: Perspectiva, 1998, p. 297.
} 
chama, como já foi mencionado, de "cronótopo"), dos homens e das mulheres da sociedade que desfilam no hotel. A protagonista questiona o sentido e o resultado das missões militares, além daquela sociedade que ela vê de uma margem, mas na qual, pelas circunstâncias da história, também está inserida.

Embora Evita/Eva esteja inserida naquele contexto, parece, de fato, que está passando por uma fase de amadurecimento, pois seu relato é apresentado como um discurso provocador. Sob esse prisma, a problemática da Guerra Colonial sugere questionamentos acerca da história oficial, sendo possível perceber, pronunciar e interpretar o mundo de um certo ponto de vista, mesmo que este não seja linear (como um "eu" fragmentado ou em processo de (re) construção).

Observa-se, na narrativa, a descrição de um momento de ruptura associado à experiência da Guerra Colonial, relatado por essa jovem universitária que perde o marido-soldado e não está disposta a perder, ao contrário dele (pelo menos aparentemente), seus valores e convicções. Eva/Evita, ao vivenciar o relato de $O s$ Gafanhotos, se depara com uma atitude tradicional perante a guerra, que, ao servir de pano de fundo, pode ser assumida como normal. Nesse relato, o ponto de vista em vigor é efetivamente o do opressor.

Ao adentrar a história de Os Gafanhotos, a imagem da guerra, sob uma perspectiva que se afasta da veiculada pelo homem colonizador, ou seja, tendo em vista o olhar feminino, parece decepcionar. Pelo que mostra a narrativa, talvez seja difícil entender a guerra, porque esta se apresenta como motivo primeiro de desilusão, colocando em xeque as convicções de Eva. À medida que Eva Lopo amplia o seu conhecimento sobre as razões e as ações da guerra, vê diluir-se a fronteira entre o bem e o mal, percebe que o mundo idealizado caminha para a destruição, simbolizada pela transformação de Luís Alex (o antigo estudante de matemática e fiel seguidor e praticante fervoroso do discurso, ideologia e prática colonialista) em "Luís Galex"

Essa nova conotação atribuída ao noivo acarreta o fracasso da relação amorosa, funcionando este como resultado e símbolo da tragédia colonial e também da instituição casamento. Evidencia-se, por meio da narrativa, a visão decadente dessa instituição tida por sagrada, mas que revela, afinal, se valer apenas de "aparências". Os casamentos de Evita/Alex e Helena/Forza não passam de farsas. Fica comprovado, então, para Evita/Eva, que o contexto da guerra (juntamente com outras descobertas que vêm

${ }^{424}$ JORGE, Lídia. A costa dos murmúrios. Lisboa: Dom Quixote, 1988, p. 155. 
atreladas a ele) causa desapontamentos, ainda que marque profundamente sua vivência particular e também a de outras mulheres.

Lídia Jorge, conhecedora da realidade do império decadente e da Guerra Colonial por experiência, apresenta, nesta obra, os últimos tempos do domínio português em Moçambique sob um olhar feminino que acaba por mostrar o discurso do Outro. Esse discurso é notadamente divergente em relação ao oficial. No romance, torna-se preponderante a mutação de valores, alguns dos quais, concretamente, a maioria dos frequentadores do terraço do Stella Maris, não conseguem perceber nem acompanhar. Os antigos valores guerreiros são reduzidos e, além deles, a cicatriz do capitão Forza Leal, símbolo do heroísmo guerreiro tradicional, perde valor:

A cicatriz foi uma bela marca enquanto se lutou com uma arma de lâmina, de que as balas acabaram por ser o sucedâneo projectil, e esteve por isso na base de grandes duelos, profundas admirações, redundantes amores. Depois a meio do século, caiu. ${ }^{425}$

A redução desses valores heroicos pode ter proporcionado às mulheres a possível libertação de vozes até então silenciadas. Com isso, elas propõem-se não somente se libertar como também rasurar o tradicional discurso masculino sobre a Guerra Colonial. Contudo, nessa aparente submissão (no romance da autora portuguesa, tomam-se como exemplo Evita e Helena), as mulheres escondem seus anseios de liberdade, de emancipação, de luta contra os valores de uma sociedade patriarcal que as mantinha sob o poder dos maridos.

No romance em questão, o tema da Guerra Colonial torna-se o motivo para o aprofundamento de temas paralelos: a tessitura da escrita; a memória; o feminino e a relação com o outro - o parceiro da relação amorosa; o tempo opressivo e de privação, marcado pela náusea e pelo tédio; o desejo de fuga para um outro espaço, talvez, onde as mulheres, sobretudo, pudessem experimentar a liberdade.

Vale dizer que a presença desses temas no espaço textual não significa, no entanto, sinal de alienação, pois, em nenhum momento, abandona-se a crítica à guerra, à sociedade e à política que a mantinham. Ao contrário disso, são denunciados atos de barbárie cometidos pelos colonizadores, tais como o "envenenamento dos africanos com álcool metílico". As personagens femininas (no caso, Eva/Evita), dotadas de uma singular "inteligência emotiva", compactuam com essas investigações, apesar de fazerem parte da minoria marginalizada.

\footnotetext{
${ }^{425}$ JORGE, Lídia. A costa dos murmúrios. Lisboa: Dom Quixote, 1988, p. 63.
} 
Para isso, a protagonista de $A$ costa dos murmúrios consegue suas investigações essencialmente através do jornalista Álvaro Sabino (o jornalista mestiço angolano, que permite à personagem articular a denúncia histórica e descobrir o prazer do próprio corpo), com quem inicia, como afirmou Paula Jordão em seu artigo intitulado "A costa dos murmúrios: uma ambiguidade inesperada", "uma relação ambígua". Jordão (1999) afirma isso porque:

Embora aparentemente de resistência política ao regime colonial, a relação de Evita e Sabino acaba por evidenciar o conformismo e até o comprometimento de ambos com esse mesmo regime. Para Sabino, o seu acto de resistência limita-se à semanal coluna panfletária (inofensiva e "indecifrável", segundo o "jornalista gordo") [...] Para Evita, o seu acto de resistência limita-se apenas da aquisição de um maior conhecimento acerca dos assassínios, não o usando, no entanto, para os denunciar na prática. ${ }^{426}$

Essas descobertas de Eva/Evita na tentativa de desmistificar acontecimentos considerados durante muito tempo como tabus do discurso histórico e ideológico da cultura portuguesa se mostram, no entanto, como um convite à reflexão, impensável num tempo de censura salazarista. Ocorre, de fato, um nascimento não somente da consciência de si, mas de um conhecimento histórico da personagem, uma espécie de nascimento para o mundo. Nessa fase, a protagonista atinge a maturidade quando passa significativamente de Evita para Eva, indicando um novo e adulto estágio de consciência. Por meio desse despertar, a personagem parece estar apta a situar-se numa linha de temporalidade que contém o passado, o presente e um possível projeto de futuro.

Acredita-se que é, prioritariamente, por meio da escrita que Eva deixa transparecer o seu "eu" feminino. Lídia Jorge, primeiramente, coloca sua protagonista na posição de leitora, mas não se trata de uma leitora comum, passiva. Eva não somente lê, mas também desenvolve uma reflexão sobre os fatos, dando vez a um fluxo de raciocínio. Dessa forma, a autora aponta para a participação do leitor como um construtor da narrativa. Nesse sentido, emerge da protagonista uma voz que antes estava silenciada, possibilitando a recriação de uma nova história e, por consequência, da sua própria história. Certo encorajamento toma conta da noiva de Luís Alex, pois, como

\footnotetext{
${ }^{426}$ JORDÃO, Paula. "A Costa dos Murmúrios: Uma Ambiguidade Inesperada”. In: Lídia Jorge: in other words - por outras palavras. Portuguese Literary \& Cultural Studies Subscription. Center for Portuguese Studies and Culture. University of Massachusetts, Dartmouth, 1999, p. 56.
} 
disse Santos (2003), "dizer é não ter medo de expor o ser que existe por detrás de um texto"$^{427}$.

Na narrativa de Lídia Jorge, de acordo com Medeiros (1999), Eva certamente "desconstrói a narrativa tradicional de guerra, e é por isso que se pode dizer que, simultaneamente, teoriza e reescreve o que o ato de escrever sobre a guerra possa significar." ${ }^{428}$ Ao praticar a (re) escrita, Eva, por meio de uma leitura reflexiva, interpreta o que está lendo, pois todo o ler subentende uma ação e, como a protagonista diz, "Não se lê, decifra-se". ${ }^{429}$ Durante esse processo, ela confronta a realidade proposta no conto com a sua atual conjuntura. E é nesse jogo de realidades que eclode a singularidade de cada pessoa, ou seja, da mesma pessoa em conjunturas e sob pontos de vista diferentes.

Eva exerce a função de escritora, escritora de si mesma e de sua própria história, no sentido pessoal e histórico. Apresenta-se, em A costa dos murmúrios, paralelamente, o papel do escritor que se refere a Lídia Jorge e Eva Lopo. O papel exercido pela autora parece similar ao do historiador, o historiador tradicional, que relata os fatos do ponto de vista oficial. Ao passo que a personagem, em sua fase de maturidade, além de apresentar não apenas uma só visão, parece preocupar-se em refletir a respeito do homem, sua época e as condições históricas que lhe possibilitaram ser o que é, num trabalho de metaficção historiográfica.

Essa reflexão sobre o homem como indivíduo está mais voltada, em se tratando dessa narrativa, à mulher. Afinal, Lídia Jorge coloca a mulher como a condutora da narrativa. Porém, não quer dizer, como se nota ao longo da narrativa, que Eva seja resguardada dos acontecimentos. Ao contrário, nesse ponto, tem o mesmo tratamento dos homens. A esse respeito, Lídia Jorge discute em uma entrevista:

\footnotetext{
Enquanto autor da narrativa, enquanto posto de observação, eu não dispo as minhas saias, nem meu cabelo para tornar uma perspectiva andrógina. Seria um erro se eu quisesse me colocar nessa perspectiva. Acredito que a literatura produzida não tem sexo. Mas a fonte que a produz tem. ${ }^{430}$
}

\footnotetext{
427 SANTOS, Carina Faustino. A Escrita feminina e a guerra colonial. Lisboa: Vega, 2003, p. 92.

${ }^{428}$ MEDEIROS, Paulo de. Memória Infinita. In: Lídia Jorge: in other words - por outras palavras. Portuguese Literary \& Cultural Studies Subscription. Center for Portuguese Studies and Culture. University of Massachusetts, Dartmouth, 1999, p. 65.

${ }^{429}$ JORGE, Lídia. A costa dos murmúrios. Lisboa: Dom Quixote, 1988, p. 147.

${ }^{430}$ Entrevista com Lídia Jorge. Folha de São Paulo, 05/04/1998.
} 
Isso mostra, sem dúvida, que há, no conjunto de sua obra, pelo menos nas que pertencem ao corpus deste trabalho, a perspectiva da visão feminina e esta se sobressai. Essa perspectiva, no caso da protagonista Evita / Eva, não se resume a um ponto de vista. Há indícios de que a personagem possa apresentar transgressão, sobretudo por ter vivenciado o contexto de repressão e de Guerra Colonial e, como já mencionado, pela sua perspicácia no que se refere a uma percepção bem desenvolvida, se comparada à das outras personagens do romance. Evidentemente, Helena, a de Troia, contribuiu para o desenvolvimento da consciência de Evita. Porém, Helena continua a esposa do capitão Forza Leal, permanece casada com o marido, ao passo que Eva parece almejar uma reconfiguração identitária. Eva desenvolve, mesmo que involuntariamente, uma consciência de si que sugere a construção de sua identidade.

Eva descortina, por meio de seu senso investigativo, o Império português, valendo-se da representação escrita, que registra o simulacro dos acontecimentos ocorridos em Moçambique durante o período da Guerra Colonial. Ela emite a voz feminina, dá vazão ao seu corpo e à sua memória, ao acaso e ao enigma. A voz, até então submersa no silêncio do "eu" feminino, escreve o que se toca, se ouve, se vê e se respira, e está agora marcada pela ruptura e pela alteridade. Essa mesma voz, agora audível, caminha para o resgate do seu "eu" interior, rumo à construção da sua identidade pessoal.

Para tanto, Lídia Jorge defende que é necessário resgatar as vozes que estão à beira de extinguir-se; de fato, a voz feminina sobressai. Atenta-se, portanto, para o fato de que é preciso falar, quebrar o silêncio para que o acontecido não deixe de existir. Porém, embora Eva desenvolva bem a função de propagadora da voz silenciada, em contrapartida, no momento em que os colonizadores retornam do combate ao hotel (suposto lar em Moçambique) ."do rumor intenso do regresso, o Stella Maris mergulhou no silêncio" 431

Acredita-se que esse silêncio venha daqueles que pressentem ou têm consciência (como é o caso de Luís Alex) de que o término da guerra aponta para a decadência do Império Português. O alferes se mostra indignado ao ouvir a leitura de Evita sobre as notícias no jornal:

"Pára, repete lá - quem é que empala? África empala a Europa, é ou não é? " "É" [...] "esse pasquim está cheio de gente blackpower. Aposto que é um cabrão dum branco querendo o poder de preto! Mas

${ }^{431}$ JORGE, Lídia. A costa dos murmúrios. Lisboa: Dom Quixote, 1988, p. 243. 
espera - o gajo diz aí, ora lê de novo, que desde sempre a Europa possuiu a África? [...] Mentirosos, impostores do futuro!" [...] "Felizmente que ninguém lê nada disso, ninguém perde tempo com loucuras dessas. A realidade é sempre mais forte" ${ }^{432}$

Neste caso, o melhor seria que o silêncio perdurasse, pois era muito mais articulado do que a voz. Seria mais viável que ficasse só um murmúrio provindo da voragem invisível que falava, mas tudo para se ouvir imensamente pouco. Afinal, aquela era a sociedade do disfarce, em que nada daquilo exprime realmente alguma importância; portanto, não deve ser dito às claras ou em voz alta. Deve ser expresso por meio de sussurros, murmúrios.

De qualquer forma, a despeito dessa tentativa de camuflagem por parte do colonizador, a legitimidade da guerra é posta em questão por Lídia Jorge. Mesmo que restem somente os murmúrios, essa escrita foi recriada de alguma forma e desenvolvida a partir de um ponto de vista feminino. Pelo que mostra o texto, trata-se de uma escrita articulada de maneira fragmentada e talvez inconsistente, pelos atributos que se desprezam nas mulheres e igualmente nos não europeus, "passivos, imaturos, não sofisticados, sem espírito de iniciativa ou de poder intelectual, necessitando se ser guiados ou governados" 433 .

Algumas dessas características não se enquadram na protagonista do romance da autora portuguesa, embora se tenha consciência de que esse contexto repressor interfere na construção da identidade pessoal e, com mais evidência, na identidade feminina. No caso, Eva possui certo grau de instrução e desenvolve a escrita de forma autorreflexiva uma reflexão marcada por um tempo interior e feminino, capaz de guiá-la no sentido de um encontro consigo mesma, uma descoberta de seu "eu", uma busca da própria identidade.

É exatamente essa imagem feminina que Lídia Jorge pretende enfatizar, da mulher forte, destemida, capaz de transgredir pautada nas experiências vividas e na memória. Isso se processa graças à palavra escrita, que possibilita a libertação do sujeito. Uma liberdade interior que, gradativamente, integra as mulheres e singulariza as vozes femininas.

\footnotetext{
432 JORGE, Lídia. A costa dos murmúrios. Lisboa: Dom Quixote, 1988, p. 248-249.

${ }^{433}$ JORDÃO, Paula. "A Costa dos Murmúrios: Uma Ambiguidade Inesperada" . In: Lídia Jorge: in other words - por outras palavras. Portuguese Literary \& Cultural Studies Subscription. Center for Portuguese Studies and Culture. University of Massachusetts, Dartmouth, 1999, p. 54.
} 


\section{CONSIDERAÇÕES FINAIS}


Utilizando como objeto de pesquisa os quatro primeiros romances da autora portuguesa Lígia Jorge ( $O$ dia dos prodígios, $O$ cais das merendas, Notícia da cidade silvestre e A costa dos murmúrios, seguindo a ordem de publicação), este trabalho propôs-se estudar como se processou o percurso identitário das protagonistas das obras referidas.

Ao longo deste estudo, procurou-se mostrar que cada protagonista, à sua maneira é regida pelo contexto em que esteve inserida, direta ou indiretamente, buscava o conhecimento de seu "eu", ou seja, a consciência de si, rumo à construção da identidade não somente coletiva, mas especificamente feminina.

Essa consciência de si parecia ser recobrada por meio de atividades desenvolvidas artesanalmente pelas mulheres que protagonizaram a ação. Por outras palavras, bordar, limpar, costurar, escrever, discorrer a respeito do que se vivia ou queria viver, organizar em carta e narrativa, tentar formar uma estrutura de relevância e sentido, desenhar por si uma identidade e um projeto, era a maneira encontrada para testar a própria autonomia desses sujeitos mulheres no mundo, como seres atuantes e capazes de interpretar.

Em $O$ dia dos prodígios, o bordar e o limpar eram os afazeres que preenchiam parte do tempo da personagem Branca Volante e também os dias de Carminha Parda, respectivamente. Branca, antes de iniciar o bordado por imposição do marido, cuidava somente dos afazeres domésticos (tarefas do lar e também dos filhos e do marido), e todas as suas atenções estavam voltadas somente para essas obrigações, esquecendo-se completamente de si mesma.

Sujeitava-se, Branca, aos maus tratos do marido e era tratada sem consideração. Pássaro Volante, o marido, acreditava que se a esposa estivesse com todo o tempo ocupado, não poderia afastar seus pensamentos do lar. Por esse motivo, para mantê-la ocupada ao máximo, Pássaro lhe impôs o bordado. O velho camponês não imaginava que aquela atitude de fato despertaria em Branca uma aproximação, mas não com as obrigações do lar como ele previa, e sim consigo mesma.

Carminha Parda, outra personagem do primeiro romance de Lídia Jorge, era discriminada e estigmatizada por todos do vilarejo, por conta de sua filiação - era filha do pároco da cidade que saiu de lá fugido quando descobriu que a amante, Carminha, a Rosa, estava grávida. Em razão disso, Carminha, a filha, entrega-se à passividade e ao isolamento, permanecendo na clausura, ou seja, prisioneira dentro de sua própria casa e entregue à limpeza de uma janela, que era o meio mais constante de ver o mundo lá 
fora. Enquanto praticava o ofício de limpar a janela, como se quisesse limpar de si aquele destino que lhe fora imposto - ser filha de um pai incógnito -, Carminha desenvolvia, muito timidamente, uma espécie de contestação interior.

Logo no início da narrativa, Carminha Parda se mostrava condenada e conformada com o seu futuro - se é que tinha algum -, esperar por alguém, especificamente um noivo, que viesse de fora para se casar com ela, já que no vilarejo ninguém se arriscaria a isso, tendo conhecimento de sua filiação. Até um suposto "noivo" morreu em combate, e a opção que restou foi o Sargento Marinho (um excombatente sanguinário que adentrou o vilarejo para contar vantagens sobre a Guerra Colonial).

Carminha, ao presenciar o sargento maltratando cães em praça pública, decidiu que não ia se casar com aquele homem que julgava monstruoso. Após recusar o cruel sargento, a moça descobriu que o seu futuro era ali mesmo em Vilamaninhos, ao lado de Macário, um lunático cantor que lá vivia. Macário era apaixonado por Carminha desde sempre, mas ela acreditava que o seu destino estava fora dali. Além disso, o cantador não era o modelo de soldado garboso e corajoso com que Carminha sonhava; era apenas, para ela, um jovem que passava a maior parte do tempo dormindo ou, quando não, cantarolando poemas.

Havia, em Macário, algo de especial que talvez tivesse sido desenvolvido por possuir um dom musical. A união de Carminha Parda e Macário, mesmo naquele espaço alienado de Vilamaninhos, talvez pudesse ser útil para que desenvolvessem ali um começo, algo que indicasse algum avanço, mesmo que com o mínimo de significância, para que saíssem do estágio de estagnação.

Branca Volante, assim como Carminha, também permaneceu no vilarejo, mas por opção. Com a protagonista, verificava-se que a mudança era diferente. Branca trazia consigo um dom que estava adormecido e esquecido em razão das circunstâncias que vivia (de submissão, alienação e estagnação) desde que era menina e, ainda, devido às obrigações que lhe haviam sido infligidas.

O bordado fez ressurgir nela o dom de adivinhar, e isso, para Pássaro Volante, era motivo de medo. À medida que a protagonista bordava o dragão na colcha, desenvolvia em seu interior uma força que ela mesma desconhecia. Essa força ganhava proporções que faziam Branca enfrentar o marido, chegando até a dar-lhe uma surra, algo que nunca havia acontecido anteriormente e que Branca jamais sonhava que aconteceria. Além disso, chegou ao vilarejo um forasteiro que dizia gostar de Branca e a 
convidou para irem embora dali, prometendo a ela que montariam uma tenda para Branca ler o futuro dos outros. Branca se recusou por acreditar, assim como Carminha Parda, que era possível construir algo no vilarejo.

O término do bordado e os acontecimentos inesperados (a recuperação do dom de adivinhar; a surra no marido; a aparição do forasteiro; a decisão de permanecer em Vilamaninhos) eram indícios de que Branca parecia estar se descobrindo. As atenções agora estavam voltadas primeiramente para si mesma, e não mais para os outros.

Evidentemente, em relação a Carminha, Branca Volante encontrava-se num estágio de desenvolvimento superior de consciência. Porém, ao longo do estudo observou-se que foi um despertar de conhecimento interior muito precário, quase que germinal. Provavelmente, isso se dá devido ao contexto histórico/social em que as mulheres desse romance estão inseridas.

Viviam em meio ao contexto ditatorial português, especificamente no final da ditadura (na emergência da Revolução de 1974), mesmo assim, o comportamento não somente das mulheres, mas também de toda aquela comunidade rural, se mostra totalmente avesso às transformações ocorridas naqueles últimos anos de ditadura (época em que a sociedade portuguesa, principalmente das regiões mais centralizadas, já visualizava, com a aproximação da Revolução dos Cravos, um prenúncio de melhora no que se refere a opressão imposta pelo regime). Tratava-se de um comportamento completamente alheio ao acontecimento histórico tão significativo para o povo português. Mas identificou-se que, a despeito disso, havia na personagem Branca uma esperança de renascimento, de descoberta de si.

No segundo romance de Lídia Jorge, O cais das merendas, o cenário era rural, assim como em $O$ dia dos prodígios, mas nessa narrativa apresentavam-se dois espaços: o espaço rural (sítio Redonda) e o espaço mais desenvolvido (hotel Alguergue, na praia das Devícias). Havia um grupo de camponeses, habitantes da Redonda, interessados em obter melhores condições de vida em razão da construção do hotel e principalmente do trabalho que lá arranjavam. O trabalho no hotel significava para eles o progresso, o contato com o estrangeiro, já que muitas pessoas vindas de fora se hospedavam ali.

Esse contato, externo ao ambiente campestre a que estavam acostumados, contribuía para o esquecimento das raízes do povo da Redonda. De certa forma, estavam-se deixando corromper pelo luxo que o hotel representava, a ponto de perderem suas identidades. Até mesmo a língua do estrangeiro era incorporada pelos camponeses, e as merendas (breves lanches que tinham entre o intervalo de um trabalho 
e outro na roça) se transformavam em "parties", termo que, na visão deles, remetia à fartura, ao luxo.

No início, estavam satisfeitos com seus ofícios no hotel, exceto a menina Rosária, filha de Sebastião Guerreiro, o maître do hotel, que estava intrigada com a situação. Ao mesmo tempo que a moça, assim como os outros, se encantava com o esplendor do hotel, se preocupava também com suas origens.

A filha de Sebastião não se instalou definitivamente na hospedaria, como os demais. Ela ficou de um lado para outro, entre a Redonda (onde habitava sua mãe, Santanita Trigal, que não conseguia se habituar ao ambiente do hotel) e o Alguergue (lugar em que moravam seu pai Sebastião Guerreiro e todos os outros funcionários). Rosária era a única personagem que demonstrava inquietude. Em suas idas e vindas pela praia, a menina mostrava-se preocupada com a vontade que os outros tinham de se desvencilhar do passado da Redonda. Rosária sabia que o apagamento do passado não seria benéfico para os camponeses.

Ao contrário disso, seria uma forma de desprezar as raízes e vivenciar somente o novo. Estava nítido que não haveria possibilidade de progressão se não houvesse uma conservação e um resgate do passado. Não era possível praticar o apagamento total daquilo que era parte da história, e Rosária, mesmo que inconscientemente, apresentava sinais de que tinha conhecimento dessa realidade.

A preservação do passado é algo latente e enraizado na sociedade portuguesa. Manter a tradição histórica para a conservação da memória e também para relembrar tempos em que a nação portuguesa esteve no apogeu (época das grandes navegações, por exemplo) é uma maneira de pertencer a Europa e preservar o orgulho de ser português. Resgatar o passado e recorrer a ele, sempre que necessário no presente, é uma maneira de ascender e traçar uma perspectiva boa para o futuro. Essa é uma característica marcante do povo português. O passado os impulsiona para viver o presente e dar continuidade no futuro. Uma vez que há a tentativa de apagamento do passado, o presente não se concretiza e o futuro não se constitui.

Na narrativa de Lídia Jorge, a personagem Rosária insiste no resgate desse passado que pelo gosto da maioria ficaria esquecido na Redonda. Santanita, por exemplo é uma das personagens que também permanece no sítio (lugar que representava o passado estagnado). As outras personagens, deslumbradas pelo novo e pelo luxo que representava o Hotel Alguergue, queriam descartar definitivamente o passado doloroso da Redonda. Mas ao perceberem que não haviam se adequado ao luxo 
- em primeiro lugar, porque eram tratados meramente como empregados; em segundo, porque não haveria possibilidade de vivenciarem somente aquele contexto sem levar em consideração o passado na Redonda -, a lembrança do tempo no sítio começa a vir à tona. Sentem-se nostálgicos e com uma espécie de saudade do passado.

Isso ocorre devido ao Saudosismo (corrente estética ocorrida em Portugal no século XX, cujo mentor do movimento foi o poeta Teixeira de Pascoaes). Essa corrente ressaltava que o ser humano viveria sua vida com base na saudade do passado e que, além disso, os adeptos ao movimento seriam capazes de mudar sua atitude de vida.

O Saudosismo tem como base a saudade, que Pascoaes considerava o traço espiritual que definia a alma humana (portuguesa, em especial). Segundo o poeta, este sentimento é descrito pela Literatura Portuguesa ao longo do tempo. Por ele, a saudade é elevada de um simples sentimento humano, individual, a um plano místico, que determina a relação do Homem com Deus e com o mundo. O Saudosismo, portanto, corresponde a uma doutrina política e social.

Esse movimento tinha como pretensão a regeneração do país, pois surgia em meio a uma mentalidade nacionalista, tradicionalista e neo-romântica. Faria isso, portanto, utilizando a saudade como princípio renovador que agiria através da ação cultural (literatura e demais artes em que o saudosismo se manifestou).

Essa mentalidade saudosista está enraizada no povo português e, pelo que se nota na narrativa de Lídia Jorge, a atitude saudosista começa a emergir quando percebem que o luxo do hotel distanciado da pobreza da Redonda não proporcionaria ascensão. Seria necessário resgatar aquilo que definia a alma portuguesa, o passado (mesmo que este trouxesse lembranças desagradáveis), para estabelecer relação com o que estava externo a Redonda. Desse modo, seria possível constituir-se como sujeitos e, consequentemente, iniciar a construção de identidade.

Por essa razão, Rosária tentava, de alguma forma, manter o contato com a Redonda. A maneira que a filha encontrou para comunicar-se com a mãe foi escrevendo-lhe cartas. No período em que trabalhou no hotel, Rosária teve contato com o novo, já que o hotel Alguergue, revestido de muito luxo, representava exatamente o oposto em relação ao espaço da Redonda.

A mãe de Rosária e a Redonda representavam o passado nada promissor, mas simbolizavam a preservação das raízes e da cultura daqueles camponeses. Sebastião Guerreiro, o pai da menina, juntamente com todo o conhecimento que adquiriu com os estrangeiros e também por habitar o Alguergue, representava o luxo, a ascensão, a 
relação com o externo, a globalização. A filha de Santanita e Sebastião ficava dividida entre esses dois mundos. No início, quando escrevia cartas à mãe e esta lhe respondia, Rosária sentia-se bem por manter o vínculo com Santanita. Houve um determinado momento em que a menina não teve mais contato com os pais, e isso a fez sentir-se sem rumo.

Na realidade, aos olhos de Rosária, não havia mais lugar no mundo para si. Considerava que nenhum dos dois espaços eram convenientes para si porque não se sentia confortável em lugar algum. Esse sentimento de não pertencimento levou Rosária a uma crise de identidade e, consequentemente, ao suicídio.

O desenrolar da narrativa levou a crer que a presença da escrita (como uma manifestação interior e maneira de interpretar o mundo) possibilitou a Rosária um mergulho no seu eu e contribuiu para que a menina adquirisse uma visão diferenciada sobre os dois espaços. Ela não considerava a Redonda e a cultura que ali se mantinha como uma memória que deveria ser descartada, mas como as origens que deveriam ser mantidas. Ao passo que também não supervalorizava o espaço da praia das Devícias (especificamente o Alguergue), essencial pela ostentação que representava, mas pelos benefícios que aquele contexto globalizado poderia oferecer aos camponeses.

Esses dois universos desencadearam em Rosária um grande conflito interno, pois não era capaz de escolher entre um dos espaços, simplesmente porque não era possível. Ela desejava resgatar sua identidade perdida e, concomitantemente, queria aproveitar o progresso que a instalação do hotel oferecia.

Considerou-se que essa visão pouco mais ampliada de Rosária tenha sido desenvolvida pelo exercício da escrita: (que proporcionou um mergulho no seu interior, favorecendo um início do conhecimento de si) e também pelo desejo de manter as raízes com o passado (o que elevaria a saudade a um sentimento humano, individual, possibilitando melhor contato do sujeito com o mundo). Esta perspectiva ampliada da filha de Sebastião Guerreiro favoreceria a ela uma possível consciência de si rumo à construção da identidade, o que, para os aldeões, tornou-se mais difícil.

Já no primeiro romance, o início do despertar da consciência de si veio por meio do bordado. Além da ação de bordar (visível em $O$ dia dos prodígios), a ação de escrever (notada no segundo romance) também esteve presente no terceiro romance de Lídia Jorge: Notícia da cidade silvestre. O cenário, nessa obra, não se referia ao Portugal rural, como nos dois anteriores, a ação se passava em Lisboa no ano de 1976. O ambiente citadino era propício para que a mulher pudesse exercer a liberdade de 
trabalhar fora do ambiente doméstico (em razão dos movimentos feministas e de alguns direitos que a mulher havia conquistado) e era exatamente o que acontecia com Júlia Grei, a protagonista da trama.

A priori, Júlia, quando ainda era casada, se apresentava como uma jovem senhora, casada e cuidadora do lar, com um filho (o menino João Mário, apelidado de Joia) e o marido (David Grei). A morte do marido fez com que Júlia, sem opção e com ajuda de uma amiga (Anabela Cravo), arrumasse um emprego para poder cuidar do filho. A viuvez de Júlia foi uma oportunidade para a moça usufruir de sua liberdade, mas, sentindo-se desnorteada acabou apegando-se a Anabela, amiga datilógrafa que passa a desempenhar sobre Júlia papel semelhante ao que David exercera.

Anabela, que trabalhava em um escritório de advocacia, era uma moça solteira, determinada e tinha enorme influência sobre Júlia. Ela morava com os padrinhos e, quando criança, fora estuprada por aquele que a criou como se fosse seu pai. Anabela, aproveitou-se da situação, chantageou o padrinho e ofereceu a ele o silêncio em troca dele lhe custear os estudos. Por essa razão, a jovem datilógrafa estudou direito e se formou.

A relação entre as duas moças era de subalternidade, pois Júlia obedecia a tudo que Anabela ordenava. Júlia praticamente se anulou para satisfazer aos desejos de Ana e estabelecia com a amiga uma relação de dependência. A esposa de David era dotada de uma fragilidade que a tornava incapaz de tomar qualquer decisão sem o aval de Anabela. Além disso, sentia-se também muito só, razão pela qual queria sempre a amiga por perto.

As duas passam por muitos percalços: Anabela abortou propositalmente um filho que não sabia direito de quem era; Júlia também se submete a um aborto de um relacionamento que teve com Arthur Salema. A amizade das duas é rompida porque Anabela sentiu-se enganada por Júlia, já que a viúva de David não havia contado à amiga a respeito de seu relacionamento com Arthur. Júlia, sem a amizade de Ana, se vê obrigada a se prostituir para o seu próprio sustento e também de seu filho; enfim, a vida de Júlia se desestabilizou completamente.

Em meio a toda essa turbulência, Júlia não se importava muito com o filho $\mathrm{e}$ num descuido dela, o menino toma veneno de rato e fica muito doente. Desde então, Júlia começa a escrever tudo que ocorre com o filho, em um caderno amarelo, uma espécie de diário. A jovem senhora começou a cuidar de seu filho e, à medida que isso ocorria, ia registrando os fatos no diário. Nesse período, Júlia não se valia mais da 
prostituição e, em razão disso, a precariedade da situação financeira da amiga de Anabela se agravou. Para sustentar a si e ao filho, além do trabalho na livraria do Sr. Assumpção, Júlia desenvolvia um trabalho extra: costurava bonecas.

Era um trabalho manual, pouco rentável, mas era o que havia conseguido. Anabela, mesmo afastada da amiga, comprava, sem que Júlia tomasse conhecimento, as bonecas que a mãe de Joia confeccionava, era a maneira que a estudante de direito tinha encontrado para ajudar a amiga. A construção das bonecas fazia Júlia pensar a respeito da situação em que se encontrava, sobre seu filho, sua vida. Começou-se uma espécie de reflexão, o que nunca havia acontecido antes.

O escrever no diário significou, para Júlia, em primeira instância, expor o problema que o filho Joia estava enfrentando. Ao longo dos registros, ela percebeu que o menino estava correndo risco de morte e que precisava da atenção da mãe. Começava a despertar em Júlia uma preocupação, instinto materno, que até aquele momento a protagonista desconhecia. Uma mudança de comportamento surgiu, não somente a respeito do filho, mas também em relação a Anabela Cravo. Com o garoto já fora de perigo, a funcionária da livraria não cessa seus relatos no diário e a percepção de si começa a aflorar.

Júlia percebeu que poderia seguir sua trajetória de vida sem que Anabela estivesse por perto. Essa descoberta veio à tona com a proximidade do filho, a amizade de Fernando Rita (escultor) e a presença de um cachorro que Joia havia ganhado de Fernando enquanto esteve no hospital. Júlia estava constituindo uma família, laços de amor entre mãe e filho e, com Fernando Rita, laços de amizade. Encontraram-se novamente as duas amigas, mas Anabela não tinha mais o domínio sobre Júlia. A amiga de Fernando Rita percebeu que era possível recomeçar.

A escrita novamente se fez importante na trajetória de autoconhecimento da protagonista. Júlia descobriu que era possível construir, ao lado do filho e do então companheiro Fernando, relações de afeto. Para que Júlia tivesse essa percepção, era necessário que Anabela, sua sombra em negativo, se afastasse. Quando as duas se aproximaram pela última vez, Júlia estava portando uma arma, uma faca, apenas para se precaver. O que era antes fragilidade e dependência em Júlia, transformou-se em força e coragem. Em outros tempos a protagonista nunca teria tido essa iniciativa.

Observou-se que estas reações foram iniciadas pelo costurar (quando Júlia inicia o processo de confeccionar bonecas), e, principalmente, pelo escrever. Este segundo ato ativou na protagonista um sentimento de mãe, que a fez recobrar uma consciência de si. 
Além disso, Júlia percebeu que sempre haveria tempo para reconstruir uma nova vida com perspectivas positivas e com autoconfiança.

Neste contexto de Notícia da cidade silvestre, diferentemente dos dois romances anteriores, a protagonista se mostrou com um grau de consciência mais desenvolvido. Isso se deu devido ao cenário dessa terceira narrativa (época em que as mulheres já haviam conquistado alguns direitos) que contribuiu para que Júlia percebesse que não estava descartada a possibilidade de recomeçar. Esta "liberdade", que era atribuída às mulheres daquela época, não anula as dificuldades que, evidentemente, a protagonista iria enfrentar dali por diante.

Decerto, em $O$ dia dos prodígios e $O$ cais das merendas, o contexto da narrativa dificultou muito o desenvolvimento da consciência daquelas mulheres. No terceiro romance, o período apresentado no texto (1976 - época em que as mulheres já haviam vencido alguns obstáculos, no que se refere a liberdade para realizar algumas ações) favorecia Julia, mas a amiga de Anabela Cravo ainda tinha um longo percurso em busca de sua identidade.

Em A costa dos murmúrios, último romance que compôs o corpus deste estudo, a escrita também esteve presente, porém de maneira mais intensa. A divisão da narrativa em duas partes (conto / romance) sugeriu dois momentos e de fato houve. No conto, a história se passou em 1968, em Moçambique, no contexto da Guerra Colonial; no romance, em 1988, em Lisboa, Portugal.

No conto, embora estivessem em meio à Guerra Colonial, a harmonia reinava. Era a festa de casamento do alferes Luís Alex e Evita em um hotel (o Stella Maris), lugar bonito e agradável, construído especificamente para o horário de descanso dos combatentes lusitanos e suas respectivas esposas. As mulheres ficavam na hospedaria, na maioria das vezes sozinhas, à espera do retorno de seus maridos. Na primeira parte da narrativa, as ações se desenvolviam na mais perfeita ordem. Todos demonstravam muita satisfação, os noivos muito apaixonados e aquela celebração simbolizava para todos um momento de felicidade.

No romance, a segunda parte do texto, Evita (a moça aparentemente ingênua e apaixonada) se apresenta como Eva Lopo, vinte anos mais velha. Ali, a mulher em sua fase madura, relatou o conto "Os gafanhotos" sob outra perspectiva. Aquele cenário que antes era de glamour e felicidade se transformou.

O hotel Stella Maris tinha sido construído para proporcionar aos seus hóspedes / moradores certo conforto, mas a realidade no entorno daquela edificação era 
catastrófica. Havia negros moçambicanos sendo mortos injustamente, colonizadores portugueses querendo tomar posse de um território que não lhes pertencia e, para conseguirem o que ambicionavam, não hesitavam em destruir o que viesse a frente.

Apenas vinte anos depois, Eva / Evita teve condições de narrar o que realmente acontecera. Isso foi possível porque a protagonista, desde a juventude, já apresentava um senso investigativo, havia frequentado a universidade e era estudante de história. Em sua fase adulta, Eva se torna escritora e reescreve, sob uma perspectiva feminina, o ocorrido em 1968.

Evita descobriu, com o auxílio de Helena de Troia (mulher do capitão Forza Leal, uma espécie de mentor negativo do alferes Luís Alex) que seu noivo não era apenas um alferes ex-estudante de matemática, mas também um homem cruel, que, enquanto estava em combate, matava os negros friamente e com prazer. Houve, naquela época, um massacre. Muitos corpos de negros moçambicanos apareceram jogados ao mar, depois de terem ingerido um líquido contido em garrafas. Evita investiga e suspeita que, na verdade, os negros tinham sido envenenados. Ela foi até o jornal, procurou o jornalista Álvaro Sabino (com quem teve um caso) e acabou confirmando o envenenamento. A notícia não foi adiante porque a imprensa camuflava as notícias, estava mancomunada com os colonizadores, e Evita não podia levar aquilo adiante sozinha - com certeza não lhe teriam dado crédito.

Eva, então, relatou todas essas situações. O contexto de 1988 era mais propício (no que se refere à liberdade de expressão pouco mais acessível) para que a mulher pudesse escrever, expor seus ideais. A escrita encorajou a protagonista a externar seu ponto de vista. À medida que seu texto se desenvolvia, Eva tomava conhecimento de si e, consequentemente, da realidade que a cercava.

Essas descobertas foram possíveis porque Eva/Evita, diferentemente das outras mulheres presentes no romance, tinha conhecimento histórico. Ao adentrar o ambiente moçambicano (cenário de seu casamento e também da Guerra Colonial), ainda na sua mocidade, quando acompanhava o noivo que estaria em combate, Evita já tinha frequentado, mesmo que por um curto período de tempo, uma universidade. Isso proporcionou a Eva um conhecimento que as outras não tinham. Além disso, Eva tinha conhecimento do que estava ocorrendo, de fato, no contexto em que estava inserida, enquanto as outras deixavam-se influenciar pelos atrativos luxuosos que o hotel Stella Maris lhes proporcionavam, não percebendo o que de fato estava acontecendo ao redor. Para as outras mulheres, inclusive para Helena de Troia, elas estavam apenas 
acompanhando seus maridos numa expedição comum de trabalho e ficavam a espera deles, num ambiente confortável, enquanto eles não retornavam do trabalho. Evita sabia que algo de errado estava acontecendo fora do hotel e essa desconfiança a fez perceber que aquele era um contexto de guerra e, ainda, que o seu noivo e os outros oficiais estavam exterminando pessoas inocentes.

Eva, com sua ânsia de investigação, mostra que adquiriu conhecimento sobre a história e, por essa razão, deixava aflorar também uma consciência de si. A protagonista apresenta uma dimensão sobre os acontecimentos históricos que a cerca: A Guerra Colonial; o massacre aos negros; o real papel do colonizador (os oficiais portugueses) e do colonizado (os moçambicanos). Ao passo que as outras mulheres não possuem essa consciência.

Esse conhecimento histórico propicia ao indivíduo um dimensionamento social e humano. Evidentemente, esses dois elementos estão interligados e estabelecem relação com o tempo. Em outras palavras, quando não se tem conhecimento do passado, do que se passou há pouco tempo ou num período longínquo, a percepção do presente se torna difícil porque o passado determina o presente. Desse modo, preservar a memória, vivenciar o passado no presente, possibilita conhecimento histórico e, consequentemente, autoconhecimento.

Em se tratando de Eva, a consciência de si se deu pelo conhecimento histórico e também pela escrita. A noiva de Luís Alex não somente transpôs para o papel suas opiniões como também permitiu que outras pessoas tomassem conhecimento do que estava pensando. Porém, era um ponto de vista feminino, considerado extraoficial, exatamente pela pouca importância que se dava a algo relacionado à mulher, mesmo Eva sendo escritora.

Por conta disso, aquele relato não passou, como constou no romance, de um "murmúrio", algo que foi produzido em voz breve e baixa, com o propósito de não ser ouvido. Uma espécie de rumor contínuo, como o barulho incessante das ondas do mar. Sendo assim, "Os gafanhotos", sob ótica de Eva, representava algo que deveria ser repreendido, mais ou menos impublicável.

Verificou-se, por meio do estudo dos quatro primeiros romances da autora portuguesa, que a construção da identidade feminina se deu de forma gradativa e ascendente e sempre com o auxílio de ações desenvolvidas artesanalmente. Em $O$ dia dos prodígios, Branca Volante tinha como aparato o bordado, que a fez recuperar um dom adormecido e enxergar ao menos que existia. 
Rosária, de $O$ cais das merendas, por meio das cartas que escrevia à mãe, percebeu que havia a necessidade da conservação da cultura, das raízes. Observou-se, além disso, que as intervenções externas, como a globalização, atreladas à permanência das raízes, eram fundamentais para a constituição da identidade. Neste caso, Rosária acabou por representar a identidade perdida, mas apresentando sinais de que havia uma consciência da necessidade da junção entre esses dois mundos.

Em Notícia da cidade silvestre, Júlia buscou a consciência de si por meio da escrita e da costura. Conseguiu se desvencilhar da presença manipuladora de Anabela Cravo; desenvolveu um sentimento materno e conseguiu aguçar a esperança de que existia uma possibilidade de recomeço. A conscientização de si esteve mais em evidência neste terceiro romance do que nos dois anteriores. Para Júlia, aquilo era só um começo, mas, pelo que mostrou a narrativa, a protagonista jamais tinha demonstrado qualquer sentimento de esperança.

No quarto romance, A costa dos murmúrios, Evita / Eva Lopo, dentre as protagonistas, era a que mais progredia no que se refere ao desenvolvimento da consciência de si. Ela não somente se valeu da escrita para que isso acontecesse como também se tornou escritora. A escrita era seu ofício e isso despertou na protagonista um sentimento de investigação e busca da verdade, fatos que compuseram a busca de um conhecimento interior.

Constatou-se que, embora tenha havido essa gradação a respeito da conscientização das personagens, ainda com a transgressão de Eva Lopo, uma identidade feminina pronta, acabada, não se faz possível. A identidade se constitui em ciclos e sempre numa relação com o outro. Quando um ciclo se completa, automaticamente outro se inicia. Sendo assim, sempre haverá um caminho a ser percorrido, e a construção da identidade feminina não se findará enquanto houver transformação.

Especificamente no contexto português, devido a ditadura que durou quarenta e seis anos (regime este que evidenciava a obediência da mulher perante ao homem e também propiciava a estagnação e opressão da figura feminina), ascender, no que se refere ao reconhecimento da consciência de si, seria no mínimo custoso. A construção da identidade feminina nesse momento tornava-se inviável por algumas razões: relação de subalternidade evidenciada entre a figura masculina e feminina; obediência que a mulher devia ao homem. 
A relação de subalternidade existente entre homens e mulheres e, consequentemente, a supervaloração do masculino em relação ao feminino, dificultam o desenvolvimento da construção da identidade feminina. Certamente, como advertiu Clark e Holquist (1991), acerca da teoria de Bakhtin (que afirma a constituição da identidade somente na relação com o outro), essa relação não estava prevista de forma desarmoniosa, a ponto dos homens se valerem de atitudes violentas contra as mulheres para imporem autoridade.

No contexto patriarcal português os homens tinham necessidade de evidenciar o poder que exerciam sobre a família (mulher e filhos); a mulher tinha o dever de cuidar do marido, da casa e dos filhos. O que não se enquadrasse nesse âmbito doméstico se considerava inapropriado para o desenvolvimento identitário feminino. Desse modo, previa-se uma identidade feminina construída dentro dos preceitos de Salazar. E isso, sabe-se, prejudicava o desenvolvimento da consciência de si.

Nos textos de Lídia Jorge, a opressão se evidencia nos quatro romances (acredita-se que no último com menos intensidade, devido a consciência histórica que a personagem possui), e causa, na maioria das personagens femininas, estagnação. Esses fatores contribuem consideravelmente para o não desenvolvimento da consciência de si. Mas, ainda assim, a tentativa de reconhecer-se, de forma lenta, gradual e, pelo que as narrativas nos mostram, involuntária, prevalece, mesmo inconscientemente, e dá vazão a uma perspectiva que remete a esperança. 


\section{OBRAS DE LÍDIA JORGE}

O Dia dos Prodígio. Lisboa: Publicações Europa-América, 1980.

O Cais das Merendas. Lisboa: Publicações Europa-América, 1982.

Notícia da Cidade Silvestre. Lisboa: Publicações Europa-América, 1984.

A Costa dos Murmúrios. Lisboa: Publicações Dom Quixote, 1988.

A Última Dona . Lisboa: Publicações Dom Quixote, 1992.

A Instrumentalina. Lisboa: Publicações Dom Quixote, 1992.

O Conto do Nadador. Lisboa: Publicações Dom Quixote, 1992.

O Jardim Sem Limites. Lisboa: Publicações Dom Quixote, 1995.

A Maçon. Lisboa: Sociedade Portuguesa de Autores / Publicações Dom Quixote, 1997.

Marido e outros Contos. Lisboa: Publicações Dom Quixote, 1997.

O Vale da Paixão. Lisboa: Publicações Dom Quixote, 1998 (Título original e empregado em publicações estrangeiras - A manta do soldado).

O Vento Assobiando nas Gruas. Lisboa: Publicações Dom Quixote, 2002.

O Belo Adormecido. Lisboa: Publicações Dom Quixote, 2004.

Combateremos a Sombra. Lisboa: Publicações Dom Quixote, 2007.

O Grande Voo do Pardal. Lisboa: Publicações Dom Quixote, 2007.

Praça de Londres. Lisboa: Publicações Dom Quixote, 2008.

Contrato Sentimental. Lisboa: Sextante Editora, 2009.

Romance do Grande Gatão. Lisboa: Publicações Dom Quixote, 2010.

A Noite das Mulheres Cantoras. Lisboa: Publicações Dom Quixote, 2011.

Os Memoráveis. Lisboa: Publicações Dom Quixote, 2014.

O organista. Lisboa: Publicações Dom Quixote, 2014. 


\section{CORPUS}

JORGE, Lídia. O dia dos prodígios. Rio de Janeiro: Nórdica, 1984.

O cais das merendas. 4. ed. Lisboa: Europa-América, 1989.

Notícia da cidade silvestre. 2. ed. Lisboa: Europa-América, 1984.

. A costa dos murmúrios. Lisboa: Dom Quixote, 1988. 


\section{BIBLIOGRAFIA}

ALMEIDA, Ana Margarida Nunes de. Entre o dizer e o fazer: a construção da identidade feminina. Análise Social, vol. XXII (92-93), 1986, $3^{\circ}$ e 4º pp. 493-520.

ALONSO, Cláudia Pazos. Sex and Success in "Notícia da cidade silvestre": A tale of two cities. In: Lídia Jorge: in other words - por outras palavras. Portuguese Literary \& Cultural Studies Subscription. Center for Portuguese Studies and Culture. University of Massachusetts, Dartmouth, 1999.

ALVES, Bianca M.; PITANGUI, J. O que é feminismo. 2. ed. São Paulo: Brasiliense, 1982.

AMÂNCIO, Lígia. Gênero - Representações e Identidades. Revista Sociologia Problemas e Práticas. No 14, 1993, pp. 127-140.

AMARAL, Ana Luísa; Macedo, Ana Gabriela (org.) Dicionário da crítica feminista. Lisboa: Afrontamento, 2005.

ANDERSON, Perry. As origens da pós-modernidade. Trad. Marcus Penchel. Rio de Janeiro: Zahar, s.d.

BAKHTIN, Mikhail. A teoria do romance. In: CLARK, Katerina; HOLQUIST, Michael. Mikhail Bakhtin. Trad. J. Guinsburg. São Paulo: Perspectiva, 1998.

Estética da criação verbal. Trad. Maria Ermantina Galvão Gomes Pereira. São Paulo: Martins Fontes, 1992. (Col. Ensino Superior).

Questões de literatura e de estética: a teoria do romance. Trad.

Autora F. Bernardini \& alii. São Paulo: Hucitec, 1988.

BARRENO, Maria Isabel. O falso neutro. Lisboa: Instituto de Estudos para o Desenvolvimento, 1985.

BARROS, Diana Luz Pessoa de; FIORIN, João Luiz. (orgs.). Dialogismo, Polifonia, Intertextualidade. São Paulo: Edusp, 1994.

BARTHES, Roland. Crítica e verdade. Trad. Gerson de Souza. São Paulo: Perspectiva, 1970.

O prazer do texto. São Paulo: Perspectiva, 1977.

BEDASEE, Raimunda. Identidade e alteridade na Literatura Feminina. In: IV Congresso da ABRALIC - Literatura e diferença. 31 de julho a 03 de agosto, 1994, pp. 863-867.

BENJAMIN, W. A modernidade e os modernos. Rio de Janeiro: Tempo Brasileiro, $\mathrm{n}$. 41, 1975. 
BERG, Eliana. O dia dos prodígios: escrita prodigiosa. Revista Colóquio Letras. Ensaio, no 132/133, Abril, 1994, pp. 147-156.

BERMAN, Marshall. Tudo que é sólido desmancha no ar: a aventura da modernidade. Trad. Carlos Felipe Moisés, Ana Maria Ioriatti. São Paulo: Companhia das Letras, 1986.

BHABHA, Homi. A questão do outro. Diferença, discriminação e discurso do colonialismo. In: HOLANDA, Heloisa Buarque de (org.) Pós-modernismo e política. Rio de Janeiro: Rocco, 1991.

. O local da cultura. Belo Horizonte: UFMG, 1998.

BÍBLIA. Português. Bíblia Sagrada. Trad. dos originais: Centro Bíblico Católico. 111. ed. São Paulo: Editora Ave-Maria, 1997.

BIDERMANN, Hans. Dicionário ilustrado de símbolos. São Paulo: Melhoramentos, 1993.

BOSI, Alfredo. Ironia em perspectiva polifônica. Campinas, SP: UNICAMP, 1996.

BRAIT, Beth (org.) Bakhtin, dialogismo e construção do sentido. Campinas, SP: CAMPINAS, 1997.

BRIDI, Marlise Vaz. Cultura e Literatura: Portugal e Brasil. In: PEREIRA, Helena Bonito Couto; ATIK, Maria Luiza Guarnieri (orgs.) Língua, literatura e cultura em diálogo. São Paulo: Mackenzie, 2003, pp. 251-257.

- Modernidade e pós-modernidade na ficção portuguesa contemporânea. In: UNIVERSIDADE PRSBITERIANA MACKENZIE. Todas as Letras: revista de língua e literatura. São Paulo: Mackenzie, ano 7, n. 7, p. 75-81, 2005.

BULGER, Laura Fernanda «O Cais das Merendas» de Lídia Jorge: uma identidade cultural perdida? In: Revista Colóquio/Letras. Ensaio, n. ${ }^{\circ}$ 82, Nov. 1984, pp. 51-57.

BUTLER, Judith P. Problemas de gênero: feminismo e subversão da identidade. Rio de Janeiro: Civilização Brasileira, 2003.

CABRAL, Maria Manuela A. Lacerda. A História como Memória em 'A Costa dos Murmúrios' de Lídia Jorge. Porto: Universidade do Porto, 1996.

'A costa dos murmúrios' de Lídia Jorge: inquietação pós-moderna. Porto: Universidade do Porto, 1997.

CANDIDO, Antônio. A personagem de ficção. São Paulo: Perspectiva, 1987.

CASSIRER, Ernst. Linguagem e mito. 4. ed. São Paulo: Perspectiva, 2000.

CASTELLS, Manuel. O poder da identidade. A era da informação: economia, sociedade e cultura. Trad. Klauss Brandino Gerhardt. São Paulo: Paz e Terra, 1999. v. 2. 
CHEVALIER, Jean; GHEERBRANT, Alain. Dicionário de símbolos: (mitos, sonhos, costumes, gestos, formas, figuras, cores, números). 19. ed. Rio de Janeiro: José Olympio, 2005.

CHIAMPPI, I. O realismo maravilhoso. São Paulo: Perspectiva, 1980.

CLARK, Katerina; HOLQUIST, Michael. Mikhail Bakhtin. Trad. J. Guinsburg. São Paulo: Perspectiva, 1998.

COELHO, Nelly Novaes. A guerra colonial no espaço romanesco. Via Atlântica, ${ }^{\mathrm{o}} 7$, Outubro, 2004.

D'OREY, Stephanie. Interwiew with Lídia Jorge. In: Lídia Jorge: in other words - por outras palavras. Portuguese Literary \& Cultural Studies Subscription. Center for Portuguese Studies and Culture. University of Massachusetts, Dartmouth, 1999.

EAGleton, T. As ilusões do Pós-Modernismo. Trad. Elisabeth Barbosa. Rio de Janeiro: Zahar, 1998.

EDFELDT, Chatarina. Uma história na História: Representações da autoria feminina na História da Literatura Portuguesa do século XX. Montijo: Câmara Municipal do Montijo, 2006.

ELIADE, Mircea. Mito e realidade. 6. ed. São Paulo: Perspectiva, 2004.

. Imagens e símbolos: ensaios sobre o simbolismo mágico-religioso.

Trad. Sonia Cristina Tamer. São Paulo: Martins Fontes, 1991.

História das crenças e das ideias religiosas. Trad. Roberto Cortes de

Lacerda. Rio de Janeiro: Zahar Editores, 1978. v. 1 e v. 2.

Tratado de história das religiões. 2. ed. Trad. Fernando Tomaz e Natália Nunes. São Paulo: Martins Fontes, 2002.

Entrevista com Lídia Jorge. Folha de São Paulo, 05/04/1998.

ERGAS, Yasmine. O sujeito mulher. O feminismo dos anos 1960-1980. In: DUBY, Georges; PERROT, Michelle. História das mulheres no Ocidente. Trad. Alda Maria Durães; Alice Teles; Alberto Couto. Porto: Edições, 1991. O século XX, v.5.

FARACO, Carlos A. Autor e autoria. In: BRAIT, Beth. Bakhtin: conceitos-chave. 4. ed. São Paulo: Contexto, 2007.

FARIA, Nalu. Sexualidade e gênero: uma abordagem feminista. São Paulo: SOF, 1998.

FERREIRA, Ana Paula. Donning the "Gift" of representation: Lídia Jorge's 'A Instrumentalina'. In: Lídia Jorge: in other words - por outras palavras. Portuguese Literary \& Cultural Studies Subscription. Center for Portuguese Studies and Culture. University of Massachusetts, Dartmouth, 1999. 
FERREIRA, Ana Paula. Lidia Jorge's 'A costa dos murmúrios': History and the Postmodern She-Wolf. In: Revista Hispanica Moderna. n. 45, 1992,pp. 268-278.

FONSECA, M. A. Michel Foucault e a constituição do sujeito. São Paulo: EDUC, 1995.

FORSTER, E. M. Aspectos do romance. Trad. Maria Helena Martins. 2 ed. Porto Alegre: Globo, 1998.

FOUCAULT, M. Vigiar e Punir: nascimento da prisão. Petrópolis: Vozes. 2005. O que é um autor? Lisboa: Passagens, 1992.

. O sujeito e o Poder. In: RABINOW, P e DREYFUS, Hubert L. Foucault, Uma Trajetória Filosófica: para além do estruturalismo e da hermenêutica. Trad. Vera Porto Carrero. Rio de Janeiro: Forense Universitária, 1995.

GOMES, Álvaro Cardoso. A voz itinerante: ensaio sobre o romance português contemporâneo. São Paulo: Editora da Universidade de São Paulo, 1993. (Criação \& Crítica; vol. 14).

GONÇALVES, Maria Madalena. Lídia Jorge: a arte de narrar. 'Marido e outros contos'. n. 9, 2000, pp. 123-138.

HALL, Stuart. A identidade cultural na pós-modernidade. Trad. Tomaz Tadeu da Silva e Guacira Lopes Louro. 11. ed. Rio de Janeiro: DP\&A, 2006.

HOLLANDA, Eloisa Buarque de. Tendência e impasses: o feminismo como crítica da cultura. Rio de Janeiro: Rocco, 1994.

HOUAISS, Antônio. Dicionário da Língua Portuguesa. Rio de Janeiro: Objetiva, 2001, p. 2304.

HUTCHEON, Linda. Poética do pós-modernismo: história, teoria, ficção. Trad. Ricardo Cruz. Rio de Janeiro: Imago, 1991.

Uma teoria da paródia. Lisboa: Edições 70, 1989.

JARDINI, Tereza de Jesus Carrera. $O$ Mito em 'O dia dos prodígios' de Lídia Jorge. Tese (Doutorado em Letras). São Paulo: FFLCH-USP, 2000.

JORDÃO, Paula. A Costa dos Murmúrios: Uma Ambiguidade Inesperada. In: Lídia Jorge: in other words - por outras palavras. Portuguese Literary \& Cultural Studies Subscription. Center for Portuguese Studies and Culture. University of Massachusetts Dartmouth, 1999.

Os murmúrios da identidade em dois romance de Lídia Jorge. In: Actas do Quinto Congresso da Associação Interlusitanistas. Coimbra: Oxford, 1998, pp. 857-863. 
JORDÃO, Paula. Echos of Transidentity: The Transmission and Construction of Identity in Two Novels By Lidia Jorge. (tese de doutoramento) University of Utrecht, 2001.

JORGE, Lídia. O romance e o tempo que passa ou a convenção do mundo imaginado. In: Lídia Jorge: in other words - por outras palavras. Portuguese Literary \& Cultural Studies Subscription. Center for Portuguese Studies and Culture. University of Massachusetts, Dartmouth, 1999.

JOSEF, Bella. O resgate da memória na literatura contemporânea. In: Anais do $2^{o}$ congresso da ABRALIC - Literatura e memória cultural. Belo Horizonte: Associação Brasileira de Literatura Comparada, 1991.

KLOBUCKA, Anna. O formato mulher. A emergência da autoria feminina na poesia portuguesa. Coimbra: Angelus Novus, 2009.

LANDOWSKI, Eric. Buscas de identidade, Crises de Alteridade. In: Presenças do Outro. Ensaios de Sociossemiótica. São Paulo: Perspectiva, s.d., pp. 4-29.

LEVI-STRAUSS, Claude. O pensamento selvagem. São Paulo: Nacional, 1976.

Lídia Jorge: vendo a alma por um livro. Entrevista de Carlos Vaz Marques. Revista LER, 2011, pp. 28-86.

LIMA, Isabel Pires de. Palavra e identidade(s) em Lídia Jorge vinte anos de caminho. In: MARGATO, Izabel \& GOMES, Renato Cordeiro. (org.) Literatura/política/cultura. (1994-2004). Belo Horizonte: Editora UFMG, 2005. Vozes e olhares no feminino. Porto: Afrontamento, 2001.

LOURENÇO, Eduardo. Mitologia da saudade: seguido de Portugal como destino. São Paulo: Companhia das Letras, 1999.

. Dez anos de literatura portuguesa (1974-1984): literatura e revolução. In: Revista Colóquio/Letras. Balanço, n. ${ }^{\circ} 78$, Mar. 1984, pp. 7-16.

Casa da Moeda, 1994.

Nós e a Europa ou as duas razões. Lisboa: Imprensa Nacional O labirinto da saudade. 3. ed. Lisboa: Dom Quixote, 1988.

MACEDO, Ana Gabriela (org.) Antologia crítica do feminismo contemporâneo. Lisboa: Cotovia, 2002.

MAGALHÃES, Isabel Alegro de. O sexo dos textos. Lisboa: Caminho, 1995.

Capelas imperfeitas: configurações literárias da identidade portuguesa. In: RAMALHO, Maria Irene. RIBEIRO, Antonio Sousa (Orgs.). Entre ser e estar: raízes, percursos e discursos da identidade. Coimbra: Apontamento, 2001. pp. 307-348. 
MAGALHÃES, Isabel Alegro de. Os véus de Artémis: alguns traços da ficção narrativa de autoria feminina. In: Revista Colóquio/Letras. Ensaio, n. ${ }^{\circ}$ 125/126, Jul. 1992, pp. 151-168.

O tempo das mulheres - A dimensão temporal na escrita feminina contemporânea. Lisboa: Imprensa Nacional Casa da Moeda, 1987.

MARQUES, Maria Isabel Gomes. As cores de Lídia Jorge. Lisboa: Hugin Editores, 2004.

MATOS, Olgária. Desejos de evidência, desejo de vidência: Walter Benjamin. In: $O$ desejo. Org. Adauto Novaes. São Paulo: Companhia das Letras, 1990. pp. 283-305.

MATTOSO, José. História contemporânea de Portugal. Lisboa: Amigos do Livro, 1985, «Estado Novo», Vol. II e «25 de Abril», vol. único.

História de Portugal. Lisboa: Ediclube, 1993, vols. XIII e XIV.

MAXWELL, Kenneth. O império derrotado. São Paulo: Companhia das Letras, 2006.

MEDEIROS, Paulo de. Memória Infinita. In: Lídia Jorge: in other words - por outras palavras. Portuguese Literary \& Cultural Studies Subscription. Center for Portuguese Studies and Culture. University of Massachusetts, Dartmouth, 1999.

MIELIETINSKY, E. M. A poética do mito. Trad. Paulo Bezerra. Rio de Janeiro: Forense-Universitária, 1987.

MOISÉS, Massaud. A Criação Literária: prosa. São Paulo: Cultrix, 1985.

Literatura: mundo e forma. São Paulo: Cultrix / Edusp, 1982.

MOUTINHO, Isabel. Em África não há bruxas: O estranho, o mágico e o pós-colonial em $O$ dia dos prodígios e Vinte e zinco. In: IV CONGRESSO INTERNACIONAL DE LITERATURA DA ASSOCIAÇÃO PORTUGUESA DE LITERATURA COMPARADA. Austrália: La Trobe University, 2001.

MUCHAIL, S. T. O lugar das instituições na sociedade isciplinar. In: RIBEIRO, R. J. (org.). Recordar Foucault: os textos do Colóquio Foucault. São Paulo: Brasiliense, 1985, pp. 196-208.

MUIR, Edwin. A estrutura do romance. Porto Alegre: Globo, s.d.

NUNES, Benedito. O tempo na narrativa. 2. ed. São Paulo: Ática, 1995.

OLIVEIRA, Anabela B. de. O "desentendimento" do narrador na obra de Lídia Jorge. In: Lídia Jorge - Dossier. Letras \& Letras, n. 55, 18 set. 1991.

ORIONE, Eduíno José de Macedo. O romance de Lídia Jorge: História, mito e paródia. Revista Kalíope, São Paulo, ano 5, n. 10, ago/dez. 2009, pp. 80-90. 
OWEN, Hilary. Back to Nietzsche: the making of an intellectual/woman. Lídia Jorge's "A costa dos murmúrios". In: Lídia Jorge: in other words - por outras palavras. Portuguese Literary \& Cultural Studies Subscription. Center for Portuguese Studies and Culture. University of Massachusetts, Dartmouth, 1999.

PERROT, Michelle. As mulheres ou os silêncios da história. Bauru: Edusc, 2005.

PIMENTEL, Irene. Cem anos de vida das mulheres em Portugal. Revista História, $\mathrm{n}^{\circ}$ 34, ano XXIII (III série), Março de 2001, pp. 12-23.

PINTO, Antônio Costa. O fim do império português: a cena internacional, a guerra colonial, e a descolonização, 1961-1975. Lisboa: Livros Horizonte, 2001.

POLLAK, Michel. Memória e identidade social. In: Estudos históricos. Rio de Janeiro: FGV. vol. 5, nº 10, 1992, pp. 200-212.

POUILLON, Jean. O tempo no romance. São Paulo: Cultrix / Edusp, 1974.

QUADROS, Antonio. A ideia de Portugal na literatura portuguesa dos últimos cem anos. Lisboa: Fundação Lusíada, 1989.

RAMALHO, Cristina (org.) Literatura e feminismo: propostas teóricas e reflexões críticas. Rio de Janeiro: Elo, 1999.

RAPUCCI, Cleide Antonia. Mulher e deusa: a construção do feminino em Fireworks de Angela Carter. Maringá: EDUEM, 2011.

REIS, António. Portugal Contemporâneo. Lisboa: Alfa, 1989, Vol. V.

REMÉDIOS, Maria Luíza Ritzel (Org.) O despertar de Eva: gênero e identidade na ficção de língua portuguesa. Porto Alegre: EDIPUCRS, 2000.

RIBEIRO, Margarida Calafate. Uma história de regressos: império, Guerra Colonial e pós-colonialismo. Porto: Afrontamento, 2004.

África no feminino: As mulheres portuguesas e a Guerra Colonial. Revista crítica de ciências sociais, Coimbra, $\mathrm{n}^{\circ}$ 68, pp 7-29, Abril 2004.

RICOEUR, Paul. Tempo e narrativa. Campinas: Papirus, v. 3, 1995.

Santa Terezinha do menino Jesus e da sagrada face. História de uma alma: manuscritos autobiográficos. 30. ed. São Paulo: Paulus, 2013.

SANTANNA, Jaime dos Reis. Literatura e ideologia. São Paulo: Novo Século Literário, 2003.

SANTOS, Boaventura de Sousa. O estado e a sociedade em Portugal (1974-1988). Porto: Afrontamento, 1990. 
SANTOS, Boaventura de Sousa. Onze teses por ocasião de mais uma descoberta de Portugal. In: Pela mão de Alice: o social de o político na pós-modernidade. São Paulo: Cortez, 1995.

colonialismo e inter-identidade. In:

Entre Próspero e Caliban: Colonialismo, pósdiscursos da identidade. Orgs. Maria Irene Ramalho e Antônio Sousa Ribeiro. Porto: Afrontamento, 2002, pp. 23-85.

SANTOS, Carina Faustino. A escrita feminina e a guerra colonial. Lisboa: Vega, 2003.

SANTOS, Maria Irene Ramalho de Sousa. Da história como memória do desejo : «O Cais das Merendas» de Lídia Jorge. In: Revista Colóquio/Letras. Ensaio, n. ${ }^{\circ}$ 109, Maio 1989, pp. 60-68.

SCHOLES, Robert; KELLOG, R.. Trad. Gert Meyer. A natureza da narrativa. São Paulo: McGraw-Hill do Brasil, 1977.

SEIXO, Maria Alzira. Recensão crítica a 'O cais das merendas', de Lídia Jorge. In: Revista Colóquio/Letras. Recensões Críticas, n. ${ }^{\circ}$ 75, Set. 1983, pp. 98-100.

SELIGMANN-SILVA, M. Reflexões sobre a memória, a história e o esquecimento. In: Seligmann-Silva, M. (org.). História, Memória, Literatura. O testemunho na era das catástrofes. (pp. 59-89). Campinas: Editora da UNICAMP, 2003.

SECCO, Lincoln. Trinta anos de Revolução dos Cravos. Revista Adusp, Outubro, 2004.

SILVA, Lígia. (Re)Telling History: Lídia Jorge's "O dia dos prodígios". In: Lídia Jorge: in other words - por outras palavras. Portuguese Literary \& Cultural Studies Subscription. Center for Portuguese Studies and Culture. University of Massachusetts, Dartmouth, 1999.

SILVA, Tomaz Tadeu da. Identidade e diferença: a perspectiva dos estudos culturais. Tomaz Tadeu da Silva (org.) Stuart Hall, Kathryn Woodward. 9. ed. Petrópolis, RJ: Vozes, 2009.

SIMÕES, Maria de Lourdes Netto. Para não dizer que não falei dos cravos: 1960-1990, o contexto histórico-cultural português. In: FUNDAÇÃO CASA DE JORGE AMADO. As razões do imaginário. Salvador: Editus, 1998, anexo 1.

TAVARES, Manuela. Anos 60, os ventos para uma nova vaga dos feminismos não chegam a Portugal. In: Feminismos: percursos e desafios (1947-2007). Rio de Janeiro: Editora Leya, 2011.

TODOROV, Tzvetan. Introdução à literatura fantástica. Trad. Maria Clara Corra Castelo. São Paulo: Perspectiva, 2004.

Vários autores. Guerra Colonial. Edição do Diário de Notícias (Portugal). 
ZIANI, Beth. Tempo de bordar. Revista interdisciplinar de gestão social, set. / dez., 2013, v.2, n.3, pp. 191-203.

ZILLI, Therezinha de Lourdes Coelho. O jardim sem limites, de Lídia Jorge: uma arqueologia da narrativa (tese de doutorado). São Paulo: FFLCH-USP, 2002.

\section{SITES}

GODÊNCIO, Elisangela Fátima Nogueira. A questão da alienação em 'O dia dos prodígios' de Lídia Jorge. 2007. Dissertação (Mestrado em Literatura Portuguesa) Faculdade de Filosofia, Letras e Ciências Humanas, Universidade de São Paulo, São Paulo, 2007. Disponível em: http://www.teses.usp.br/teses/disponiveis/8/8150/tde31102007-152906/ Acesso em: 31 de dezembro de 2013.

KANT, Emmanuel. Crítica da razão pura. Trad. J. Rodrigues de Merege. Créditos da digitalização: Membros do grupo de discussão Acrópolis (Filosofia). Disponível em: http://br.egroups.com/group/acropolis/ Acesso em: 31 de dezembro de 2014.

TEZZA, Cristóvão. A construção das vozes no romance. Texto apresentado no Colóquio Internacional Dialogismo: Cem Anos de Bakhtin (novembro de 1995; Departamento de Linguística da FFLCH/USP.) Publicado em Bakhtin, dialogismo e construção do sentido. Campinas: Editora da Unicamp, 2001; organização de Beth Brait.

Disponível

em http://www.cristovaotezza.com.br/textos/palestras/p_vozesromance.htm Acesso em: 20 de novembro de 2012. 